UNIVERSIDADE DE BRASÍLIA - UnB

INSTITUTO DE CIÊNCIAS SOCIAIS - ICS

CENTRO DE PESQUISA E PÓS-GRADUAÇÃO SOBRE AS AMÉRICAS - CEPPAC PROGRAMA DE PÓS-GRADUAÇÃO EM ESTUDOS COMPARADOS SOBRE AS AMÉRICAS

O EXTERMÍNIO DO OUTRO: A GUERRA CONTRA AS DROGAS NO MÉXICO

Erick Andrés Reyes Trivilino

Brasília, dezembro de 2016. 
UNIVERSIDADE DE BRASÍLIA - UnB

INSTITUTO DE CIÊNCIAS SOCIAIS - ICS

CENTRO DE PESQUISA E PÓS-GRADUAÇÃO SOBRE AS AMÉRICAS - CEPPAC PROGRAMA DE PÓS-GRADUAÇÃO EM ESTUDOS COMPARADOS SOBRE AS AMÉRICAS

\title{
O EXTERMÍNIO DO OUTRO: A GUERRA CONTRA AS DROGAS NO MÉXICO
}

\author{
Erick Andrés Reyes Trivilino
}

Dissertação apresentada ao Centro de Pesquisa e Pós-graduação sobre as Américas como parte dos requisitos para a obtenção do título de Mestre. Orientador: Prof. Dr. Martín-León-Jacques Ibáñez de Novion. 
UNIVERSIDADE DE BRASÍLIA - UnB

INSTITUTO DE CIÊNCIAS SOCIAIS - ICS

CENTRO DE PESQUISA E PÓS-GRADUAÇÃO SOBRE AS AMÉRICAS - CEPPAC PROGRAMA DE PÓS-GRADUAÇÃO EM ESTUDOS COMPARADOS SOBRE AS

AMÉRICAS

Erick Andrés Reyes Trivilino

\section{O EXTERMÍNIO DO OUTRO: A GUERRA CONTRA AS DROGAS NO MÉXICO}

Dissertação apresentada ao Centro de Pesquisa e Pós-graduação sobre as Américas como parte dos requisitos para a obtenção do título de Mestre pela seguinte banca examinadora:

Prof. Dr. Martin-León-Jacques Ibáñez de Novion - Presidente - CEPPAC / UnB

Profa. Dra. Haydée Glória Cruz Caruso - SOL / UnB

Profa. Dra. Rebecca Forattini Altino Machado Lemos Igreja - CEPPAC / UnB

Profa. Dra. Simone Rodrigues Pinto - Suplente - CEPPAC/UnB

Brasília, dezembro de 2016. 


\section{EPÍGRAFE}

"Against stupidity, the very gods themselves contend in vain."

(Friedrich Schiller, The Maid of Orleans, 1801)

“(...) whenever it's a damp, drizzly November in my soul; (...) and especially whenever my hypos get such an upper hand of me, that it requires a strong moral principle to prevent me from deliberately stepping into the street, and methodically knocking people's hats off - then, I account it high time to get to sea as soon as I can. There is nothing surprising in this. If they but knew

it, almost all men in their degree, some time or other, cherish very nearly the same feelings towards the ocean with me.

Why is every robust healthy boy with a robust healthy soul in him, at some time or other crazy to go to sea? Why upon your first voyage as a passenger, did you yourselffeel such a mystical vibration, when first told that you and your ship were now out of sight of land? Why did the old Persians

hold the sea holy?

Surely all this is not without meaning. And still deeper the meaning of that story of Narcissus, who became he could not grasp the tormenting, mild image he saw in the fountain, plunged into it and was drowned. But that same image, we ourselves see in all rivers and oceans. It is the image of the ungraspable phantom of life.

And this is the key to it all."

(Herman Mellvile, Loomings, Moby Dick; or, The Whale, 1851) 


\section{DEDICATÓRIA}

Aos mortos, aos desaparecidos e aos silenciados da injusta guerra Aos que lutam e resistem com a palavra e a força Aos meus pais, à minha irmã, ao meu sobrinho Aos meus amigos 


\section{AGRADECIMENTOS}

O extenso tempo dedicado à elaboração que materializa a presente dissertação não é apenas produto de um esforço pessoal, senão que é a obra conjunta de todas as pessoas que direta ou indiretamente foram parte da minha vida durante os últimos quatro anos. Pessoas que estiveram involucradas no processo de formação profissional e construção do projeto e da dissertação, assim como aquelas que foram parte do meu dia a dia tanto no Brasil como no México.

Porém, é apenas justo começar mencionando o agradecimento profundo que tenho pelo Brasil e pelo povo brasileiro por haver me outorgado a possiblidade de continuar a minha formação profissional neste país tão maravilhoso como grande é seu território. Quero agradecer também à Universidade de Brasília - UnB, ao Centro de Pesquisa e Pós-graduação sobre as Américas CEPPAC e à Coordenação de Aperfeiçoamento de Pessoal de Nível Superior - CAPES pela abertura que mantêm ao receber estudantes do exterior que visam expandir os próprios horizontes humanos e profissionais em um ambiente que, embora por momentos não seja o que foi planejado, incentiva a integração interdisciplinar das distintas áreas do conhecimento e promove a tão necessária rixa e debate político que nos mantem caminhando para o horizonte inalcançável.

Por outro lado, é necessário agradecer à cidade que me acolheu durante quatro anos e que acabou virando parte de mim. Uma cidade planejada e pequena para os parâmetros de alguém que veio da Cidade do México, mas que possui um espirito tão intenso que não é fácil de se encontrar. Brasília é uma cidade que na primeira impressão pode parecer hostil pela frialdade da sua organização e da população, porém, além dessa frialdade ser parte essencial do que faz ela ser o que é, existe também uma beleza imensa na capacidade que essas ruas sem esquinas têm para armazenar lembranças irrenunciáveis que ficarão para sempre na minha memória. Esta cidade te dá a possibilidade de juntar a estética da seca e das chuvas com imagens e momentos que te fazem sentir vivo de novo. Não, Brasília não é uma cidade dócil, e é aí que radica a sua beleza. Asa Norte, Asa Sul, Cruzeiro, Taguatinga, Sobradinho e a Octogonal ficarão para sempre na minha memória pela intensidade dos momentos vividos.

O agradecimento eterno é também para meu orientador, o Prof. Dr. Jacques de Novion, pelo acompanhamento que me deu desde o primeiro momento em que nos encontramos nas 
circunstâncias mais aleatórias possíveis, agradeço a confiança e a certeza que sempre teve de saber que superaria os obstáculos e as dificuldades do caminho. A sua paciência, sinceridade, profissionalismo e dedicação para com os seus alunos fazem que a presente dissertação haja sido materializada e por isso estarei por sempre agradecido. Ao corpo docente e administrativo do CEPPAC pela oportunidade de compartilhar este momento de crescimento pessoal e coletivo, pela sabedoria e pela incessante construção do pensamento crítico. Agradeço especialmente à Profa. Dra. Rebecca Lemos Igreja e à Profa. Dra. Haydée Caruso pela disposição para formar parte da banca examinadora da presente dissertação.

Aos meus pais José Carlos e Rita María, à minha irmã Karla María, ao meu cunhado Carlos e ao meu sobrinho Iñaki Andrés por haverem sido meu porto seguro durante os momentos mais difíceis e por haverem me recebido com os braços abertos cada vez que voltava ao México para passar as férias. Pela confiança que tiveram em mim no momento que decidi partir para o Brasil sem ter a mínima ideia do que pretendia fazer e a certeza que me outorgaram sabendo que eventualmente encontraria a minha razão de haver vindo para este país. Agradeço também pela possibilidade de ser tio pela primeira vez, por sempre vou lembrar do dia que recebi a notícia e, finalmente, por haverem continuado me dando a liberdade que sempre recebi para decidir meu próprio destino sem imposições nem críticas destrutivas, senão com todo o carinho e amor do mundo. Este momento de alegria é também de vocês, obrigado por entender a minha particular forma de ser que, embora seja muito fria, nunca foi carente de amor.

Agradeço a Marcos Magalhães Aguiar por ter me orientado e ajudado na elaboração do projeto que foi aceitado para começar o curso de mestrado em essas incessantes reuniões no Congresso Nacional. Finalmente, para os vizinhos da 308 Norte por haver me integrado na sua comunidade com o maior carinho, fraternidade e respeito. Nunca vou esquecer de nenhum de vocês.

No momento em que a saudade aparece é impossível não lembrar dos amigos que deixei no México quando decidi partir para o Brasil sabendo que eles não entendiam totalmente a minha decisão. Oscar e Ricardo, nunca vou esquecer o momento em que nos despedimos naquela noite do 29 de setembro de 2012 fora da minha casa embaixo da chuva. Foi o momento em que estava me despedindo dos meus irmãos e companheiros da vida sem saber sequer se nos veríamos de novo ou se a amizade sobreviveria à aventura. Pelos bons momentos, por aqueles dias de glória, por aquele momento, Oscar, em que quase te perdi para a morte. Hoje eu apenas agradeço vocês haverem me recebido sempre com a mesma alegria e carinho cada vez que eu voltava para o México para ver que a nossa amizade continuava sendo a mesma, como se eu nunca tivesse partido. Agora eu posso dizer que estou voltando às ruas que nos viram crescer, mais velho, 
mais sábio e mais sincero, mas com o mesmo coração e amor por vocês, pelos momentos que vivemos juntos e por essas lembranças que ainda construiremos. Muitas coisas mudaram nesses últimos quatro anos, mas a amizade é eterna.

Agradeço também a David e Alejandro, amigos da infância, por haverem mantido o contato comigo, pela fidelidade da amizade de 18 anos que temos construído, pelo apoio nos momentos difíceis e pelo futuro. A Cristabell, Vanessa, Diego, Richard, David, Carolina, Luisa, Alda, Raoni, Iuri, Ellen e todos os meus companheiros do CEPPAC pela sabedoria adquirida de vocês e pela amizade que, sabemos, em uma pós-graduação é difícil de criar. Para Alicia Izquierdo da UAM-X por ter sido parte fundamental da minha formação no México e pela ajuda para entrar no CEPPAC. A Maria Fernanda Muñoz e Ximena Molina por terem sido as melhores amigas durante o curso de graduação e pelo apoio durante esses anos no Brasil.

Provavelmente o momento mais difícil é saber que, embora esteja voltando para reencontrar à minha família e grandes amigos, ao mesmo tempo estarei deixando pessoas incríveis e amizades significativas que cresceram durante esses anos no Brasil. É por isso que quero agradecer a Bernardo Azevedo pela sua companhia durante esses anos, por aquelas noites de boteco ou aqueles carnavais quando tentávamos entender e resolver o mundo, pela sua confiança e amizade incondicional. Agradeço também a Wendel pelos bons momentos vividos juntos embora tenham sido poucos; a Everton pelo seu carinho e amizade; a André, Luiz Fernando e Jackson porque juntos fizemos que essas ruas de Brasília virassem nossas; a Ângelo pela sua autenticidade e a sua alegria, coragem e valentia diante da vida; Luigi e Cássio pela sua companhia e amizade durante os difíceis primeiros momentos no Brasil; a Carlos Freire pelo cuidado que teve, pela oportunidade de trabalharmos juntos e por haver estado presente quando foi preciso.

Um agradecimento muito especial para Eduardo Porto por ter me lembrado da importância da sinceridade com si mesmo, pela alegria diante da vida mesmo tendo tudo em contra, pelo carinho e amizade sincera que continua existindo apesar das dificuldades, pelos momentos de adrenalina vividos nas ruas de Brasília, pela euforia das madrugadas juntos, pela confiança e por ter sido um mestre da vida totalmente inesperado. Aprendi muito com você, jamais vou te esquecer e te desejo o melhor na tua vida, você merece isso.

É impossível concluir sem agradecer a aquelas pessoas que ocupam um lugar especial no meu coração, pessoas sem as quais estes anos no Brasil teriam sido muito mais difíceis e que, por consequência, guardo com eles um imenso sentimento de gratidão e uma dívida eterna. Em 
primeiro lugar agradeço a Leonardo Dias por haver sido um amigo incondicional e fiel apesar das diferenças e dos atritos, por haver me ajudado sem pedir nada nos momentos mais difíceis, pela sua paciência e sinceridade e por haver estado presente durante esses anos. Em seguida, agradeço a Pedro Cesar pela sua alegria tão caraterística e por ter me acolhido desde o primeiro momento mesmo sem me conhecer, sempre com a melhor energia e disposição. Finalmente, quero agradecer a Roberto Dias pela sua companhia, amizade, confiança e carinho; pelas insistentes vezes que tentava me ensinar como fazer as coisas à sua maneira mesmo sabendo que isso me deixava irritado e, acima de tudo, por ter virado um irmão.

Não digo adeus, senão até logo. Por enquanto, as alegrias dos bons momentos vividos no Brasil ficarão na minha memória, esperando o momento de construir novas lembranças neste país.

Finalmente, a lição de vida que esta aventura no Brasil me deixou não tem paralelos e é simplesmente a experiência mais forte da minha vida até agora. Foi aqui que perdi a vontade de viver e foi aqui onde consegui recuperá-la, foi um duro caminho de autodescobrimento e de aceitação de saber o que eu sou e de não sentir vergonha. Sei que haverá momentos mais difíceis ainda, mas hoje eu tenho a fortaleza para encarar esses desafios e, se não tiver, agora eu sei que posso confiar nos meus amigos e na minha família e que, no final, tudo pode seguir um caminho diferente que não seja o da morte. Hoje eu sei quem sou e está tudo bem.

A luta continua.

Fascistas não passarão!

Florianópolis, Brasil, 20 de setembro de 2016. 
ADA - Amigos dos Amigos

$\mathrm{AI}$ - Anistia Internacional

AIC - Agencia de Investigación Criminal

AICM - Aeropuerto Internacional de la Ciudad de México

AIU - Asamblea Interuniversitaria

AP - Associated Press

ATF - Bureau of Alcohol, Tobacco, Firearms and Explosives

C-4 - Centro de Control, Comando, Comunicación y Cómputo

CEPPAC - Centro de Pesquisa e Pós-graduação sobre as Américas

CERESO - Centro de Reinserción Social

CIDH - Comissão Interamericana de Direitos Humanos

CJ - Cartel de Juárez

CJNG - Cartel Jalisco Nueva Generación

CMDPDH - Comisión Mexicana de Defensa y Promoción de los Derechos Humanos

CND - Comissão de Narcóticos

CNDH - Comisión Nacional de los Derechos Humanos

CNS - Comisión Nacional de Seguridad

CNTE - Coordinadora Nacional de Trabajadores de la Educación

CROC - Confederación Revolucionaria de Obreros y Campesinos

CS - Cartel de Sinaloa

CTM - Confederación de Trabajadores de México 
CU - Ciudad Universitaria

DEA - Drug Enforcement Agency

DEC - Dominação de Espectro Completo

DFS - Dirección Federal de Seguridad

EAAF - Equipo Argentino de Antropología Forense

EOU - Estadio Olímpico Universitario

ELN - Ejército de Liberación Nacional

E.S.T No 93 - Escuela Secundaria Técnica Número 93

EUA - Estados Unidos de América

EZLN - Ejército Zapatista de Liberación Nacional

FARC-EP - Fuerzas Armadas Revolucionarias de Colombia - Ejército del Pueblo

FFyL - Facultad de Filosofía y Letras

FIFA - Fédération Internationale de Football Association

GAFES - Grupo Aeromóvil de Fuerzas Especiales

GIEI - Grupo Interdisciplinar de Expertos Independientes

HRI - Harm Reduction International

HRW - Human Rights Watch

INE - Instituto Nacional Electoral

IPN - Instituto Politécnico Nacional

ISIS - Islamic State of Iraq and Syria

JIFE - Junta Internacional de Fiscalização de Estupefacientes

MORENA - Movimiento de Regeneración Nacional

MP - Ministerio Público

NMS - Novos Movimentos Sociais 
OEA - Organização dos Estados Americanos

ONU - Organização das Nações Unidas

PAN - Partido Acción Nacional

PBS - Public Broadcasting Service

PCC - Primeiro Comando da Capital

PF - Policía Federal

PFP - Policía Federal Preventiva

PGJ - Procuraduría General de Justicia

PGJEM - Procuraduría General de Justicia del Estado de México

PGR - Procuraduría General de la República

PNR - Partido Nacional Revolucionario

PRD - Partido de la Revolución Democrática

PRODH - Centro de Derechos Humanos Miguel Agustín Pro Juárez.

PRI - Partido Revolucionario Institucional

REDIM - Red por los derechos de la Infancia

SCJN - Suprema Corte de Justicia de la Nación

SEDENA - Secretaría de la Defensa Nacional

SEIDO - Subprocuraduría Especializada en Investigación de Delincuencia Organizada

SEMAR - Secretaría de Marina

SEP - Secretaria de Educación Pública

SFP - Secretaría de la Función Pública

SITATyR - Sindicato Industrial de Trabajadores y Artistas de Televisión y Radio

SNA - Sistema Nacional Anticorrupción

SNTE - Sindicato Nacional de Trabajadores de la Educación 
SSP - Secretaría de Seguridad Pública

SSPDF - Secretaría de Seguridad Pública del Distrito Federal

STFRM - Sindicato de Trabajadores Ferrocarrileros de la República Mexicana

TLCAN - Tratado de Libre Comercio de América del Norte

UAM-X - Universidad Autónoma Metropolitana Unidad Xochimilco

$\mathrm{UI}$ - Universidad Iberoamericana

UNAM - Universidad Nacional Autónoma de México

UnB - Universidade de Brasília

URSS - União de Repúblicas Socialistas Soviéticas 


\section{RESUMO / RESUMEN / ABSTRACT}

A presente dissertação de mestrado analisa a conformação histórica e política do Estado mexicano a partir da construção da percepção do Outro em questão de desejável e indesejável partindo desde o binarismo primordial inaugurado no primeiro contato entre os dois mundos: índio conquistado - europeu conquistador. A evolução, fragmentação e pulverização deste binarismo traz consigo, até a contemporaneidade, a criação de uma infinidade de caraterísticas ou estigmas que categorizarão aos cidadãos em grupos, muitas vezes sobrepostos, de alteridades indesejáveis desde o olhar da hegemonia, seja esta global, continental, nacional, regional ou até mesmo local. A irrupção violenta da guerra contra as drogas no México a partir de 2006 e a escalada de violência generalizada nos leva ao questionamento sobre a eficácia e legitimidade de esta estratégia militarizada diante do aparente ataque e extermínio do qual grupos considerados dentro das categorias “indesejáveis” são vítimas. A análise da construção histórica do desejável e do indesejável, em conjunto com a evolução política do Estado mexicano, os 10 anos de combate militarizado às drogas no México e a análise de três casos particulares de ataques à população civil por parte de agentes do Estado e do narcotráfico, expõe à falácia do discurso beligerante contra as drogas e o posiciona em perspectiva como uma ferramenta de legitimação do extermínio da dissidência, de controle social, de legitimação política, e de perpetuação do narcotráfico como parte fundamental da estrutura estatal mexicana, da economia global e da ordem neoliberal.

Palavras chave: Narcotráfico - México - alteridade - Estado - guerra contra as drogas.

La presente disertación de maestría analiza la conformación histórica y política del Estado mexicano a partir de la construcción de la percepción del Otro en cuestiones de deseable e indeseable partiendo desde el binarismo primordial inaugurado con el primer contacto entre los dos mundos: indio conquistado - europeo conquistador. La evolución, fragmentación y pulverización de este binarismo trae consigo, hasta la época contemporánea, la creación de una infinidad de características o estigmas que categorizarán a los ciudadanos en grupos, muchas veces sobrepuestos, de alteridades indeseables desde la mirada de la hegemonía, sea esta global, continental, nacional, regional o hasta local. La irrupción violenta de la guerra contra las drogas 
en México a partir de 2006 y la escalada de violencia generalizada nos lleva a cuestionarnos la eficacia y legitimidad de esta estrategia militarizada frente a los aparentes ataques y exterminio de los cuales grupos considerados dentro de las categorías "indeseables" son víctimas. El análisis de la construcción histórica de lo deseable y de lo indeseable, en conjunto con la evolución política del Estado mexicano, los 10 años de combate militarizado a las drogas en México y el análisis de tres casos particulares de ataques a la población civil por parte de agentes del Estado y del narcotráfico, expone la falacia del discurso beligerante contra las drogas y lo posiciona en perspectiva como una herramienta de legitimación del exterminio de la disidencia, de control social, de legitimación política y de perpetuación del narcotráfico como parte fundamental de la estructura estatal mexicana, de la economía global y del orden neoliberal.

Palabras clave: Narcotráfico - México - alteridad - Estado - guerra contra las drogas.

This master's dissertation analyzes the historical and political conformation of the Mexican State starting with the construction of the perception of the Other in matters of desirable and undesirable parting from the primordial binary conception inaugurated with the first contact between two worlds: conquered native - European conqueror. The evolution, fragmentation and pulverization of this binary conception brought, until our days, the creation of endless characteristics or social stigmata that will categorize citizens into overlapping groups of undesirable Others from the hegemonic point of view, whether it's global, continental, national, regional or even local. The violent irruption of the war on drugs in Mexico since 2006 and the uncontrolled violence surge make us question the effectiveness and legitimacy of this militarized strategy in sight of the apparent attacks and extermination suffered by these groups considered within the "undesirable" categories. Thus, by analyzing the historical construction of the desirable and undesirable, along with the political evolution of the Mexican State, the 10 year-long war on drugs in México and the analysis of three particular cases of violent attacks against citizens by agents of the State and drug traffickers, this dissertation exposes the fallacy inherent to the belligerent speech against drugs and positions it in perspective as a tool to legitimate the extermination of dissident groups or individuals, of social control, of political legitimation and as a tool to guarantee the perpetuation of drug trafficking as a fundamental building block for Mexican State structure, for global economy and for the neoliberal order.

Key Words: Drug traffic - Mexico - Other - State - war on drugs. 
ÍNDICE

Agradecimentos

Siglas 10

Resumo/Resumen/Abstract. .

Introdução 19

Memorial 20

Marco Teórico - Síntese do argumento 24

Marco Metodológico 30

Resumo Capitular 37

Capítulo I - O Estado mexicano e a questão do Outro 40

1.1 A concepção das alteridades 40

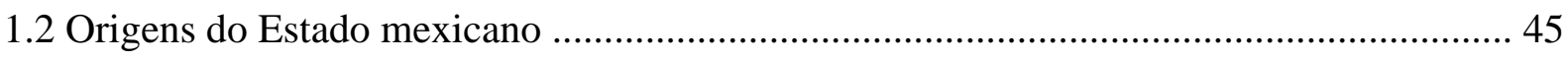

Civilizações originárias, primeiros contatos e conquista ............................................. 45

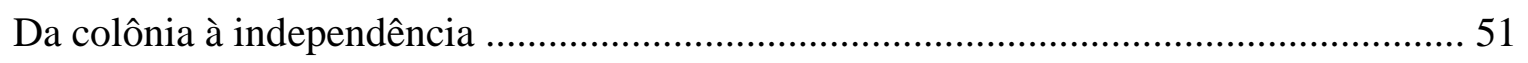

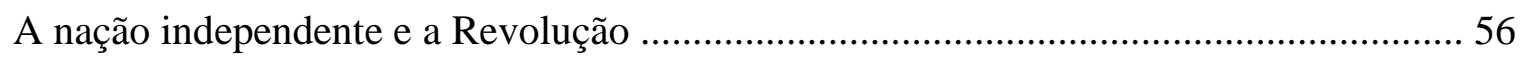

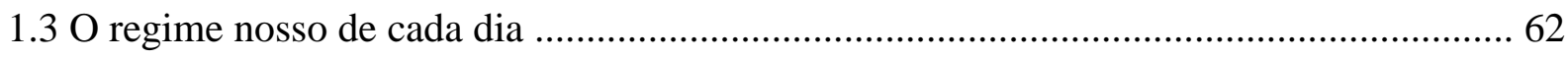

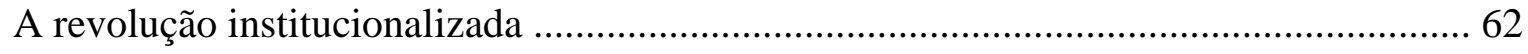

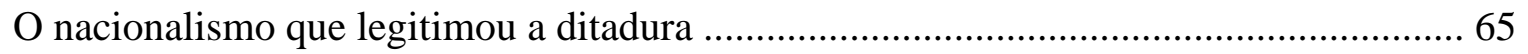

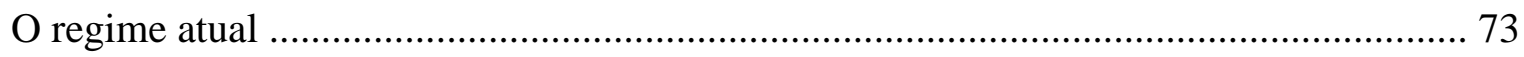

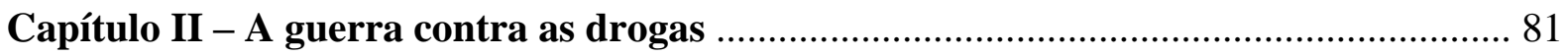

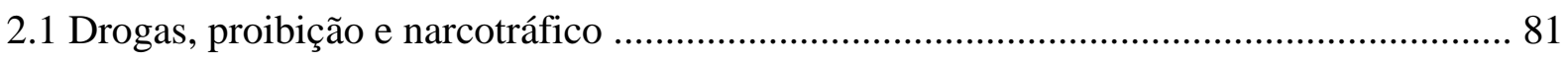

Perspectivas sobre as drogas e a proibição do seu uso ................................................... 81

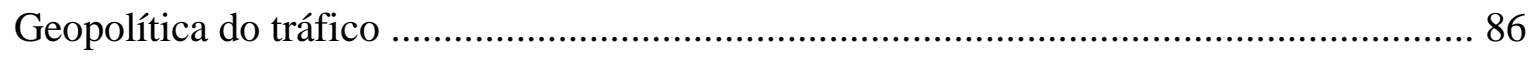

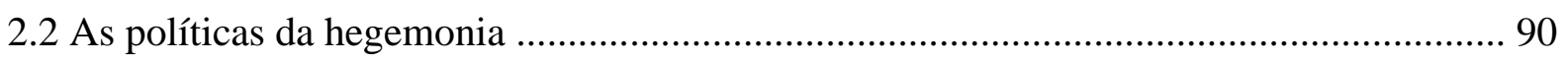

Integração continental, hegemonia e políticas de segurança ......................................... 90 


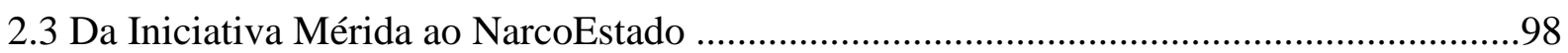

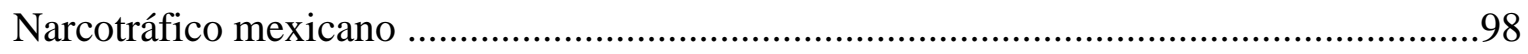

A Iniciativa Mérida e a guerra de Felipe Calderón ....................................................... 104

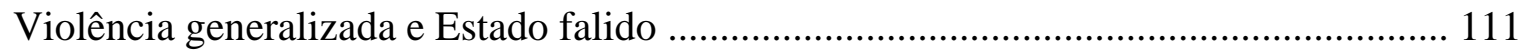

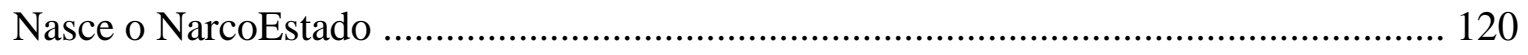

Capítulo III - A população civil e o extermínio legitimado da dissidência ................... 125

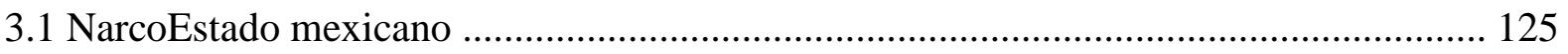

Estado de exceção: a legitimação do extermínio da dissidência ..................................... 133

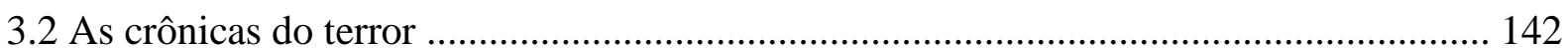

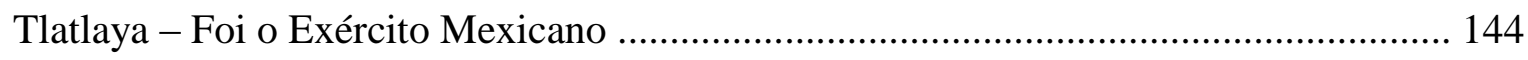

San Fernando - A territorialidade do narcotráfico ...................................................... 153

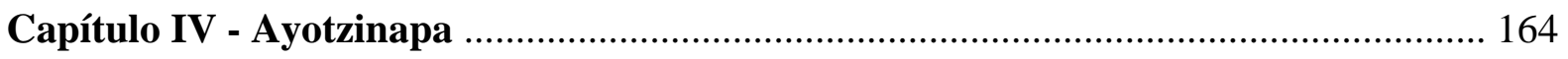

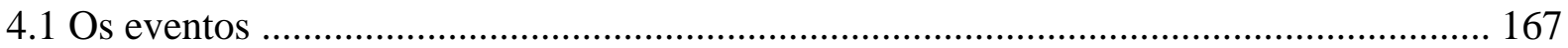

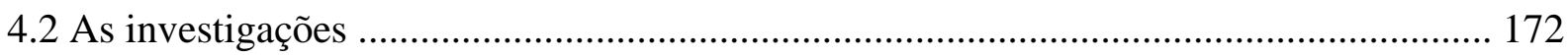

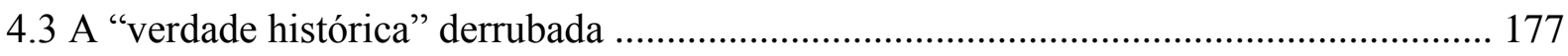

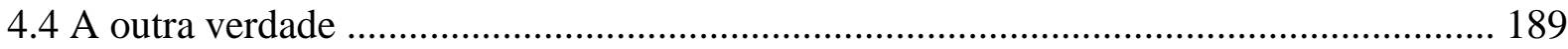

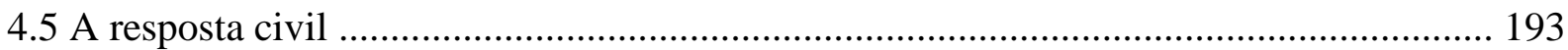

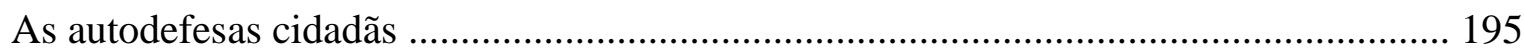

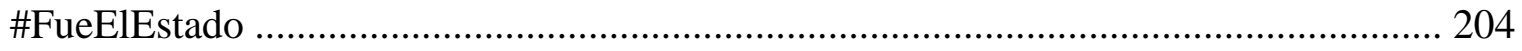

Considerações finais - $\mathbf{O}$ futuro em questão ............................................................. 223

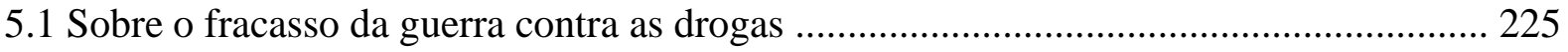

De novas políticas sobre as drogas e os obstáculos no caminho ................................... 232

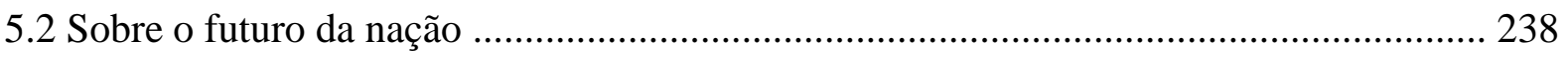

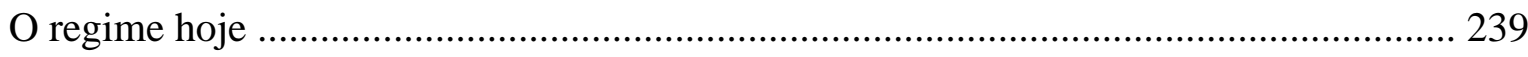

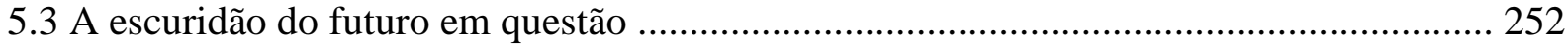


Anexos 255

Bibliografia 261

\section{Sumário}

Figura 1. Evolução do Cartel de Guadalajara 100

Figura 2. Evolução do Cartel del Golfo .100

Imagem 1. Rotas de entrada e trânsito de drogas através do território mexicano 115 


\section{INTRODUÇÃO}

A presente dissertação de mestrado tenta se aproximar, entender e produzir conhecimento em torno da questão do Outro $^{1}$, a sua diferenciação e organização arbitraria em categorias de desejável e indesejável desde os primeiros contatos entre europeus e indígenas, através da evolução histórica da nação mexicana e, principalmente, durante a guerra contra as drogas no país (2006 -?). Através do recorrido em distintas etapas emblemáticas e estratégicas da conformação do Estado mexicano atual, como a conquista, independência, revolução e pósrevolução/modernidade, se faz um mapeamento contextual do processo de construção, diferenciação e fragmentação da concepção das alteridades desde a sua gênese no binômio primordial - índio conquistado/espanhol conquistador - até chegar na atualidade com uma serie de caraterísticas arbitrarias e mutáveis que determinarão o status de desejável e indesejável.

Posteriormente, se analisa a questão das drogas e o combate às mesmas desde uma perspectiva de hegemonia continental e global em conjunto com a análise geopolítica do narcotráfico e a sua vinculação essencial com o sistema neoliberal e, portanto, com o funcionamento do Estado e das suas instituições para posteriormente fazer especial ênfase nas particularidades do Estado mexicano a partir do analisado no primeiro capítulo em matéria de concepção das alteridades e a prática institucional que se deriva do anterior. Portanto, seguindo a linha da prática institucional do Estado em matéria de alteridades desejáveis e indesejáveis no marco da guerra contra as drogas, é necessário aprofundar em três casos emblemáticos de ataque à população civil gerados e justificado a partir do dogma da existência de um Outro exterminável, dialogando, ao mesmo tempo, com a teoria da aplicação de facto do Estado de exceção através dos escritos de Giorgio Agamben (2005) e com dois momentos do Estado mexicano durante a guerra: a etapa de Felipe Calderón (2006-2012) e a etapa de Enrique Peña Nieto (2012-

\footnotetext{
${ }^{1}$ A concepção do Outro explicitada no decorrer da presente dissertação é feita a partir da perspectiva do Estado mexicano histórico e contemporâneo, assim como dos primeiros europeus e da autoridade colonial. Não se pretende silenciar ou excluir arbitrariamente outras formas de representação da alteridade, assim como a diversidade de dissidências e resistências, senão apresentar a construção do Outro a partir da perspectiva estatal.
} 
presente), os quais permitem observar concepções e motivações distintas para a efetivação da Iniciativa Mérida no combate às drogas.

Finalmente, a presente dissertação discute a legitimidade da resposta da população civil diante da deflagração da guerra contra as drogas e os ataques aos cidadãos por parte de agentes do Estado e do narcotráfico, assim como a legitimidade da resposta das forças dentro da lógica de funcionamento do Estado de exceção e a dificuldade para conciliar os termos de legitimidade e legalidade. $\mathrm{O}$ anterior dá passo às considerações finais sobre a natureza da guerra contra as drogas no México, as suas implicações diretas para com a população civil e a essencial vinculação com a questão histórica do Outro na nação mexicana. A conclusão da presente dissertação gira em torno ao futuro em questão e à (re)construção do país a partir da cidadania, o estado atual da União, a relação entre governantes, instituições e cidadãos, as propostas de mudança vindas desde a cidadania e uma série de propostas do próprio autor.

\section{MEMORIAL}

A gênese do tema de pesquisa da presente dissertação e as mudanças que foram acontecendo no caminho encontram-se desde a conclusão do curso de ensino médio na Cidade do México (2006), no processo de formação cientifica e profissional na Universidad Autónoma Metropolitana - Xochimilco - UAM-X e nos dois anos de moradia no Brasil antes de começar formalmente o curso de pós-graduação na Universidade de Brasília.

Existe, claro, um enorme interesse pessoal pelo estudo da conformação histórica e política da nação mexicana, particularmente pelo processo revolucionário, o pensamento nacionalista e o domínio absoluto do Partido Revolucionario Institucional - PRI; nascer e crescer no México atravessando os distintos níveis do sistema educativo mexicano revolucionário e rodeado pela constante presença do nacionalismo institucional do regime, outorga a possibilidade de se posicionar desde uma ponto de vista particular e íntimo em relação ao funcionamento do Estado mexicano experimentado na pele; esta situação outorga a vantagem de ser contemporâneo ao momento histórico de interesse sendo sujeito participe. 
No ano de 2006, nas vésperas da formatura do ensino médio, é possível marcar o acontecimento que definiria o interesse definitivo pelo estudo do Estado mexicano moderno que, até esse momento, representava mais dúvidas e desconhecimento do que certezas; as eleições federais de 2006, que marcaram a chegada antidemocrática ao poder de Felipe Calderón, deixaram à sociedade mexicana polarizada entre "esquerda e direita" e ao PRI derrotado totalmente, assim como a uma nova geração de votantes contemplando a possibilidade de criar um novo sistema político livre do partido da revolução e uma discussão política, por momentos radicalizada e intransigente, mas que pela primeira vez se afastava dos lugares comuns do PRI; era sair desse mundo de fantasia nacionalista no qual fomos educados incessantemente durante 18 anos nas mãos de burocratas disfarçados de educadores no dogmatismo mais pré-histórico imaginável e com incessantes repetições ritualísticas próprias de um autoritarismo militar; inevitável relembrar a formação marcial de toda segunda-feira de manhã sob o frio invernal da Cidade do México para honrar à bandeira e entonar o Hino Nacional Mexicano sabendo, de alguma forma, que esses símbolos estavam sequestrados pelo partido que se apropriou arbitrariamente das cores nacionais.

A enorme oportunidade que a chegada ao poder de Felipe Calderón nos deu, embora haja sido a traição do Partido Acción Nacional - PAN aos ideais democráticos que pretendiam haver representado na vitória de Vicente Fox em 2000, deixou ver por um momento a uma nação polarizada, sim, mas livre das cadeias do pensamento priísta e decidida a lutar por uma nova ideia de nação, seja desde a trincheira da direita conservadora ou da esquerda progressista, mas nunca desde o nacionalismo caduco do PRI. Porém, a possibilidade que a nossa nova geração tinha para pensarmos uma nova nação foi cancelada de golpe em 2006 pelas ações beligerantes de Felipe Calderón ao começar uma guerra contra as drogas que não apenas dirigiria os recursos intelectuais, econômicos e institucionais para o esforço de guerra, senão que provocaria o assassinato sistemático de jovens, estudantes, homens e mulheres pelos próximos 10 anos.

A partir de este momento, a discussão de nação foi cancelada e abriu-se o caminho da guerra e a presença constante da violência na vida cotidiana do país. A possibilidade de soterrar ao PRI para sempre foi barrada e permitiu-se o ressurgimento do partido da revolução que retomaria o poder em 2012. Seis anos de guerra dá tempo para inumeráveis tragédias acontecerem; dá tempo para moldar o pensamento coletivo e individual, girando em torno da violência; clausura toda possibilidade de discussão de outros assuntos; a guerra monopoliza e começa a governar a vida dos cidadãos comuns e o pensamento e produção intelectual da academia; a guerra é 
insidiosa e foi jogada a nós arbitrariamente através da figura de Felipe Calderón em direto atendimento às políticas hegemônicas de segurança internacional.

De esta forma, ao perceber o padrão de extermínio da guerra que é sempre focalizado na periferia e no interior e que segue caraterísticas as quais eu fui formado e criado para conceber como indesejáveis, surgiu o interesse pelo estudo do conceito de Outro, de estigmas e mobilidade social, zonas de exclusão urbanas, falha institucional e criminalização, isto durante o meu curso de graduação na UAM-X sob a orientação da Dra. Sara Makowski Muchnik². Como parte dos requisitos para obter o título em Psicologia Social, foi necessária a elaboração de um projeto de intervenção institucional o qual foi feito na Escuela Secundaria Técinica $N^{\circ}$ 93 “Rosario Castellanos" localizada no sul da Cidade do México em um bairro de classe baixa; o objetivo era encontrar a falha institucional da escola que provocava a desconexão total entre os alunos e as autoridades focando-se na criminalização dos mesmos alunos por estigmas sociais e por práticas estigmatizadas como a pichação, o consumo de drogas e atos de violência entre eles.

Esta intervenção derivou na elaboração da monografia ${ }^{3}$ apresentada para a obtenção do título em Psicologia Social e em uma profunda experiência pessoal e acadêmica que definiria definitivamente o interesse pelo estudo da concepção do Outro. A experiência permitiu observar a falha essencial da Secretaria de Educación Pública - SEP, instituição emblemática do Estado revolucionário mexicano, através de um microcosmos representado pela E.S.T $\mathrm{N}^{\circ}$ 93, as autoridades e os alunos: a criação arbitraria de categorias do desejável e indesejável em um contexto particular e delimitado pela escola que emana diretamente dos preceitos da SEP como macro instituição estatal hegemônica, isto é, a diferenciação do Outro arbitraria não apenas é ditada pelas instituições do próprio Estado, senão que é espalhada e dirigida à população inteira mediante a rede institucional da SEP que funciona como sistema circulatório para disseminar a ideologia do regime.

No entanto, o processo de articulação intelectual dos objetos de estudo da conformação e funcionamento histórico do Estado mexicano, a questão do Outro e a guerra contra as drogas não aconteceria até alguns anos depois. No ano de 2012 embarquei para o Brasil em busca da

\footnotetext{
${ }^{2}$ Dra. Sara Makowski Muchnik: Universidad Autónoma Metropolitana - Departamento de Educación y Comunicación - Área de Investigación: Subjetividad y procesos sociales - Línea de Investigación: Salud mental, procesos, relaciones, redes e intervención. http://sia.xoc.uam.mx/profesor_investigador/resp.php?index=31495

${ }^{3}$ MOLINA HERNÁNDEZ, R.X., REYES TRIVILINO, E.A., 2012. La transgresión a la norma: Violencia, drogas y graffiti en una secundaria pública de la Ciudad de México.: Universidad Autónoma Metropolitana Unidad Xochimilco.
} 
continuação da minha vida acadêmica em um ambiente distante da convulsão que o México vivia nesse momento e que me outorgasse a distância suficiente para colocar em perspectiva os assuntos do país.

A primeira tentativa acadêmica de ingresso ao Centro de Pesquisa e Pós-graduação sobre as Américas - CEPPAC da UnB foi feita visando continuar o projeto feito na graduação em Psicologia Social ao propor fazer uma análise do espaço escolar seguindo a lógica da intervenção na E.S.T. $N^{\circ}$ 93; porém, este projeto não seria mais do que uma reedição previsível de algo já feito anteriormente e incompatível pela diferença originaria entre a gênese da nação brasileira e mexicana. A intenção de estudo, portanto, focou-se em um espectro mais amplo: o estudo do Outro; com isto ainda faltaria delimitar o projeto sem cair na mesmice do espaço escolar e outorga-lhe qualidade histórica e política para dimensionar a magnitude da questão do Outro que poderia se perder ou diluir na delimitação espacial e temporal de uma escola.

Para isto se fez o recurso ao interesse pelo estudo da conformação histórica e política da nação, escolhendo o momento histórico que deu origem direto ao regime no qual nasci e cresci: a Revolução Mexicana. A questão do Outro seria delimitada ao estudo da situação do índio como sujeito histórico no México a uma ideologia nacionalista que o reivindicava e soterrava ao mesmo tempo. Porém, embora seja um tema sumamente rico e interessante, é também um tema já visitado amplamente por eminencias intelectuais; não é dizer que já foi dito tudo o que pode se dizer do tema, senão que era momento de aproveitar a oportunidade de se aproximar da questão do Outro e da nação mexicana não apenas desde a sua conformação, senão desde o que está acontecendo com nós nesse momento. Isto é retomar a discussão sobre a nação que queremos, discussão que nos foi arrebatada em 2006 e que hoje podemos recomeçá-la a partir do próprio evento que nos privou dessa oportunidade: o início da guerra contra as drogas. Esta revelação, por chamá-la de alguma forma, veio durante uma estadia de férias no México desde setembro de 2014 até janeiro de 2015; esses meses coincidiram com o sumiço de 43 estudantes normalistas da Escuela Normal Rural "Raúl Isidro Burgos" de Ayotzinapa, caso que será analisado na presente dissertação, e a minha participação direta nas mobilizações massivas da sociedade mexicana assim como a brutal repressão da que fomos vítimas por parte das forças de segurança; de alguma forma e assumindo esse pecado de omissão, foi só nesse momento que compreendi a dimensão da crise.

Dessa forma foi feita a articulação da conformação histórica da nação mexicana desde a perspectiva da questão do Outro e a irrupção da guerra contra as drogas nas nossas vidas; não apenas o fato de haver crescido e haver sido formado no nacionalismo do regime foi 
determinante, senão também o foi haver vivido o processo eleitoral de 2006, o roubo da ilusão de discutir uma nova nação pela guerra de Felipe Calderón e haver sido testemunha vivencial da invasão da violência que permeia tudo e se apropria de todos os aspectos da vida cotidiana de uma nação durante uma década da minha vida; nessa época tinha 18 anos de idade, hoje tenho 28 e é difícil acreditar que só agora estamos começando a discussão que nos foi arrebatada em 2006.

Portanto, considero uma obrigação ética, moral e profissional, antes que cidadã, da academia aprofundar na questão do Outro desde a lente da guerra contra as drogas e a conformação histórica da nação mexicana desde as suas origens e desde qualquer posição e perspectiva de análise; isto é atualizar as pesquisas, os métodos e a compreensão e aceitação da academia hierarquizada da existência decidida de uma nova geração de pesquisadores que se afastam dos modelos teóricos e metodológicos tradicionais; é também trazer elementos contemporâneos à discussão e às salas de aula; mostrar a real importância, atualidade e intensidade da crise humanitária que o México está atravessando, de mãos dadas com o restante do mundo, e não deixa-la como um fenômeno isolado, minimizado e anestesiado pela distância para não ser cumplice silencioso e aliado por omissão da pior crise da história do país.

MARCO TEÓRICO - SÍNTESE DO ARGUMENTO

$\mathrm{O}$ argumento da presente dissertação se sustenta em dois pilares analíticos principais: 1) o narcotráfico e as políticas de combate ao mesmo produzidas desde a hegemonia; e 2) a construção da concepção do Outro no decorrer da história do Estado mexicano. O diálogo entre ambos permite explorar a temática do extermínio deliberado de grupos dissidentes realizado extraoficialmente através da implementação de políticas internacionais de intervenção em matéria de segurança global e continental em conjunto com as projeções de segurança do Estado-nação em assuntos internos. Isto é, a partir de uma política internacional produzida desde a hegemonia, se outorgam e facilitam as armas de legitimação e o próprio armamento bélico para que, dentro de um território particular, os governos em questão possam controlar ou exterminar grupos que ameaçam a estabilidade do próprio governo local ou nacional e dos 
interesses hegemônicos das potências centrais sob o pretexto do legítimo combate às drogas, ao narcotráfico e ao crime organizado.

Porém, embora possa se falar de um padrão generalizado de definição de grupos dissidentes sujeitos ao extermínio desde a ótica hegemônica do combate ao narcoterrorismo, as particularidades históricas de construção de alteridades indesejáveis dos territórios em questão possuem peso específico na forma na qual o Estado nacional e as forças de segurança planejarão e executarão a "guerra" nos territórios escolhidos, assim como na legitimação por parte da própria sociedade civil que receberão ao atingir principalmente aos grupos que essa própria sociedade tem construído como indesejáveis ao longo da história. $\mathrm{O}$ anterior faz referência à construção do Outro desejável e indesejável, assim como a atribuição de estigmas sociais a grupos específicos, como um fenômeno eminentemente comandado pelos grupos hegemônicos em distintas escalas territoriais e distintos momentos históricos que mantêm uma linha em comum, já que estas produções da diferença não são isoladas uma de outra nas distintas etapas históricas, senão que a essência primordial, com as mutações ocasionais, se mantém presente ao longo do tempo.

Portanto, a presente dissertação utiliza o conceito de Outro (ou alteridade) concebendo-o a partir da diferenciação instintiva de autoafirmação e reconhecimento da própria existência, a diferenciação primordial do resto do universo ou do que - não sou eu -. Este conceito é aplicável ao processo de autoafirmação das sociedades humanas e existe em direta vinculação com as origens do Estado-nação e das ideologias nacionalistas nas suas distintas fases históricas. Da utilização de este conceito se desprendem três questões principais: 1) a contextualização para o caso mexicano; 2) as origens das matizes na concepção negativa ou ameaçadora do Outro a partir da sua produção desde a hegemonia particular no caso mexicano; e 3) a sua inserção, manutenção, com as devidas mutações contextuais, e o seu uso político tanto no pensamento coletivo da sociedade mexicana como nos discursos oficiais e nas políticas sociais, econômicas e de segurança da colônia novo-hispana e posteriormente do Estado mexicano.

A primeira questão, essencial na presente dissertação, se resolve mediante o reconhecimento de um binômio primordial e paradigmático de diferenciação do Outro na história mexicana e continental: o encontro de dois mundos entre o Outro europeu e o Outro indígena. Este conceito é explorado por Tzvetan Todorov (2003) e estabelece à chegada dos europeus na América como um ponto decisivo, livre de arbitrariedades, na história do continente e do globo. A diferenciação do Outro no continente americano teve consequências tão profundas que 
continuam definindo a nossa autoafirmação e percepção do Outro até mesmo em questões nacionais e continentais: nós, os periféricos, os colonizados; eles, os centrais, os conquistadores.

A adequação ao caso mexicano adquire matizes particulares ao considerarmos a existência prévia de uma ampla gama de civilizações desenvolvidas e altamente especializadas no atual território mexicano que, em conjunto com o Império Inca no atual Peru, representavam focos civilizatórios avançados e alheios às matrizes civilizatórias europeias ou asiáticas historicamente hegemônicas e consideradas, por elas mesmas, na vanguarda da espécie humana. Portanto, estaríamos falando de uma multiplicidade de grupos populacionais, cosmovisões, formas de organização política, econômica e militar e até mesmo racial prévia à invasão europeia como afirma Charles Mann (2002); isto é, muitos Outros já definidos e diferenciados, mas inter-relacionados, que iriam encontrar um Outro totalmente desconhecido. Se juntarmos o fator das diferenças de cosmovisões e formas de entender o mundo dos grupos indígenas e a arrogância da suposta superioridade divina que a vitória católica sobre os mouros aparentemente outorgava aos invasores europeus, com a variável da superioridade armamentista dos espanhóis, a diferenciação do Outro seria severamente assimétrica e marcada por um sentimento de superioridade natural entre europeu e índio, visível nos relatos de Cristóvão Colombo nos escritos de Todorov (2003), ou até mesmo no relato do "defensor do índio" Bartolomé de Las Casas (2005).

O anterior define a segunda questão teórica do uso do conceito de Outro na presente dissertação: a diferenciação marcadamente assimétrica consagrada no binômio primordial Índio conquistado - europeu conquistador.

Finalmente, a terceira questão sobre a inserção e perpetuação de este binômio paradigmático de definição do Outro no pensamento da população mexicana e no agir do Estado mexicano se considera a partir de Pierre Bourdieu (2002) e a análise da reprodução através das gerações do que é considerado desejável e indesejável definido a partir de fatores socioeconômicos, de mobilidade social e raciais particulares a cada momento histórico mas que mantêm conexão com o momento originário da diferenciação.

É importante dimensionar esta produção da diferença como um fenômeno que acontece naturalmente na psique humana como ferramenta básica de auto reconhecimento diante do universo já que se reconhecer como um $e u$ diante de um universo que não sou $e u$ é uma ruptura primordial que produz angustia e dor e dá lugar a uma serie de binarismos fundamentais (i.e., se $e u$ sou a segurança do meu próprio ser, o restante que não sou $e u$ é hostil), é uma ruptura 
considerada o momento fundacional da psique humana e da conformação do id ,ego e superego na teoria psicanalítica de Sigmund Freud e Jacques Lacan. No entanto, e mais importante ainda, é dimensionar também o uso político que se dá a esta ferramenta básica da psique humana desde o primordial, como a conformação das primeiras sociedades humanas, até o perverso, como o uso do terror provocado pelo que é selvagem, profano ou apenas desconhecido para organizar e manter, por exemplo, a ordem colonial, estabelecer uma ideologia nacionalista com um grupo racial especifico como núcleo ou até mesmo justificar o genocídio de grupos humanos que possuem uma religião, cor de pele ou origem étnica distinta à do poder hegemônico. Portanto, a presente dissertação se orienta seguindo a premissa da definição do desejável e indesejável a partir de um binômio primordial seminatural apropriado, redefinido e perpetuado pelas hegemonias de cada momento histórico, neste caso, do México.

Em seguida, a questão teórica da hegemonia se fundamenta no exposto por Jacques de Novion (2009) na sua tese doutoral na qual entende este conceito a partir da dimensão geopolítica essencial das ideias de dominação do poder político, dos territórios, das estruturas econômicas e da supremacia militar, mas também da dominação das mentes, aspecto central para a presente dissertação e parte do que considera como a multidimensionalidade da hegemonia (p. 40). O autor articula a ideia a partir do continente americano e da evolução hegemônica dos Estados Unidos de América desde a sua definição interna como nação, o processo de expansão territorial, definição de fronteiras, expansão hegemônica próxima e expansão hegemônica plus ultra. Estabelece que cada etapa do processo de avanço hegemônico dos Estados Unidos foi acompanhado de um binômio de integração-segurança particular a cada época que, por um lado, oferecia unilateralmente, desde a bilateralidade ou multilateralidade, a integração econômica da região ou, mediante a coerção e a asfixia, obrigava à integração econômica da região. Por outro lado e de maneira simultânea, a doutrina de segurança combatia, ou relegava o combate a um segundo ator, aos inimigos do projeto hegemônico ao mesmo tempo que estabelecia a sua supremacia militar.

Essa estrutura hegemônica estabelecida pelos Estados Unidos é de suma importância para a presente dissertação para a elaboração da análise sobre o narcotráfico e a guerra contra as drogas como discurso hegemônico legitimador do extermínio de alteridades indesejáveis definidas através de um padrão pseudouniversal. Porém, essa mesma estrutura, ao ser geopolítica essencialmente, é aplicável em distintas escalas territoriais para entender o funcionamento das hegemonias regionais ou locais que darão a sua própria interpretação, definida pela concepção 
histórica e construção das alteridades nesse território particular, à guerra contra as drogas e ao extermínio extraoficial que se estabelece.

Para o anterior, o autor considera central na manutenção da hegemonia o conceito de Dominação de Espectro Completo, conceito articulado em torno da cooptação política das elites ou dos governos locais, do estabelecimento de relações econômicas para favorecer a exploração de recursos e a circulação da mercadoria, a presença e ação militar contra a dissidência e a conquista das mentes, ou uma espécie de domínio psicológico das populações em questão. $\mathrm{O}$ anterior será utilizado na presente dissertação para dialogar com a estruturação histórica do PRI como força hegemônica nacional em conjunto com o surgimento do narcotráfico como segunda força hegemônica e as atitudes mantidas para com as alteridades dissidentes ou indesejáveis produto da construção e manutenção do Outro produzida desde às distintas hegemonias.

Para dar sentido teórico à análise do agir do Estado e do narcotráfico no contexto mexicano contemporâneo, considerando a guerra contra as drogas e a sua origem desde uma hegemonia externa e superior ao Estado mexicano e tendo à sociedade civil no geral como centro da análise, é necessário utilizar o conceito de Estado de exceção a partir da visão de Giorgio Agamben (2005); isto é um estado de suspensão de garantias individuais estabelecido de facto pelo governo sem a necessidade de realizar o ritual de procedimentos constitucionalmente estabelecidos para suspender garantias temporalmente em um território especifico. Segundo o teorizado por Agamben, e sob a premissa de que "a necessidade não tem lei" (p. 24), o Estado denomina arbitrariamente a necessidade que o obriga criar uma bolha legaloide de exceção da lei, sem recorrer a lei nenhuma ao passar por encima do estabelecido constitucionalmente, para de esta forma agir contra os indivíduos ou grupos que considera uma ameaça à estabilidade do próprio Estado. Agamben considera isto um paradigma dos governos contemporâneos (AGAMBEN: 2005, p. 2) mais do que uma excepcionalidade.

De esta forma e mediante o discurso da securitização, da paz, do combate ao terror e ao narcotráfico, pela democracia, contra a corrupção ou pela liberdade, os governos legitimam por si mesmos, e com a anuência da população que se sente agraciada por esse discurso, a intervenção armada contra grupos dissidentes passando por cima do Estado de direito enquanto a população civil entrega liberdades e direitos em troca da segurança armamentista.

O ponto anterior, ao representar a lógica que guia o agir do Estado no contexto de luta internacional contra as drogas e luta interna e extraoficial contra as dissidências, abre a questão da resposta cidadã e o que o próprio Agamben considera como a contradição da ilegalidade do 
direito à resistência e o paradoxo legal e constitucional que a própria existência dos mecanismos legais para estabelecer um Estado de exceção representa. Isto será utilizado para aproximar-se teoricamente da situação complexa que se criou no Estado de Michoacán com a aparição de grupos de autodefesa cidadã, grupos de cidadãos armados para combater tanto às forças militares e federais como aos agentes do narcotráfico. A aparição destes grupos na equação provocou um desequilíbrio nas relações de poder estabelecidas entre o Estado mexicano e os narcotraficantes e ameaçou o monopólio da violência de ambos.

O direito à resistência ou à rebelião por parte dos grupos civis alvo das políticas internacionais contra as drogas e o extermínio de categorias inteiras de cidadãos implícito nessas políticas se observa, por outro lado, através da lente de María da Glória Gohn (2000) e a sua teoria sobre os Novos Movimentos Sociais - NMS. A autora os caracteriza por serem alheios ao espectro político tradicional de esquerda ou direita, e os respectivos matizes, se afastam da visão marxista estruturalista de classes e da perspectiva economicista do aparelho de produção e, ao mesmo tempo, se afastam de uma visão reducionista capitalista do indivíduo e reconhecem à coletividade como um ator social.

Estes NMS possuem também a caraterística da negativa total de colaboração com a estrutura política tradicional, a sua conformação como partido político ou a própria interação com algum partido, isto sendo um reflexo do rompimento entre a classe política e a cidadania sintomática de sistemas políticos excludentes e oligárquicos. Por outra parte, os NMS pelas características mencionadas e pelo fato de considerar à coletividade como ator social, são a reivindicação de categorias inteiras de alteridades indesejáveis definidas arbitrariamente ao estarem organizados longe de concepções de classe ou individualistas. Estes movimentos não pretendem quebrar ao Estado senão que agem dentro das regras estabelecidas e se apropriam de conceitos, categorias ou estigmas considerados tabu e lhes outorgam uma nova dimensão de significados e favorecem a emergência de novas formas de definição e autoafirmação diante do Outro sem cair novamente no perigoso e depredador binarismo do desejável e indesejável. 


\section{MARCO METODOLÓGICO}

A presente dissertação se serve primordialmente de autores, escritos, teorias e publicações tanto cientificas como governamentais elaboradas a partir da realidade latino-americana e particularmente mexicana, isto desde uma perspectiva tanto histórica como contemporânea. A questão da produção de conhecimento autêntico desde esta parcela do continente continua sendo e será uma espécie de tabu pela pretendida carência filosófica primordial de um continente criado a partir da colonização europeia e da importação/imposição das suas formas de perceber, entender e explicar o mundo.

Existem, e sempre foi assim, distintas e variadas formas de tentar dar uma explicação ao universo, é a força primordial que impulsiona ao pensamento humano: a necessidade de responder e entender o que está acontecendo ao nosso redor. Desde a posição de Leopoldo ZEA (1976), a história é, em parte, o que nos dá sentido como espécie a partir da sua tríplice composição: passado, presente e futuro ao homem ser "[...] o há sido, o que é e o que será" (p. 17). O continente americano, aponta o autor, não está excluído de esta tríplice dialética entre presente, passado e futuro e o lugar desde o qual as distintas culturas ou povos pensarão seu universo. O continente americano pré-data à invasão europeia, mas ao mesmo tempo é inegável a transformação profunda que aconteceu desde o primeiro contato com os europeus e a posterior evolução já como continente emancipado embora em direta relação de centro-periferia com Europa, em um primeiro momento, e com os Estados Unidos posteriormente.

Guillermo Bonfil Batalla (1990) aprofunda nessa questão ao se referir à imposição do projeto da "nação imaginada" pelo pensamento ocidental mexicano em detrimento da "profundidade da nação" representada pelas civilizações pré-existentes no território e que já contavam com cosmovisões elaboradas e formas de organização civilizatórias que foram esmagadas pela imposição europeia e que até hoje representa a essência da crise civilizatória do país. Para o autor, a solução ou tentativa de solução não se encontra na volta fanática às "nossas raízes" préhispânicas partindo desde a obviedade de que não são mais - nossas -, sendo que muitos de nós fomos educados e criados a partir do modelo ocidental de país e com certos resquícios das culturas pré-hispânicas reinterpretadas pelo nacionalismo do regime priísta. Porém, a tentativa, segundo Bonfil Batalla (1990, p. 237), deve ser feita a partir da aceitação e reconhecimento da existência e destruição do "México profundo" e a sua persistência em parcelas da sociedade 
consideradas marginais e excluídas em conjunto com a integração plural do projeto do "México imaginário", o qual, afirma o autor, não é totalmente errado e querer excluí-lo seria voltar ao fanatismo cego e da nostalgia por um mundo que não conhecemos nem conheceremos.

Eis a questão de pensar ao continente e aos países que nele se localizam a partir do reconhecimento das nossas duas matrizes de construção de pensamento: tanto a ocidentaleuropeia como a pré-hispânica que, no final, dão origem a um sincretismo único para o continente e com as particularidades de cada região geográfica - nacional.

Portanto, e para efeitos da presente dissertação, a eleição de autores e teorias maioritariamente latino-americanos, assim como o labor hemerográfico em publicações da região, se sustenta na visão privilegiada e particular do continente para o continente mesmo e do México para si mesmo. $\mathrm{O}$ anterior não significa ignorar a inserção do continente nem do país no sistemamundo, assim como tampouco seria demonstrar desdém arbitrário ao pensamento ocidentaleuropeu se entendermos ao pensamento latino-americano como alimentado, em parte, de ocidente. Por sua vez, ao ser uma investigação sobre o agir do Estado mexicano em contextos particulares, considera-se vital contar com duas fontes de informação oficial: a) do próprio Estado mexicano; e b) de fontes independentes tanto nacionais como supranacionais representadas por organismos autônomos (GIEI e centros de direitos humanos nacionais), semiautônomos (EAAF, organizado pela OEA) e a própria ONU. De esta maneira é possível obter uma visão tanto interna como externa sem se comprometer nem submeter à "tirania do oficial" e, ao mesmo tempo, manter as fontes de informação dentro de uma perspectiva latinoamericana.

Por outro lado, a questão do narcotráfico, embora seja um fenômeno de proporções geopolíticas localizáveis no nível analítico mundial, pode ser sim analisado desde uma perspectiva latinoamericana ao ser este fenômeno essencialmente uma forma de organização pregada no nível analítico do local e em estreita relação com a história sociopolítica e econômica de uma nação assim com as suas próprias caraterísticas geográfico-territoriais. Isto é, o narcotráfico pode ser entendido como uma única empresa capitalista neoliberal transnacional, desde uma perspectiva macro, até a sua divisão em narcotráfico colombiano, mexicano, etc. desde um ponto de vista mais próxima do nível analítico tradicional do Estado-nação, até a sua própria fragmentação regional e local em distintos carteis e células de funcionamento; todo o anterior sem esquecer de mencionar a parcela composta pelos consumidores considerados, principalmente mas não exclusivamente, no nível mundial como os países centrais ou hegemônicos do sistema-mundo, ou mais particularmente cada caso por separado focando nos Estados Unidos, ou até mesmo a 
própria existência de elites nacionais (de novo, não exclusivamente) sejam de países periféricos ou centrais que compõem o grosso da demanda de drogas.

A análise do narcotráfico como um assunto do México, é claro, não pode ignorar a dimensão global do tráfico de drogas, porém, visualizar e se aproximar de este fenômeno desde a experiência particular do México, da sua economia, cultura e principalmente dos cidadãos que somos, em primeiro lugar e decididamente, os que experimentamos cotidianamente esta situação e isto, por si mesmo, nos legitima e nos transforma em corpos carregados de marcas e traumas resultantes dessa realidade e de seus impactos efetivos na vida, um conhecimento empírico imposto, muitas vezes, por projetos e políticas elaboradas por membros da própria academia. Este conhecimento empírico, consciente ou inconsciente, vai além de qualquer opinião ou posicionamento academicista ou cientificista. Isto representa uma oportunidade imensa para aqueles que se encontram distantes do que nós vivemos e queiram ter, nem que seja, uma pequena ideia do impacto que a guerra contra o narcotráfico tem sobre nós após 10 anos da sua deflagração.

Portanto, através de um enfoque qualitativo, a presente pesquisa segue três formas de ação principais: 1) a análise histórica da construção e fragmentação do conceito do Outro no México desde o primeiro contato com os europeus até os nossos dias; 2) a análise histórica-geopolítica do uso e tráfico de drogas em conjunto com a investigação hemerográfica e documental oficial do agir dos Estados, principalmente o mexicano, em torno de este fenômeno; e 3) a investigação e análise hemerográfica e documental tanto oficial como independente das consequências para a população civil que o combate armado ao narcotráfico trouxe consigo desde a premissa construída ao longo dos primeiros capítulos: a existência e categorização intencional de alteridades indesejáveis.

\section{A construção histórica do conceito do Outro no México}

Para a elaboração do capítulo que aprofunda na concepção das alteridades no México, utilizouse uma perspectiva histórica documental em conjunto com a análise teórica do conceito do Outro desde Pierre Bourdieu (2000,2002) e Tzvetan Todorov (2003) como eixos teóricos tradicionais em diálogo com Guillermo Bonfil Batalla (1990) e Roger Bartra $(2013,2014)$ como representantes do pensamento latino-americano. Para o anterior, a análise se dividiu em três momentos centrais da história do México: a) época pré-hispânica, conquista e colônia; b) da independência à revolução; e c) origens do PRI e a contemporaneidade. Cada subdivisão 
apresenta a evolução do grande conceito do Outro acompanhado pelas particularidades do contexto em questão sustentado por teorias e escritos particulares a cada época para assim chegar à conclusão do primeiro capítulo que estabelece as bases e antecedentes suficientes para pensar ao Estado mexicano atual em paralelo com a introdução da variável do narcotráfico. A particularidade e caraterística metodológica central do presente capítulo é o uso de distintos espaços temporais da cronologia histórica do Estado mexicano delimitados e determinados pela análise do conceito do Outro o qual, pela qualidade histórica do capítulo e a presença de um conceito teórico que parte desde a subjetividade inerente dos sujeitos e grupos, requer obrigatoriamente do uso de uma estrutura estritamente destinada a evitar o que Quentin Skinner (2002) denomina como "mitologia da coerência e mitologia do paroquialismo" (Kunhavalik, 2009; p. 24); estes erros ameaçam a própria imparcialidade pretendida em uma análise histórica conceitual com a contaminação da própria perspectiva anacrônica do pesquisador na sua concepção de um evento ou pensamento passado e, ao mesmo tempo, representa a suposição inocente da existência de coerência no discurso e pensamento humano; isto é a obrigação de evitar " [...] fazer leitura de obras do passado como se elas existisse de forma independente do contexto em que foram produzidas" (KUNHAVALIK: 2009, p. 25).

O mesmo Skinner (2002, p. 1) adverte sobre o perigo do dogma empiricista da construção de estruturas de conhecimento estritamente fatual fundado em estruturas que pretendemos sejam independentes do nosso juízo. Isto significaria interpretar textos e pensamentos esboçados em épocas passadas erroneamente sob a suposição de que no autor ou sociedade em questão, e no contexto histórico no qual se desenvolveram, existia uma clarividência divina e uma omnisciência invejável que permitia entender com clareza absolutamente tudo o que estava acontecendo em torno do autor e da sociedade da época. A história do pensamento da humanidade sempre girou, gira e girará em torno de uma questão primordial: "o que está acontecendo?".

Isto significa, seguindo paralelamente com o pensamento de Skinner (2002), que nunca houve nem, por enquanto, haverá acesso à informação absoluta e fatual que esclareça o "que acontece com nós", senão que hão apenas tentativas de aproximação e de interpretação dos fatos, tentativa sempre atravessada por e vista desde o olho do observador na constante luta humana de se adentrar no metafórico oceano do conhecimento, imagem descrita por Herman Melville no primeiro capítulo de Moby Dick; no desespero narcisista de projetar sobre o passado a nossa imagem e experiências pessoais próprias do contexto em que crescemos e vivemos, terminamos por nos jogar na agua tentando agarrar o nosso próprio reflexo, insuportável e doloroso, sendo 
que ele é apenas uma ilusão, a "imagem do insondável fantasma da vida”. A projeção de nós mesmos em acontecimentos históricos é inevitável e entender o mecanismo de função, a sua distinção e entendimento como parte da análise, mas não como elemento determinante, é a chave de tudo. A presente dissertação não escapa dessa visão da história.

\section{Uso de drogas e combate às mesmas}

Para se aproximar da temática do narcotráfico e do uso das drogas é preciso se posicionar em e se valer do campo da geopolítica para entender e analisar a dimensão que este fenômeno tem. A análise geopolítica do narcotráfico é uma disciplina relativamente jovem e em construção. É diretamente decorrente da passagem entre conflitos que aconteceu com o final da Guerra Fria e a queda da União Soviética que deu origem a uma nova ordem mundial e a novas ideias e políticas de segurança e hegemonia (LABROUSSE: 2006) das quais o combate ao narcoterrorismo faz parte fundamental.

O narcotráfico é um fenômeno com infinidade de manifestações em diversos planos da existência desde o social, o econômico, até o religioso. Porém, a sua interação e integração nos sistemas políticos contemporâneos desde a sua acepção como um negócio essencialmente neoliberal e a sua gama de dimensões de articulação e operação com os Estados e o sistema econômico mundial que abrangem desde o local até o mundial, fazem que o narcotráfico seja um assunto essencialmente geopolítico ao precisar inerentemente de territórios que serão utilizados de formas particulares, assim como a participação de agentes/atores no estabelecimento de relações de poder com outros atores/agentes.

Logo, se utilizará o princípio metodológico do campo da geopolítica para diferenciar e organizar em categorias de ação e estabelecimento de relações de poder às diferentes forças que intervêm na irrupção do narcotráfico na vida política e civil da nação mexicana. Para o anterior se aproveitarão as caraterísticas fundamentais do campo da geopolítica que dotam ao conhecimento produzido de: a) dinamismo, ao ser uma área que se centra nas ações dos atores/agentes em questões político/espaciais e não nos lugares comuns da geografia descritiva e estática; b) ideologização do campo e o pragmatismo do conhecimento produzido através do seu uso; c) centralidade no pensamento estratégico-militar; d) aplicação e intervenção interdisciplinar ao ser uma técnica que permite a articulação de diversos estudos particulares sobre um território que não apenas leva à consideração as relações de poder e os agentes/atores envolvidos, senão que considera desde fatores mais próprios da geografia clássica como a 
conformação física do território em questão até a bagagem histórico-cultural da população, assim como a mobilidade inter-escalar que permite obter perspectivas alternativas e que quebram com o paradigma analítico do Estado-nação (VISENTINI: 2009).

O capítulo utilizará, portanto, a técnica da identificação de escalas de análise do espaço territorial nas suas acepções físicas e de ação social fazendo ênfase no narcotráfico como fenômeno global, em um primeiro momento, continental e nacional (México e Colômbia) observando sempre a oscilação do mesmo fenômeno em distintas escalas, já que se pressupõe que as representações e a percepção do fenômeno mudam quando alternamos entre uma escala e outra (Gama, 1998). A estrutura escalar utilizada será definida a partir da estruturação geopolítica do espaço social e das relações de poder correspondentes na: 1) escala local: 2) escala regional; 3) escala nacional; e 4) escala mundial; o anterior sendo relacionado a cada escala de produção de poder no espaço-tempo social, sendo estas: a) espaço doméstico, b) espaço de produção; c) espaço de cidadania; e d) espaço mundial.

Cada uma das quatro escalas possuirá, por sua vez, quatro eixos que definirão o estabelecimento de relações de poder entre os atores/agentes agindo sobre o território: i) mecanismo estrutural do poder; ii) forma de direito; iii) formas de racionalidade; iv) instituições privilegiadas; e v) unidades de prática social.

Esta técnica permite uma aproximação estruturada a partir das escalas geográficas levando à consideração aos distintos atores/agentes que participam em relações de poder dentro do território no marco do combate às drogas; para a presente dissertação, os grupos civis adquirem uma posição central dentro da estruturação de relações de poder entre o Estado, o narcotráfico e eles mesmos através do cristal da criação e construção do Outro e das alteridades indesejáveis desenvolvido no capítulo prévio; portanto, a população civil é reivindicada como um ator central do conflito. O método apresentado oferece a possibilidade de analisar o fenômeno do narcotráfico como relações de poder e o exercício das mesmas em territórios trans-escalares desde a sua base no espaço local, a sua organização no espaço nacional e as implicações transnacionais que advêm em questões econômicas e de criação de políticas de segurança e intervenção emanadas da hegemonia como o Plan Colombia e a Iniciativa Mérida, as suas ramificações e o impacto que terão na população civil em escalas regionais e locais. 


\section{Consequências para a população civil}

Esta seção da dissertação se caracteriza por ser o ponto de união entre os dois pilares anteriores: a teoria do Outro e a teoria geopolítica do combate ao narcotráfico. Para levar a cabo este labor é necessário fazer uma investigação e um recorrido hemerográfico dos eventos mais emblemáticos de ataques à população civil no contexto da guerra contra as drogas no México, iniciada em 2006 e ainda em desenvolvimento. O critério de seleção dos três eventos emblemáticos (Tlatlaya, San Fernando e Ayotzinapa) se deve, em parte, à difusão mediática que tiveram, a existência e disponibilidade do material necessário e por representarem a essência da militarização do conflito ao serem os carrascos, em cada caso: 1) agentes do Estado (Exército mexicano); 2) agentes do narcotráfico (Los Zetas); e 3) agentes do NarcoEstado (Guerreros Unidos e policiais municipais).

Nos primeiros dois casos (Tlatlaya e San Fernando) se seguem as linhas de: a) ataque contra categorias populacionais definidas no marco da teoria sobre o Outro; e b) a essência geopolítica do narcotráfico e o uso das políticas de combate ao narcotráfico como recurso de ação das forças estatais e do narcotráfico. No terceiro caso (Ayotzinapa) se utilizam em conjunto ambas as linhas mencionadas e se aprofunda no agir do aparelho de justiça do Estado mexicano mediante uma análise detalhada da progressão do caso Ayotzinapa desde os acontecimentos, as primeiras investigações, o veredito "oficial" e o veredito "não Estatal" com o uso de documentos oficiais da Procuraduría General de la República - PGR e os informes dos grupos independentes GIEI e EAAF.

A análise da resposta cidadã diante dos eventos analisados foi realizado da mesma maneira através da investigação hemerográfica e acompanhamento do desenvolver de eventos paralelos; em conjunto com a própria experiência do autor ao haver se encontrado presente e haver sido participe dos eventos de resistência cidadã no marco do caso Ayotzinapa, o qual foi salvo e relatado no blog ${ }^{4}$ do qual o autor é co-escritor.

Um problema metodológico considerável para a redação de esta seção em particular foi o fato da continuidade do conflito no México e a constante aparição de informações novas, a existência de informação não confiável e o acontecimento de sucessos relevantes para a dissertação no momento da redação da mesma. A delimitação estrita de análise a esses três casos foi necessária, mas não se deixaram de fora os acontecimentos paralelos à redação da dissertação, embora sejam utilizados apenas como exemplos ou referências. Finalmente, os

\footnotetext{
${ }^{4}$ La Serpiente Desplumada - https://laserpeintedesplumada.wordpress.com/inicio/
} 
acontecimentos ou aparição de novas informações relevante para o tema e que tiveram lugar após o dia 1 de julho de 2016 não aparecerão na presente dissertação.

\section{RESUMO CAPITULAR}

A presente dissertação é dividida em quatro capítulos centrais e um quinto destinado às considerações finais. O primeiro capítulo - O Estado mexicano e a questão do outro - estabelece o ponto de partida para contextualizar e compreender paralelamente dois pontos centrais do argumento: 1) a conformação político-histórica do Estado mexicano contemporâneo; e 2) a conformação da percepção do Outro desde o primeiro contato com os europeus. Em primeiro lugar se estabelece a gênese e ordem fundacional da concepção do Outro no binômio primordial do índio-conquistador e a fragmentação, evolução e mutação de este binômio no decorrer da história mexicana passando por quatro momentos principais: a) conquista, b) independência, c) revolução; e d) pós-revolução e contemporaneidade. Cada etapa é acompanhada de uma análise da composição e organização política da nação, do pensamento ou ideologias do momento e as mudanças paradigmáticas que aconteceram.

O segundo capítulo - A guerra contra as drogas - trata sobre a questão das drogas, seu uso e seu consumo. Em primeiro lugar se faz uma análise do consumo histórico de drogas e a posterior proibição imposta desde a hegemonia, fazendo ênfase na sua proibição por motivos que vão além das substancias per se e que correspondem mais à dimensão do social. Posteriormente se desenvolve a estruturação geopolítica por escalas de nível de ação nos territórios do narcotráfico, isto é: desde o nível local até o mundial expondo a configuração das relações de poder que o narcotráfico estabelece entre os atores/agentes tanto do estado, civis e do próprio narcotráfico para com os territórios de ação. Finalmente, se exploram as políticas de ação contra as drogas emanadas da hegemonia como o Plan Colombia, mas fazendo especial ênfase na Iniciativa Mérida para aprofundar além dos objetivos oficiais de estas políticas de ação para demonstrar as implicações extraoficiais e de caráter político para com as sociedades civis e as alteridades dissidentes em questão para cada país. 
De esta forma, o terceiro capítulo - A população civil e o extermínio legitimado da dissidência - estabelece a existência de um NarcoEstado a partir da lógica de funcionamento geopolítico do narcotráfico exposta no segundo capítulo. Em primeiro lugar se faz uma análise e um recorrido histórico do atual governo do PRI no México (2012-2018) e a sua reorganização levando à consideração à atual configuração territorial e política do narcotráfico com base na história política da nação e do PRI expostas no primeiro capítulo. Utilizando a teoria do Estado de exceção de facto de Giorgio AGAMBEN (2005), se teoriza sobre a implementação proposital de um Estado de suspensão de garantias em prol da segurança que justificaria o combate a qualquer ameaça percebida por parte do Estado mexicano, isto em dois momentos distintos: o governo de Calderón e a continuação do governo de Enrique Peña Nieto, estabelecendo as diferenças para cada caso e considerando a variável que o narcotráfico representa. Para o anterior, se utilizam dois eventos de ataque à população civil: 1) o caso Tlatlaya; e 2) O massacre de San Fernando. Estes dois eventos, perpetrados em um caso por agentes do Estado e no outro por agentes do narcotráfico configuram dois tipos de ataque à população civil portadora de estigmas sociais que os fazem parte do Outro indesejável.

O capítulo quatro - Ayotzinapa - continua com a linha do capítulo anterior com a particularidade de que este se centra totalmente no caso mais emblemático de ataque à população civil: o sumiço dos 43 estudantes normalistas de Ayotzinapa. Este capítulo apresenta um ataque perpetrado em ação conjunta por agentes do Estado e do narcotráfico, reforçando assim a afirmação da existência de um NarcoEstado e os ataques dirigidos contra grupos portadores de caraterísticas e estigmas indesejáveis. Com sustento em documentos oficiais do governo e de organismos internacionais de investigação e de defesa aos direitos humanos, se apresentam os eventos relatados sobre o sumiço, as investigações oficiais e a chamada "verdade histórica" que o governo mexicano apresentou e a versão contrária de agências independentes de investigação que derrubam a suposta "verdade histórica". Finalmente, o capítulo discute a questão da resposta da população civil diante do caso Ayotzinapa e a repressão estatal sofrida em conjunto com a organização e toma das armas de setores civis para combater e se defender tanto dos narcotraficantes como das forças estatais.

Para finalizar a presente dissertação, o capítulo - Considerações finais - está dividido em duas partes. A primeira gira em torno à discussão do fracasso total e absoluto da guerra contra as drogas pela própria essência ineficaz, ilegítima e contraditória ao ter sido concebida como uma ferramenta de controle, antes de tudo, social no combate à dissidência e à arbitrariedade do desejável e indesejável. Posteriormente se apresentam alternativas ao combate armado para 
atacar e desarticular aos cartéis da droga sem necessariamente criminalizar o consumo e abrir a porta para o ataque as alteridades dissidentes ou indesejáveis a partir da criminalização que o consumo de drogas oficialmente traz consigo.

A segunda parte do capítulo - Considerações finais - discute o futuro em questão para a nação mexicana. Se apresenta o estado atual da União sob o retorno do PRI e a convulsão social presente em distintos frentes e eventos para estabelecer um ponto de partida para pensar e começar a discussão sobre o futuro do país a partir das experiências do passado, expostas no primeiro capítulo, e da irrupção da guerra contra as drogas na vida da nação durante a última década. A partir do anterior se apresentam os passos considerados como necessários para começar a mudança e a discussão de um novo projeto de nação. Finalmente, se discute a dificuldade inerente de reconhecer o momento crítico do país, e do mundo, para preparar os espíritos e as vontades diante da tormenta que se aproxima. 


\title{
O Estado mexicano e a questão do Outro
}

\author{
"Oscilamos entre la entrega y la reserva, entre el \\ grito y el silencio, entre la fiesta y el velorio, sin \\ entregarnos jamás. Nuestra impasibilidad recubre la vida \\ con la máscara y sube al cielo hasta distenderse, romperse \\ y caer como derrota y silencio. Por ambos caminos el \\ mexicano se cierra al mundo: a la vida y a la muerte."
}

(Octavio Paz, El Laberinto de la Soledad, 1950)

\section{A concepção das alteridades}

A questão do Outro e a sua concepção pelo olhar hegemônico representa um eixo fundamental nas dinâmicas sociais intranacionais e internacionais. Os seus significados, embora sejam diferentes de origem em distintas zonas geográficas, atingem e permeiam às sociedades em todos seus estratos, tendo consequências diretas na forma de articulação dos indivíduos e das comunidades entre si. A alteridade, diante do olhar do observador, traz consigo mal-estar, não é prazeroso e, ao invés, parece vir sempre acompanhada de terror, são "una pareja inseparable en nuestra cultura”. (BARTRA: 2013, p. 9).

Porém, como tentar entender o surgimento da concepção do Outro? E, como explicar as conotações negativas que a alteridade parece ter sempre diante do nosso olhar? Seria necessário, tal vez, abandonar a nossa posição e tentar nós olharmos desde a posição daquele que nós consideramos como um Outro, um diferente, algo que não é nós. Ao fazer esse exercício, mesmo com as evidentes dificuldades de assumir simuladamente uma posição que não é a nossa 
e sem a experiência de vida que o anterior implica, provavelmente as conotações negativas continuarão presentes. Parece ser que os mecanismos básicos de autodeterminação fundados na lógica de -nos definirmos a partir daquilo que não somos- precisam do terror e do medo para afastar-nos do nosso contrário-definidor e tentar submetê-lo para sobreviver.

Como fazer então para entender esse processo em um nível macro tendo como exemplo às sociedades em distintos momentos históricos? O anterior sob a premissa de que o mecanismo de autoafirmação de um grupo populacional ou de um indivíduo se fundamenta na diferenciação com aquilo que não se é e, portanto, o olhar diferenciado da alteridade e a angustia e mal-estar, como fatos genéricos, são permanentes e imutáveis. A mutabilidade encontra-se nas particularidades acidentais tanto tangíveis como intangíveis ${ }^{5}$ que dependem do contexto histórico, do nível de homogeneidade ou heterogeneidade de uma sociedade ou grupo, das necessidades econômicas do momento ou da dinâmica demográfica expressada em migrações e os efeitos que o anterior tem nas culturas em nova convivência (BARTRA: 2013).

A compreensão da origem e da evolução do entendimento e olhar do Outro na história mexicana é necessário para entender as implicações que essa visão continua tendo na contemporaneidade. A violência direcionada, as políticas estatais e sociais, a nossa mesma distribuição geográfica dentro do território e a segregação que possa existir inclusive em questões de distribuição do trabalho e da riqueza, não são fatores que existam de um dia para o outro. Se bem não é possível falar da permanência dos mesmos parâmetros que provocam a diferenciação entre o estabelecido hegemonicamente e o considerado como Outro, também não é possível falar de uma descontinuidade histórica de diferenciação da alteridade. Tampouco podemos cair em lugares comuns de conceitos generalizantes da diferenciação de um para o Outro como poderiam ser questões raciais, religiosas ou culturais, senão que temos de partir desde a premissa de que esses conceitos de diferenciação primordial vão se fragmentando e diferenciando conforme o decorrer da história e a diversificação dos acontecimentos sociais, econômicos, ambientais, etc., levando a consideração a mesma inserção da população ou do território em dinâmicas cada vez mais globalizadas sem, ao mesmo tempo, perder de vista as particularidades de cada latitude.

Além do mais, seria ingênuo acreditar que o processo de autoafirmação diante da alteridade acontece de forma pura, imaculada e autônoma. Roger Bartra (2013) aprofunda na falácia da

\footnotetext{
${ }^{5}$ Como as grandes categorias históricas: Raça, cultura, religião, etc., até as fragmentações e misturas posteriores resultado do processo da globalização, por exemplo: posição socioeconómica, origem geográfica, pensamento político, gostos individuais, etc.
} 
autoafirmação imaculada e autônoma no livro "Territórios do Terror e da Alteridade" lembrando da existência de redes imaginarias de poder que "[...] permiten explicar las nuevas formas que alimentan y reproducen la legitimidad de los Estados posmodernos [...]" (BARTRA: 2013, p. 13) lembrando que a autoafirmação de uma população, ou no caso, de um Estado-nação depende da diferenciação da alteridade para se legitimar como defensor do que essa população é. $\mathrm{O}$ anterior precisa da prática constante de "[...] mitos polares de la normalidad y la marginalidad, de la identidad y la otredad, y cristalizan en simulacros estrechamente ligados a los procesos de dislocación crítica [...]” (BARTRA: 2013, p. 13).

Logo, o discurso do Outro ameaçante, da alteridade desconhecida e negadora do que -nós somos- e de territórios de terror ocupados pelo Outro, é produzido desde uma posição de poder político-administrativo e de uma situação civilizatória/social de dominação e superioridade assumida, no caso mexicano, desde a conquista do índio não branco pelo europeu branco. Tratase de uma reprodução ideológico-discursiva que se sustenta em séculos de história e que conta com a capacidade de mutação para articular-se de distintas maneiras em distintas épocas; “[...] não se trata, tão somente, de processos de 'produção social da diferença cultural', mas da produção histórica da subordinação colonial, isto é, um padrão de relação de poder que possui a capacidade de se transformar em uma nova forma de estrutura social de dominação" (SILVA: 2015, p. 16).

Eis a questão do agir individual ou coletivo da sociedade ou dos indivíduos que determinam e reproduzem através das gerações o que é desejável e o que é indesejável levando a consideração fatores socioeconômicos, de classe ou raciais, para determinar quem pode e quem não pode, por exemplo, no marco da guerra contra as drogas, cheirar pó. Ao mesmo tempo surge a questão de ter, por um lado, o agir individual e autônomo dos indivíduos, e por outro lado, a existência de uma estrutura de pensamento, de costumes e de concepção da alteridade estabelecida, construída, desconstruída e reconstruída de novo desde a época pré-hispânica e o primeiro contato com os europeus. A conciliação de uma provável contradição entre a percepção positiva do jovem que cheira na boate e a percepção negativa do favelado que cheira embaixo da ponte no imaginário coletivo, sendo que o combate às drogas é uma noção hegemônica, tem paralelismos evidentes com a noção de Pierre Bourdieu (2002) sobre a distinção do que é aceitável e inaceitável, daqueles que impõem essa visão e daqueles que a aceitam, a internalizam e a reproduzem.

Nesse sentido, Bourdieu (2002) tenta fazer uma conciliação entre: a) o determinismo que a estrutura social preexistente tem sobre o indivíduo; e b) a suposta liberdade dos sujeitos para 
autodeterminar a sua noção de desejável e indesejável independente da estrutura social na que foram criados. No caso, o autor estabelece um ponto médio enquadrado no conceito de habitus entendido como a interiorização da estrutura social pré-existente na qual o indivíduo teria nascido e crescido e que servirá como matriz de estruturação das percepções futuras que o sujeito terá de maneira pessoal. Portanto, é a partir do habitus, como a assimilação das estruturas do grupo social no qual se desenvolve o sujeito, que se produzirão os seus pensamentos, ideias, concepções e a distinção entre o que é desejável e indesejável, isto quer dizer que o indivíduo não é totalmente livre, mas tampouco está totalmente determinado (CRIADO: 2009). Esta assimilação da estrutura social pré-existente acontece principalmente na socialização primaria no âmbito familiar, comumente, e continua nos primeiros anos da educação escolar a qual, no México, é projetada pelo Estado através da Secretaria de Educación Pública - SEP, instituição insígnia da revolução e do regime priísta. Portanto, o habitus dos indivíduos não pode ser explicado apenas a partir da sua situação presente senão que necessariamente precisa de ser remitido à dimensão histórica do grupo social em que se desenvolveu (CRIADO: 2009), dimensão que abarca escalas desde o local até o global, sendo a influência da história inversamente proporcional à abrangência da escala espaço-social.

No entanto, é necessário posicionar o conceito de habitus em escalas de análise maiores do que o agir individual para entender a criação de alteridades indesejáveis por desígnio estatal. Nesse sentido, segundo Criado (2009) analisando o teorizado por Bourdieu, é possível falar de um "habitus de classe" pela própria origem social das estruturas interiorizadas e, portanto, torna-se possível falar na dimensão de um habitus inter-escalar que pode se localizar tanto em comunidades locais, urbanas, nacionais e internacionais. Quando os esquemas de criação de práticas comuns para os indivíduos de uma sociedade se elevam da escala local ou de classe para o nível nacional, tornam-se práticas ideológicas repetidas ritualisticamente seja de maneira oficial e festiva através da ocupação dos espaços públicos de ação e comunicação (como as tradições e dias feriados oficiais) ou através da sua perpetuação vedada como parte do cenário físico, da linguagem e de práticas que se auto sustentam através da sua própria prática como uma espécie fita de Möbius. Isto é a internalização e naturalização de uma estética visual do espaço público e privado composta pelos corpos que o ocupam e as práticas que consideramos adequadas nesse espaço pelo próprio fato de serem praticadas e que se conformam na normalidade natural e essencial do nosso cenário de atuação. Esta -ordem natural social- não é imutável e tampouco pode se falar da evolução de uma única ordem natural social, senão que ao decorrer da história, novos elementos, ideias e revoluções paradigmáticas se unem para, a 
partir do pré-existente, conformar uma ordem na qual prevalecerão elementos prévios em convivência com o novo.

Portanto, na sociedade mexicana contemporânea, por exemplo, seria possível apreciar formas, práticas e concepção da estética física do espaço ideal remanescentes do passado colonial ou até mesmo pré-hispânico. A arquitetura e a distribuição espacial das cidades como da residência privada, assim como a relativa homogeneidade de formas de interação do uso da língua, são janelas que permitem observar as pequenas particularidades de estruturação social do desejável e indesejável a partir do contraste com uma outra sociedade nacional e as suas próprias formas e práticas.

De esta forma é possível falar da existência nacional de um "habitus mexicano" que vem se transformando desde o primeiro contato entre europeus e americanos no território e a permanência da essência das primeiras formas, práticas e composição ideal da estética do espaço físico que se originaram a partir do encontro de dois mundos. Considerando a teoria de Bourdieu (2002) e as particularidades do processo de conquista espanhola do território americano, temos uma construção sistemática da "ordem natural social" da Nova Espanha a partir do "habitus de classe" binário e primordial: espanhol conquistador - índio conquistado. A construção de esta ordem está estritamente vinculada com a posição hegemônica daquele que monopoliza a violência e exerce o domínio sobre os médios militares, humanos e de produção. Não pode se falar de uma construção de alteridades por desígnio estatal em este momento histórico primordial, senão de uma construção por via de condições sociais e materiais de existência circunstanciais (mas não inocentes) da conquista (CRIADO: 2009). Porém, a prevalência da essência de esse primeiro momento nas práticas, formas e idealização da estética do espaço na sociedade mexicana futura através da repetição ritualística e festiva de umas no marco do nacionalismo, assim como a repetição cotidiana e vedada de outras no dia a dia, faz que este habitus e o uso das categorias do desejável e indesejável seja assunto de Estado.

Para melhor entender o anteriormente exposto e a sua inserção na dinâmica do Estado mexicano contemporâneo, é necessário voltar às origens da concepção da alteridade no México préhispânico, colônia, revolução e Estado pós-revolucionário. 


\section{Origens do Estado mexicano}

\section{Civilizações originárias, primeiros contatos e conquista}

O território que atualmente faz parte dos Estados Unidos Mexicanos possui uma rica história de ocupação constante por distintos grupos e civilizações durante milhares de anos. A parcela do continente americano denominada como Mesoamérica ${ }^{6}$ foi testemunha do apogeu de uma série de civilizações ${ }^{7}$ que constituiriam parte importante da cultura pré-hispânica do México e que Guillermo Bonfil Batalla (1990, p. 21) como o "México profundo"8.

No momento da chegada dos espanhóis encabeçados por Hernán Cortés, a civilização dominante da região era o Império Mexica desde a sua capital Tenochtitlan, atual Cidade do México, maior do que as grandes metrópoles europeias do momento tais como Paris e Londres. A organização, a limpeza, os jardins e a ornamentação dos prédios impressionou aos espanhóis e a grandeza de Tenochtitlan demonstrava que os ibéricos não estavam encontrando um continente deserto, senão um lócus de prosperidade (MANN: 2002). Os mexicas dominavam a região do Vale do México e o centro-sul do atual território mexicano, originados como um povo nômade do Norte em busca de um local designado pelos deuses para se estabelecer e construir a sua capital, conseguiram criar uma aliança com outras duas cidades-Estados do vale (Texcoco e Tlacopan) para derrotar a cidade-Estado de Azcapotzalco e estabelecer o domínio do Império na região.

A região mesoamericana era um caldeirão no qual conviviam distintos grupos populacionais em direta interação. O domínio dos mexicas na região, por exemplo, estava baseado no poderio militar do império que se expandia mediante conquistas e a tributação dos povos submetidos. Ao falar do anterior estamos necessariamente nos aproximando de relações interculturais ou até

\footnotetext{
${ }^{6}$ Mesoamérica: Região cultural do continente que se estende desde o centro do México até a Guatemala, Honduras, Belize, Nicarágua, El Salvador e Costa Rica.

${ }^{7}$ Os dois exemplos emblemáticos de civilizações que floresceram na zona centro-sul do atual México e parte da América Central são o Império Mexica (Astecas) e a Civilização Maia, lembrando que conviviam e interagiam com outros grupos populacionais; porém, há civilizações que pré-datam aos mexicas e maias e que estabeleceram os fundamentos culturais da Mesoamérica: Olmecas, totonacas, zapotecas, mixtecas, teotihuacanos, toltecas, huastecas, purepechas e chichimecas.

${ }^{8}$ A noção de "México profundo" de BATALLA se refere à diversidade de povos, comunidades e setores sociais urbanos que compõem a maioria da população no território mexicano; os distingue do resto da sociedade mexicana por serem grupos que entendem e organizam a sua vida a partir de formas de raiz mesoamericana e não europeia; para o autor, esta parcela da população foi negada e esmagada pelo México imaginário: o projeto de nação emanado da raiz civilizatória europeia.
} 
internacionais, se for possível usar o termo. A interação entre povos distintos em relação assimétrica, em questões econômicas ou militares traz consigo a questão da concepção do Outro. No contexto histórico da Mesoamérica, especificamente do apogeu do Império Mexica, temos uma relação assimétrica de dominação de um império sobre outros grupos populacionais.

\footnotetext{
“Mesoamérica, esto es, el núcleo de lo que sería más tarde Nueva España, era un territorio que comprendía el centro y el sur del México actual y una parte de Centroamérica. Al norte, en los desiertos y planicies incultas, vagaban los nómadas, los chichimecas, como de manera genérica y sin distinción de nación llamaban a los bárbaros los habitantes de la Mesa Central. Las fronteras entre unos y otros eran inestables, como las de Roma.” (PAZ: 1999, p. 98).
}

Porém, como se justificava ou se criava a necessidade de impor o domínio desde a perspectiva dos mexicas? Qual era a percepção do Outro por parte do império e os seus habitantes ao conquistar um povo? Podemos tomar esse exemplo como um primeiro momento de auto definição a partir da diferenciação da alteridade no México e em direta comparação com o primeiro encontro entre indígenas e europeus; o encontro de dois mundos distantes e desconhecidos entre si que aconteceu nas Antilhas com a chegada de Colombo e os primeiros europeus e posteriormente com a chegada dos primeiros colonizadores, trouxe consigo uma questão pivô para a história latino-americana e europeia: o encontro frente a frente do desconhecido, do Outro europeu e o Outro americano.

Retomando a ideia de Roger Bartra (2013) sobre o terror e o medo que o Outro traz consigo diante de nós, seria possível e legítimo perguntar se a aversão que a ideia de um Outro desconhecido ocasiona seria um sentimento universal compartilhado por toda a espécie e as distintas civilizações? Ou perguntar se a aversão e o terror obrigatoriamente têm de ser respondidos proporcionalmente com sentimentos de superioridade e a necessidade de submeter ao Outro? Concedendo que o desconhecido, de fato, provoca um certo grau de angustia na psique humana, será que a reação violenta e compensadora de assumir-se superior ao Outro é produto de um contexto particular europeu do momento e que existem outras maneiras de aproximar-se do desconhecido?

Pois bem, Tzvetan Todorov (2003) tenta responder à questão anterior afirmando que de fato o posicionamento diante do Outro, embora provoque angustia e mal-estar essencial, pode se desenvolver sem necessariamente se assumir superior pela própria natureza ou por desígnio divino e, ao mesmo tempo, estabelecer relações de dominação e sustentar um aparelho econômico de magnitudes imperiais. Todorov o exemplifica com a prática do discurso da 
diferença nos índios e nos espanhóis. Para o espanhol "[...] o postulado da diferença leva facilmente ao sentimento de superioridade, e o postulado da igualdade ao de diferença" (TODOROV: 2003, p. 87). O anterior resulta curioso se pensarmos que durante os primeiros contatos entre europeus e índios, Todorov lembra que, eram os segundos aqueles que aprendiam a língua dos europeus enquanto eles precisavam de interpretes; Todorov escreve com contundência: "Diremos, desde já, que não há, evidentemente, nenhuma inferioridade 'natural' dos índios no plano linguístico ou simbólico”(TODOROV: 2003, p.87).

As formas de organização indígenas na época pré-hispânica podem ser comparadas, como Octavio Paz o faz (1999) com o mundo helenístico e a existência de múltiplas cidades independentes. Para Paz, a existência de "un gran número de ciudades independientes (...) no impiden, sino subrayan, la uniformidad cultural de este universo” (PAZ: 1999, p. 99-100). Portanto, a diferenciação entre as civilizações indígenas não acontecia por questões raciais nem culturais ou pela diversidade e originalidade de cada uma. A diferenciação do Outro continua provocando mal-estar, porém, não impediu o sincretismo cultural das civilizações. Poder-se-ia falar da hegemonia de formas como finalmente foi a perpetuação das formas teotihuacanas no território mesoamericano ${ }^{9}$ as quais finalmente seriam assimiladas e reforçadas pelo Império Mexica, o "heredero de las civilizaciones de la Meseta” (PAZ: 1999, p. 101).

Embora se fale de formas hegemônicas no território mesoamericano, estamos ao mesmo tempo falando de uma série de civilizações independentes que as praticavam, isto é, essas formas foram adotadas de maneira voluntária ou por inércia natural mais do que uma imposição violenta fundada na superioridade assumida de um em cima do Outro. Tampouco é possível negar o domino do Império Mexica por meio da força militar e a tributação, porém, se tratava de uma dominação econômica que não impunha formas culturais nem religiosas, e caso as diferenças existirem, seriam irrelevantes. Porém, a presença do "Outro mexica" no universo das populações submetidas também gera mal-estar produto da imposição de tributos e pelo próprio fato de estar na condição de dominado, situação que posteriormente facilitaria a conquista espanhola de Tenochtitlan e a queda do Império Mexica.

De maneira diferente do que acontecia entre as populações originárias, o primeiro contato entre indígenas e europeus foi ao mesmo tempo o encontro de cosmovisões distintas, religiões e

\footnotetext{
${ }^{9}$ Como Paz o exemplifica ao argumentar a falta de influência de Chichen Itzá (maia) na cidade de Teotihuacan (planalto central) em contraposição à influência de Teotihuacan em Chichen Itzá (p. 100) assim como a prevalência de rituais do planalto central no restante do território que seriam "[...] comuns a todas as culturas: agricultura do milho, calendário ritual, jogo de bola, sacrifícios humanos, mitos solares e da vegetação, etc.” (PAZ: 1999, p. 100).
} 
formas de organização opostas, rasgos físicos e linguagens corporais diferentes. Porém, os momentos históricos, o pensamento coletivo e a cosmovisão religiosa dos grupos que se encontraram nesse momento marcou uma diferença fundamental: os europeus assumiram um olhar desde a hegemonia outorgada pela religião cristã e a sua natureza confrontadora, violenta e depredadora; características essenciais das religiões abraâmicas.

Esse primeiro encontro, exposto por Tzvetan Todorov (2003), permite apreciar o olhar hegemônico do espanhol para o indígena ao considera-lo parte da paisagem, não diferenciado da natureza, nus, carentes de religião e de cultura. O olhar de Colombo e dos primeiros navegantes europeus que chegaram nas Antilhas sentou as bases para o pensamento generalizado no restante do continente. Octavio Paz também faz referência ao olhar hegemônico do europeu diante da "pluralidad de ciudades y culturas" que é eclipsada pela “relativa homogeneidad de sus rasgos más característicos ${ }^{10 "}$ (PAZ: 1999, p. 99). No caso mesoamericano, essa relativa homogeneidade das culturas que contrasta com a diversidade de populações se deveria à substituição de formas particulares por formas religiosas uniformes (PAZ: 1999) o qual é muito perceptível ao ver, por exemplo, o culto compartilhado de Quetzalcoatl por parte de distintas civilizações como os Maias que o chamavam de Kukulkan.

A relação automática que o espanhol faz entre diferença e superioridade fica evidenciada nos relatos de Bartolomé De Las Casas ao descrever às populações indígenas encontradas pelos europeus. Trata-se de uma relação de dominado e dominador, desde uma perspectiva cristã e fundada em uma suposta ordem natural: os índios, ao serem parte da paisagem e da natureza, estavam legitimamente sujeitos à exploração do homem branco e cristão, possuidor da cultura e da única religião verdadeira:

\footnotetext{
"Todas estas universas y infinitas gentes a todo género crio Dios los más simples, sin maldades ni dobleces, obedientísimas y fidelísimas a sus señores naturales y a los cristianos a quien sirven; más humildes, más pacientes, más pacíficas y quietas [...] Son también gentes paupérrimas y que menos poseen ni quieren poseer de bienes temporales; y por esto no soberbias, no ambiciosas, no codiciosas[...] entraron los españoles, desde luego que las conocieron, como lobos y tigres y leones cruelísimos de muchos días hambrientos. Y otra cosa no han hecho de cuarenta años a esta parte, hasta hoy, y hoy en este día lo hacen, sino despedazarlas, matarlas, angustiarlas, afligirlas, atormentarlas y destruirlas por las extrañas y nuevas y varias y nunca otras tales vistas ni leídas
}

${ }^{10}$ Os rasgos característicos mencionados podem ser considerados até os aspectos raciais que, se bem, existem diferenças físicas entre as populações indígenas da Mesoamérica, diante do olhar europeu, eram todos não-brancos 
ni oídas maneras de crueldad, de las cuales algunas pocas abajo se dirán, en tanto grado, que habiendo en la isla Española sobre tres cuentos [millones] de animas que vimos, no hay hoy de los naturales de ella doscientas personas." (DE LAS CASAS: 2005, pp: 1-2).

É necessário ressaltar que, embora o primeiro encontro dos europeus com os indígenas das Antilhas tenha sentado as bases de pensamento do Outro indígena, o encontro dos espanhóis de Cortés com os mexicas e o seu imperador Moctezuma foi um tanto diferente. O imperador mexica recebeu aos espanhóis com as portas da cidade abertas. Octavio Paz se pergunta: “¿Por qué cede Moctezuma? " (1999, p. 102) e se questiona a fascinação que o imperador e a população sentia pelos espanhóis. A questão do Outro e a sua presença que gera mal-estar fica em dúvida, mas a resposta radica em que, pelo menos em um primeiro momento, os europeus faziam parte da cosmovisão mexica do tempo cíclico, do fim de uma era e do começo de outra, de ollin e Tonatiuh ${ }^{11}$. Os europeus não eram originalmente um Outro, senão o sinal do fim de uma era e o começo de outra dentro da própria cosmovisão mexica (PAZ, 1999). O espanhol como Outro ameaçante seria produzido posteriormente e seria, agora sim, o começo da guerra de conquista.

Após a invasão espanhola e a conquista do Império Mexica, o território passa a ser administrado pela coroa espanhola a qual o reorganizou no que seria conhecido como o Vice-reino da Nova Espanha com uma extensão que abarcava desde a América Central até chegar ao sul do atual Canadá, junto com a ilhas de Cuba e das Filipinas e tendo como capital à Cidade do México, seria a mais prezada joia do Império Espanhol. O peso específico da Nova Espanha dentro do aparelho econômico imperial foi o mais importante de todos os vice-reinos. O anterior traz consigo uma série de implicações raciais e sociais de alta complexidade e importância histórica se consideramos a diversidade de população originária que existia nesse território antes da chegada dos europeus.

A doutrina católica, em conjunção com a situação histórica da Espanha no momento da conquista do México ${ }^{12}$, foram as ferramentas com as quais se sentaram as bases de diferenciação do europeu e do indígena, lembrando que a mesma categoria de índio foi criada pelos próprios

\footnotetext{
${ }^{11}$ Ollin: Significa movimento em língua náhuatl e junto com Tonatiuh (o deus do quinto sol, havendo quatro soles antes dele) faz referência ao mito do Sol cíclico que permanece em movimento através do céu - El mito del quinto sol - Armando BLANCO e Malú VERA em Tlamatini, publicado em 7 de abril de 1989, disponível em: http://tlamatinisextosol.tripod.com/id2.html - acessado em março de 2016.

12 Os espanhóis eram guiados por uma espécie de desígnio divino derivado do momento histórico espanhol e a sua vitória sobre os ouros na Reconquista da península ibérica (SILVA: 2009). A vitória da cristandade sobre os mouros marcou a etapa de descoberta e conquista da América como uma guerra justa para expandir a religião vitoriosa do reino e da Europa.
} 
espanhóis em clara homogeneização arbitraria da diversidade pré-hispânica. Através de preceitos cristãos como a caridade ou a subsidiariedade, o europeu se auto assumiu superior aos indígenas e tomou para si mesmo a missão de salvar as almas dos nativos. As "boas intenções" da cristandade foram o caminho para o inferno dos índios durante o brutal processo da conquista. Características inofensivas e amáveis que os espanhóis perceberam como a simplicidade, a obediência, a fidelidade, a paciência, etc., os fizeram sujeitos de conversão à fé católica para civiliza-los. É perceptível a soberbia e superioridade natural com a que o catolicismo e o europeu se assumem perante a alteridade como um tigre perante uma ovelha (DE LAS CASAS: 2005).

Como foi mencionado anteriormente, a autoafirmação mediante a oposição à alteridade não é pura nem autônoma. O poder hegemônico da Igreja Católica em contubérnio com a Coroa Espanhola precisaram de criar uma dimensão imaginária, embora sustentada em evidências tangíveis ou observáveis, para estabelecer um aparelho de administração social e econômica em clara situação de assimetria diante dos índios. Essa dimensão é descrita por Bartra como um cenário omnipresente de confronto entre uma civilização, no caso o ocidente, contra um "[...] amplio império maligno de otredades amenazantes, primitivas y fanáticas” (BARTRA: 2013, p. 15).

A criação do conceito de índio é um evento visitado por Guillermo Bonfil Batalla (1990, p. 45) quem o como uma denominação arbitraria e genérica de uma civilização morta por decreto ${ }^{13} \mathrm{e}$ que, por sua vez, responde à redução da complexidade social, política e demográfica de uma diversidade de nações, culturas e línguas a uma estrutura de dominação binaria simples: índio conquistado - europeu conquistador (BARTRA, 2013). Seguindo a lógica de Bartra que tem sido utilizada até este momento, a homogeneização arbitraria a partir da autoafirmação vassala diante da alteridade estabelece um segundo momento de concepção das alteridades na história mexicana, o primeiro momento sendo durante a época pré-hispânica entre as civilizações originárias.

\footnotetext{
13 “Sin embargo, en general, los mexicanos sabemos poco de los indios, de 'nuestros' indios. ¿Cuántos son?, ¿Cuántos pueblos componen este abigarrado mosaico étnico que el colonizador encubrió bajo el término único de 'indio': el colonizado, el vencido?, ¿Cuántas lenguas aborígenes se hablan?” (BONFIL BATALLA 1990, p. 45).
} 


\section{Da colônia à independência}

O processo da conquista, além do genocídio das populações indígenas do México, trouxe consigo a criação da categoria socioeconômica de índio que, como já foi mencionado, se fundamentou na homogeneização da diversidade nativa e a sua submissão ao domínio europeu principalmente mediante o regime da Encomienda, necessário para manter a mão de obra que trabalharia as fazendas e na mineração, os índios eram "bens que não convenia malgastar" (PAZ: 1999, p. 111).

A autoafirmação dos espanhóis e a diferenciação da alteridade que aconteceu nesse segundo momento da história mexicana é considerado vassalo por ter sido criado a partir e para benefício dos interesses hegemônicos da Igreja Católica e do nascente Império Espanhol. A evidência mais observável do anterior é o estabelecimento do regime da Encomienda, o qual submetia aos índios ao trabalho forçado sob o pretexto de alcançar a salvação da sua alma. Este regime se configurou como uma permissão temporária para o uso das terras e do trabalho forçado do índio sob os próprios termos da Coroa para evitar entregar o poder absoluto da posse da terra aos conquistadores e dessa maneira evitar o surgimento de uma classe social de senhores proprietários das terras.

Porém, a Encomienda, mesmo disfarçada como a oportunidade para os Outros indígenas se integrarem ao aparelho econômico da colônia, não era mais que um regime de escravidão eufemístico e uma catequese falaz. Octavio Paz faz referência ao anterior ao afirmar que é difícil entender à Encomienda desde uma perspectiva de caráter humanitário e que essa hipótese "hará sonreír a cualquiera que conozca la conducta de los encomenderos con los indígenas" (PAZ: 1999, p. 111). A concepção de uma alteridade, como o caso indígena, de novo se prova a si mesma como carente de inocência. A diferenciação do Outro indígena não é natural, não é autônoma, senão que provocada e direcionada, justificando o extermínio e a submissão ao trabalho escravo sob pretexto de garantir uma suposta "salvação da alma" e a integração ao universo católico para desse jeito virar humano (assimetricamente articulado com a sociedade dentro de um regime de exploração, mas humano finalmente). É uma versão colonial do arbeit macht frei ${ }^{14}$ na sua acepção nazista.

\footnotetext{
${ }^{14}$ Arbeit macht frei: Frase em alemão que significa - o trabalho te liberta - usado amplamente pelo regime nazista que a colocava na entrada dos campos de concentração e extermínio sendo a mais infame e lembrada aquela que se encontra na entrada de Auschwitz. A relação com o regime da Encomienda encontra-se na intenção de fazer ao escravo ou preso acreditar que, de fato, a salvação da sua alma imortal apenas será alcançada através do trabalho forçado como forma de expiação através do fogo, enquanto no nazismo esse trabalho forçado era a forma do
} 
O próprio crescimento da colônia novo hispana favoreceu a diversificação da população da região, diversidade que sempre foi enquadrada forçosamente a partir da perspectiva do binômio conquistado-conquistador independente das diferenças sociais e culturais dos distintos grupos que começaram a conviver na Nova Espanha ${ }^{15}$. Além da multiplicidade inerente negada dentro da categoria índio ${ }^{16}$, começam a aparecer novas populações como os negros trazidos sob o regime da escravidão, os europeus de distintas condições socioeconômicas que começaram se estabelecer na Nova Espanha e a própria miscigenação dos distintos grupos populacionais que a burocracia imperial tentou classificar mediante o que Alan Knight (2010, p. 25) chama de "pigmentocracia colonial".

Com o anterior, resulta evidente o perigo de fragmentação da identidade europeia e o surgimento de conflitos internos que enfraqueceriam o domínio europeu, portanto, para o Império Espanhol seria necessário manter o binarismo essencial do processo da conquista. É um binarismo fundado na raça e a função dentro do aparelho econômico da colônia -índio conquistado e europeu conquistador-, necessário para manter o controle entre um mar de índios (WOLF: 1987).

Uma das hostilidades entre europeus mais ressaltantes é a representada pela categoria dos criollos, os quais pelo fato de terem nascido na colônia não eram sujeitos dos mesmos direitos, privilégios e cargos que os peninsulares ostentavam. Exemplo do anterior é que de entre todos os vice-reis da Nova Espanha, nenhum deles foi um criollo. Porém, é possível apreciar ainda no meio dessa rivalidade a necessidade se manter-se unidos diante das alteridades mais radicais ${ }^{17}$, mentalidade mantida inclusive pelo líder independentista Simón Bolivar ao afirmar que era preferível uma invasão espanhola do que enfrentar uma rebelião negra (ANDERSON: 1993).

A diferenciação da alteridade durante a época colonial foi uma continuação e um terceiro momento do processo rudimentar e sanguinário que aconteceu durante o processo de invasão e

\footnotetext{
indivíduo entregar os seus esforços abnegados ao Estado. No final, é fazer à vítima responsável do seu destino inevitável e exculpar aos carrascos.

15 "[...] sería posible ubicar a los miembros de las castas, según regiones y épocas, en uno u otro de los dos universos fundamentales que integraban la sociedad colonial: los indios o los españoles. Esto no significa ignorar diferencias reales (sociales o culturales) que los separaban de unos y de otros, sino entender su participación en la sociedad novohispana a partir de la dicotomía fundamental del orden social que no podían escapar." (BONFIL BATALLA: 1990, p .125)

16 “El indio es producto de la instauración del régimen colonial. Antes de la invasión no había indios, sino pueblos particularmente identificados. La sociedad colonial, en cambio, descansó en una división tajante que oponía y distinguía dos polos irreductibles: los españoles (colonizadores) y los indios (colonizados)” (Ídem, p. 123).

${ }^{17}$ Ver anexo 1.
} 
conquista do Império Mexica. De ser uma diferenciação radical entre europeus dotados de razão e religião contra elementos de uma paisagem, não humanos e sujeitos naturais de dominação justificada pela religião cristã, passou ser uma diferenciação ainda determinada pelo aspecto racial, porém direcionada à manutenção do aparelho econômico imperial. É a continuação da dominação sobre uma alteridade arbitrariamente homogeneizada e exterminada até ser reduzida em números e submetida assimetricamente aos interesses econômicos e comerciais do império.

A variável que surgiu na colônia foi a emergência e diversificação de novos grupos populacionais diferenciados tanto pela raça como pela posição socioeconômica, a qual já começava a ter influência sobre a diferenciação da alteridade. É possível apreciar uma matização das alteridades que mesmo assim continuam girando em torno do centro europeu ibérico. Quanto mais próximo do centro essa alteridade estiver orbitando, maior acesso terá ao projeto nacional e desfrutará de maiores privilégios e possibilidades de mobilidade social e vice-versa. Porém, o centro se encontra em uma situação de singularidade e em uma ordem piramidal onde a cúspide conta com características perfeitamente definidas das quais ninguém consegue desfrutar na sua totalidade. É um centro inalcançável e excludente o qual apenas uma pessoa por vez pode ocupar e que é reservado para uma linhagem em particular: o trono do Império

O processo de independência do vice-reino da Nova Espanha foi, como os outros movimentos independentistas do continente, influenciado e favorecido por fatores externos. A série de ideias novas e revolucionárias vindas da Europa como a literatura subversiva e revolucionária da França ou Inglaterra alimentaram e estimularam à população colonial que encontrava-se cansada pelas antigas instituições coloniais do Império como a Inquisição e a constante censura (BOERSNER: 1996). É claro que a população geral não tinha acesso a esse conhecimento vindo do outro lado do oceano senão apenas as parcelas europeias da população que tinham acesso à educação e posição econômica alta. Além do mais, as políticas econômicas da metrópole centralizam a administração imperial e transformam a Nova Espanha "en una verdadera colonia, esto es, en un territorio sometido a una explotación sistemática y estrechamente sujeto al poder central" (PAZ: 1999, p. 128).

Como já tinha sido mencionado, existia mal-estar entre a classe criolla que se sentia excluída por parte dos europeus e as ideias revolucionarias às que tinham acesso alimentou o "surgimento de uma consciência social diferente" nessa parcela da população que representava o 16\% da população total (BONFIL BATALLA: 1990). Em conjunto, a ocupação da Espanha 
pelos exércitos napoleônicos gerou um clima de instabilidade e reduziu o poder da metrópole sobre as colônias.

O caso da guerra da independência mexicana se caracteriza por não ter sido um movimento homogêneo e que de fato começou como uma revolta que não buscava a independência, senão a continuidade da adesão à Espanha de Fernando VII, embora quando não existiam mais laços reais com a Espanha além do que Octavio Paz denomina como uma inércia dos 300 anos de domínio espanhol ao afirmar que "[...] los Borbones transformaron a Nueva España, reino vasallo, en simple territorio ultramarino” (PAZ: 1999, p. 128). Foi o sacerdote Miguel Hidalgo que começou a revolta armada para pouco tempo depois ser capturado e fuzilado. O movimento, cada vez mais com tintes independentistas foi assumido por José María Morelos que deu uma virada nacionalista ao movimento. Após a sua captura e fuzilamento a revolta viraria uma guerra de guerrilhas prestes a ser derrotada pelo exército realista até que, em uma manobra política e militar, o líder realista Agustín Iturbide estabelece uma aliança como líder rebelde Vicente Guerrero para consumar a independência e manter os privilégios militares, conservadores e eclesiásticos que estavam ameaçados pelo liberalismo da Constituição de Cádiz. O território seria reorganizado no Império Mexicano, acrescentando os territórios da América Central que se uniriam ao império pouco tempo depois de consumada a Independência (BOERSNER: 1996).

Do anterior é possível perceber o que Guillermo Bonfil Batalla (1990) denomina como "a independência criolla". Não foi de fato um movimento homogêneo, mas além das questões estratégicas e ideológicas que sofreram mudança, as lideranças da revolta estiveram constantemente em mãos dos criollos (Hidalgo, Aldama, Allende, Morelos, Matamoros) que não necessariamente buscavam a emancipação da colônia, como o caso de Hidalgo, mas que ao mesmo tempo buscavam, por exemplo, a abolição da escravidão, como foi proposto por Morelos no primeiro Congresso Mexicano e na declaração formal de independência ${ }^{18}$ (BOERSNER: 1996). Umas situações curiosas são que Morelos dá o nome de "América Setentrional" à nação em lugar de México, a abolição do sistema de castas e a intolerância a

\footnotetext{
${ }^{18}$ Morelos escreve o documento chamado "Sentimentos da Nação" que contém os 23 preceitos que governarão ao país independente, dentre os quais ressalta o número 15: "Que a escravidão se proscreva para sempre, e o mesmo a distinção de castas, ficando todos iguais, e somente distinguirá a um americano do outro o vício e a virtude", (Ver anexo 2). Ao mesmo tempo, se promulga a Ata Solene da Declaração de Independência da América Setentrional em 1813 no Congresso de Chilpancingo.
} 
outras religiões que não sejam a católica. O único momento que a liderança do movimento não ficou em mãos dos criollos foi durante a resistência de um afro mexicano: Vicente Guerrero ${ }^{19}$. A independência tem de ser pensada levando à consideração que, embora se tratasse da independência política de um território enorme em relação ao um Império ainda maior, a população do território não foi participe em igualdade e que de fato o movimento independentista tanto como os ideais reivindicados eram direcionados para o benefício da parcela criolla da população e que, de fato, não se propunha uma revolução radical senão a continuidade da ordem colonial com uma diferença: o exercício do poder passaria dos peninsulares para os criollos. Se no caso mexicano foram elites criollas as que começaram a revolta com apoio popular e só tenha sido possível consumar a independência graças a uma aliança entre rebeldes, aristocratas, elites militares e autoridades clericais, na América do Sul a situação não difere muito, de fato, nos vice-reinos do sul, foram também as elites as que com apoio popular conseguiram se emancipar do domínio europeu; "[...] eran los descendientes de los colonos españoles, colocados en situación de inferioridad frente a los peninsulares" (PAZ: 1999, p. 131).

Poder-se-ia falar que a percepção de alteridade sofreu uma modificação temporária diante da necessidade de criar um sentimento de nação contra o inimigo que estava tentando ser expulso. Os exércitos rebeldes precisavam da participação dos indígenas e outras populações para conseguir fazer frente aos realistas mediante o aproveitamento do "descontento permanente de los indios y de grupos significativos entre los mestizos (BONFIL BATALLA: 1990, p. 148). Porém não quer dizer que tenham sido considerados no projeto da nação que se pretendia ter e muito menos que a percepção da alteridade indígena tenha deixado de gerar mal-estar entre a população branca e mestiça.

Bonfil Batalla argumenta que "la independencia no trajo consigo uma transformación de fondo de la nueva sociedad mexicana" (1990, p. 148) seguindo a linha de pensamento de uma independência criolla- mais do que uma independência da nação mexicana. José Maria Morelos e a Constituição de Apatzingán foi provavelmente a tentativa mais próxima de propor uma nação que pudesse quebrar com a ordem colonial do Império Espanhol. Observando a aliança quase impossível entre conservadores, liberais, rebeldes, clero e exército imperial que

\footnotetext{
19 Vicente Guerrero (1782-1831): Líder da etapa de resistência e consumação da Guerra da Independência mexicana e segundo presidente do México após a queda do Primeiro Império Mexicano e a presidência de Guadalupe Victoria. O encontro com o então general realista, Agustín de Iturbide, conformaria uma impensada aliança entre rebeldes e tropas espanholas que levaria ao Plan de Iguala e a vitória da independência mexicana.
} 
aconteceu no México, seria apenas lógico pensar na busca desesperada para manter os privilégios que se viam ameaçados no coração do Império e a necessidade dos rebeldes de sobreviver ao embate dos exércitos realistas, isto é: não se pretendia modificar a ordem social das colônias, apenas libertar aos criollos do sufoco peninsular (PAZ, 1999).

A nova nação, reorganizada como o Império Mexicano com Agustín I como imperador e um vasto território à sua disposição, devia se auto afirmar diante do Outro internacional. O que antigamente era o Império Espanhol que abarcava o continente de extremo a extremo (amém das divisões administrativas em vice-reinos) se fragmentou em pequenas repúblicas (salvo os impérios mexicano e o brasileiro que não fazia parte do império hispano) e, portanto, começava a busca da identidade nacional e a definição das hegemonias e alteridades intranacionais.

\section{A nação independente e a Revolução}

O Século XIX foi uma época turbulenta para o país. Após consumada a independência em 1821, a nova nação encontrou um território desorganizado e com uma população distribuída de maneira errática, concentrada no centro-sul do país e deixando os territórios do norte praticamente desertos. Encontrou também uma economia destruída por anos de guerra civil, lutas internas pelo poder e um território amplíssimo para controlar.

O império de Agustín I é efêmero e acaba por cair, os cidadãos e grupos políticos republicanos não toleram o "regime ultraconservador" (BOERSNER: 1996; p. 61) e o território se reorganiza em uma federação inspirada no republicanismo dos Estados Unidos (PAZ: 1999). As províncias da América Central declaram a sua independência em relação ao México e se reorganizam como a República Federal da América Central. Posteriormente, produto das lutas internas pelo poder entre conservadores e liberais e a péssima distribuição da população, a federação perde o controle do Texas e, na tentativa de recuperar o território rebelde, entra em guerra com os Estados Unidos e perde a totalidade dos territórios do norte ${ }^{20}$, equivalente à metade do território nacional.

Um momento pivô na história mexicana foi a chegada de Benito Juárez ao poder, um presidente de origem indígena e representante da parcela liberal da política mexicana da época. A proclamação da Constituição de 1857, altamente liberal e anticlerical, provoca a Guerra da

\footnotetext{
${ }^{20}$ O país perdeu os territórios de Alta Califórnia, Santa Fé de Nuevo México e Texas que atualmente fazem parte dos Estados de: Califórnia, Nevada, Utah, Arizona, Colorado, Novo México, Wyoming, Oklahoma e Kansas.
} 
Reforma, uma guerra civil entre liberais e conservadores que culminou com a vitória liberal. A vitória liberal foi curta já que pouco depois os conservadores derrotados apelaram à ajuda das monarquias estrangeiras e, aproveitando a situação, Napoleão III da França invade o país começando a $2^{\text {a }}$ Guerra Franco-Mexicana que levou ao estabelecimento do $2^{\circ}$ Império Mexicano sob o comando de Maximiliano de Habsburgo, imperador de corte liberal contrariamente ao esperado pelos conservadores mexicanos (PAZ, 1999). Finalmente e com o apoio do governo de Lincoln, os franceses são expulsos do território, o imperador é fuzilado e a república é restaurada. Nos anos seguintes, o General Porfirio Díaz chegaria ao poder e se perpetuaria nele por 30 anos até o começo da Revolução Mexicana.

Porém, como foi que o conceito do Outro se desenvolveu no México independente? Foi a manutenção de uma ordem social colonial o qual acabou levando à Revolução 100 anos após o começo da guerra de independência? Temos de lembrar que entre ambas guerras aconteceram guerras internacionais e outros conflitos internos que, em maior ou menor medida, acabaram determinando a ordem social e a diferenciação das alteridades tanto no plano internacional como interno.

Já mencionado anteriormente, a independência representou a ruptura política e administrativa com Madri, mas não foi mesmo uma mudança do sistema burocrático administrativo da colônia em questões internas e muito menos uma mudança social. A sociedade mexicana continuava funcionando mediante a diferenciação de alteridades brancas e não brancas, deixando ao mestiço em um limbo de incerteza e as outras minorias como os negros no esquecimento. Porém a independência da nação mexicana significava isso mesmo, que os habitantes do território eram agora mexicanos e não habitantes de uma colônia do Império Espanhol.

A questão do Outro indígena significava a articulação do mesmo dentro da ideia da nação mexicana para o qual seria necessário "civilizar" às populações indígenas. $\mathrm{O}$ ato de civilizar, segundo Guillermo Bonfil Batalla significa “desindianizar, imponer occidente” (1990, p. 158), o qual poderia até parecer coerente e uma tentativa sincera de integrar à nova nação aquela parcela da população submetida historicamente ao trabalho escravo, porém, atrás da máscara de boas intenções, podemos encontrar o medo e o terror inerentes que a alteridade traz diante de nós.

Civilizar não é outorgar história, não é integrar e não é reconhecer, senão que civilizar é negar o que existiu antes. Civilizar ao índio começa a partir de uma ideia pré-existente que se assume como universal e autêntica (como o ocidente e o cristianismo se assumiam superiores 
diante do índio pré-hispânico), não é um sincretismo senão uma imposição, é a negação da cultura do Outro e, portanto, a negação da existência do mesmo. É o extermínio da alteridade por médio da cultura.

A tentativa liberal de Juárez, segundo Octavio Paz tentou romper a hierarquização colonial sob a premissa de que todos os cidadãos são iguais ante a lei e é uma clara negação do passado de segregação da colônia que “[...] rechaza la tradición y busca justificarse en el futuro” (1999, p. 138). Porém, para conseguir o anterior seria necessário fazer cidadãos daqueles índios, negando não apenas o passado de escravidão que viveram, senão a essência dos mesmos. Fazendo eco com a visão do México profundo e imaginário, Paz percebe a Reforma como o projeto de uma minoria que se desprendeu da maioria religiosa e tradicional e consegue fazer uma definição da nação mexicana que é atemporal: "La nación mexicana es el proyecto de una minoría que impone su esquema al resto de la población, en contra de otra minoría activamente tradicional.” (PAZ: 1999; p. 139).

A permanência da tendência de se diferenciar do Outro permeado pelo medo e a suposta superioridade entre culturas e a necessidade de articular essa diferenciação com os projetos nacionais em nome do progresso demonstra que essa dinâmica social vira uma sucessão de “[...] situações de equilíbrio entre grupos que se combinam e reorganizam para fins de manutenção de novos e mais complexos padrões de interação (...) este padrão atende aos interesses e anseios dos grupos de maneira extremamente desigual ou assimétrica." (SILVA: 2015, p. 8). O Outro índio continua em uma posição de alteridade indesejável e perigosa para dar sentido à continuação da hegemonia de ocidente sobre o México profundo. A hegemonia ocidental se assume universal, portanto para existir tem que estar integrado nela.

A Reforma liberal, embora tenha atacado as estruturas mais conservadoras do país, continuava se assumindo universal como a própria religião católica que pretendia atacar. Paz (1999) descreve essa proximidade e ao mesmo tempo essa diferenciação da seguinte forma:

"El catolicismo fue impuesto por una minoría de extranjeros, tras una conquista militar; el liberalismo por una minoría nativa, aunque de formación intelectual francesa, después de una guerra civil [...] El liberalismo es una crítica del orden antiguo y un proyecto de pacto social [...] Afirma al hombre, pero ignora una mitad del hombre: esa que se expresa en los mitos, la comunión, el festín, el sueño, el erotismo [...] La geometría no substituye a los mitos. Para que el esquema liberal se convirtiese en verdad en un proyecto nacional, necesitaba lograr la adhesión de todo el país a las nuevas formas políticas [...] al fundar a México sobre una noción general del Hombre y no sobre la situación real de 
los habitantes de nuestro territorio, se sacrificaba la realidad de las palabras y se entregaba a los hombres de carne a la voracidad de los más fuertes." (PAZ: 1999; p. 139-140).

O Outro índio, a civilização negada da qual Bonfil Batalla faz referência (1990), não encontrou redenção na independência da nação mexicana em relação ao império que os conquistou três séculos antes, tampouco encontrou redenção na independência nem na Reforma liberal. Encontravam-se dentro da continuação de um projeto de nação ocidentalizado que continuava lhes negando e que agora pretendia exterminá-los através da educação e da imposição cultural. É possível apreciar até o presente momento que a autoafirmação e diferenciação diante do Outro é dirigida pelas necessidades do Estado em determinados contextos históricos. Até agora é possível observar que a categoria índio tem sido a fonte de legitimidade da hegemonia original (os europeus) e as suas redefinições posteriores. O status e concepção do índio como um ser bárbaro, ameaçante e subdesenvolvido dentro do próprio território é não apenas uma fonte de trabalho escravo ou mão de obra barata, senão também uma fonte de legitimidade emanada da evidente superioridade que a hegemonia demonstra e que fabricou desde o momento da conquista.

A inferioridade indígena não foi nem é natural, foi fabricada desde o começo da colônia e mantida através de repetições ritualísticas de segregação e bloqueio das possibilidades de mobilização social. A progressão histórica do Estado colonial para o Estado mexicano manteve a mesma lógica hierárquica colonial para continuar se legitimando como o ente que seria capaz de administrar o território se valendo da alteridade indígena rebelde como a Guerra de Castas em Yucatán ou das rebeliões comanches ou apaches (por mencionar algumas) no norte do país. A Reforma liberal, ao pretender acabar com essa ordem colonial e entrar em uma suposta modernidade, tentou igualar aos cidadãos diante da lei e universalizar o "progresso" sem perceber que, como foi dito, civilizar ao índio é de-indianizar e exterminar as alteridades de forma passivo-agressiva.

Por outro lado, tinha surgido desde a época colonial um novo grupo populacional que representava um limbo entre indígena e europeu (seja peninsular ou criollo): os mestiços. A conquista europeia dos índios e o processo de miscigenação criariam uma ampla gama de castas dentro da colônia que tentariam se auto afirmar diante da diferença das outras castas. Como já foi mencionado, os espanhóis conquistadores se diferenciaram dos índios conquistados em um primeiro momento e, posteriormente, as diferenciações aconteceriam dentro da população espanhola (entre peninsulares e criollos) assim como aconteceria entre a população indígena e 
mestiça. O caso dos mestiços na Nova Espanha representa um particular processo de afirmação da identidade que teve sua origem no binarismo primordial da diferenciação entre europeu e indígena e que, com o decorrer do tempo, acabou se afiançando como o grupo populacional de maior tamanho no México dentro do grande espectro do que ainda restava da "pigmentocracia colonial" burocrática, a qual ao decorrer da época pós-independência se tornou juridicamente irrelevante, segundo afirma KNIGHT (2010, p. 25), mas que continuaria originando grandes consequências sociais ao longo dos séculos XIX e XX.

Os mestiços seriam os próximos em começar a definir a ideia da nação mexicana já que a alteridade que representavam não podia mais passar desapercebida. Em paralelo, o Estado encabeçado por Porfirio Díaz havia assumido o poder e instaurava no país uma espécie de pensamento positivista importado e tropicalizado.

Diaz utilizou as ideias do positivismo de progresso fundado na ciência e na tecnologia. $\mathrm{O}$ objetivo era a modernização do México, mas o processo representava também o sacrifício das classes mais pobres e o enriquecimento das classes dominantes, em outras palavras, o General Diaz governou "inspirado por las ideas en boga: cree en el progreso, en la ciencia, en los milagros de la industria y del libre comercio. Sus ideales son los de la burguesía europea. Es el más ilustrado de los dictadores hispanoamericanos" (PAZ: 1999, p.141). Esse projeto do México imaginário beneficiava às famílias herdeiras do domínio colonial e soterrava as classes inferiores maioritariamente indígenas e mestiços, embora constituíssem a principal força de trabalho nos latifúndios.

Podemos falar da continuação da ordem colonial desde o fim da independência (amém das diferenças, algumas irrelevantes e outras menos irrelevantes, que a Reforma liberal trouxe). O indígena continuava sendo praticamente um escravo enquanto o mestiço, não muito diferente do índio desde o olhar branco, conformava uma proto classe média. A Reforma e a ditadura positivista de Diaz tinham, desde a perspectiva de Octavio Paz (1999), cortado toda ligação do México com o seu passado, era a negação absoluta da profundidade da nação e das alteridades:

\footnotetext{
"La imagen que nos ofrece México al finalizar el siglo XIX es la de la discordia. Una discordia más profunda que la querella política o la guerra civil, pues consistía en la superposición de formas jurídicas y culturales que no solamente no expresaban a nuestra realidad, sino que la asfixiaban e inmovilizaban.” (PAZ: 1999; p. 145)
} 
A Revolução Mexicana começa como uma rebelião proclamada desde o norte do país para expulsar ao General Diaz do poder após uma nova tentativa do último para se reeleger. Francisco I. Madero, pertencente às elites da região, começa a rebelião apoiado pela cidadania, intelectuais e classes medias e operarias em conjunto com as parcelas do campo (BOERSNER: 1996).

O processo revolucionário foi um movimento que, embora tenha sido começado desde uma figura pertencente à percepção do Outro hegemônico, foi uma revolta das alteridades excluídas como a mesma natureza da revolução o demonstra: carente de precursores ideológicos e nula ligação com ideologias universais ou universalizantes (PAZ, 1999). Dentro da própria complexidade do processo revolucionário, especialmente após a deposição e assassinato de Madero e Pino Suárez e a toma do poder pelo General Huerta, é possível apreciar o surgimento de alteridades excluídas representadas pelas figuras dos grandes caudilhos da história não apenas mexicana, senão universal: Emiliano Zapata com o Exército Libertador do Sul e Pancho Villa com a Divisão do Norte.

O pensamento zapatista da época, em maior medida do que o villismo, reivindica a cultura indígena e a sua participação nas instâncias de organização e a tradição cultural que reforça valores de igualdade, dignidade e resistência, assim como relações políticas diferentes das hegemônicas. Esse pensamento posteriormente resgatado pelo Ejército Zapatista de Liberación Nacional - EZLN (MARQUES PEREIRA DOS ANJOS: 2015) se caracteriza pela intenção de voltar às origens, era uma negação da época e da ordem colonial espanhola, da ordem neocolonial de Porfirio Diaz e da Reforma liberal que tinha negado todo tipo de tradição indígena vinculada à posse da terra, o anterior resgatado por Mariategui (2007) no Peru e o problema do índio que tem origem na posse da terra e crítica as tentativas institucionais, burocráticas ou meramente administrativas para tentar resolvê-lo.

No meio da guerra de facções da fase "final" da revolução, surge o componente operário urbano, representados pelo constitucionalista Venustiano Carranza e rapidamente intenta impor o domínio sobre os camponeses de Villa e Zapata. Emiliano Zapata insistia em uma profunda e radical reforma agrária para acabar com o latifúndio e estabelecer cooperativas camponesas (BOERSNER, 1996). É possível apreciar nesse momento, além da revolta das alteridades que já tinha mencionado, a fragmentação das mesmas seguindo já não parâmetros raciais, senão socioeconômicos e geográficos: "[...] é a luta do campo contra a cidade [...] a classe média urbana e também os sindicatos de operários apoiavam a Carranza, enquanto que Zapata era seguido pela classe mais pobre, oprimida e numerosa: os camponeses, maioritariamente 
indígenas" (BOERSNER, 1996; p. 156). Ambos os caudilhos são derrotados e o projeto operário de Carranza consegue se impor; a Constituição de 1917 é promulgada em um 5 de fevereiro.

De novo é necessário lembrar que a diferenciação diante da alteridade não é pura e, como é possível apreciar no caso da revolução, não tem que seguir necessariamente padrões raciais ou culturais. As alteridades no momento da revolução se diferenciaram entre elas pela posição no aparelho econômico de produção e pela geografia, não houve uma distinção estrita entre mestiços, europeus ou indígenas. Porém, cabe se perguntar: por que se deu a divisão e luta entre facções que no fundo estavam buscando o mesmo objetivo? Em que lugar ficaram as elites durante esse processo? A resposta encontra-se no projeto pós-revolucionário e a institucionalização da revolução.

Com tudo, a Revolução Mexicana foi a explosão das alteridades como Octavio Paz (1999) o insinua ao dizer que foi uma imersão do México na sua própria essência, não tanto uma volta às tradições já que elas sempre foram praticadas mesmo na clandestinidade, senão a reaparição das mesmas no cenário público, a aparição do Outro submetido na vida pública, armado, violento e sublevado contra a hegemonia encarnada em um primeiro momento pelo General Diaz, pelo exército federalista e por Huerta: “[...] la explosión revolucionaria es una portentosa fiesta en la que el mexicano, borracho de sí mismo, conoce al fin, en abrazo mortal, al otro mexicano" (PAZ: 1999; p. 162). Foi, como disse Paz, o encontro violento e mortal entre os distintos Outros.

\section{O regime nosso de cada dia}

\section{A revolução institucionalizada}

A Revolução mexicana trouxe consigo a Constituição de 1917, considerada progressista para o momento e que serviria de base para outras constituições latino-americanas e para a mesma carta magna da União Soviética. Tratava-se de uma constituição que reafirmava o controle estatal sobre os recursos do país, rejeitava o imperialismo e que "não apenas reconhece os 
direitos tradicionais, liberais, do homem e do cidadão, senão que enumera seus direitos sociais ao trabalho, à terra, e a uma vida material digna e a previdência social" (BOERSNER: 1996; p. 157). Essa constituição seria o emblema do aparente triunfo da revolução pelos próximos 100 anos, embora seja necessário aclarar que foi apenas o triunfo da facção carrancista da revolução, o triunfo da parcela operária - sindical por encima dos camponeses, embora alguns preceitos agrários tenham sido incluídos na constituição.

A complexidade da revolução, as distintas facções que lutavam entre si e os ideais divergentes que floresceram foram " [...] conciliados, eliminados o, en todo caso, obligados a encuadrarse dentro de um nuevo esquema unificado del poder nacional[...]”" (BONFIL BATALLA: 1990; p. 161). Os turbulentos momentos logo após o triunfo da facção carrancista trouxe uma série de pronunciamentos e a consequente instabilidade da instituição presidencial, em conjunto com a instabilidade e fraqueza do nascente governo carrancista que deu lugar ao surgimento de caciques locais tanto civis como militares que evidenciavam a profunda fragmentação que a revolução tinha deixado, situação que se torna evidente com a infinidade de sindicatos e de partidos políticos ${ }^{21}$ que reivindicavam ideais revolucionários cada um desde a sua trincheira, assim como a força que o próprio Exército representava e a dissenção dos Cristeros $^{22}$ (SALMERÓN SANGINES, 1999). O assassinato de Álvaro Obregón ${ }^{23}$ na Cidade do México provocaria uma crise que comprometia "[...] el único principio de unidad y estabilidad conocido en la tradición política, el único elemento de cohesión en una sociedad políticamente fragmentada y sin tradiciones institucionales ni democráticas" (SALMERÓN SANGINES 1999; p. 12) com o potencial de virar uma nova guerra civil. Para evitar o anterior, os atores políticos do momento, liderados por Plutarco Elías Calles, começariam a transição da revolução e os seus caudilhos para a institucionalização da mesma.

\footnotetext{
“El Partido Nacional Revolucionario tendría como funciones la unificación de los revolucionarios, la solución civilizada de las luchas por el poder, y el tránsito hacia una vida política institucional. En ese sentido, la construcción del partido y la paralela centralización del poder en torno a la figura presidencial fueron la clave que permitió erradicar la dispersión del poder y el
}

\footnotetext{
${ }^{21}$ Partido Liberal Constitucionalista - PLC, Partido Nacional Cooperatista - PNC, Partido Laborista Mexicano PLM, Partido Nacional Agrario - PNA (Salmerón Sangines, 1999; p18).

${ }^{22}$ Os Cristeros eram sacerdotes e civis católicos sublevados (1926-1929) contra o governo anticlerical de Elías Calles e os preceitos da Constituição que proibia aos ministros de culto de participarem ou serem eleitos para cargos públicos, proibia o exercício do culto religioso fora dos templos, proibia a Igreja de possuir bens, assim como proscrevia o uso de vestimentas sacerdotais em público.

23 Álvaro Obregón (1880-1928) Militar, líder político da revolução e presidente do México de 1920 a 1924 por parte do Partido Laborista Mexicano - PLM.
} 
personalismo caudillista, y transitar hacia la institucionalización de la vida política. Al mismo tiempo, se dio el curioso caso de un partido único no totalitario; un partido antidemocrático con vocación democrática" (SALMERÓN SANGINES: 1999; p. 208).

O novo partido devia ser inclusivo para criar uma sólida base popular que o legitimasse através da institucionalidade contraposta ao "país de caudilhos" que a revolução tinha criado. Tratavase de um partido que incluísse todas as facções revolucionárias e que não deixasse lugar à dissenção nem, para todos os fins, à alteridade, é o começo da "dominação legal" dos revolucionários (SALMERÓN SANGINES, 1999). A ideia da dominação legal de um único partido que representasse à revolução institucionalizada começou a sua existência de jeito contraditório ao virar o “instrumento pessoal (de Calles) para impor o seu poder sobre o presidente e os sucessivos presidentes, única maneira de perpetuar o seu poder embora fosse dando-lhe uma máscara institucional" (SALMERÓN SANGINES: 1999; p.32). Desde já podemos observar o caudilhismo disfarçado de institucionalidade que iria determinar a linha de ação do PNR durante os próximos anos.

Recapitulando um pouco, a nova ordem nacional seria fundada no nascente Partido Nacional Revolucionário - PNR que unificaria e integraria às distintas facções revolucionárias, aos caciques civis e militares e a significaria a substituição dos antigos grupos porfiristas no poder, grupos remanescentes do período colonial e do primeiro século do México independente, em favor dos chefes dos exércitos revolucionários, em uma primeira instância, e posteriormente em favor do setor empresarial privado e dos líderes operários e camponeses que trilharam seu caminho mediante o crescente poder dos sindicatos (BONFIL BATALLA: 1990).

Se bem as intenções do PNR não eram as de virar um único partido totalitário ${ }^{24}$ e sim as de criar uma sociedade democrática que funcionasse através da pluralidade essencial da nação mexicana que foi evidenciada na complexidade do processo revolucionário (SALMERÓN SANGINES: 1999), o caudilhismo inerente ao Maximato $^{25}$ de Plutarco Elías Calles e os remanescentes da ordem colonial e porfirista continuava sendo parte da genética política mexicana. As oligarquias hegemônicas, como foi mencionado, não foram erradicadas senão apenas integradas no

\footnotetext{
${ }^{24}$ Como no momento o eram a Falange Española de las JONS de Francisco Franco, o Nationalsozialistische Deutsche Arbeiterpartei - NSDAP de Hitler, o Partido Nazionale Fascista - PNF de Benito Mussolini ou o Partido Comunista da União Soviética - KPSS.

${ }^{25}$ Maximato: É uma etapa histórica e política que começou em 1928 e abarcou as presidências de Emilio Portes Gil, Pascual Ortiz Rubio e Abelardo L. Rodríguez; se caracterizou pela submissão dos mencionados e do aparelho político aos designios de Plutarco Elías Calles, considerado o chefe máximo da Revolução. Terminou com a chegada ao poder de Lázaro Cárdenas em 1934.
} 
aparelho de governo pós-revolucionário e, portanto, a concepção das alteridades assimétricas que foi inaugurada na conquista conseguiu sobreviver à Revolução e a revolta dos Outros oprimidos para integrar-se no regime do PNR.

É claro que, para sobreviver, o Outro hegemônico precisou de ceder a imagem pública de dominação em favor do Outro oprimido que conseguiu tomar o poder após a revolução, porém, a revolta dos Outros oprimidos significou também a fratura dessa categoria e a instauração do domínio do Outro ex-oprimido sobre os restantes que ficaram na opressão. O novo regime é um mutante que não diferenciava mais aos Outros que faziam parte do regime por questões puramente raciais nem a posição dentro do aparelho econômico de produção, senão que faz que alteridades antigamente opostas consigam conviver no poder mediante um pacto de união nacional diante do Outro estrangeiro e um pacto interno para compartilhar o botim do poder.

O regime do PNR precisaria, portanto, de legitimar-se como o guardião dos ideais da revolução das alteridades e da institucionalização da vida revolucionária. Esse esforço seria direcionado à recuperação da identidade nacional profunda mediante a exaltação da mestiçagem entre o europeu e o indígena, a recuperação das tradições e crenças tanto pré-hispânicas como do sincretismo que ocorreu com a cultura europeia. Isto é a criação de uma nação através do sentimento ufanista. O distanciamento do europeísmo positivista de Porfirio Diaz e o liberalismo universalizante da Reforma em favor da exaltação da mestiçagem de duas raças se perfilava de jeito integrador entre o México profundo e o México imaginário.

\section{O nacionalismo que legitimou a ditadura}

Por que um partido único e autoritário com tendências antidemocráticas, mas com supostas intenções democráticas, inclusivo e nacionalista foi tolerado pela população? Em que momento o partido abandonou qualquer vocação democrática e virou uma ditadura não declarada abertamente? Ou, mais importante, como conseguiu se manter no poder por 70 anos sem interrupção dentro de um sistema aparentemente democrático?

Pois bem, é necessário em primeiro lugar entender a face "inclusiva" do partido da revolução desde a perspectiva das alteridades que pretendia integrar. Já foi mencionado que o partido foi criado com a intenção de unificar os revolucionários triunfantes para acabar com as lutas internas e começar a prática política e pública dos ideais da revolução. Foi mencionada também a transição do caudilhismo revolucionário para a institucionalização da revolução. O processo 
de incluir à grande família revolucionária em um único partido criava exatamente isso: um regime democrático no qual apenas um único partido é legitimo por representar com a sua essência à revolução triunfante e, por consequência lógica, qualquer outro partido teria que ser ilegítimo e contrarrevolucionário, embora não o fosse mesmo. Desde já podemos observar a simulação democrática na qual o partido da revolução iria funcionar.

\footnotetext{
“[...] el partido se convirtió en Revolución Institucional, el sistema político mexicano había alcanzado su forma más acabada y entraría en su era dorada, en la época de su dominio político incontestable, el milagro, la paz priísta y todo lo demás. Las masas habían sido convertidas en el firme soporte de un régimen en el que no tenían ninguna capacidad de decisión, y de un sistema político autoritario, eficaz y disciplinado." (SALMERÓN SANGINES: 1999; p. 211).
}

Antes de aprofundar no paradoxo mexicano do surreal -sistema político democrático de partido único-, é necessário entender a estratégia de articulação das alteridades e da diferença que o agora Partido Revolucionário Institucional - PRI utilizou para não apenas representar à revolução triunfante, senão para virar a encarnação institucional de uma raça e de uma nação.

Para entender o conceito de nacionalismo temos de falar ao mesmo tempo de Estado e território. Ambos coexistem em direta relação de dependência, isto é, as condições que definem as características peculiares de um grupo populacional em um território são reunidas, organizadas e manipuladas pelo Estado para criar um monumento discursivo que vai definir a ideia nacional desse grupo e o uso que darão ao território: o pensamento nacionalista é produto de um planejamento político (O’FARRILL: 2010).

Além do mais, o fantasma ditatorial esteve sempre presente desde o momento que o partido único assumiu o labor de criar a ideia de nação e a ideia de mexicano através do maniqueísmo nacionalista próximo do determinismo ideológico totalitarista da ligação intima entre a população, o território e o espaço em questão em um nível quase biológico, como é apontado por Jacques de Novion (2009, p. 47) de acordo com as ideias propostas por Friedrich Ratzel e a geopolítica alemã de final do século XIX e começo do XX. Desde esta perspectiva, o próprio determinismo do território sobre a população e as identidades nacionais geradas a partir do uso do mesmo já funciona como justificativa natural para a instauração de um Estado forte e centralizador que se encontra por cima do indivíduo e da sociedade, já que a existência do Estado, por sua vez, depende da coesão territorial derivada dos "liames espirituais" da 
população, o solo e o Estado que governa e, portanto, é este último quem deve assumir o labor de conservar essa união para assegurar a sua existência continua. (COSTA: 1992, p. 34).

A dissenção de grupos localizados dentro do território nacional através de conflitos étnicosculturais próprios de uma plurinacionalidade é o inimigo máximo do Estado forte e centralizador proposto por Ratzel ao ameaçar diretamente o grande tecido dos "liames espirituais" da supra-nação, ou a ideia do México como uma única nacionalidade por cima de regionalismos fragmentadores (COSTA: 1992, p. 35). Portanto, o combate a essas alteridades dissidentes seria labor vital do Estado forte e homogeneizador a partir da manutenção de um binômio nacional do desejável e indesejável definidos a partir da única ideia de nação do Estado mexicano através da -materialização- do pensamento nacionalista que se alimenta da união espiritual do povo para com o território.

Portanto, se as peculiaridades de um povo em relação com o território são produto natural do uso do próprio espaço, cria-se uma entidade metafísica que Johan Gottfried Herder chamaria de Volkgeist ${ }^{26}$ ou o espírito do povo. Esse espírito existe per se de uma maneira subjacente e metafísica, a sua presença não é invocada diretamente usando termos universalizantes do povo em questão, como seria invocar o mexicano, o alemão, o brasileiro, etc., senão que ele se manifesta na prática cotidiana das ações que são ligadas ao uso do território em particular, logo, é o Estado quem reúne e dá um nome a essas ações cotidianas, exalta elas e as eleva ao nível de essência nacional através da repetição ritualística de atos patrióticos.

A criação do pensamento nacionalista é um eco ou mesmo uma progressão da diferenciação da alteridade e da autoafirmação diante do Outro. O pensamento nacionalista não se cria de forma autônoma, não é puro e responde às necessidades do contexto sócio histórico e econômico. Porém, existe uma diferença fundamental com a criação de alteridades primordiais durante a conquista, colônia ou até no processo de independência: nesses eventos se tratou da criação da alteridade abertamente oprimida dentro da sociedade à qual pertence, a sua função dentro da sociedade não é vedada senão que a função de ser oprimido é abertamente declarada. Por sua vez, o pensamento nacionalista integra todas essas alteridades como membros de uma nação da qual todos fazem parte e todos a fazem existir, portanto, cada grupo populacional tem a missão

\footnotetext{
${ }^{26}$ Volkgeist: O "espírito do povo" seria uma oposição ao universalismo abstrato e uniformizador do pensamento francês revolucionário (COSTA: 1992, p. 31); a oposição radica na variedades e peculiaridades de cada povo (volk em alemão) entendendo-o, segundo BERECIARTU (1988), não como a soma de indivíduos sob um hipotético "contrato social", senão pela união metafisica, abstrata e transcendental gerada a partir da comunhão em uma mesma língua, história, costumes, etc. (geist, ou espirito em alemão).
} 
de manter e proteger a existência da nação e não apenas sustentar o domínio de um Outrohegemônico. A existência de alteridades é condição sine qua non da existência de uma nação.

Porém, como foi mencionado, tanto a criação do nacionalismo como a diferenciação do Outro, não são inocentes nem puros. Se o nacionalismo é criado pelo Estado, pode se afirmar que é criado também pela hegemonia. É necessária a intervenção das elites para articular o que definirá a nação e a função de cada alteridade dentro da mesma (O'FARRILL: 2010). No caso do México quem iria definir a ideia nacional era o Partido Revolucionário Institucional, reduto das elites pré-revolucionárias que sobreviveram a guerra e que agora conviviam e partilhavam o poder com outros grupos que se fragmentaram de antigas alteridades oprimidas para assumir uma posição hegemônica.

A nova ordem estatal e os novos participantes tinham um amplo território que controlar e uma quantia importante de recursos naturais à sua disposição. $\mathrm{O}$ controle do uso do território necessariamente tinha que visar controlar as atividades e as ligações culturais da população para com a terra e, portanto, o novo regime deveria "[...] expropiar o crear los elementos culturales indispensables para la formulación de la instrumentación de su proyecto nacional" (BONFIL BATALLA: 1990; p. 163).

Para o partido era importante se assumir como e monopolizar a representação da revolução triunfante para criar um sistema de simulação democrática que o dotasse de legitimidade pelo simples fato de existir. Era o partido da revolução e da nação que era eleito livremente pelo povo em um simulacro democrático. Porém, o PRI não poderia cometer o erro do liberalismo juarista da Reforma e se assumir com o universal e universalizante diante de uma nação de tão complexa profundidade. Portanto, o partido começou um intricado esquema de criação de uma ideia nacional que integrasse ao passado pré-hispânico (México profundo) e ao passado europeu tendo ao maior grupo populacional (os mestiços) como resultado de essa miscigenação. Outorgava valor histórico ao indígena sofrido e ao europeu conquistador porquê de essa mistura nasceria o mestiço mexicano, este seria uma raça única que por consequência poderia se auto afirmar diante do Outro-estrangeiro e definir a nação mexicana.

A questão nacional do México devia ser respondida a partir das peculiaridades que caracterizam à chamada nação mexicana. Diante de um país racial e culturalmente diverso era necessário encontrar um eixo articulador que unisse as alteridades tanto hegemônicas como oprimidas sem necessariamente estabelecer um regime de igualdade e simetria social. Trata-se de uma proposta 
universalista, porém universalizante e um simulacro de reconhecimento da alteridade para manter as relações assimétricas entre o hegemônico e o oprimido.

O eixo articulador das alteridades nacionais foi encontrado na origem indígena da nação e o sincretismo com a cultura trazida da Europa para conseguir dar forma e nome à manifestação metafísica da ideia do mexicano se valendo de elementos em comum como a língua (castelhana no caso), a história em comum da nação (eventos históricos oficiais do regime tais como: a conquista, a independência e a própria revolução), a religião ${ }^{27}$ (representada, por exemplo, pela Virgem de Guadalupe) e costumes da vida cotidiana (COSTA, 1992).

Por sua vez, o pensamento nacionalista do regime fez evidente uma sorte de esquizofrenia que tinha acompanhado à sociedade desde o primeiro contato com os europeus e o choque civilizatório que aconteceu e, portanto, seria válido perguntar como que o regime conseguiu de fato reivindicar aos grandes índios do passado e as civilizações antigamente consideradas como os derrotados e destinados ao trabalho escravo e a marginalidade em uma sociedade que ainda os considerava dessa forma e, ao mesmo tempo, fazer que dita sociedade se sentisse orgulhosa de reivindicar um passado índio e em paralelo continuar vendo aos índios como um Outroindesejável, porém, mexicanos.

A resposta poderia ser encontrada dentro de um labirinto de contradições e negações da esquizofrenia da sociedade mexicana. Um indígena é mexicano só que do mais baixo nível, mas ao mesmo tempo as civilizações pré-hispânicas atingiram níveis de desenvolvimento importantes, e isso faz sentir orgulho e parte de uma nação. Por que pensamos assim? Existe uma tendência intrínseca de detestar ou menosprezar o que é indígena e distante de nós? Os índios são aqueles que foram derrotados pelos espanhóis e que não são dignos herdeiros das antigas civilizações mesoamericana, são aqueles que ainda carregam o estigma de terem sido os escravizados da colônia.

O índio aparece na concepção do mexicano como um ser bipolar: um poderoso guerreiro do passado e um marginal do presente sem futuro; as ruinas das antigas cidades pré-hispânicas reforçam a primeira imagem enquanto a miséria do presente reforça a segunda. $\mathrm{O}$ regime teria que eliminar a segunda mediante o seu desaparecimento por via da ocidentalização já não havia

\footnotetext{
${ }^{27}$ Embora o regime tenha sido abertamente anticatólico, a criação do mito da Virgem de Guadalupe pode ser visto, segundo Mauricio Pilatowsky, como parte do processo colonizador do imaginário mexicano ao fundir em uma imagem só à virgem católica e à deusa mexica Tonantzin - La Virgen de Guadalupe em la colonizacion del imginario mexicano - Mauricio PILATOWSKY, publicado em 15 de setembro de 2010, disponível em: http://mauriciopilatowsky.blogspot.com.br/2010/09/la-virgen-de-guadalupe-en-la.html - acessado em maio de 2016.
} 
lugar para alteridades miseráveis fazendo função de fardo. Porém a ocidentalização seria repetir o erro liberal universalizante, portanto, em aras de criar uma nação homogênea entre um mar de nações heterogêneas, o apelo do regime foi para uma visão salomônica da raça: espanhol + índio = mexicano mestiço. Aqueles que não o fossem deviam ser integrados quanto antes (BONFIL BATALLA: 1990; p. 164) e, para dar legitimidade, ou pelo menos um consolo ao fato de - redimir ao índio por via da sua desaparição -, se "reconheceu" oficialmente o seu labor como pilar fundamental na criação do mexicano. O discurso oficial do regime sobre a miscigenação e da nossa herança hispânica priorizava a exaltação dos grandes índios do passado como Cuauhtémoc e Moctezuma e aparentava reivindicar às civilizações soterradas pelo domínio espanhol e criollo. As grandes pirâmides, os avanços científicos das antigas civilizações e os índios pré-hispânicos são glorificados enquanto os do presente ficam à margem do projeto de nação e sujeitos a políticas sociais de extermínio cultural como o indigenismo:

\begin{abstract}
“[...] el indigenismo contradice en nada el proyecto de país que la Revolución triunfante ha ido cristalizando: se trata de incorporar al indio, es decir, desindianizarlo, hacerlo perder su especificidad cultural, histórica. El asunto es como hacerlo mejor. Para (Manuel) Gamio ${ }^{28}$ el camino es claro: 'Para incorporar al indio no pretendamos europeizarlo de golpe, por el contrario, indianicémonos nosotros un tanto, para presentarle, ya diluida, en la suya, nuestra civilización, que entonces no encontrará exótica, cruel, amarga e incomprensible. Naturalmente que no debe exagerarse a un extremo ridículo el acercamiento al indio." (BONFIL BATALLA: 1990; p. 171-172).
\end{abstract}

$\mathrm{O}$ anterior remete à necessidade do regime de espalhar o seu discurso nacionalista homogeneizador por médio da educação pública. José Vasconcelos seria o agente do regime que teria o labor de fundar a nova educação pública "no sangue, na língua e no povo" (PAZ: 1999; p. 164) como Ministro de Educação Pública e reitor da Universidade Nacional Autônoma do México - UNAM, isto em conjunto com outras grandes áreas culturais que se volcaram em apoio total ao regime, tais como pintores, muralistas $^{29}$, arquitetos, músicos, etc., os que Octavio Paz chamaria de "inteligência mexicana".

\footnotetext{
${ }^{28}$ Manuel Gamio (1883-1960): Antropólogo, arqueólogo e sociólogo. Autor do livro "Forjando Pátria (Pro nacionalismo) ", obra amplamente usada para difundir o discurso nacionalista do regime pós-revolucionário em aras de criar uma nação homogênea e unida.

${ }^{29}$ Movimento caracterizado pela exaltação de passagens da história mexicana e de heróis, principalmente revolucionários (como Zapata, ironicamente assassinado pelos próprios revolucionários), independentista, indígenas e figuras da guerra contra a França e os Estados Unidos. Contêm temática relacionada à miscigenação, ao campo e à classe operaria e, por momentos, muito próxima de figuras comunistas (por exemplo: "El Hombre Controlador del Universo" de David Alfaro Siqueiros). Os principais exponentes são: Diego Rivera, David Alfaro
} 
A educação pública se espalhou pelo território, abrindo escolas e bibliotecas com uma evidente tendência nacionalista no conteúdo. O labor dos outros membros da "inteligência mexicana" seria selecionar, como foi mencionado, certos aspectos e características da população mexicana, tanto nos seus hábitos no uso do território e as tradições a eles ligados, como passagens emblemáticas da história (cuidadosamente selecionadas) para criar tradições comuns à população mexicana no geral e criar mitos de origem, principalmente indígenas e mestiços.

Vasconcelos pública posteriormente a sua obra mais conhecida, "A Raça Cósmica” (1925) na qual dedica páginas à criação de um Outro-estrangeiro mas não apenas em um nível nacional, senão que o cria em um nível civilizatório ao contrapor à civilização Hispano-latina contra os anglo-saxões, fazendo ênfase na necessidade da miscigenação dos índios com o espanhol mas sempre com uma clara tendência europeia. Na obra, os índios ficam relegados, reconhecidos sim, porém sujeitos à miscigenação para serem aperfeiçoados pelo sangue hispano e, finalmente e de maneira delirante, propõe o surgimento da Quinta Raça Cósmica, resultado da miscigenação universal dizendo que no "[...] suelo de América hallará término la dispersión, allí se consumará la unidad por el triunfo del amor fecundo, y la superación de todas las estirpes. " (VASCONCELOS: 1925; p. 15).

O grande fracasso da tentativa civilizatória através da criação do pensamento nacionalista encontra-se na falácia essencial que o anterior representa. Já foi mencionado que o pensamento nacionalista é artificial de origem ao ser produção do Estado e do Outro-hegemônico a partir de elementos legítimos da relação entre um povo e o seu território. O projeto nacionalista se apresenta como integrador e reconhece a diversidade de alteridades que originaram, compõem e mantêm a existência da nação, porém, continua sendo uma construção de uma elite que é imposta ao restante da população. Guillermo Bonfil Batalla ataca diretamente a falácia nacionalista do PRI argumentando que a nação mestiça que o partido tentou criar não é nem legítima nem viável.

\footnotetext{
“[...] se admite que hay valores positivos en la civilización mesoamericana que deben incorporarse al proyecto nacional y se postula la fusión de civilizaciones como la vía para crear una autentica cultura nacional (y, por tanto, un proyecto nacional legítimo y viable). En páginas anteriores, he intentado mostrar la falacia de lo que he llamado la cultura mexicana "mestiza"; no insistiré en ese punto. Pero si conviene recordar que la integración e dos o más culturas distintas para formar una nueva es un proceso posible, pero de muy larga
}

Siqueiros, Gerardo Murillo (Dr. Atl), José Clemente Orozco, Rufino Tamayo, Roberto Montenegro, Federico Cantú, Juan O’Gorman e Pablo O’Higgins. 
duración histórica. Los factores que conducen a la cristalización de una nueva cultura no están sujetos a la voluntad de los individuos sino que resultan de amplios procesos sociales en los que intervienen sucesivamente varias generaciones. La fusión de las culturas y civilizaciones que coexisten en México puede ocurrir, pero lo seguro es que no ocurrirá en un futuro previsible y, desde luego, no será el resultado de un decreto ni de las acciones de una o dos generaciones.” (BONFIL BATALLA: 1990; p: 231-232).

Portanto, o nacionalismo do regime é uma continuação da ordem de dominação das alteridades com a particularidade de que o regime pós-revolucionário redefiniu as caraterísticas de um Outo dominador e de fato foi integrador e inclusivo. O Outro-hegemônico não era mais definido exclusivamente pela raça, origem ou posição socioeconômica, senão pela posição dentro do regime e as conexões intra-partido para manter o domínio autoritário da revolução institucionalizada e, em paralelo, o Outro oprimido sofreu uma diversificação das características consideradas indesejáveis e extermináveis dependendo da necessidade do momento: as alteridades continuam à mercê da minoria hegemônica.

O regime pós-revolucionário, que transitou rapidamente de uma revolução legítima das alteridades oprimidas a um regime autoritário, tinha criado a sua própria ideia de nação fabricando heróis e vilões através da sua historiografia oficial ${ }^{30}$ e pregava o discurso da união nacional por encima de qualquer divergência. Porém, havia um perigo que não foi percebido com tempo suficiente como para detê-lo, em parte pelo fervor ufanista da suposta revolução popular triunfante e da propaganda dos agentes do regime como José Vasconcelos. Esse perigo era o fato do partido único estar criando unilateralmente a ideia de nação sob o comando do Outro-hegemônico, além do mais, era a criação de uma ideia de nação altamente abstrata e interpretável.

\footnotetext{
${ }^{30} \mathrm{O}$ regime criou a sua própria mitologia matizando personagens e períodos históricos de forma que a Revolução e o regime se auto justificavam como a divisa entre uma época de barbárie e a modernidade do país. Os eventos históricos de luta pelo poder e lutas internas, marcados por períodos de violência extrema, são "maquiados" e reconstruídos nos livros de história do sistema de educação pública para que as vitorias sejam interpretadas como o triunfo do amor à pátria e as derrotas sejam vistas como a queda estoica dos nossos heróis. A intenção é também demonstrar que a união de forças divergentes pelo bem da nação mexicana é a força que mantem ao país funcionando, exemplos do anterior é a união entre Vicente Guerrero e Agustín de Iturbide para consumar a independência; por um lado temos o romance de uma união impossível impulsada pelo fervor patriota e, por outro lado, uma união estratégica para um manter os privilégios de sempre e para o outro não morrer junto com os seus soldados rebeldes - Exlusión y violencia en la configuración de los imaginarios mexicanos - Mauricio PILATOWSKY, publicado em 29 de outubro de 2011, disponível em: http://mauriciopilatowsky.blogspot.com.br/2011/10/exclusion-y-violencia-en-la.html - acessado em março de 2016.
} 
A criação unilateral do mexicano e as características que deveriam ser constituintes do mesmo, portanto, facilitam a criação de alteridades indesejáveis que podem ser adjudicadas a qualquer tipo de dissidência que ameace a hegemonia daqueles que estão no comando da Revolução Institucionalizada e que não participam da simulação democrática. O Outro indesejável não tem mais um esquema estável de diferenciação, senão que todos somos Outros indesejáveis em potência. Qualquer categoria social ou característica de um setor populacional pode virar um estigma antagônico ao regime e à nação mexicana: ser estudante, operário, sindicalista, branco, moreno, comunista, anarquista, loiro, negro, etc. A questão é quem define isso e para que o faz?

\section{$O$ regime atual}

O regime havia conseguido se afiançar no domínio e, com o passo do tempo, naturalizou a sua presença permanente no poder; a intenção seria fazer do México um país “[...] industrial, moderno, urbano y cosmopolita [...] " aproveitando o impulso que a Segunda Guerra Mundial deu às economias periféricas através da substituição de importações e o chamado "milagre mexicano" (BONFIL BATALLA: 1990; p. 177). A aparente estabilidade econômica do país outorgava ainda mais legitimidade ao regime e a população tolerava a simulação democrática institucionalizada.

O anterior resulta curioso quando falamos de um regime revolucionário que transitou para uma ditadura evidente que pretendia (e ainda pretende) se ocultar atrás de uma máscara de simulação democrática. Mais importante ainda, lembrar que foi o PRI aquele que definiu o que é ser mexicano e se assume como a encarnação institucional da nação tendo poder absoluto na definição do que é ser um Outro-indesejável. O regime atual continua sendo um Estado negador de grande parte da essência da nação embora tente se disfarçar com a falácia nacionalista mediante a expropriação do passado e identidade indígena, fazendo deles um " [...] patrimonio común de todos los mexicanos, aunque esa adopción no tenga ningún contenido profundo y se convierta solo en un vago orgullo ideológico por lo que hicieron 'nuestros' antepasados", (BONFIL BATALLA: 1990; p. 186).

Um fenômeno interessante e característico do regime do PRI é a veneração da instituição presidencial, consequência do caudilhismo primordial que deu origem ao PNR de Elías Calles. Logo, o Presidente da República é, não apenas o titular do poder executivo, senão o líder de uma nação, da revolução que deu origem ao país atual, dos ideais que representa e o líder do partido único; é praticamente o imperador da nação revolucionária. 
A corrupção do partido da revolução começou no momento em que se perdeu a noção da classe operaria manter a tutela do Estado. Os favores e o clientelismo emanados da lealdade dos sindicatos para com o governo geraram um campo fértil para a corrupção dos líderes sindicais e dos agentes do Estado e a aliança entre ambos " [...] se convirtió en sumisión y los gobiernos premiaron con a los dirigentes con altos puestos públicos" (PAZ: 1999; p. 193). Os sindicatos viraram mais um componente do PRI e perdeu-se uma parte importante da vida democrática do país.

Porém, e arriscado falar que alguma vez existiu essência democrática em um sistema político originado a partir de um partido único e autoritário. De fato, nunca houve uma tentativa democrática sincera desde o momento que a Constituição de 1917 é feita à medida dos grupos que assumiriam o poder através do PNR. A constituição, dentro do louvado progressismo da época, esconde a arma principal do partido da revolução para assegurar a sua permanência no poder: o sequestro da soberania popular.

O artigo $39^{\circ}$ constitucional $^{31}$ estabelece que a soberania emana do povo e é o povo quem pode alterar a forma de governo quando o considerar necessário. A primeira impressão é aquela de uma vida democrática plena na qual os cidadãos são representados integramente pelos funcionários eleitos, os quais devem render contas ou abandonar o cargo se o clamor popular assim o demandasse. Porém, o artigo $39^{\circ}$ não é mais do que a máscara constitucional da simulação democrática já que os dois artigos seguintes funcionam como contrapeso e o bloqueiam efetivamente. $\mathrm{O}$ artigo $40^{\circ 32}$ constitucional define a organização da nação como uma República representativa e federativa composta por Estados livres e soberanos, mas é o artigo $41^{\circ}$ no qual se sequestra a soberania que supostamente dimana do povo.

\footnotetext{
Artículo $41^{\circ}$ Constitucional: "El Pueblo ejerce su soberanía por medio de los Poderes de la Unión, en los casos de la competencia de éstos, y por los de los Estados, en lo que toca a sus regímenes interiores, en los términos respectivamente establecidos por la presente Constitución Federal y las particulares de los Estados, las que en ningún caso podrán contravenir las estipulaciones del Pacto Federal”.
}

\footnotetext{
${ }^{31}$ Artículo $39^{\circ}$ Constitucional: "La soberanía nacional reside esencial y originariamente en el pueblo. Todo poder público dimana del pueblo y se instruye para beneficio de éste. El pueblo tiene en todo tiempo el inalienable derecho de alterar o modificar la forma de su gobierno."

32 Artículo $40^{\circ}$ Constitucional: "Es voluntad del pueblo mexicano constituirse en una República representativa, democrática, federal, compuesta de Estados libres y soberanos en todo lo concerniente a su régimen interior; pero unidos en una federación establecida según los principios de esta ley fundamental."
} 
De uma forma, totalmente utópica talvez, um povo representado plenamente pelos funcionários votados popularmente estaria, de fato, delegando a sua soberania aos Poderes da União e seria a voz do povo, através da representação política, a que falaria desde as tribunas do governo. Porém, o que pode ser esperado de um sistema "democrático de partido único"? E além do mais, o que esperar quando os preceitos que governam e constituem a nação foram concebidos apenas pelo grupo de revolucionários triunfantes? Pensar que realmente existiu uma vocação democrática do partido da revolução seria inocente pela própria existência do artigo $41^{\circ}$.

\begin{abstract}
"Lo anterior es el deber ser, se lee como si pareciera justo, democrático y enorgullecería a los próceres de la democracia representativa, pero no hay necesidad si quiera de entrar al ser para demostrar el garrafal fallo que habita en nuestro cuerpo legislativo angular. De manera romántica y demagoga, el artículo $39^{\circ}$ consagra la soberanía como instrumento natural del pueblo, pero lo limita a ejercer esta facultad solo a través de los Poderes, dejando abierta la posibilidad de cambiar de forma de gobierno, pero solo a través del propio gobierno (...)".33
\end{abstract}

Portanto, o povo não exerce soberania nenhuma já que, segundo a Constituição e os próceres revolucionários, delegamos a nossa soberania aos nossos representantes nos três Poderes da União. O enorme problema é que esses representantes se encontram totalmente afastados da população e tomam decisões por e para o povo de maneira unilateral. Mas por que não existe proximidade entre o povo e os seus supostos representantes? Lembremos das origens do sistema político mexicano contemporâneo e os momentos fundacionais do PRI. É o partido que reuniu à grande família revolucionaria, mas que assassinou aos representantes da revolução agrária (Zapata e Villa); o partido que aceitou dividir o poder com as oligarquias sobreviventes da ditadura porfirista; aqueles que se separaram do Outro-oprimido, do povo ignorante e pobre para aceder aos postos de poder junto como o Outro-hegemônico em um sistema de dominação histórica no qual o povo não precisa ser representado, senão que precisa ser conduzido e controlado. Representar? Sinceramente, para que? ${ }^{34}$ A representação cidadã não é um paradigma dos distintos governos históricos mexicanos e das nações colonizadas no geral.

\footnotetext{
33 Soberanía Nacional Secuestrada - Alejandro GÓMEZ em La Serpiente Desplumada, publicado em 17 de dezembro de 2014, disponível em: https://laserpeintedesplumada.wordpress.com/2014/12/17/soberania-nacionalsecuestrada/ - acessado em maio de 2016.

34 “[...] la representación distorsionada se ha convertido en la vía más fácil para dominar a la sociedad y evitar la democracia. Esto se hace... presentando, primero, la imposibilidad de la democracia directa (...) y ofreciendo algo que parece muy razonable: la elección de representantes de la población para que lleven a cabo funciones que los ciudadanos les encomiendan. Pero, y aquí reside la trampa (...) muchos países que viven bajo el dominio de las oligarquías, en lo que se llama 'representación democrática', los individuos a quienes los ciudadanos de los distintos poblados creen que eligen como 'sus' representantes, según las leyes y la doctrina: 'no representan
} 
O PRI foi se fortalecendo com o passo dos anos se aproveitando dessa cumplicidade entre a figura presidencial e o Partido assumido nacional, dotados de legitimidade para esmagar à dissidência (PAZ: 1999). Ao mesmo tempo, o sequestro da soberania nacional através de uma constituição fantoche blindava ao presidente de qualquer tentativa de deposição seja cidadã, por meio do congresso (dominado pelo PRI) ou por médio do Judiciário.

Eis o poder absoluto do Partido e do Presidente: o primeiro se assumindo como A Nação e o segundo como o Líder da Nação, da Raça e da Revolução e qualquer pessoa ou grupo antagônica ao projeto do PRI é, por consequência lógica, inimigo da nação mexicana e, portanto, legitimamente exterminável. Não está demais lembrar que no regime atual o Outro é fabricado e selecionado dependendo do contexto e das necessidades do momento.

Provavelmente o caso mais emblemático do extermínio legitimado das alteridades diretamente emanado do Governo Federal e direcionado contra um grupo cuja alteridade foi fabricada é o Massacre de Tlatelolco nas vésperas dos Jogos Olímpicos da Cidade do México em 1968 no marco de protestas estudantis mundiais, mostrando a - universalidade do protesto - desligado das ideologias antagônicas do momento. O movimento, abertamente anti-PRI e encabeçado pelos estudantes da Universidad Nacional Autónoma de México - UNAM e do Instituto Politécnico Nacional - IPN, ameaçava a realização das olimpíadas, criticava abertamente o autoritarismo do partido da revolução e pregava uma palavra proibida para o regime: democratização (PAZ: 1999).

É nesse momento que o aparelho de repressão de uma ditadura comum, encabeçada pelo presidente Gustavo Díaz Ordaz, entra em ação, deslegitimando as demandas estudantis ${ }^{35}$, ligando-os à agentes estrangeiros para desnacionalizar o movimento e poder categorizá-los como Outros-indesejáveis, traidores, estrangeiros, etc., e, dotado da legitimidade que recebe pelo fato de ser a encarnação da nação mexicana, poder exterminá-los na Praça das Três Culturas em Tlatelolco, no norte da Cidade do México, em 2 de outubro de 1968. O número de

ni a los ciudadanos que participan en las elecciones, ni a los habitantes de esos distritos, ni tampoco a la población total del país', y por lo tanto, difícilmente los ciudadanos pueden encomendarles nada a esos individuos, ni éstos tienen obligación alguna para con los ciudadanos" (VALDÉS: 2012, p.13).

${ }^{35} \mathrm{O}$ movimento estudantil demandava: a) Liberdade aos presos políticos, b) Destituição dos generais Luís Cueto e Raúl Mendiola, assim como do tenente coronel Armando Frías, c) Extinção do batalhão de choque, d) Derrogação do Art. 145 e 145 bis do Código Penal, e) Indemnização dos familiares dos mortos pela repressão e f) Deslindamento de responsabilidades por parte das autoridades através da polícia, batalhão de choque e exército Movimiento estudiantil: cronologia del movimento, año 1968 - Arce A, resgatado de Edificios de México, publicado em outubro de 2008 - Fonte: http://www.edemx.com/mas/Mex68/movimientoE.html acessado em 24 de março de 2016. 
$\operatorname{mortos}^{36}$ é incerto em parte devido à cumplicidade da mídia (encabeçada por Televisa) e o desinteresse de grande parte da população mexicana mesmerizada pela ditadura priísta. Porém, uma coisa é clara: o regime criou nesse momento um Outro-indesejável usando atributos préexistentes no imaginário mexicano e mundial (comunista, anarquista, periférico, não-branco, baderneiro, infiltrado estrangeiro, vagabundo, etc.) e enquadrando-os dentro da categoria de "estudante".

\begin{abstract}
"Algunos políticos invocan esa manoseada frase de Heráclito, y exclaman: 'Carácter es destino'. Si no hay carácter, dicen, no tendremos futuro. Hace mucho que Walter Benjamin explicó que si hay carácter el destino es constante y por lo tanto no hay destino. Por ello es importante separar claramente carácter y destino. El primero pertenece a la comedia, el segundo a la tragedia. Cuando México tuvo carácter, vivíamos inmersos en la comedia revolucionaria: no había destino, todo estaba institucionalizado en el eterno retorno al autoritarismo. Ahora, con la democracia, tenemos un destino: pero vivimos sin conocer el final de la obra. [...]" (BARTRA: 2014, p. 15-16).
\end{abstract}

O domínio absoluto do PRI começou a enfraquecer a partir da crise econômica de 1982, provocada pela crise internacional do petróleo, e piorou com eventos posteriores, alguns deles fortuitos, como o terremoto da Cidade do México em $1985^{37}$ e a teimosia para sediar a Copa do Mundo da FIFA em 1986 mesmo com a capital do país em ruinas. O partido começa a ver minada a sua posição como força política hegemônica e a simulação democrática começa a parecer de fato uma possível vida democrática de verdade.

Porém, a grande oportunidade de ter um esboço de vida democrática no país é rapidamente esmagada pela clamorosa fraude eleitoral de 1988 contra Cuauhtémoc Cárdenas, representante da esquerda cismada do PRI pouco tempo antes, e que levou ao poder a Carlos Salinas de

\footnotetext{
${ }^{36}$ A cifra de falecidos é variável considerando os mortos na Praça por parte do Exército mexicano e os assassinados nos blocos residenciais durante as buscas apartamento por apartamento, assim como o silêncio cumplice da mídia. O Consejo Nacional de Huelga - CNH (Conselho Nacional da Greve) reportava 150 pessoas abatidas nos dias imediatos após o massacre; o Governo Federal reporta 26 abatidos e 100 feridos à imprensa estrangeira; o Ministro da Defesa por médio de cartas estabelece 38 civis e 4 militares abatidos; imprensa estrangeira independente reportou 500 falecidos enquanto outros reportaram 325; imprensa nacional especulou entre 200 e 1.500 os abatidos - Los muertos de Tlatelolco - Kate DOYLE em The National Security Archive, publicado em 1 de outubro de 2006, disponível em: http://nsarchive.gwu.edu/NSAEBB/NSAEBB201/index2.htm - Los muertos de Tlatelolco ¿cuantos fueron? - Redaccion Aristegui Noticias, publicado em 1 de outubro de 2013, disponível em: http://aristeguinoticias.com/0110/mexico/los-muertos-de-tlatelolco-cuantos-fueron/ - acessados em março de 2016.

${ }^{37}$ O PRI foi duramente criticado por oferecer cifras oficiais de mortos muito por embaixo de outras cifras não oficiais, assim como pelas poucas aparições públicas do presidente Miguel de la Madrid e a lenta resposta do governo federal em labores de resgate de vítimas e remoção de escombros; por outro lado, muitos dos prédios destruídos evidenciaram a corrupção no controle de construção, pois muitos prédios foram construídos com materiais de baixa qualidade que foram pagos como se tivessem sido de primeira qualidade.
} 
Gortari, presidente que abandonaria de vez o projeto revolucionário nacionalista em favor do sistema neoliberal com a ratificação do Tratado de Livre Comércio da América do Norte TLCAN e o alinhamento com o Consenso de Washington. A antiga ideologia nacionalista do regime não seria mais aquele grande monumento de décadas passadas. $\mathrm{O}$ "erro de dezembro" 38 que levou à crise econômica de 1994 e a insurreição do Exército Zapatista de Libertação Nacional - EZLN no estado sulista de Chiapas levam finalmente à queda do PRI em 2000 em favor do empresário Vicente Fox, representante da direita do Partido Acción Nacional - PAN.

A suposta alternância que a nação tinha conseguido com a vitória do PAN demonstrou ser apenas a alternância de grupos de poder hegemônicos encabeçando o Estado, embora a saída do PRI após 70 anos no poder tenha sido percebida como o que John M. Ackerman denomina como "o mito da transição democrática" o qual, segundo ele, é "[...] uno de los mitos más nocivos, que debilita la movilización social y el desarrollo de una consciencia crítica entre los mexicanos [...] "39 já que a ínfima experiência de vida democrática que temos no decorrer da nossa história é o triunfo de Vicente Fox, não temos parâmetros de comparação com outras conquistas democráticas. $\mathrm{O}$ anterior é sumamente perigoso é foi aproveitado pelo regime para acabar com qualquer tentativa de democratização do país; o governo foxista inaugurou o novo tipo de dominação política após a perda do poder do PRI. A nova lógica seria através do domínio dos partidos políticos entre si: a chamada partidocrácia. A simulação democrática ${ }^{40}$ se fortaleceu com a vitória do PAN em 2000 já que teve apenas uma alternância das cores dos partidos no poder, porém, não existiu alternância política real ${ }^{41}$ nem a possibilidade de ter um candidato triunfante que não seja parte do Outro-hegemônico.

\footnotetext{
${ }^{38}$ Foi o início do colapso econômico de 1994 no México, mas de consequências globais, conhecido na América do Sul como o "efeito tequila"; causou a desvalorização do peso mexicano por mais de $100 \%$, a queda do PIB por $6.2 \%$ e a quebra de bancos e empresas, deixando milhares de desempregados. Aconteceu poucos dias (20 de dezembro de 1994) após Ernesto Zedillo ter tomado posse como Presidente da República quando informação privilegiada de uma "desvalorização controlada" do peso provocou que 4 bilhões de dólares foram retirados das reservas internacionais por alguns quantos empresários especuladores em questão de horas - El "error de diciembre”, inicio de una gran crisis - Ernesto GAZCÓN em Dinero en Imagen, publicado em 20 de dezembro de 2014, disponível em: http://www.dineroenimagen.com/2014-12-20/48207 - acessado em maio de 2016.

${ }^{39}$ El mito de la transición democrática - John M. Ackerman em Soberanía Popular, publicado em 20 de maio de 2014, disponível em: http://soberaniapopularmx.blogspot.com.br/2014/05/el-mito-de-la-transicion-democratica18.html - acessado em maio de 2016.

40 "Hoje as eleições no México não permitem a expressão autentica da vontade popular, senão que são meras cerimonias nas quais os poderes fáticos reafirmam e legitimam o seu controle sobre a política nacional. E somente o observador mais ingênuo poderia pensar que a nova integração do Instituto Nacional Electoral - INE ou a nova reforma eleitoral 'agora sim' resolveriam os graves problemas de ilegalidade, inequidade e fraude institucionalizados" - Ídem.

41 “O indicador mais comum da existência de uma transição democrática é a celebração de eleições libres, limpas e autênticas nas quais as condições de competição são equitativas e a 'oposição' tem possibilidades reais de ganhar as eleições. É evidente que o México não cumpre com este quesito. Todas as eleições presidências celebradas
} 


\begin{abstract}
"México no cumple con los estándares mínimos para ser considerado como un régimen democrático. Por lo tanto, las luchas ciudadanas tendrían que orientarse hacia la transformación integral del sistema de dominación y control que mantiene a más de 60 millones de mexicanos en la miseria y a todos en un total estado de indefensión. No es suficiente cambiar de nombres a las mismas instituciones de siempre o modificar artículos legales que jamás se aplicarán. 42
\end{abstract}

O regime dos nossos dias é um dinossauro das épocas mais jurássicas da nossa história sustentado ainda por monumentos discursivos da superioridade de ocidente por encima do que seja nativo da América. A diferenciação das alteridades feita nos primórdios da conquista do território não oferece mais sentido nem é mesmo aplicável pela própria diversidade da população. Esse processo de enfraquecimento do binarismo índio/europeu foi explicado no decorrer do presente capítulo. Porém, não significa que o caminho esteja levando a um paraíso de convivência pacifica no qual ter nascido índio e pobre não signifique uma desvantagem essencial. O Outro ainda provoca mal-estar e precisamos da autoafirmação diante dele e continua sendo o Outro-hegemônico quem determina isso, sendo que o que mudou foram as características que determinam o que seria um Outro-indesejável.

O fracasso da falácia nacionalista do PRI e a tentativa de criar uma sociedade homogênea permitiu que os Outros-oprimidos tivessem a oportunidade de se auto-afirmarem fora de "sistemas de valores relativamente estables" determinados pelo regime (BARTRA, 2013; p. 39) o qual ameaça a hegemonia do Estado em quanto definição do Outro-indesejável se refere. De esta maneira, a relativa pax priísta é desestabilizada e “[...] la legitimad del gobierno ya no se basa en la vieja tradición nacionalista (...) todavía no se consolida una nueva cultura cívica democrática que estabilice el sistema. Por ello el futuro nos proyecta largas e inquietantes sombras" (BARTRA: 2014, p. 16-17). O mencionado provoca a perda do domínio absoluto que o PRI mantinha sobre a nação e deixa ao PAN com a enorme oportunidade de abandonar o caudilhismo institucionalizado e transitar para uma verdadeira vida democrática.

Após insipido governo do empresário Vicente Fox e em clara traição ao incessante discurso sobre a verdadeira vida democrática que finalmente alcançaríamos e que foi parte essencial da sua campanha eleitoral e posterior administração, o presidente recorre à antiga prática priísta de literalmente entregar a presidência da república ao candidato do partido no poder (no caso o

desde 1988 até hoje tem demonstrado além de qualquer dúvida que os poderes fáticos e as instituições eleitorais de jeito nenhum permitirão a chegada de um verdadeiro candidato de 'oposição' ao poder" - Ídem.

${ }^{42}$ Ídem. 
PAN) deixando ao candidato das esquerdas, Andrés Manuel Lopez Obrador, derrotado por uma mínima diferença em uma contagem de votos cheia de acusações de fraude por parte da esquerda $^{43}$; deixa também ao país polarizado e fanatizado entre esquerda e direita e o poder em mãos do máximo exponente do despotismo do Outro-hegemônico. O governo de Felipe Calderón abraçou os preceitos priístas de definição unilateral da alteridade indesejável ao inaugurar a guerra contra as drogas como a panacéia da luta pelos "bons costumes e valores do México ocidentalizado", incendiando o país no processo. O Estado mexicano agora tem que fazer frente ao monstro de mil cabeças que é o narcotráfico e à dissidência não mais silenciada dos Outros-oprimidos provocada pela saída do PRI do poder.

\footnotetext{
"En la época de la comedia revolucionaria dominaba el carácter autoritario de una identidad nacional permanente. Con la llegada de la tragedia democrática aparece una multitud de caracteres contradictorios y cambiantes, pero nadie sabe en qué terminará el barullo político, y muchos temen que no habrá un happy end" (BARTRA: 2014; p. 16).
}

Os próximos apartados aprofundarão na estruturação do narcotráfico no México e as políticas de combate ao mesmo desde a perspectiva particular do Estado mexicano que foi explicado com anterioridade, fazendo especial ênfase na concepção do Outro institucionalizada na estrutura estatal do país.

\footnotetext{
${ }^{43}$ A diferença de número de votos entre Calderón e López Obrador foi de apenas 233.831 votos de 71.374.373 totais. Fonte: Instituto Nacional Electoral - INE - www.ine.gob.mx
} 
CAPÍTULO II

\section{A guerra contra as drogas}

"O brave new world, that has such people in it"

(William Shakespeare, The Tempest, 1610)

\section{Drogas, proibição e narcotráfico}

Perspectivas sobre as drogas e a proibição do seu uso

O narcotráfico e a questão das drogas são um problema em escala global que tem se desenvolvido com maior potencialidade durante a última década do Século XX e as primeiras décadas do Século XXI, especialmente na região da América Latina e os Estados Unidos, esses últimos os maiores consumidores de drogas no mundo ${ }^{44}$ e representa um negócio altamente lucrativo $^{45}$ inserido diretamente na lógica de acumulação do capital; “[...] en la agenda de

\footnotetext{
44 “Até o final de agosto de 2000, oficialmente, nos Estados Unidos se reconhecia que aproximadamente 15 milhões de pessoas haviam consumido drogas ilegais em 1999 [...] Em fevereiro de 2000, em uma conferência na Cidade do México, Barry McCaffrey afirmava que "nos últimos anos os norte-americanos têm gastado 57 mil milhões de dólares para adquirir alguma droga” (SANTANA: 2012; p. 71).

${ }^{45}$ Por um lado, Alain Labrousse oferece uma tentativa de desmitificação dos colossais ganhos do narcotráfico: "[...] os peritos regionais da Unodc fornecem estimativas (de) [...] 32 bilhões de dólares americanos para os opiáceos afegãos no mercado mundial [...] 10 bilhões para o ópio e a heroína de Mianmar, 10 bilhões para o haxixe marroquino. Para as drogas colombianas e mexicanas, o mercado dos Estados Unidos teria representado 57.3 milhões de dólares em 1995 [...] estas estimativas oferecem uma ordem de grandeza mais próxima do intervalo entre 150 e 200 bilhões de dólares anuais [...]" (LABROUSSE: 2010; p. 56-57). Adalberto SANTANA, por sua vez, oferece outras cifras: "[...] essa indústria gera um comércio mundial que ascende a 500.000 milhões de dólares anuais [...] Outras cifras proporcionadas pelo Observatório Político das Drogas apontam que essa indústria na ordem mundial gera entre 300.000 e 500.000 milhões de dólares, capitais que anualmente são
} 
dichos países aparece de manera destacada la llamada 'guerra contra las drogas,", (SANTANA: 2012, p. 7) impulsionada diretamente desde as políticas dos Estados Unidos da América para com os países latino-americanos.

As redes de operação dos cartéis de tráfico estão articuladas mundialmente desde as escalas mais primordiais de representação geográfica e uso do território. São redes que funcionam eficientemente desde o camponês das montanhas mexicanas até o consumidor em um pub de Londres; “[...] acontece em diversos planos sobrepostos e simultâneos. Está no tiroteio do morro e na fronteira do México com os Estados Unidos; nas selvas sul-americanas e nas montanhas do Kosovo; nas ruas de Madri e nos campos de papoula afegãos" (LABROUSSE: 2010, pág. 13). Porém, é de vital importância diferenciar entre as drogas, o uso das mesmas, a organização do narcotráfico e o combate militarizado às mesmas, assim como a sua posição na agenda como assunto de segurança nacional para os distintos países envolvidos sem obviar as implicações políticas, sociais, econômicas e culturais que giram em torno ao uso das drogas (SANTANA: 2012).

O consumo de drogas no mundo é milenar e pré-data o uso das mesmas como foco do tráfico, isto é, o consumo das drogas é anterior à existência do narcotráfico como organização capitalista transnacional que lucra com o uso das mesmas; a premissa anterior, dentro da sua simplicidade, se contrapõe ao argumento proibicionista da suposta "hipocrisia do consumidor" que fomenta a violência gerada pelo tráfico ao usar drogas.

"El consumo de drogas remite en primera instancia a comprender un hecho histórico, el cual indica que el uso de drogas se ha dado en toda civilización y ha tenido como tradición la búsqueda de la ebriedad, entendida esta en dos sentidos: la festiva y la terapéutica [...] toda gran civilización ha recurrido al consumo de drogas. La sociedad capitalista contemporánea no ha sido ajena a ello" (SANTANA: 2012, p. 29).

Se bem o consumo de drogas é uma atividade que acontece desde os primórdios da humanidade, a demanda das mesmas é uma premissa central no entendimento do poder e complexidade do tráfico de drogas enquadrado dentro da lógica capitalista de consumo: oferta e demanda; é "[...] un rasgo propio del desarrollo capitalista de nuestro tiempo" (SANTANA: 2012, p. 9) e, portanto, o fenômeno do narcotráfico, desde já, é indissociável do funcionamento do Estado e do livre mercado dentro dos territórios em questão. Ao mesmo tempo, é importante diferenciar

'branqueados' pelos seus principais beneficiários: Estados Unidos, Japão, Itália, França e Suíça; estima-se que apenas o 10\% desse total volta aos países produtores" (SANTANA: 2012; p. 166). 
o uso tradicional das drogas que "[...] se distingue del actual 'sistema mundial de la droga', en tanto que forma parte de una serie de prácticas mágico-religiosas tradicional de algunas comunidades étnico-culturales de países de América Latina y de otras regiones del mundo" (SANTANA: 2012, p. 61).

Por um lado, a produção e consumo histórico na região estabelece fortes vínculos com às culturas e o uso do território para, de alguma maneira, ser parte da cosmovisão e do volkgeist dessa população em particular. A produção e consumo tradicional da planta de coca data de 5 mil anos atrás, está “[...] profundamente ligada à identidade dos autóctones dos planaltos andinos $^{46 "}$ e que ainda mantêm o uso tradicional da planta. Além do mais, é possível perceber que para as alteridades invasoras (espanhóis) a planta de coca de fato era útil por estimular o trabalho físico dos índios nos processos de mineração e cuidado das fazendas ou, posteriormente, com o descobrimento da cocaína por parte dos laboratórios farmacêuticos que observaram os benefícios potenciais da droga, levando ao aumento exponencial do seu uso para fins recreativos e médicos (LABROUSSE: 2010, p. 25) e criando, por consequência, um mercado muito lucrativo.

Podemos observar a ausência de conotações negativas à coca, ao seu derivado e ao consumidor da mesma e além dos efeitos negativos que o abuso possa ter no corpo humano, não parece haver ligação com alteridades indesejáveis e, ao invés, é um mercado muito atrativo para a lógica capitalista.

Outro exemplo é o do cânhamo indiano (Cannabis sativa), ou maconha, que possui também uma história milenar de cultivo e consumo. Tendo a sua origem no centro da Ásia, foi apelidada como "o seguidor de homem" pelo fato de ir crescendo atrás das rotas comerciais que ligavam a Europa com a Ásia e, cabe ressaltar, era valorizada não apenas pelos efeitos psicoativos, senão pela sua versatilidade de uso como o aproveitamento das fibras para fazer cordas, por exemplo. A afinidade dos efeitos psicoativos e a sua versatilidade para outros usos favoreceu a sua propagação pelo mundo, chegando ao México na metade do Século XIX, país que viraria o principal produtor da planta no mundo ${ }^{47}$. (LABROUSSE: 2010).

\footnotetext{
${ }^{46}$ Principalmente Colômbia, Peru e Bolívia.

47 “Em 2003, a produção da Cannabis (maconha) no mundo foi avaliada e 42 mil toneladas, que se distribuem da seguinte maneira: América (41\%), África (28\%), Ásia (14\%), Europa (4\%) e Oceania (2\%)(Unodc, 2005. World Drug Report. Nova York, 2005. p. 81-85) [...] Na América, é o México, em que as culturas cobrem dezenas de hectares, que ocupa o primeiro lugar" (LABROUSSE: 2010, p. 49).
} 
Portanto, de onde é que veio a conotação negativa que se tem sobre as drogas e os consumidores? Se bem não é possível e seria inútil negar os efeitos negativos que o abuso das mesmas tem no corpo humano, não é suficiente para satanizar de tal forma o seu uso, sendo que drogas legais tais como álcool e tabaco são mais prejudiciais para a saúde. Por outro lado, o consumidor parece carregar consigo estigmas que o fazem virar um Outro-indesejável. Não é necessário profundar no imaginário coletivo do "maconheiro comunista" ou da "crackolândia"; porém, esses estigmas parecem ser seletivos já que, por exemplo, a mesma imagem deplorável não aparece se falarmos do alto executivo de Nova York que ocasionalmente consome cocaína para ser funcional no dia a dia ou do jovem que consome êxtase na boate de Estocolmo no meio da high life europeia. A criação e alocação de esses estigmas de alteridade indesejável provase, de novo, não ser inocente e, ao invés, esses estigmas parecem ser criados e assignados de maneira intencional. O estigma não vem da droga per se, senão que é o binômio do tipo de droga e o tipo de pessoa que a estiver usando o que vai determinar se é desejável ou indesejável.

Este paralelismo com o pensamento de Bourdieu (2002) resulta vital para entender a discordância e a origem dos estigmas de certos grupos sociais em contraste com a aceitação de outros grupos involucrados na mesma atividade (o consumo de drogas) tanto por parte do Estado como dos próprios indivíduos involucrados, neste caso, na guerra contra as drogas. Além do mais, permite visualizar um problema mais grave ainda que é a utilização de essa mesma lógica de produção de alteridades indesejáveis para outros aspectos da vida dos indivíduos como são a raça, o pensamento político, a origem étnica, a orientação sexual, a posição no aparelho de produção e consumo ou mesmo atividades corriqueiras do dia a dia para criar uma rede de inter-relações entre as características escolhidas de forma que pertencer a uma categoria significaria, de uma ou outra forma, pertencer as outras (i.e., o maconheiro comunista e pobre). A perversidade da criação arbitraria de essa rede de estigmas é que seria feita, segundo o pensamento de Bourdieu, desde a hegemonia em questão e pode legitimar o extermínio generalizado de grupos inteiros tendo como alvo apenas um dos estigmas criados (como estar relacionado ao mundo das drogas). Isto se relaciona diretamente com a guerra contra as drogas e os alvos a serem exterminados.

Do anterior decorre uma questão central: a percepção negativa de certas drogas com certos usuários (i.e., criminalização) está inscrita em letras de ouro na essência da guerra contra as drogas. Não pode haver combate armado contra um inimigo abstrato, pode sim declarar a guerra contra entes abstratos (a guerra contra o terror de George Walker Bush como máximo expoente), porém, é necessário sair do abstrato e produzir um inimigo físico que as bombas e 
as balas possam atingir e, é claro, esse alvo é criado mediante a seleção de características negativas e a sua homologação com práticas, culturas, raças, etc.

No caso da guerra contra as drogas, podemos traçar a origem do combate militarizado como questão de segurança nacional até a presidência de Richard Nixon (1969-1974) e o estabelecimento da Comissão Shafer para fazer uma avaliação sobre a situação das drogas nos Estados Unidos. A conclusão da comissão foi que "[...] no había conexión entre el cannabis y otras formas de criminalidad. Asimismo, determino que el alcohol era más peligroso que la marihuana y que el uso personal de esta última debería ser descriminalizado lo antes posible" (LINTON: 2015, p. 69-70). A conclusão da comissão foi rapidamente rejeitada pela administração Nixon que agiu de maneira totalmente contrária ao declarar as drogas como "[...] inimigas dos Estados Unidos por ameaçarem a saúde e a ordem política internas, e a estabilidade de países e regiões do globo" (LABROUSSE: 2010, p. 9).

A declaração de guerra do presidente conservador Nixon começou o complexo e sanguinário processo da Guerra contra as Drogas no mundo inteiro, especialmente na região latinoamericana que é o foco da presente pesquisa. Porém, ao pensar na postura altamente conservadora de Nixon e os motivos e os fins que o levaram a declarar a guerra contra as drogas temos de pensar na face tangível e humana que viraria o alvo: o Outro exterminável. A década de 60 e 70 se caracterizou pelo surgimento de movimentos de contracultura encarnados nos hippies ou nas juventudes negras (como os Black Panthers) que tinham uma posição totalmente oposta ao conservadorismo da administração Nixon no caso (emblemática é a resistência contra a Guerra do Vietnã) e é sabido que esses grupos contracultura gostavam de fumar um por motivos diversos, desde a libertação da mente com fins artísticos, o simples fato de desfrutar do estado de consciência alterado ou o como forma de evasão da realidade em épocas da guerra do Vietnã, do recrutamento compulsório e da morte de milhares de jovens e, desta forma, o consumo foi integrado às suas práticas ritualísticas de autoafirmação diante do Outro. Não seria provável que as motivações de um ultraconservador católico e defensor inalcançável dos "bons costumes americanos" fossem combater a esses grupos mediante a criminalização de uma prática que os definia diante do Outro-hegemônico? Situação que é exposta pela revista Harper's na qual John Ehrlichman, membro do governo de Nixon, afirma que a guerra contra as drogas foi começada para "conter a dois inimigos: a esquerda antiguerra e à gente negra" 48

\footnotetext{
48 "Sabíamos que no podríamos hacer ilegal protestar contra la guerra o ser negro, pero al hacer que el público asociara a los hippies con la mariguana y a los negros con la heroína, y al criminalizar ambas cosas severamente, podríamos desbaratar comunidades [...] podíamos arrestar a sus líderes, catear sus hogares, terminar con sus juntas y vilipendiarlos noche tras noche en los noticiarios nocturnos. ¿Sabíamos que mentíamos sobre las drogas?
} 
em um claro exemplo de fabricação intencional do Outro-exterminável com fins políticos e raciais.

“[...]'trata de imponerse un axioma en el que cualquier elección subjetiva es una enfermedad o un delito, cuando no ambas $\operatorname{cosas}^{49}$. Al prohibirse el libre consumo de determinadas drogas surge de manera impulsiva el comercio clandestino, es decir, lo que hoy se conoce como tráfico ilícito de drogas" (SANTANA: 2012, p. 30-31).

A guerra seria travada nos países produtores com a formação de grupos de elite antidrogas dentro das próprias forças armadas latino-americanas e faria mais complexo o conflito ao articular-se com a Guerra Fria e os grupos guerrilheiros da região (FARC, Sendero Luminoso) para criar o conceito de narcoterrorismo como associação entre grupos dissidentes/terroristas e o seu financiamento mediante o tráfico de estupefacientes. O conceito de narcoterrorismo se afiançaria como eixo fundacional da militarização após os ataques do 11 de setembro ao World Trade Center (LABROUSSE: 2010).

Antes de entrar na cronologia exposta anteriormente sobre a forma na qual se criaram e executaram as distintas políticas de combate armado ao narcotráfico e a sua posterior vinculação com os conceitos de terrorismo, guerrilha e alteridade dissidente, é necessário entender e analisar ao fenômeno do narcotráfico na sua acepção geopolítica, seja desde a sua estruturação na escala local do território até a nacional e internacional, fazendo ênfase na sua interação direta com o Estado.

\section{Geopolítica do tráfico}

O narcotráfico precisa controlar territórios, seja para o cultivo da droga ou para o trânsito da mesma e, portanto, se estabelece uma luta pelo controle de um ou vários territórios que tecnicamente estariam sob o controle do Estado em questão. Trata-se do uso do território com uma lógica geopolítica: "conflitos de poder para o controle de territórios, das riquezas que estes possuem e dos homens que as produzem” (LABROUSSE: 2010, p. 15). Em consequência, o narcotráfico se organiza como uma indústria que funciona em diversas escalas geográficas,

Claro que sí." - "Guerra contra las drogas” de Nixon en los 70's, plan para controlar a hippies y negros Redacción Proceso, publicado em 24 de março de 2016, disponível em: http://www.proceso.com.mx/434621/guerra-contra-las-drogas-nixon-en-los-70s-plan-controlar-a-hippies-anegros - acessado em abril de 2016.

${ }^{49}$ Antonio Escohotado, Historia de las drogas, vol.3, p. 349. 
sociais e de produção, por exemplo: desde o nível internacional onde o maior padrão de consumo de drogas se concentra nos países desenvolvidos, provoca a aparição de uma nova ordem de acumulação de capital estruturado sob uma lógica de produtor - exportador consumidor final com uma estruturação interescalar, ou seja, essa estrutura pode ser observada em distintos níveis de escala geográfica, seja o consumo local, nacional ou internacional, seguindo nesse último nível o padrão da periferia produtora e o centro consumidor (SANTANA: 2012).

Essa articulação por escalas territoriais de funcionamento é proposta por Antônio Gama (1998) como forma de observar e analisar fenômenos e a relação que se mantem com a "forma geométrica" que é o território. A divisão por escalas está, por consequência, ligada às formas de exercício de poder sobre os atores e instituições que agem na espacialidade em questão. Em seguida, o exercício do poder compõe-se de cinco pilares que lhe dotam de estrutura, justificativa, razão, institucionalidade e atores/agentes. Portanto, seguindo a lógica anterior, o narcotráfico funciona em quatro escalas principais: 1) local; 2) regional; 3) nacional; e 4) mundial; para funcionar em cada uma delas precisa dos cinco pilares ${ }^{50}$ que serão variáveis de escala a escala: a) um mecanismo de estruturação de poder; b) formas de direito; c) formas de racionalidade; d) instituições privilegiadas e e) agentes/atores.

Portanto, fazendo o exercício ${ }^{51}$ na escala local e na escala nacional para ver a articulação do narcotráfico com o cidadão comum e com o Estado podemos observar o seguinte:

1.- Na escala LOCAL, tendo como território um campo de cultivo, as relações de poder entre traficante e camponês se estruturam a partir da violência e da coerção - se legalizam através do uso e do monopólio da violência - a razão e finalidade é manter o monopólio da produção da droga em questão - a dominação violenta institui a relação de poder - os atores/agentes da relação de poder no território são os comandos locais de traficantes e os camponeses.

2.- Na escala NACIONAL, tendo como território ao Estado-nação, as relações de poder entre os cartéis e o Estado se estruturam a partir da corrupção e infiltração da estrutura de administração estatal - se legalizam através da desconexão do Estado para com a população e da dominação e bloqueio às instituições de acesso à justiça - a razão e finalidade é criar uma

\footnotetext{
${ }^{50}$ a) Através do que se estrutura a relação de poder entre atores; b) O regulamento que faz possível a relação de poder-dominação; c) O motivo ou razão que dá lugar ao estabelecimento de relações de poder; d) Através de que contrato ou instituição social se estabelecem as relações de poder; e) Os atores/agentes participantes das relações de poder.

${ }^{51}$ Ver anexo 3 para uma esquematização completa - Esquema construído a partir da teoria das escalas territoriais proposta por Antônio GAMA (1998).
} 
simbiose com o Estado para ambos coexistirem - as relações de poder instituem o NarcoEstado - os atores/agentes da relação de poder são os capos/ cartéis e os funcionários públicos/Estado.

O anterior é observável, desde a perspectiva de escala global, ao apreciar que as parcelas agrarias das nações latino-americanas, dentro do aparelho econômico local tanto internacional, conseguiram trilhar seu caminho à economia globalizada de livre mercado através do cultivo de mercadorias ilegais ${ }^{52}$. Embora a articulação com a economia global através do monopólio violento do narcotráfico, podemos ver como essas parcelas populacionais consideradas como Outro indesejável e explorável rompem com a sua assimetria de articulação econômica e se aproveitam do mercado que a proibição estatal das drogas criou. Por outro lado, o narcotraficante, antigo camponês pobre e agora monopolizador de amplas redes de circulação de mercadoria e capital, se separa desse Outro explorável e vira Outro hegemônico que continuará explorando aos camponeses que estão ao seu serviço.

\footnotetext{
"Frente a estas condiciones de vida, a esos segmentos del campesinado mexicano no les queda de otra opción que cultivar amapola y marihuana en las zonas serranas y selváticas, cultivos que les brindan la posibilidad de allegarse algunos recursos para sobrevivir en su precaria situación de marginación y pobreza. Por ejemplo, en abril de 2003, se denunciaba que entre la sierra de los estados de Durango y Zacatecas los plantíos de marihuana y amapola se esparcían en 30000 hectáreas de bosques ricos en maderas. Ésta es una zona poblada por indígenas tepehuanos y ejidatarios zacatecanos que viven en la extrema pobreza y que son presionados por los narcotraficantes para trabajar como una productiva mano de obra" (SANTANA: 2010, p. 183).
}

Por sua vez, o narcotráfico, como fenômeno de escala mundial articulado em distintas escalas sociais, tem se incorporado com eficiência aos mercados de produção tanto globais como locais. O perigo inerente dessa versatilidade e adaptabilidade do tráfico de drogas é particularmente alto na escala local já que é nesse nível no qual os grupos sociais periféricos e vulneráveis ficam à mercê do narcopoder. A mesma fragmentação do narcotráfico em escalas de organização desde o local até o transnacional não apenas o fazem mais eficiente, senão que permite a sua infiltração em setores locais e vulneráveis da sociedade; setores afastados, ignorados ou as vezes indesejáveis desde olhar das políticas de segurança do Estado. O Outro indesejável encontrou no narcotráfico outro polo de exploração e extermínio.

\footnotetext{
52 "Como é o caso de não menos de 300.000 camponeses nos Andes sul-americanos que participam como provedores de matéria prima: coca (200.000 hectares), papoula (1.500 hectares) e maconha (não menos de 1.000 hectares), que provêm para os mercados regionais e internacionais" (SOBERÓN: 2010).
} 
Desde a perspectiva do narcotráfico como estrutura local, nacional e internacional, Norberto Emmerich (2015) o define como uma organização puramente capitalista e vinculada ao Estado essencialmente, isto é, ambos nasceram como organizações “criminosas”. Já a diferença radica no êxito do Estado ao legalizar-se paulatinamente mediante o uso da força e o disciplinamento para "naturalizar lo inaudito" (EMMERICH: 2015, pág. 19), ou seja, o monopólio "legítimo" da violência. O narcotráfico se apresenta, segundo Emmerich, como concorrência do Estado ainda na sua fase inicial, porém, sem vergonha, sem ataduras e sem hipocrisias. O narcotráfico é a essência do Estado capitalista sem a necessidade de se legitimar nem de se naturalizar para aparentar ser uma organização benfeitora, é "una ética capitalista de producción social y acumulación individual, aunque con menor desigualdad de ingresos" (EMMERICH: 2015, pág. 19).

Posteriormente, Emmerich (2015, pág. 20) propõe uma série de premissas para entender o fenômeno do narcotráfico e a sua intrínseca proximidade para com o Estado: a) Somente pode ser compreendido entendendo a formação histórica do Estado; b) é um processo, não uma acumulação de fatos independentes; c) é uma atividade invisível que se visibiliza mediante os crimes predatórios ou a luta pelo território; d) tem procedimentos previsíveis, estruturados, repetitivos e burocráticos; e) coativo, monopólico, territorial, estável e tem comportamento político com fins estatais; f) narcotráfico e drogas são vinculados, mas distintos; g) a vinculação do narcotráfico é mais forte com o Estado do que com as drogas; h) definir ao narcotráfico como tráfico de drogas é etimologicamente correto, ontologicamente errado e politicamente inútil, o narcotráfico conquista territórios para produzir e vender, sem esse monopólio violento pode haver comercio, mas não narcotráfico; i) o objetivo do narcotráfico de obter lucro é falso cientificamente, o narcotráfico gera capital, não dinheiro; é uma indústria, não um negócio; é uma relação social de dominação, não apenas uma atividade ilegal.

Finalmente, estabelece três pontos principais: 1) O narcotráfico é o máximo exponente da ética capitalista; 2) quando falamos de narcotráfico não falamos de drogas, senão do Estado; 3) quando falamos de narcotráfico não falamos de delito, senão de política (EMMERICH: 2015, pág. 20).

Uma vez estabelecida a ordem de funcionamento interescalar do narcotráfico no aspecto geopolítico e a sua direta e variada vinculação com o Estado, é pertinente analisar as políticas de segurança direcionadas ao combate militarizado contra as organizações do tráfico de drogas e a evolução do termo narcoterrorismo desde a perspectiva da integração continental emanada 
da hegemonia dos Estados Unidos na região através de planos de ação emblemáticos da guerra contra as drogas como o Plan Colombia e especialmente a Iniciativa Mérida (ou Plan México).

\section{As políticas da hegemonia}

Integração continental, hegemonia e políticas de segurança

A hegemonia dos Estados Unidos no continente e no mundo tem sido construída desde os seus primórdios como nação independente, passando pelo fortalecimento interior e regional do Século XIX e a confirmação do seu status como potência mundial após o fim da Segunda Guerra Mundial. O esquema de expansão estadunidense foi seguindo precisamente esse padrão: estabilidade interior para pensar no próximo-exterior e finalmente atingir a dominação mundial. Esse processo não poderia ter acontecido sem a aplicação de preceitos de dominação coercitiva e de segurança do território funcionando em co-dependência no chamado binômio de integração-segurança: "[...] una relación estrecha entre políticas de integración económica con acciones y determinaciones de manutención de la seguridad hemisférica, o continental" (NOVION: 2009, p. 61).

O conceito de hegemonia e do Outro que a exerce, aplicado em uma escala continental, deixa entrever as tramas de construção da alteridade na região dominada pelos Estados Unidos. A construção hegemônica da nação estadunidense, como foi mencionado, precisou em primeira instância se definir e auto afirmar internamente como o povo escolhido para dominar o continente (e posteriormente o mundo) mediante a criação de mitos de origem como o Destino Manifesto e a Doutrina Monroe para, paralelamente, consolidar o território ou o espaço vital e estabelecer usos e costumes sobre ele que, em retorno, ajudariam à criação e manutenção do volkgeist estadunidense.

Em um primeiro momento interno, o avanço territorial ou a marcha para o oeste mediante a compra da Luisiana reafirmava e legitimava ao Destino Manifesto, criava alteridades indesejáveis para a autoafirmação do povo estadunidense (como os nativos americanos) e ampliava o espaço vital. Posteriormente, a afirmação para o exterior e a criação de um Outro- 
indesejável estrangeiro e o estabelecimento como potência regional veio com vitória na Guerra México-Estadunidense e a conquista da metade do território mexicano. O caminho para o domínio continental estava aberto.

\begin{abstract}
"El proceso de consolidación de un poder hegemónico mundial, está intima e históricamente ligado al controle previo de un espacio territorial, de un 'espacio vital' capaz de ofrecer las condiciones concretas para su avance. Estas condiciones como producción y abastecimiento, circulación de mercancías, extracción de recursos naturales y energéticos, generación de empleos, absorción del excedente poblacional a contingentes militares, cooptación o aniquilación de posibles insurgencias se perfilan como algunos ejemplos"
\end{abstract}

(NOVION: 2009, p. 63)

De esta maneira, as políticas de intervenção dos Estados Unidos para a América Latina se fundamentariam no binômio de integração/segurança que passaria por momentos diferentes ao decorrer da história respondendo ao contexto particular do momento ${ }^{53}$ seguindo a expansão hegemônica dos Estados Unidos desde a sua origem e organização interna como nação e o projeto a ser seguido, a vitória na guerra contra o México e as aquisições territoriais para estabelecer-se como hegemonia regional e a posterior expansão no continente através da dominação estratégica do Caribe e da América Central para adentrar-se no sul do continente durante a época da proliferação das ditaduras sul-americanas (NOVION: 2009). Com o fim da Guerra Fria e a aparente vitória do sistema capitalista por encima da União de Repúblicas Socialistas Soviéticas - URSS, a agenda do Estados Unidos se enquadraria na Dominação de Espectro Completo - DEC que visava estabelecer e afiançar a hegemonia dos Estados Unidos na escala global levando à consideração a pulverização das "ameaças" após a queda da URSS e a consequente ampliação dos acontecimentos ou alteridades que seriam considerados assunto de segurança nacional (NOVION: 2009). Portanto, a DEC vai além de uma visão militarizada

\footnotetext{
53 Jacques de NOVION (2009, p. 114-115) identifica distintos momentos na evolução e fortalecimento da hegemonia estadunidense mediante a aplicação de distintos binômios de integração econômica e segurança local e continental: 1) Organização interna e construção da identidade nacional - garantir a não recolonização do território; 2) Expansão territorial por vias da negociação (com a França) ou pela via da guerra (contra o México) e a doutrina do Pan-americanismo (1889) - Doutrina Monroe, ou a defesa conjunta do continente contra as potencias europeias; 3) Pan-americanismo II - Diplomacia do dólar (cooperação) ou política do garrote (coerção), expansão hegemônica ao Caribe e América Central; 4) Interamericanismo e Boa Vizinhança - Política de contra-insurgência; 5) Interamericanismo II (criação da OEA), multilateralidade desde a negociação coercitiva bilateral Anticomunismo, Operação Condor e a era dos golpes patrocinados pela CIA na América do Sul, expansão hegemônica para a totalidade do continente, 6) Subperíodo de caráter multilateral, criação de áreas de livre comércio (ALCA) - Combate ao narcotráfico, políticas ambientais e contenção da imigração latino-americana; 7) Subperíodo de caráter bilateral, tratados de livre comércio (TLCAN), Plan Bolivia e Plan Colombia (narcotráfico), Plan Puebla-Panamá (meio ambiente), Iniciativa Mérida (narcoterrorismo) - Dominação de espectro completo, combate ao terrorismo após o 11/9, doutrina anti-narcoterrorismo.
} 
de uso de forças regulares no campo de batalha para a conquista e ocupação de territórios (visão que já tinha começado a mudar na guerra por satélites entre os Estados Unidos e a União Soviética $^{54}$ ao afastar o combate armado o mais longe possível dos centros dos sistemas) ou da visão de um grande inimigo muito bem definido com pequenos aliados/vassalos. A nova visão do mundo contempla a existência de diversas ameaças encarnadas em pequenos grupos ou indivíduos e não na existência de um Estado-nação essencialmente rival (NOVION: 2009, p. 136).

Portanto, a doutrina hegemônica dos Estados Unidos no seu momento de dominação mundial mediante a DEC e os conceitos governantes das políticas de integração e segurança emanadas de dita doutrina estão fundadas nos seguintes preceitos: a) Aproximação política às elites e governos locais; b) política econômica para fortalecer as relações de produção e exploração dos recursos naturais do território em questão; c) conquista das mentes ou domínio psicológico das populações dos países alvo; e d) ação militar contra insurgente para o controle e pacificação do território (NOVION: 2009).

A guerra contra as drogas será articulada estrategicamente a partir da DEC seguindo a própria evolução da hegemonia estadunidense. Como foi mencionado, o combate às drogas foi inaugurado oficialmente durante a presidência de Richard Nixon nos Estados Unidos após desestimar os resultados da Comissão Shafer e declarar as drogas como um perigo para a segurança nacional dos Estados Unidos. A guerra, é claro, não aconteceria em solo estadunidense, senão que seria travada nos países produtores da América Latina, principalmente na Colômbia e posteriormente no México mediante a efetivação de planos de ação ratificados bilateralmente, mas propostos desde a unilateralidade (NOVION: 2009) que visariam financiar às forças armadas dos países alvo para, no papel, fazer frente aos cartéis da droga.

O conceito de "guerra contra as drogas" sofreu mutações importantíssimas desde a sua inauguração na administração Nixon. A queda da União Soviética teve um impacto profundo na desideologização e esquematização do combate às drogas. Por sua vez, a queda do comunismo “[...] deixou aos Estados Unidos órfãos de uma ameaça que possibilite unificar o país e mobilizar suas potencialidades nesta luta” (MESSARI: 2004, p. 137) e que ajudasse a reafirmar a identidade estadunidense diante de um Outro-ameaçador; diante da queda da ameaça do comunismo representado pela URSS, o novo inimigo favorito dos Estados Unidos

\footnotetext{
${ }^{54}$ Como a Guerra da Coreia (1950-1953), a Guerra do Vietnã (1955-1975) ou a Invasão soviética do Afeganistão (1979-1989), etc.
} 
se encarnaria no narcotráfico no final da década de 1980 até o ano de 2001 quando o terrorismo entraria na equação.

De esta forma, os grupos armados dissidentes da América Latina começaram a ser identificados como grupos guerrilheiros que teriam abandonado qualquer ideologia que tivessem reivindicado com anterioridade para usufruir do tráfico ilegal de drogas nos respectivos países. Se bem, as ganâncias produto do tráfico de estupefacientes são efetivamente utilizados por grupos guerrilheiros para o autofinanciamento mediante uma troca de serviço que implica a proteção dos camponeses contra outros grupos que pretendam monopolizar a produção e comercio da droga e das mesmas forças do Estado. Os grupos guerrilheiros cobram impostos pelo cultivo e trânsito da droga nos territórios por eles controlados ou são eles mesmos que se ocupam do transporte da mercadoria. Porém, Alain Labrousse (2010) chama a atenção dos perigos do financiamento de um grupo dissidente com o lucro econômico do tráfico de drogas já que facilita a criminalização e de-ideologização do mesmo, fazendo-o alvo legitimamente exterminável ao carecer de estatutos ideológicos que possam ser matéria de discussão nacional. Ao mesmo tempo, os mesmos ganhos exponenciais do tráfico de drogas pode corromper à essência da dissidência criando uma guerrilha desvirtuada, isto é, quando a droga vira uma questão central do conflito seja pelo controle dos recursos econômicos diretos do tráfico ou pelo controle de zonas e rotas de cultivo e trânsito. Além do mais, o confronto direto contra as Forças Armadas do Estado tendo como foco o controle de recursos ou de rotas e campos de cultivo acaba por legitimar a criminalização e de-ideologização do conflito, fazendo-o virar um conflito de drogas no qual não há discussão nenhuma, apenas o extermínio dos agora traficantes (LABROUSSE: 2010).

É assim que existe de fato um motivo para que a de-ideologização de um conflito seja tão atraente e eficiente para o Estado no combate à dissidência interna, desde uma perspectiva nacional-regional. E tão atraente para os Estados Unidos como forma de criação de alteridades indesejáveis que reafirmem o seu motivo de existir como o Policial do Mundo e facilitar a entrada e dominação da região mediante o financiamento às forças armadas no combate à dissidência interna e possíveis focos de conflito dos países alvo. Não se trata de uma intervenção direta nem de um ataque dirigido contra um grupo ideologicamente divergente, senão que é o extermínio de grupos de tráfico de drogas, e, portanto, se autolegitima.

As políticas de segurança projetadas com esse fim são criações e proposições elaboradas pelos Estados Unidos para contemplar a ideia de erradicação sem negociação diante da dissidência política dedicada ao tráfico de drogas, o qual derivou na militarização sem alternativas do 
conflito na Colômbia e posteriormente no México (MESSARI, 2004). Na América Latina, a homologação da dissidência ideológica armada com o tráfico de estupefacientes " [...] tornou viável a ampliação da repressão militarizada adotada por muitos governos desde a década de 1980” (LABROUSSE: 2010, p. 11) e a concretizou na celebração do Plan Colombia que se focava no combate militarizado contra o tráfico de drogas, as FARC, o Ejército de Liberación Nacional - ELN e outras forças guerrilheiras. Posteriormente seria redimensionado e implementado no México sob o nome de Iniciativa Mérida.

Antes de aprofundar nos planos efetivados tanto na Colômbia como no México, é necessário observar e apreciar como a reelaboração do conceito de Outro-indesejável em um nível mundial está se desenvolvendo até este momento e como é que emanado desde a hegemonia permeará nos países alvo das políticas de integração-segurança implementadas. A começo da guerra contra as drogas como uma cruzada pelos bons costumes, estabilidade e saúde dos Estados Unidos já teria criado em um primeiro momento uma noção de alteridade indesejável dirigida contra grupos raciais e políticos específicos (como foi mencionado o caso dos negros, hippies, da esquerda, setores progressistas e liberais antiguerra da administração Nixon). Essa inércia se propagaria na esfera de influência hegemônica dos Estados Unidos na América Latina como forma de combate e contenção de grupos dissidentes, armados ou pacíficos, como uma forma de controle cultural e controle das mentes, formas das quais Jacques de Novion (2009) fazia referência na chamada DEC.

A criação de alteridades indesejáveis responde à agenda de hegemonia dos Estados Unidos após a vitória sobre o comunismo soviético decorrente da necessidade de homogeneizar ao mundo que foi polarizado pela Guerra Fria e criar "[...] um mundo mais favorável aos interesses Norte Americanos" (MESSARI: 2004, p. 140). Entre mais parecidas sejam as condições regionais e locais com o pensamento econômico e cultural estadunidense, mais fácil será a dominação completa dos territórios sem necessidade de recorrer a intervenções militares ou golpes de Estado. Portanto, a diversidade deveria ser sacrificada mediante a homologação da diferença com características indesejáveis particulares da evolução histórica das alteridades em cada país ou região em um primeiro momento com ideologias afins do comunismo internacional durante a Guerra Fria e posteriormente com o consumo de estupefacientes, a de-ideologização dos conflitos ideológicos e a entrada do terrorismo como ferramenta de criminalização da dissidência e legitimação do extermínio da mesma. O anterior lembrando que as políticas de integração e segurança emanam de uma posição hegemônica de articulação assimétrica dos dominados para com o dominador que estabelece e define o que é um Outro-indesejável e, 
portanto, é uma imposição sem negociação, ratificada bilateralmente em aras de preservar a segurança dos cidadãos e assegurar a integração e desenvolvimento econômico de uma nação, porém proposta desde a unilateralidade que pretende homogeneizar às sociedades mediante o extermínio legitimado do Outro.

\footnotetext{
"A diversidade era sacrificada porque a homogeneidade do mundo era tida como mais segura para os EUA. Por isso, a diferença era tida como negativa e, portanto, perigosa para os interesses dos EUA. Neste contexto, ser um amigo/aliado dos EUA tem um preço definido, i.e., emular e reproduzir o modelo norte americano, econômica e politicamente. Não se trata, portanto, por parte do EUA de fazer concessões mutuas para chegar a um compromisso" (MESSARI: 2004, p. 140).
}

O ataque contra o World Trade Center em setembro de 2001 radicalizou a postura estadunidense em questões de segurança nacional tendo três consequências principais: 1) a redefinição do conceito de segurança mesmo; 2) a transformação do terrorismo como o inimigo principal dos Estados Unidos; e 3) a reelaboração da estratégia de defesa dos estadunidenses (MESSARI: 2004, p. 132). Em paralelo, a faixa fronteiriça entre o México e os Estados Unidos vê aumentada a vigilância por parte do recém-criado Department of Homeland Security, criando uma barreira que dificultaria a entrada de drogas no território e, por consequência, criando um mercado de venda e consumo no México o qual fortaleceria aos já poderosos cartéis mexicanos.

Do anterior decorre uma posição a ser defendida na presente pesquisa: o ataque terrorista do 11 de setembro reconfigurou a estratégia de defesa nacional dos EUA fazendo-a voltar ao passado da Guerra Fria e da Segunda Guerra Mundial em um estado de guerra total no qual a única opção é a vitória total e a rendição incondicional do inimigo. As alternativas políticas de negociação são reduzidas ao papel de um simples apoio para enfraquecer ao inimigo financeira e diplomaticamente e não cumprem um papel de resolução do conflito (MESSARI: 2004). Como parte da radicalização das políticas de segurança, os conceitos de narcotráfico e terrorismo, vinculados entre si desde o começo da guerra contra as drogas, são incorporados totalmente em um só: Narcoterrorismo; simplificando e fazendo mais eficientes as formas de intervenção contra os inimigos dos Estados Unidos. É um conceito redutor que facilita a legitimação do extermínio da dissidência ou dos " [...] mais diferentes agentes não estatais dedicados a causas políticas discrepantes do modelo democrático liberal elou atividades ilícitas" (LABROUSSE: 2010, p. 11) fazendo que grupos como as FARC ou Sendero Luminoso sejam considerados dentro da mesma categoria de Al-Qaeda ou do Estado Islâmico do Iraque e Síria - ISIS e, ainda mais perigoso, deixando aberta a porta para que grupos ou 
indivíduos dissidentes sejam categorizados e identificados por características de um Outro indesejável e sejam sujeitos às políticas de segurança projetadas para combater aos grupos anteriormente mencionados.

O caso do Plan Colombia como precedente da Iniciativa Mérida e o começo da guerra contra as drogas no México chama a atenção pela mudança que trouxe referente à aproximação ao conflito com as Fuerzas Armadas Revolucionarias de Colombia - Ejército del Pueblo FARC-EP. A negociação original do Plan Colombia em 1998 entre os então presidentes Andrés Pastrana e Bill Clinton estipulava o combate às drogas, diferenciando-o do combate às guerrilhas internas, principalmente às FARC, embora já existisse a dependência do financiamento no trânsito ilícito de drogas; a intenção era também o combate à pobreza e as poucas oportunidades de desenvolvimento para o país, situações que Pastrana considerava de fato a causa e origem da insurgência das FARC (EMMERICH: 2015). Isto em um primeiro momento, já que pouco tempo depois, Pastrana recuaria e declararia a "narcotização" do conflito colombiano ao argumentar que a única forma do povo colombiano encontrar a paz era mediante a erradicação da cocaína (LINTON: 2015).

As operações, portanto, se centraram no combate armado e a erradicação tanto das FARC como da produção de cocaína deixando ver que era impensável tratar ao conflito da guerrilha como uma questão de política nacional sujeita a discussão pública. O conflito é de-ideologizado e reduzido ao papel de simples traficantes de cocaína e, portanto, extermináveis. De essa maneira, o governo colombiano, encabeçado Álvaro Uribe, lucraria fantasticamente com os recursos do Plan Colombia provenientes dos Estados Unidos ${ }^{55} \mathrm{e}$, ao mesmo tempo, se veriam legitimados no poder por combater ao tráfico de drogas e eliminariam à dissidência armada existente no território.

Porém, a lógica de Uribe não considerava em momento nenhum o extermínio da galinha dos ovos de ouro que o narcotráfico encarna; ao invés, gira em torno do que Norberto EMMERICH explica como a "[...] acumulación económica capitalista en relación al crimen en general y al narcotráfico en particular" (2015, p. 121) e, portanto, as ações deviam ser dirigidas à integração e incorporação do narcotráfico ao Estado mediante "[...] el mecanismo de

\footnotetext{
55 “Quase o $80 \%$ dos fundos de contra insurgência, todos os quais preveniam dos Estados Unidos (que há gastado quase $\$ 7$ mil milhões de dólares na Colômbia desde 2002), dirigiram-se aos militares e policiais colombianos, enquanto que a ajuda ao desenvolvimento proveniente de outros países, nunca se materializou por completo. As conversas de paz fracassaram, os militares ingressaram na zona desmilitarizada e o conflito escalou. As operações de segurança se centraram nas zonas sul e leste da Colômbia, que se consideravam bastiões das FARC e, não casualmente, duas das principais regiões produtoras de coca na Colômbia" (EMMERICH: 2015, p. 117).
} 
cooptación de oligarquías competitivas. Se creó el escenario para que un proceso de acumulación capitalista primitivo, como es típicamente el narcotráfico, se convierta en una acumulación capitalista normal" (p. 121). De esta forma, o combate ao tráfico de drogas do Plan Colombia vira uma autêntica falácia e um pretexto para combater à dissidência das FARC com a legitimidade que o conceito de NarcoTerrorismo outorga e as vantagens de fazê-lo com recursos provenientes dos Estados Unidos e disfarçando o extermínio da alteridade sob a política dos "falsos positivos" $"$.

\footnotetext{
“Álvaro Uribe fue un presidente que decidió pactar con el narcotráfico como una forma racional de ingresar al PIB una rama productiva que estaba operando en forma ilegal. Bajo una racionalidad netamente capitalista, utilizo el ejercicio del poder para implementar un cambio radical en la economía política de Colombia" (EMMERICH: 2015, p. 122)
}

Os preceitos e a lógica atrás da implementação do Plan Colombia seriam posteriormente adequados para serem aplicados no México sob o nome de Iniciativa Mérida durante a administração de Felipe Calderón e seriam continuados no governo de Enrique Peña Nieto no marco do retorno do PRI ao poder.

\section{Da Iniciativa Mérida ao NarcoEstado}

\section{Narcotráfico mexicano}

Os cartéis mexicanos têm um papel muito importante dentro do esquema de tráfico internacional de drogas relacionado com as rotas de trânsito. A localização do México entre os Estados Unidos e o restante do continente fazem que o território mexicano vire a única rota terrestre de trânsito de drogas. Ao mesmo tempo, a própria extensão da faixa fronteiriça entre México e Estados Unidos facilita a introdução de drogas em território estadunidense devido à dificuldade de manter vigilância constante nos 3.000 quilômetros de extensão.

\footnotetext{
${ }^{56}$ O então Ministro da Defesa, Juan Manuel Santos, mascarou a morte de 3.500 pessoas como se fossem guerrilheiros abatidos; uma forma de criminalização e legitimação do extermínio da alteridade que será analisada no caso mexicano nos próximos apartados (EMMERICH: 2015).
} 
A distribuição geográfica dos cartéis dentro do território encontra-se em direta relação com o tipo de tráfico que o país exerce, o qual por sua vez depende da localização geográfica do território dentro do esquema global. Cada país terá características territoriais diferentes que determinarão as necessidades de funcionamento de cada cartel em questões de relação com o Estado, as operações funcionais de produção, consumo e trânsito e os territórios que precisariam ser dominados; todo o anterior reflete no poder que o cartel exercerá, tanto na faceta de infiltração do Estado como no aspecto beligerante. Norberto Emmerich (2015) faz uma rápida exemplificação do anterior usando os exemplos da Colômbia e do México ${ }^{57}$ :

a) Colômbia: Possui uma localização bi oceânica que favorece a exportação da droga por via marítima para os dois litorais mexicanos e uma fragmentação territorial interna produto da topografia e a distribuição da selva; isto facilita o surgimento de caciques locais e dificulta a penetração do Estado nacional, além do mais, fomenta o surgimento do narcopoder localizado e limitado pela própria fragmentação territorial que limita ao Estado. Surgem cartéis de cidade ou zona (Cartel de Medellín, de Cali, del Valle, etc.).

b) México: Como foi mencionado, a enorme faixa fronteiriça compartilhada com os Estados Unidos é variada: possui duas rotas de entrada pelos litorais atlântico e pacífico, planaltos desérticos e duas rotas de entrada montanhosas (Sierra Madre Oriental e Sierra Madre Occidental). Entre ambas as cordilheiras encontra-se o planalto central mexicano que representa um lugar fisicamente mais accessível às tropas do exército e forças estatais do que as zonas montanhosas, lugar onde os cartéis têm suas bases centrais. Porém, o domínio territorial dos cartéis mexicanos não é limitado a cidades ou zonas particulares, senão que abrangem territórios interestaduais, se intercalam com outros cartéis (o qual provoca conflitos) e não tem que ser um território necessariamente contiguo. Os cartéis de Juárez e Tijuana se encontram no norte do país, protegidos pelo deserto e zonas montanhosas; os cartéis dos Zetas, do Golfo e de Sinaloa operam em ambos os litorais do território nacional; o centro-sul do país e os estados que rodeiam à Cidade do México é uma zona confusa de insurgência, crime organizado e pequenos cartéis regionais em constante disputa (Caballeros Templários, Jalisco Nueva Generación, entre outros) e ao mesmo tempo a presença beligerante do exército e Polícia Federal (EMMERICH: 2015).

\footnotetext{
${ }^{57}$ Ver anexos 3 e 4 sobre a composição territorial do México (geografia física e geografia política).
} 
Para traçar as origens do poderoso narcotráfico moderno do México é necessário voltar a década de 1930 na qual pequenas organizações exportavam para os Estados Unidos pequenas quantias de droga produzida localmente. Na década de 1980 e com o boom mundial da cocaína, os poderosos cartéis colombianos estabelecem uma parceria com os incipientes cartéis mexicanos que serviriam de transportadores da droga através do território mexicano para a sua entrada no território estadunidense. O enfraquecimento e desarticulação dos cartéis colombianos favoreceu o crescimento exponencial dos cartéis mexicanos e passariam a dominar o trânsito de droga para os Estados Unidos sem depender diretamente dos colombianos, embora muita droga ainda seja produzida no país sul-americano (LABROUSSE: 2010). Em paralelo, os atentados contra Nova York em 2001 reforçariam a segurança na fronteira e dificultariam o transito da droga para o território estadunidense fazendo que quantidades importantes ficassem presas do lado mexicano fazendo que essa droga seja comercializada dentro do próprio território criando um novo mercado de consumo. O caso do narcotráfico mexicano é provavelmente o que mais chama a atenção no continente e no mundo já que é considerado a principal ponte de entrada de narcóticos aos Estados Unidos e um dos maiores produtores de maconha, papoula e metanfetaminas $^{58}$ (EMMERICH: 2015).

O portal de internet NarcoData ${ }^{59}$ oferece dados essenciais na compreensão da origem, evolução e complexidade da organização e distribuição dos cartéis mexicanos. Os primeiros cartéis em entrar em funcionamento foram dois: 1) a Organização de Sinaloa fundada em 1976 por Pedro Avilés Pérez ${ }^{60}$ e que seria a semente de três dos cartéis mais poderosos do país; 2) O Cartel do Golfo fundado também em 1976 por Juan Nepomuceno Guerra ${ }^{61}$ que originaria aos cartéis mais violentos e sanguinários do conflito. Posteriormente, com a queda dos grandes cartéis colombianos, o narcotráfico mexicano sofreria uma diversificação tanto na composição dos mesmos, a fragmentação de outros, a pulverização das suas atividades e o fortalecimento

\footnotetext{
58 “Segundo o Programa Nacional para o Controle de Drogas 1995-2000, o governo há destruído, nos últimos seis anos, 113.000 hectares de maconha e 72.000 de papoula e tem assegurado 237 toneladas de cocaína [...] se dá a cifra de 11.283 pessoas relacionadas em processos penais por delitos contra a saúde e se estima uma média de 100 policiais mortos por ano no combate ao narcotráfico" (EMMERIHC: 2015, p. 181-182)

${ }^{59}$ NarcoData é um portal de informação gráfica elaborado pelo jornal online Animal Político e Poderopedia; se apresenta mediante gráficos interativos e dados estatísticos a evolução e avanço dos cartéis do narcotráfico no México - o portal é accesivel em: www.narcodata.animalpolitico.com

${ }^{60}$ Pedro Avilés Perez (1938-1978): Fundador da Organización de Sinaloa, do narcotráfico em grande escala e do uso de aviões para o tráfico de droga. Genealogia del narcotráfico (1 de 5) - Primera generación: El inicio Redaccion Peninsular Digital, publicado em 10 de novembro de 2011, disponível em: http://peninsulardigital.com/cronicas/genealogia-del-narcotrafico-1-de-5/60099 - acessado em agosto de 2016.

61 Juan Nepomuceno Guerra (1915-2001): Fundador do Cartel del Golfo que começou como pequeno contrabandista de whisky. O cartel se favoreceu da corrupção para crescer. Ídem.
} 
econômico e armamentista. Para explicar melhor a evolução dos cartéis no México se usarão os esquemas ${ }^{62}$ seguintes:

Figura 1

\section{Organización de Sinaloa}

\section{Cartel de Guadalajara}

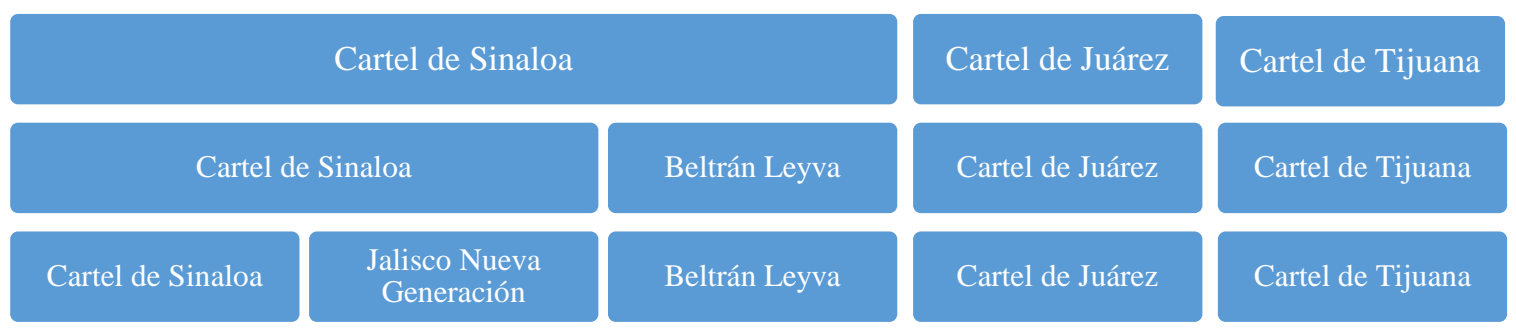

Figura 2

\section{Cartel del Golfo}

\section{Cartel del Golfo}

\section{Cartel del Golfo}

Cartel del Golfo

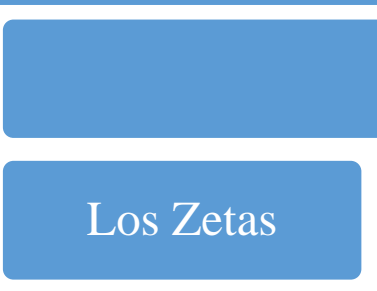

Los Zetas

\section{Los Zetas}

\section{La Familia Michoacana}

La Familia

Michoacana
Los Caballeros

Templarios

Na sequência da Figura 1 observamos a evolução da Organización de Sinaloa/Cartel de Guadalajara; entre as suas filas figuraram personagens do tamanho de Miguel Angel Félix Gallardo $^{63}$, Ernesto Fonseca ${ }^{64}$ e Rafael Caro Quintero ${ }^{65}$. Em paralelo na Figura 2 se apresenta a evolução do Cartel del Golfo que contou com nomes como Juan García Ábrego ${ }^{66}$, Osiel

\footnotetext{
${ }^{62}$ As tabelas foram construídas a partir da informação consultada no portal NarcoData.

${ }^{63}$ Miguel Ángel Félix Gallardo: Preso em 1989, ex policial estatal de Sinaloa e guardião do governador do estado. Tio dos Arellano Félix, fundadores do Cartel de Tijuana produto da divisão de plazas que Félix Gallardo fez dentro da Organización de Sinaloa. Idem.

${ }^{64}$ Ernesto Fonseca: Tesoureiro da Organización de Sinaloa, capturado em 1985 pelo Exército Mexicano. Idem.

${ }^{65}$ Rafael Caro Quintero: Preso em 1985 pelo assassinato do agente da DEA Enrique Camarena, liberado em 2013 por vícios no processo legal. A sua recaptura é ordenada em 2015 mas encontrava-se foragido para esse momento. Declaran culpable a Rafael Caro por muerte de Camarena - Ignacio Alzaga em MILENIO, publicado em 16 de janeiro de 2015, disponível em: http://www.milenio.com/policia/Caro_Quintero-sentencia_Quinteroresolucion_Caro Quintero 0 446955548.html - acessado em agosto de 2016.

${ }^{66}$ Juan García Ábrego: Preso em 1996. Sucessor de Juan Nepomuceno Guerra na frente do Cartel del Golfo. Existem dpuvidas sobre se nasceu no México ou nos EUA, isto facilitou a sua deportação aos Estados Unidos em lugar de um processo de extradição. La captura. García Ábrego, 20 años después - David CARRIZALES em EL UNIVERSAL, publicado em 14 de janeiro de 2016, disponível em:
} 
Cárdenas Guillén ${ }^{67}$ e Antonio Ezequiel Cárdenas Guillén "Tony Tormenta"68. É possível apreciar que ambos os cartéis encontravam-se localizados em litorais opostos.

No ano de 1982, o presidente estadunidense Ronald Reagan aprofunda a guerra contra as drogas e fecha a rota do Caribe que permitia o tráfico marítimo de drogas para entrar em território estadunidense no estado da Florida. Diante disso, a rota por terra através do México cobra importância e fortalece aos incipientes cartéis de Guadalajara e do Golfo. Três anos depois, em 1985, o agente da Drug Enforcement Agency - DEA, Enrique Camarena, é sequestrado, torturado e assassinado pelo Cartel de Guadalajara após a operação Rancho Búfalo que destruiu plantações de maconha e confiscou grande parte da droga propriedade de Rafael Caro Quintero. Posteriormente, o presidente mexicano Miguel de la Madrid (PRI) cria a Dirección Federal de Seguridad - DFS para capturar a Quintero e aos líderes do cartel de Guadalajara como represália pelo assassinato de Camarena ${ }^{69}$.

O assassinato de Enrique Camarena é apenas um dos eventos que propiciariam a explosão do conceito de narcoterrorismo e a articulação estratégica em torno dele. Durante a década de 1980 o governo estadunidense de Reagan radicalizou as operações contra a droga ${ }^{70}$ no continente, principalmente na Colômbia contra os cartéis de Cali e Medellín, isto em resposta ao assassinato de Camarena (SANTANA: 2012) e à explosão do voo 203 de Avianca que provocou a morte de 107 pessoas, dentre elas dois cidadãos estadunidenses. O atentado, perpetrado por Pablo Escobar, causou medo nas autoridades estadunidenses pela proximidade temporal com o atentado terrorista que derrubou o voo 103 da PanAm na Escócia, do qual o governo líbio foi responsabilizado e que causou a morte de 259 passageiros. A ligação entre narcotráfico e terrorismo começava ver as suas origens quando os Estados Unidos viram ameaçada a aviação

http://www.eluniversal.com.mx/articulo/estados/2016/01/14/la-captura-garcia-abrego-20-anos-despues acessado em agosto de 2016.

67 Osiel Cárdenas Guillén: Preso e extraditado em 2003, sucessor de García Ábrego. Extraditado aos Estados Unidos em 2007 e condenado a 25 anos de prisão - Osiel Cárdenas recibió sentencia en EU - Redacción UNIVISION, publicado em 24 de fevereiro de 2010, disponível em: http://www.univision.com/noticias/narcotrafico/osiel-cardenas-recibio-sentencia-en-eu - acessado em agosto de 2016.

${ }^{68}$ Antonio Ezequiel Cárdenas Guillén (1962-2010): Irmão de Osiel Cárdenas. Os Zetas abandonam o Cartel del Golfo durante a sua administração. É abatido em Matamoros por elementos da marinha e do exército mexicanos Muere Tony Tormenta luego de ocho horas de tiroteios con efectivos federales en Matamoros. Gustavo CASTILLO, Jesús ARANDA e Alonso URRUTIA em LA JORNADA, publicado em 6 de novembro de 2010, disponível em: http://www.jornada.unam.mx/2010/11/06/politica/007n1pol - acessado em agosto de 2016.

${ }^{69}$ Fonte NarcoData: http://gilbertoleon.io/narcodata/v01dh.html

${ }^{70}$ Como por exemplo a Diretiva de Segurança Nacional 221 que definia ao narcotráfico como ameaça de segurança naciona. A operação Blast Furnace na Bolívia para destruir plantações de coca; a operação Snowcap contra a produção de cocaína no continente e o lançamento da Iniciativa Andina para Peru, Colômbia e Bolívia. Fonte: NarcoData: http://gilbertoleon.io/narcodata/v01dh.html 
comercial, um "elemento constitutivo del estilo de vida libre de occidente" (LINTON: 2015, p. 78).

Em 1988 com a chegada de Carlos Salinas de Gortari (PRI) à presidência do México, a aproximação com Washington fica mais evidente com a negociação e posterior ratificação do Tratado de Livre Comércio da América do Norte - TLCAN. O governo de Salinas acorda com os Estados Unidos, como parte do tratado, o combate conjunto ao tráfico de drogas e começa a construção do muro fronteiriço entre México e Estados Unidos na zona de San Diego e Tijuana.

Seguindo a Figura 1, o Cartel de Guadalajara se fragmenta em 1990 após a prisão de Miguel Ángel Félix Gallardo quem tinha dividido as rotas de tráfico do cartel em três grupos principais que iriam formar cartéis independentes: Amado Carrillo Fuentes "El Señor de los Cielos" "71 no Cartel de Juárez; a família Arellano Félix ${ }^{72}$ no Cartel de Tijuana e Hector “El Güero" Palma ${ }^{73}$ no Cartel de Sinaloa com a ajuda de Ismael "El Mayo" Zambada ${ }^{74}$ e Joaquín Archivaldo Guzmán Loera "El Chapo"75. Durante os próximos sete anos, os novos cartéis se disputariam

\footnotetext{
${ }^{71}$ Amado Carrillo Fuentes (1956-1997): Conhecido como "El señor de los cielos" (O senhor dos céus) pelo uso de aeronaves para traficar droga aos Estados Unidos. Lider do Cartel de Juárez, faleceu em 1997 após uma cirurgia estética para modificar seu rosto. Porém, existem ainda dúvidas sobre a veracidade da sua morte devido à falta de provas de DNA - Después de 17 años todavia no hay pruebas de la muerte de "El señor de los cielos" - Omar SÁNCHEZ DE TAGLE em ANIMAL POLÍTICO, publicado em 9 de setembro de 2014, disponível em: http://www.animalpolitico.com/2014/09/de-que-murio-amado-carrillo-17-anos-de-su-fallecimiento-la-pgr-losabe/ - acessado em agosto de 2016.

${ }^{72}$ Famila Arellano Félix: Francisco Rafael, Benjamin, Francisco Javier, Eduardo, Ramón e Enedina.

${ }^{73}$ Héctor Palma: Antigo líder do Cartel de Sinaloa e mentor de Joaquín Guzmán. Preso pela primeira vez em 1978 e pela segunda vez em 1995. Extraditado aos Estados Unidos até junho de 2016 após cumprir a sua condena. De volta ao México, é preso por dois cargos de homicídio cometidos em 1995 - Héctor "El Güero" Palma permanecerá em uma prisión mexicana - Redacción UNIVISION, publicado em 22 de junho de 2016, disponível em: $\quad$ http://www.univision.com/noticias/narcotrafico/hector-el-guero-palma-permanecera-en-una-prisionmexicana - acessado em agosto de 2016

${ }^{74}$ Ismael Zambada: Operador de Joaquín Guzmán no Cartel de Sinaloa e posterior sucessor como líder após a terceira captura de Guzmán. Durante 40 anos há evadido às autoridades militares e policiais do México e Estados Unidos - Ismael "El Mayo" Zambada, el sócio de "El Chapo" Guzmán al que México nunca há podido capturar. Alberto NÁJAR em BBC MUNDO, publicado em 9 de janeiro de 2016, disponível em: http://www.bbc.com/mundo/noticias/2015/08/150731_secretos_narco_evade_justicia_mexico_an - acessado em agosto de 2016.

75 Joaquín Archivaldo Guzmán Loera: Considerado o narcotraficante mais poderoso e buscado do mundo e a pessoa mais buscada pelos Estados Unidos após a morte de Osama Bin Laden. De uma infância miserável, na qual vendia laranjas para sustentar a sua família, entra nas filas do crime organizado e sob a liderança de Miguel Ángel Gallardo Félix começa a ascender na hierarquia do tráfico até ser indicado como chefe da plaza do que viraria o Cartel de Sinaloa. Preso pela primeira vez na Guatemala em 1993, escaparia em 2001; preso pela segunda vez em 2014 em Mazatlán, poucos meses depois escapa de novo; capturado pela terceira vez em 2016 e atualmente espera a sua extradição para os Estados Unidos.
} 
o controle das rotas de tráfico principalmente, formando alianças ${ }^{76}$ entre eles e com a intervenção de pequenos cartéis ${ }^{77}$ do sul do país ${ }^{78}$.

Como parte dos conflitos entre os cartéis de Sinaloa, Juárez e Tijuana, Joaquín "El Chapo" Guzmán sofre uma emboscada falida no aeroporto de Guadalajara em 1993 como represália à emboscada que um ano antes Guzmán tinha tentado contra Ramón Arellano Félix. Joaquín Guzmán, perseguido pelo Cartel de Tijuana, foge para a Guatemala onde é capturado e é extraditado de volta ao México no que seria um golpe importante na estrutura do Cartel de Sinaloa. Guzmán já figurava como um dos traficantes mais importantes do país e seria encarcerado em uma prisão de máxima segurança. No mesmo ano, Pablo Escobar é morto pela Polícia Nacional na Colômbia e marca o fim do Cartel de Medellín e, dois anos mais tarde, a captura de Gilberto Rodríguez Orejuela marca o fim do Cartel de Cali.

É nesse momento que os cartéis mexicanos começam a se fortalecer. Com a captura do líder do Cartel de Sinaloa, "El Güero" Palma, e o falecimento de Amado Carrillo Fuentes do Cartel de Juárez, Joaquín Guzmán assume a liderança do cartel de Sinaloa e aumenta o seu poder para finalmente fugir da prisão de segurança máxima de Puente Grande no Estado de Jalisco em 2001. Em paralelo, Estados Unidos e o governo de Pastrana assinam o Plan Colombia.

O ano de 2000 é marcado pela derrota do PRI nas eleições federais e a sua saída do poder após 70 anos nele. O candidato do Partido Acción Nacional - PAN, o empresário de direita Vicente Fox, assume o poder e nos primeiros dias do seu mandato acontece a fuga de Joaquín Guzmán, evento que marcaria para sempre a sua administração pelas suspeitas geradas sobre uma possível negociação com o Cartel de Sinaloa. Fox empreende a reforma da estrutura de segurança do Estado com a criação da Secretaría de Seguridad Pública - SSP a qual absorveria

\footnotetext{
${ }^{76}$ Tais como a Federación 1 formada entre o Cartel de Sinaloa e Juárez sob o comando de Amado Carrillo para combater o cartel de Tijuana no final da década de 90. Por sua vez temos a Federación 2 entre os mesmos carteis, aliança que duraria até 2004, mas agora sob o comando de Joaquín Guzmán em confronto com o Cartel de Tijuana e o Cartel del Golfo, posteriormente os Zetas entrariam no conflito como cartel independente.

77 Cartel del Milenio: També conhecido como o Cartel de los Valencia, fundado em 1999 por Armando e Luis Valencia. Aliado da Federación e operando no Estado de Michoacán. A fratura do Cartel daria origem aos pequenos carateis de La Resistencia e Jalisco Nueva Generación.

Cartel de Oaxaca: Fundado por Pedro Díaz Parada na década de 70 focando no tráfico de maconha principalmente. Aliado desde 2003 com o Cartel de Tijuana.

Cartel de Colima: Liderado pelos irmãos Amezcua Contreras e focado no tráfico de drogas sintéticas através da entrada de precursores químicos vindos da Ásia para o litoral do Pacífico mexicano.

${ }^{78}$ Os dados anteriores foram consultados através do Congressional Research Service dos Estados Unidos. Para mais informação sobre os carteis mencionados e os conflitos travados no momento: CRS Report for Congress: Mexico's Drug Cartels - Colleen W. COOK - publicado em 25 de fevereiro de 2008, disponível em: http://fpc.state.gov/documents/organization/105184.pdf - acessado em setembro de 2016.
} 
as funções de controlar a venda de armas e o controle e administração da antiga Policía Federal Preventiva - PFP.

Após os ataques contra as Torres Gêmeas em 2001, o começo da guerra contra o terror e a reafirmação do combate ao narcoterrorismo, o governo mexicano assume o compromisso e cria em 2003 a Subprocuraduría de Investigaciones Especializadas en Delincuencia OrganizadaSEIDO que seria a encarregada de dirigir as investigações e captura dos membros do narcotráfico. Esse mesmo ano, Osiel Cárdenas Guillén, líder do Cartel del Golfo, é capturado e o cartel sofre uma divisão (Figura 2): O braço armado do cartel chamado "Los Zetas" se separa da organização e começa a agir como um cartel independente, altamente perigoso e sanguinário $^{79}$.

O poder e violência dos cartéis mexicanos encontrava-se em aumento e o governo mexicano parecia incapaz de contê-los, mesmo com a captura ou morte dos principais líderes, a proliferação do narcotráfico no país aumentava exponencialmente. Em 2006, após a chegada antidemocrática de Felipe Calderón ao poder, com a benção de Vicente Fox e as oligarquias empresariais, começaria uma nova etapa na estratégia de combate ao narcotráfico que marcaria o país para sempre, afundando-o na pior crise de violência e insegurança da história com a ratificação da Iniciativa Mérida e o começo da intervenção militar aberta na guerra contra as drogas.

\section{A Iniciativa Mérida e a guerra de Felipe Calderón}

Em dezembro de 2006, poucos dias após ter tomado posse como presidente da nação, Felipe Calderón anuncia o começo da Operação Conjunta Michoacán com 5.000 efetivos militares para a "[...] erradicación de plantíos ilícitos, establecimiento de puestos de control para acotar el tráfico de enervantes en carreteras y caminos secundarios, ejecución de cateos y de órdenes de aprehensión, así como ubicación y desmantelamiento de puntos de venta de drogas" $"$. Este evento marcaria o começo oficial da intervenção militar no combate às drogas no México com a participação inicial de 40.000 efetivos militares e 5.000 efetivos da Policia Federal

\footnotetext{
${ }^{79}$ Los Zetas: Grupo por Arturo Guzmán Decena "Z1" após desertar junto com outros soldados do ramo de elite do Grupo Aeromóvil de Fuerzas Especiales - GAFES, as forças especiais do Exército Mexicano, para trabalhar como o braço armado do Cartel del Golfo.

${ }^{80}$ Anuncio sobre la Operación Conjunta Michoacán - Presidencia de la Republica, discurso publicado em 11 de dezembro de 2006, disponível em: http://calderon.presidencia.gob.mx/2006/12/anuncio-sobre-la-operacionconjunta-michoacan/ - acessado em maio de 2016.
} 
(EMMERICH: 2015). O aumento exponencial da violência não demorou muito, porém, o presidente Calderón "[...] sostenía que el aumento de la violencia y la cantidad de muertos valía la pena porque demuestra que la estrategia militar estaba funcionando bien" (EMMERICH: 2015, p. 135). O operativo militar em Michoacán, focado principalmente para combater aos Zetas, provoca a resposta sanguinária característica deles e a aparição de La Familia Michoacana que entraria em confronto direto contra o cartel dos Zetas pelo controle do estado de Michoacán.

A declaração de guerra de Felipe Calderón é parte da Iniciativa Mérida, a versão atualizada para o México do Plan Colombia para o combate ao narcotráfico. No seu texto, a Iniciativa Mérida ${ }^{81}$ se apresenta como uma "parceria sem precedentes entre os Estados Unidos e México" para o combate conjunto ao crime organizado para reforçar o respeito aos direitos humanos mediante a providência de equipe e treinamento para reforçar a lei e assistência técnica de longa duração. Faz ênfase na bilateralidade do acordo e da soberania com a que o mesmo foi feito. O governo estadunidense aportou inicialmente $\$ 400$ milhões de dólares para o México, sendo aprovados posteriormente $\$ 300$ milhões em 2009 e \$450 milhões em 2010 destinados a financiar cinco componentes principais: 1) Equipes de inspeção não-intrusiva, escâneres de íons e unidades caninas; 2) tecnologias para melhorar e assegurar sistemas de comunicação que reúnem informação criminal; 3) assessoria técnica e treinamento para reforçar as instituições de justiça - visando a nova polícia, software para dar seguimento às investigações, novos escritórios para queixas dos cidadãos e programas de proteção às testemunhas; 4) helicópteros e aeronaves de vigilância para apoiar atividades de interdição e a rápida resposta das agências de segurança mexicanas; e 5) equipe, treinamento e programas de ação comunitária em nações centroamericanas para implementar medidas anti-gangues.

No âmbito militar na região, chama a atenção a pouca prevalência de conflitos internacionais nas últimas décadas, sendo de fato a única exceção a guerra entre a Argentina e o Reino Unido. Os exércitos latino-americanos se encontram principalmente envolvidos em tarefas domésticas no combate contra o narcotráfico e movimentos de insurreição (MESSARI: 2004). A Iniciativa Mérida opera através da intervenção das instituições estratégicas para a segurança nacional e internacional (desde o México pensando para os Estados Unidos) em uma visão ampla considerando questões de defesa e segurança. Essa visão ampla faz que, por exemplo, a

\footnotetext{
${ }^{81}$ Merida Iniciative - United States Department of State - Disponível em: http://www.state.gov/j/inl/merida/
} 
Secretaria de Comunicaciones y Transportes - SCT vire terreno de ação da iniciativa (EMMERICH: 2015).

É assim que, como aconteceu no caso colombiano, a pretendida rápida solução militarizada nunca chegou já que o poder de fogo do Estado não seria suficiente contra o poder de fogo dos cartéis da droga e a violência no país se espalharia. Se bem o Plan Colombia foi efetivado no país sul-americano após a desarticulação dos cartéis visando combater as FARC sob o preceito de narcoterrorismo, no México a estratégia militarizada foi aplicada diretamente contra os cartéis da droga. De 2006 em diante é perceptível o aumento de acontecimentos violentos ligados ao tráfico de drogas ou ao combate ao mesmo e, em paralelo, a fragmentação de grandes cartéis em células pequenas, porém altamente violentas e sanguinárias. Por sua vez, a captura ou morte de grandes capos não parece ter o efeito esperado (como foi o fim do Cartel de Medellín após a morte de Pablo Escobar), senão que os cartéis parecem preparados para perder ao seu líder sem serem desarticulados. Em paralelo e em segredo, o governo estadunidense começa o Operativo Rápido e Furioso no qual, o Bureau of Alcohol, Tobacco, Firearms and Explosives - ATF introduziria armas ilegalmente ao México com a intenção de armar aos cartéis e poder prendê-los após rastrear as mesmas armas.

Nos anos seguintes após o começo da Operação Michoacán, o governo de Calderón iniciaria operativos semelhantes no estado sulista de Guerrero, na cidade de Tijuana e na região conhecida como o Triángulo Dorado ${ }^{82}$. Com a guerra abertamente declarada, a resposta do narcotráfico não demora muito e em novembro de 2008 o avião que transportava ao Ministro do Interior, Juan Camilo Mouriño, cai no meio da Cidade do México provocando a morte de todos os passageiros e alguns pedestres; o evento foi oficialmente declarado um acidente por erro dos pilotos. Porém, o governo de Calderón não da marcha atrás e lança os operativos Sinaloa, Chihuahua e Nordeste provocando a fratura do grupo de Beltrán Leyva do Cartel de Sinaloa (Figura 1). Nessa mesma sequência, acontece o infame ataque no centro de Morelia no qual um grupo de traficantes jogaram granadas de fragmentação no meio da multidão que comemorava o aniversário da independência deixando um saldo de 7 civis mortos e 130 feridos.

\footnotetext{
${ }^{82}$ A região conhecida como o Triangulo Dourado se localiza na região montanhosa que abarca o sul de Chihuahua, Sinaloa e Durango. Pela irregularidade do terreno que dificulta a sua acessibilidade, tem sido um santuário de cultivo de papoula e maconha além de ser a base de operações do Cartel de Sinaloa e o esconderijo de Joaquín "El Chapo" Guzmán - Qué es el "Triangulo Dorado", la zona donde se lleva a cabo el operativo militar que rastrea a El Chapo Guzmán - Redacción BBC Mundo, publicado em 17 de outubro de 2015, disponível em: http://www.bbc.com/mundo/noticias/2015/10/151017 mexico_chapo triangulo dorado_sinaloa mexico_amv acessado em maio de 2016.
} 
Este evento foi considerado o primeiro ataque por parte do narcotráfico direcionado intencionalmente contra a população civil.

Os anos seguintes da guerra de Calderón serão caracterizados pela morte ou prisão de grandes figuras do tráfico de drogas dos quais ressaltam a morte de Arturo Beltrán Leyva ${ }^{83}$ na cidade de Cuernavaca em 2009; a prisão do filho de "El Mayo" Zambada; a captura de Edgar Valdéz Villarreal "La Barbie" ${ }^{84}$, operador do Cartel de Beltrán Leyva; a morte de "Tony Tormenta", líder do Cartel del Golfo; a morte de Heriberto Lazcano Lazcano "El Lazca" 85 , um dos soldados de elite desertores que fundaria aos Zetas; a morte de Francisco Blake Mora ${ }^{86}$, sucessor de Juan Camilo Mouriño como Ministro do Interior, após a queda do helicóptero que o transportava; o assassinato de Rafael Arellano Félix do Cartel de Tijuana; a segunda captura de Joaquín "El Chapo" Guzmán, agora o traficante mais poderoso do mundo, o seu segundo escape da prisão e a sua terceira captura seis meses depois; entre outros.

A estrutura e organização do narcotráfico mexicano também sofre mudanças como consequência da guerra: o Cartel de Sinaloa sofre uma nova fragmentação ( Figura 1) que daria origem ao cartel Jalisco Nueva Generación que operaria no estado do mesmo nome aumentando a intensidade da disputa dos cartéis da zona ocidental do país (Sinaloa, Zetas, Familia Michoacana); por sua vez o cartel da Familia Michoacana se divide (Figura 2) dando

\footnotetext{
${ }^{83}$ Marcos Arturo Beltrán-Leyva (1967-2009): Ex aliado de Guzmán Loera até 2008. O cartel de Beltrán-Leyva foi alvo da guerra contra as drogas de Calderón e o capo é abatido por elementos da marinha mexicaa na cidade de Cuernavaca em 2009 - Organización Beltrán-Leyva - Disponível no portal InSight Crime através de: http://es.insightcrime.org/noticias-sobre-crimen-organizado-en-mexico/organizacion-beltran-leyva - acessado em agosto de 2016.

${ }^{84}$ Édgar Valdéz Villarreal: Capturado em 2010. Operador e lugar tenente de Beltrán-Leyva. Extraditado aos Estados Unidos onde se declarou culpável de narcotráfico e lavagem de dinheiro - Édgar Valdez Villarreal, "La Barbie”, se declara culpable em EEUU - Redacción UNIVISION, publicado em 6 de janeiro de 2016, disponível em: http://www.univision.com/noticias/narcotrafico/edgar-valdez-villareal-la-barbie-se-declara-culpable-en-eeuu - acessado em agosto de 2016.

${ }^{85}$ Heriberto Lazcano Lazcano (1974 - 2012?): Soldado do Exército mexicano desde os 17 anos e membro do GAFES, desertor em 1998 para formar os Zetas, então braço armado do Cartel del Golfo do qual se separaria posteriormente. Abatido em 2010 por militares mexicanos. Existe polêmica pela demora para identificar o corpo, o qual seria roubado da funerária aonde se levaria a cabo a necropsia, deixando a sua morte apenas como suposição - Vida y muerte del misterioso “Lazca”, líder de los Zetas - BBC MUNDO, publicado em 9 de outubro de 2012, disponível

em: http://www.bbc.com/mundo/noticias/2012/10/121009_mexico_perfil_heriberto_lazcano_lider_zetas - acessado em agosto de 2016.

${ }^{86}$ Francisco Blake Mora (1966-2011): Ministro do Interior, sucessor de Juan Camilo Mouriño após a sua morte. Igual que o seu antecessor, a aeronave que o transportava (helicóptero neste caso) cai sem motivo aparente nas proximidades da Cidade do México. O governo de Calderón se negou, em ambos os casos, a reconhecer a possível intencionalidade da queda das aeronaves.
} 
origem aos Caballeros Templarios comandados por Servando Gómez "La Tuta" acrescentando mais um cartel na disputa.

Em 2012, Felipe Calderón transfere o poder nas as eleições federais e abandona o país após ter iniciado uma guerra que deixou à nação incendiada. O PRI volta ao poder após 12 anos como oposição através da figura de Enrique Peña Nieto ${ }^{88}$ o qual daria continuidade à guerra e agravaria a crise de segurança e violência ainda mais, porém, acrescentando o fator autoritário característico do PRI. Por sua vez, a radicalização dos cartéis e do exército na luta travada entre eles gerou uma série de ataques à população civil desde 2006 caracterizados pela crueldade e teatralidade dos mesmos. Eles serão analisados no capítulo seguinte.

Seguindo a narrativa anteriormente exposta, é evidente o padrão de crescimento e proliferação do narcotráfico no México desde os seus primórdios como pertencentes às rotas dos cartéis colombianos. Por sua vez, é perceptível o aumento da violência e radicalização dos mesmos a partir do começo da guerra militarizada por parte do Estado e a ineficiência dos recursos econômicos e preceitos ideológicos da Iniciativa Mérida. Muitas perguntas ficam abertas após ver que uma Iniciativa proposta para acabar rapidamente com os cartéis da droga acabou gerando uma guerra multipolarizada, a proliferação dos cartéis combatidos e o aumento exponencial da violência extrema. Provavelmente a pergunta mais pertinente seria: Por que a guerra?

O crescente narcotráfico mexicano encontrava-se já funcionando plenamente em uma escala transnacional como força hegemônica após a queda dos cartéis colombianos e a sua existência não era mais um assunto de segurança nacional, senão que já qualificava como assunto internacional, o qual, faria que o Estado mexicano adotasse o discurso de luta contra o narcoterrorismo como compromisso essencial. Portanto, a adoção de este modelo implicava usar e abusar do conceito de "segurança nacional" que guia a política externa dos Estados Unidos (EMMERICH: 2015).

\footnotetext{
${ }^{87}$ Servando Gómez: Capturado em 2015. Ex membro da Familia Michoacana que fundaría os Caballeros Templarios. Professor em uma escola de Michoacán e promotor da ideia da "autodefesa" original da Familia Michoacana contra o embate dos Zetas. A sua posterior entrada no mercado da metanfetamina e proximidade com a classe política de Michoacán provocaria a sua captura e o fim dos Templarios - Servando Gómez, alias "La Tuta" - Disponível através do portal InSight Crime em: http://es.insightcrime.org/servando-gomez-martinez-latuta - acessado em agosto de 2016.

${ }^{88}$ Enrique Peña Nieto: Atual presidente do México e governador do Estado de México (2005-2011), assim como deputado local (2003-2005). Alinhado com as políticas tecnocráticas de Carlos Salinas de Gortari e do PRI na sua fase neoliberal.
} 
A presidência de Calderón, severamente deslegitimada pelo controvertido triunfo nas eleições federais de 2006, precisava urgentemente legitimar-se diante de uma população profundamente dividida. A solução foi mediante o combate ao crime organizado, às drogas e a luta pelos bons costumes das famílias mexicanas. Porém, como faria Calderón para arrastar a uma nação inteira a uma guerra? O conceito de segurança nacional e "securitização" resolveria a situação para o presidente.

\footnotetext{
"En el uso de la seguridad se puede distinguir una referencia al instrumento del poder político, provisto con la capacidad de convocar a grandes masas poblacionales para hacer efectiva una determinada voluntad de los estamentos que toman las decisiones en el gobierno. Los analistas afirman que la seguridad es una calificación o etiqueta que los gobiernos asignan a determinadas cuestiones y que permiten una acción prioritaria para la que se movilizan recursos importantes y se reducen los niveles de control de información. El concepto de seguridad nacional es central en este ámbito de significación y comprende la protección del Estado frente a la agresión exterior y frente a movimientos internos que lo puedan poner en peligro" (EMMERICH: 2015, p. 138).
}

O anterior pode ser considerado como uma mutação da antiga estratégia nacionalista que o PRI utilizou para legitimar-se e perpetuar-se no poder durante 70 anos. $\mathrm{O}$ discurso beligerante de defesa da nação, das tradições e das instituições diante de um inimigo malévolo, destrutor e inumano remete à autoafirmação diante de um Outro-ameaçador e à criação de alteridades indesejáveis e extermináveis. Portanto, o discurso de Calderón priorizaria o combate ao narcotráfico como o ápice de um Outro indesejável e às drogas como a encarnação do mal para, em consequência, generalizar a ideia de "securitização" para qualquer aspecto da vida nacional, se aproveitando da característica inter-escalar do narcotráfico e a sua fácil infiltração em qualquer nível. $\mathrm{O}$ anterior, em conjunto com a fabricação de alteridades indesejáveis por parte do Estado abre a porta para que a população " [...] acepte la ruptura de las reglas del juego político [...] entonces el tema quedara securitizado y la violación a las normas será legítima e en favor de despejar la amenaza" (EMMERICH: 2015, p. 138). A pergunta é: quem é e como se define o que é uma ameaça?

Nesse contexto, alteridade indesejável por excelência é a do traficante e o combate ao mesmo é legitimado e apoiado por políticas de segurança supostamente bilaterais. Porém, as FARC, no caso colombiano, foram incluídas diretamente após um processo de de-ideologização do movimento e homologação com a categoria "traficante" por representarem uma ameaça armada 
é ideológica à existência do Estado colombiano. A abrangência do Plan Colombia e os conceitos de narcoterrorismo abrem a porta para "narcotizar" qualquer situação e fazê-la legitimamente exterminável, todo o anterior respondendo aos interesses hegemônicos tanto nacionais como internacionais.

A Iniciativa Mérida e a guerra de Felipe Calderón não diferem muito do Plan Colombia lembrando a importância que o México tem como parceiro comercial com os Estados Unidos e os interesses que o TLCAN possa ter sobre território mexicano. Em segundo lugar, é observável o fracasso, tanto na Colômbia como no México, da criação da alteridade indesejável do "traficante" já que, ironicamente, resulta muito atraente para as juventudes rurais em situação de pobreza. Situação que se complica para o Estado quando o traficante mais poderoso do mundo, Joaquín "El Chapo" Guzmán, levava uma vida de ostentação junto com a sua família depois de superar uma infância de extrema pobreza como vendedor de laranjas em Badiraguato, Sinaloa.

É evidente que a vida de traficante é lucrativa, porém perigosa, mas o preceito de viver rápido e morrer jovem resulta atraente em países nos quais as juventudes urbanas e rurais de classe baixa não tem perspectiva nem oportunidades de vida digna. A ostentação dos grandes capos e dos traficantes menores é suficiente para criar uma aura de mitificação ao redor da vida de cartel. É altamente atraente e permeia facilmente na cultura popular, é charmosa, emocionante e hedonista. Se comparado com um Estado burocrático, afastado da população, de terno e gravata e que faz campanhas que não dialogam com a realidade desses jovens ${ }^{89}$.

O Cartel de Medellín de Pablo Escobar é provavelmente o exemplo clássico do narcotraficante latino: romantizado excessivamente pela vida cheia de luxos que um capo pode ter e que foi levado várias vezes à cultura popular através da ficção como é o clássico exemplo do cubano Tony Montana em Scarface (1983) de Brian De Palma, o seriado de Netflix sobre a Pablo Escobar retratado por Wagner Moura, ou a mitificação de personagens da vida real como Jesús Malverde e o seu status como uma espécie de Robin Hood mexicano, considerado o "santo dos traficantes, o bandido generoso e o anjo dos pobres". O anterior abre uma questão importante: a ineficiência do Estado ao combater aos cartéis em diversos frentes, mesmo no campo de

\footnotetext{
${ }^{89}$ A campanha Vive sin Drogas de TV Azteca é um exemplo; o vídeo em questão apresenta uma flor animada em 3D que canta hip-hop enquanto incentiva aos jovens a se manterem longe das drogas, as quais são representadas por uma figura cheia de estereótipos do que poderiam ser consideradas as chamadas -tribos urbanas-. Vídeo disponível em YouTube através de: https://youtu.be/fqc2dm3SFVA - publicado em abril de 2008.
} 
batalha da cultura popular no qual o Estado fracassa rotundamente na sua tentativa de ser atraente e maneiro para a população jovem.

Mesmo assim, a estratégia beligerante continuaria sendo aplicada como ferramenta de legitimação do Estado e do governo de Calderón mediante o aproveitamento da noção de securitização que permitiria a criação de alteridades indesejáveis conforme o interesse do aparelho estatal. $\mathrm{O}$ anterior se sustenta no fracasso rotundo da intervenção militar e o equívoco para mantê-la vigente como única opção de luta contra os cartéis.

\section{Violência generalizada e Estado falido}

A guerra contra o narcotráfico se trava em torno ao controle dos territórios e rotas de trânsito da mercadoria e, ao mesmo tempo, os cartéis precisam do controle de territórios dentro do Estado para monopolizar a produção e comercialização do produto. $\mathrm{O}$ anterior também implica ter controle sobre a população e o uso do território. O Estado, por consequência, não está exercendo poder nos territórios dominados pelos cartéis e "[...] el crimen organizado fortalece su carácter transnacional y amenaza la soberanía del Estado mexicano, cercano a convertirse en un Estado fallido" (EMMERICH: 2015, p. 135).

As aproximações ao conceito de Estado falido $^{90}$ são muitas, porém, é possível encontrar pontos em comum que definem as características do fenômeno. Tomando ao Estado moderno como detentor da soberania interna e projetado ao exterior como ator internacional através do reconhecimento de outros Estados, um Estado falido teria deficiências essenciais nesses dois pilares. No âmbito interno não haveria a capacidade de garantir condições básicas de vida para os cidadãos tais como a segurança, a ordem ou o acesso à justiça. Identifica-se também a corrupção do sistema e o controle do mesmo por parte de oligarquias e o afastamento da classe política do resto da população. As instituições de representação cidadã sofrem como consequência do anterior e perdem a sua função original, abandonando aos cidadãos ou tornando-se contra eles.

“Daniel Thürer entiende que el término 'failed states' no se aplica solo al gobierno central, sino que también se refiere a que las demás funciones del Estado han colapsado. Los 'failed states' son producto del colapso total o

\footnotetext{
$90 \mathrm{O}$ conceito de Estado falido utilizado na presente dissertação se articula a partir do que é considerada o funcionamento e as condições normais de um Estado que providencia, através das suas instituições, acesso à justiça, alimentação, saúde e outros serviços básicos. A falência do Estado acontece quando as instituições são incapazes de cumprir essas funções básicas e são substituídas por outras formas de organização paraestatais.
} 
parcial de las estructuras y/o instituciones de poder encargadas de mantener el orden y el imperio de la ley en un país, proceso usualmente acompañado por una escalada de violencia" (EMMERICH: 2015, p. 35).

$\mathrm{O}$ anterior tem um alto grau de perigo levando à consideração que uma parte fundamental do funcionamento do Estado encontra-se no monopólio legitimo da violência através das instituições de segurança tais como as distintas corporações policiais e as próprias Forças Armadas (EMMERICH: 2015). Essas instituições não são alheias à falência da estrutura interna de um Estado e, no caso mexicano, provoca a perda do monopólio da violência diante do poder de fogo do narcotráfico. Os cartéis começam a exercer a sua soberania em territórios inteiros que foram tomados do controle do Estado através da violência e do uso da força contra os cidadãos abandonados pelas instituições estatais e, ao mesmo tempo, as tentativas do Estado de retomar o controle geram um clima bélico no qual os cidadãos estão no meio.

Norberto Emmerich (2015) oferece uma lista de características que um Estado falido apresentaria seguindo o teorizado por Robert Rotberg ${ }^{91}$; dentre elas destacam: a) o Estado não consegue controlar todo o seu território, há amplas zonas do país que estão fora do controle do poder estatal e o controle do Estado se limita a zonas estratégicas e à própria capital; b) há descontentamento da população que se manifesta em eventos violentos contra o governo; c) os confrontos são motivados pelo controle de determinados recursos naturais (no caso mexicano são as zonas de cultivo de droga); d) aumento marcado da violência de grupos criminosos os quais começam controlar territórios; o Estado pode adquirir uma atitude criminal contra os próprios cidadãos; e) diante da incapacidade do Estado de providenciar condições de vida básicas, surgem atores não estatais que providenciarão essas condições (i.e.: as autodefesas cidadãs providenciando segurança); f) instabilidade econômica; g) assimetria na relação dos três poderes na qual o Executivo e hegemônico; h) corrupção sistêmica (EMMERICH: 2015, p. 36-37).

As características listadas são observáveis no México desde antes do começo da guerra de Felipe Calderón e outras foram evoluindo favorecidas pelas condições do clima bélico que o conflito trouxe consigo. A decisão de utilizar às forças armadas para tarefas de guerra dentro do próprio território do Estado-nação acabou por debilitar ao próprio Estado e fortalecer aos cartéis da droga. O uso do monopólio da violência, ironicamente, criou espaços vazios dentro

\footnotetext{
${ }^{91}$ Rotberg, R. (2002). Failed States in a World of Terror, Foreign Affaires, New Cork, Julho/Agosto.
} 
do território nacional nos quais o Estado não exercia mais soberania e entregava as suas funções aos cartéis.

A decisão beligerante de Calderón provocou o aumento descontrolado da violência ao longo do território e provocou uma epidemia de homicídios que, segundo dados da revista médica britânica The Lancet $^{92}$, duplicou o número de mortes violentas de 2007 a 2012 passando de 9.34 a 18.157 assassinatos por cada 100.000 habitantes com 136.234 mortos desde 2007 e 30.000 desaparecidos, segundo cifras oficiais ${ }^{93}$, em conjunto com 1.65 milhões de pessoas deslocadas por causa do conflito ${ }^{94}$. O anterior derivado da falência das instituições de justiça e segurança em conjunto com a incapacidade do Estado mexicano de garantir condições básicas de vida civil e não reconhecer essa epidemia de homicídios como um assunto de saúde pública.

Em paralelo, a organização Human Rights Watch - $\mathrm{HRW}^{95}$ ressalta o problema das pessoas desaparecidas por causa do conflito e estima o número em $25.000^{96}$ durante o governo de Calderón (2006-2012), número que superaria totalmente qualquer cifra de desaparecidos durante as ditaduras latino-americanas ${ }^{97}$ ressaltando também a negativa do governo ${ }^{98}$ para

\footnotetext{
92 Violence and homicide in Mexico: a global health issue - Jennie Gamlin em The Lancet (385), publicado em 14 de fevereiro de 2015, disponível em http://www.thelancet.com/journals/lancet/article/PIIS01406736(15)60234-3/fulltext. Acessado em abril de 2016.

${ }_{93}$ Informe de víctimas de homicidio, secuestro y extorsión 2014: Secretaria de Gobernación - SEGOB, Secretariado Ejecutivo del Sistema Nacional de Seguridad Pública - SENESP, publicado em 19 de dezembro de 2014, acessado em abril de 2016, disponível em: http://www.secretariadoejecutivo.gob.mx/work/models/SecretariadoEjecutivo/Resource/1406/1/images/Victimas publicacionnov14.pdf

Causas de defunción: Porcentaje de muertes por homicidio con respecto al total de muertes violentas por entidad federativa y sexo, 2004 a 2014 - Instituto Nacional de Estadística y Geografía - INEGI: http://www3.inegi.org. $\mathrm{mx} / \mathrm{sistemas} / \mathrm{sisept} / \mathrm{default}$.aspx? $\mathrm{t}=$ mvio24\&s=est\&c=22651

${ }^{94}$ Public Health and International Drug Policy - The Lancet Comissions em The Lancet (387), publicado em abril de 2016, disponível em: http://www.thelancet.com/pdfs/journals/lancet/PIIS0140-6736(16)00619-X.pdf Acessado em abril de 2016.

${ }^{95}$ Vanished: The Disappeared of Mexico's Drug War - Nick STEINBERG em Human Rights Watch / Foreign Policy, publicado em 6 de janeiro de 2014, disponível em: https://www.hrw.org/news/2014/01/08/vanisheddisappeared-mexicos-drug-war - Acessado em abril de 2016.

96 "Nor did Peña Nieto offer a plan for dealing with one of the most nefarious aspects of Mexico's drug war: disappearances. This omission was particularly troubling given that, on Nov. 29, 2012 - two days before Peña Nieto was sworn in - a government list had been exposed showing that more than 25.000 people had disappeared or otherwise gone missing during Calderón's term" Ídem.

97 "Augusto Pinochet's government in Chile disappeared more than 3.000 people; Argentina's military junta disappeared 10.000, by official counting. During Mexico's dirty war from the late 1960s to the early 1980s, the PRI government disappeared an estimated 500 people - some of whom were thrown alive from Air Force planes over the Pacific Ocean. If even half of the cases on the leaked 2012 list (25.000) were real, they would constitute one of the worst waves of disappearances in the Americas in decades" Ídem.

98 "I've found that, if these disappearances share anything in common, it is that the government has done almost nothing to try to find the missing. And it has consistently failed to pursue the obvious lines of evidence that, in case after case - including Israel Arenas Durán's - point to the collusion between the cartels and the very soldiers and police sent to combat them "Ídem
} 
investigar os casos de desaparição e a criminalização das vítimas ${ }^{99}$ (falência institucional de acesso à justiça) e o envolvimento das autoridades nas mesmas desaparições, inclusive ligados aos cartéis. Por sua vez, a cadeia de televisão pública estadunidense Public Broadcasting Service - $\mathrm{PBS}^{100}$ ressalta a comparação entre a guerra contra as drogas no México e as guerras no Afeganistão e Iraque. Embora o México não se encontre em uma guerra formalmente declarada pelo Congresso da União, os 164.000 mortos desde 2007 estimados pela PBS superam aqueles do Afeganistão após a invasão estadunidense de 2001 com 26.000 vítimas mortais e se aproxima das cifras conservadoras do conflito no Iraque que estimam 160.500 mortos desde 2003 (embora outras cifras se aproximem aos 500.000) ${ }^{101}$.

Em quanto à luta pelo controle do território, o avanço do narcotráfico e a proliferação dos braços armados dos cartéis no país é alarmante e ao mesmo tempo permite ver a localização estratégica de cada cartel em relação com o tipo de atividade que desenvolvem principalmente, seja o foco o tráfico internacional de droga, a produção da mesma ou a extração direta de renda (extorsão, sequestro, etc.). O portal NarcoData ${ }^{102}$ aporta uma visão cronológica da evolução dos cartéis e a proliferação dos braços armados dos mesmos e, por outro lado, permite ver a cronologia da ocupação e presença dos cartéis nas entidades federativas do país desde 1976 até hoje.

\footnotetext{
99 “As reports of disappearances began to surface in the first years of Calderón's drug war, his administration claimed that the people had gone missing on their own volition. Young women had run off with boyfriends or fled overbearing parents; young men had fallen in with gangs or gone into hiding after commiting crimes. When overwhelming evidence of people being taken against their will made this explanation untenable, the administration began to claim the crime were a byproduct of the turf battle between rival cartels: criminals killing criminals" Ídem.

${ }^{100}$ The Staggering Death Toll of Mexico's Drug War - Jason M. BRESLOW em PBS/FRONTLINE, publicado em 27 de julho de 2015, disponível em: http://www.pbs.org/wgbh/frontline/article/the-staggering-death-toll-ofmexicos-drug-war/ - Acessado em abril de 2016.

101 "Over the course of the wars in Afghanistan and Iraq, the number of civilian deaths has been staggering. In Afghanistan, more than 26.000 civilians are estimated to have died since the war began in 2001. In Iraq, conservative tallies place the number of civilians killed at roughly 160.500 since the U.S. invasion in 2003. Others have put the total closer to 500.000." Ídem.

102 Un país rehén: Todos los estados ocupados por el crimen organizado - Disponível em: http://narcodata.animalpolitico.com/pais-invadido/

Los carteles se fortalecen con brazos armados que arrinconan a la ciudadanía - Disponível em: http://narcodata.animalpolitico.com/brazos-armados/
} 


\section{AREAS OF CARTEL INFLUENCE, WITH SMUGGLING ROUTES}

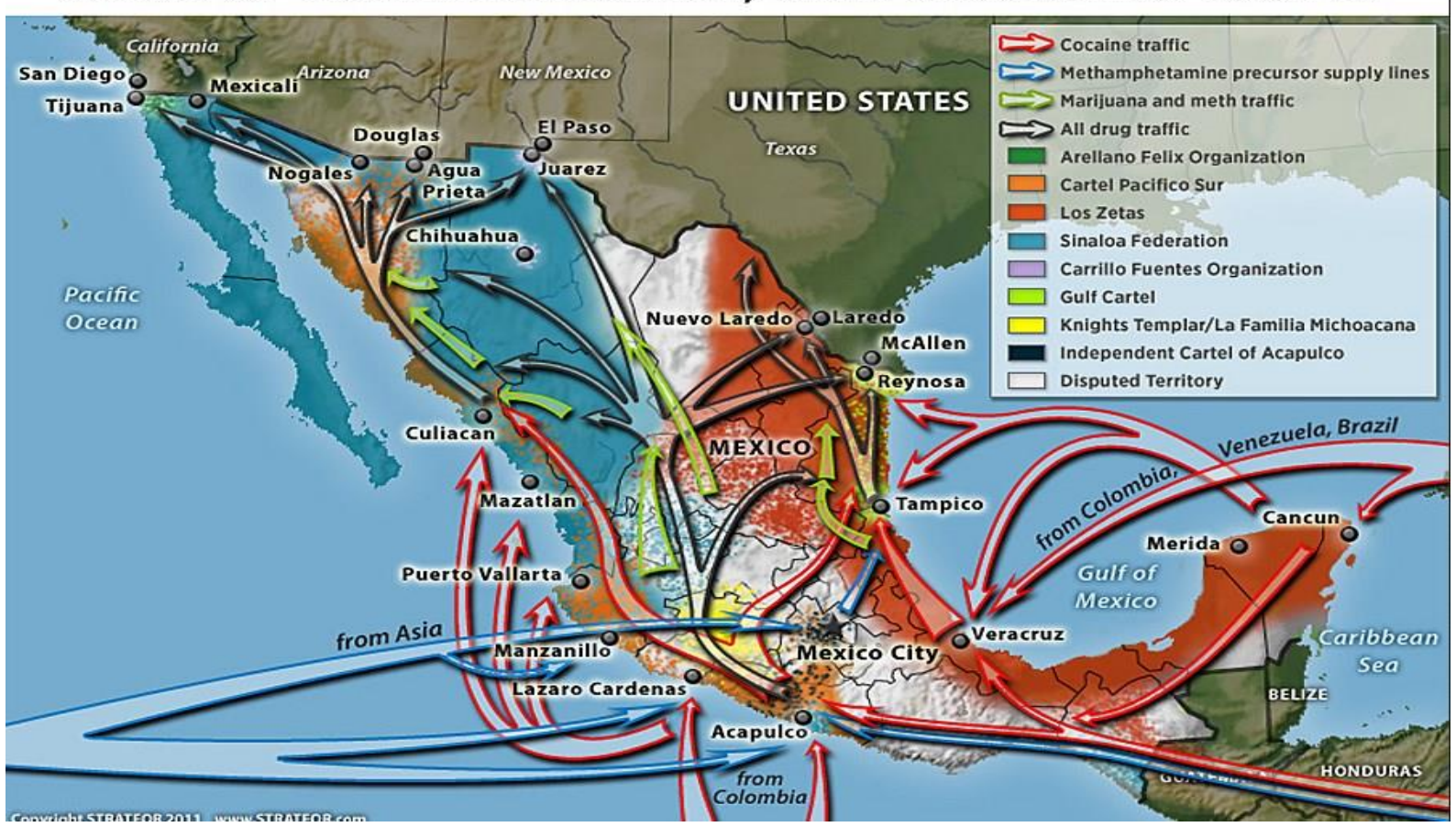

Imagem $1^{103}$

No mapa anterior é possível apreciar as zonas de operação dos cartéis e as rotas de trânsito da droga através de território mexicano. Os cartéis originais (Figura 1 e 2) de Guadalajara e do Golfo encontravam se localizados cada um em um litoral. O Cartel de Guadalajara centralizado no estado ocidental de Jalisco (litoral pacífico) e estendido para o norte nos estados de Sinaloa, Durango, Chihuahua Sonora e Baja Califórnia Norte; ocupava o Triángulo Dorado nas montanhas de Sinaloa e Durango para a produção de papoula e maconha e tinha acesso aos Estados Unidos através dos outros estados. Após a fragmentação do Cartel de Guadalajara (Figura 1), os três herdeiros (Cartéis de Sinaloa, Tijuana e Juárez) encontraram-se dividindo o mesmo território e gerando conflitos pelo controle do mesmo, sendo o Cartel de Juárez - CJ que se expandiu para o litoral atlântico e o Cartel de Sinaloa - CS, que manteve o controle do Triángulo Dorado e conseguiu se espalhar por todo o país para virar o cartel mais poderoso do mundo sob o comando de Joaquín "El Chapo” Guzmán. O CS tem presença bi oceânica e nas três fronteiras terrestres do país (Estados Unidos, Belize e Guatemala), garantindo o domínio do tráfico de drogas.

No centro do país se observa a zona em disputa entre os diversos cartéis assim como o conflito pela fronteira com Guatemala, local importante para o ingresso de drogas vindas da América do Sul. Por sua vez, a localização bi oceânica da Colômbia, como foi mencionado, favorece o

${ }^{103}$ Fonte: www.stratfor.com 
envio da droga por ambas os litorais colombianos e o ingresso das mesmas através dos dois litorais mexicanos o que os torna de alto valor para quem consiga dominá-los. No caso do litoral pacífico é o CS quem mantêm a hegemonia; o caso do litoral atlântico e do Cartel del Golfo é um pouco mais complexo.

A questão territorial do litoral atlântico está ligada ao Cartel del Golfo e a utilização de braços armados autônomos e especializados em labores de combate. Os Zetas, por exemplo, foram recrutados para a segurança pessoal de Osiel Cárdenas e para reforçar o combate contra os cartéis rivais e as forças estatais. Pouco tempo depois, o CJ e CS responderiam com a criação dos seus próprios braços armados especializados como: La Línea, FEDA e Los Pelones. O começo da guerra de Calderón em 2006 provocou um aumento dramático no número de braços armados no país, passando de 3 para 60. Estes grupos se caracterizam por não ter o tráfico de drogas como função principal, senão que fazem parte da estrutura de segurança e manutenção econômica. Além do mais, podem ser conformados por ex-militares ou ex-policiais (como os Zetas conformado por desertores do Grupo Aeromóvil de Fuerzas Especiales - GAFES) ou mesmo por policiais ou militares em ativo.

Estes braços armados especializados são, portanto, pessoas preparadas e treinadas tanto taticamente como no uso das armas. Em ocasiões, como aconteceu com os Zetas, o braço armado se separa do Cartel para formar uma organização independente. Estes últimos entraram em conflito direto com o Cartel del Golfo pelo controle do litoral atlântico e as rotas de entrada da droga vinda da América do Sul, tanto por via oceânica como por via terrestre através da América Central, assim como a luta pelo controle das rotas de entrada para os Estados Unidos através da zona de Laredo, Reynosa e McAllen. Posteriormente, produto de novas fragmentações originadas do conflito entre Zetas e Cartel del Golfo e para conter a violência destes grupos, surge La Família Michoacana e mais tarde os Caballeros Templários no estado de Michoacán, grupos que posteriormente virariam cartéis. A crueldade das organizações mencionadas provocaria o surgimento de autodefesas cidadãs em Michoacán como resposta dos civis diante das agressões dos traficantes como das forças estatais. O tema das autodefesas será tratado no próximo capítulo.

Por outro lado, a população, dentro da sua diversidade, encontra-se diante de um Estado que parece não ser capaz de providenciar segurança e qualidade de vida digna para os cidadãos e, além do mais, parece não ter o mínimo interesse em fazê-lo. O sistema partidocrático, como foi mencionado no capítulo anterior, sequestrou a soberania nacional mediante a elaboração de uma constituição fantoche e da negociação da lei entre forças políticas, além do uso de outras 
tradições fundacionais do priísmo caciquista pós-revolucionário autoritário ${ }^{104}$ que ainda prevalecem na suposta vida democrática moderna da nação. Tradições tais como a corrupção e a troca de favores eleitorais, conflitos de interesse de funcionários de alto e baixo nível e os eventos de repressão política através da força pública repressiva como o acontecido em Tlatelolco em 1968 ou Atenco em 2006. Esses vícios do sistema político mexicano mantêm ao país em uma "zona cinza ${ }^{105 "}$ a qual, por momentos, da a aparência de um país em vias democráticas, mas, ao mesmo tempo, mantem os vícios sistêmicos do autoritarismo caciquista e fazem que a população perca o interesse na simulação democrática ${ }^{106}$.

Em paralelo, estão os partidos políticos que antigamente, pelo menos, defendiam ligeiramente algum resquício de ideologia política, mas, após terem conseguido aceder ao poder que antigamente apenas o PRI ostentava (o PRD governando a capital desde 1997 e o PAN no Executivo Federal por 12 anos) causou a mudança no sistema hegemônico prísta que passou de um autoritarismo de partido único ao autoritarismo multipolar da partidocrácia e, nesse momento, as ideologias de direita ou esquerda viraram fardo e discurso populista ${ }^{107}$ tendo como consequência o questionamento da "[...] legitimidad del Estado, como la del Gobierno. Cuando el Estado funciona eficazmente solo para unos pocos, la gran mayoría comienza a rechazarlo y a deslegitimarlo” (EMMERICH: 2015, p. 37).

Parte essencial do afastamento da classe política e dos cidadãos é a herança do presidencialismo do regime priísta pós-revolucionário que foi tratado no capítulo I e que ainda consegue manter

\footnotetext{
104 "México es un claro ejemplo de la indisociable relación entre una democracia deficiente y un gobierno disfuncional. El origen de esa nociva mezcla es la permanencia de los vicios típicos del régimen autoritario corrupción política y electoral, conflictos de interés, abuso de autoridad, censura, matanzas perpetradas por la fuerza pública, tortura, violación de derechos humanos, impunidad- [...]" - Democracia y gobiernos fallidos Héctor Tajonar em Proceso, publicado em 8 de maio de 2015, disponível em: http://www.proceso.com.mx/403642 - Acessado em abril de 2016.

105 "Durante la última década, muchos países que transitaron del autoritarismo a la democracia han permanecido en lo que el politólogo Thomas Carothers ha llamado 'la zona gris', un estadio intermedio entre los dos sistemas que provoca estancamiento político y económico e impide el desarrollo democrático” Ídem.

106 "A ello debe agregarse la desconfianza ciudadana en los procesos políticos electorales. De acuerdo con un estudio de opinión solicitado por el Instituto Nacional Electoral, la mitad del electorado piensa que los procesos comiciales en el país no son confiables, el $23 \%$ opina que han sido parcialmente confiables y solo una cuarta parte (27\%) considera que si han sido confiables. El 38\% del electorado afirma que votará el próximo 7 de junio, casi la mitad (47\%) no tiene voluntad de hacerlo y $15 \%$ aun no lo decide" Ídem.

107 "Hace tiempo que los partidos políticos en México dejaron de ser representantes de la sociedad. Este distanciamiento o falta de representatividad se ha ido dando conforme los miembros de estas agrupaciones dejaron de encabezar los movimientos sociales que en su mayoría son demandas de derechos establecidos en la ley que no se cumplen [...] Metidos en sus propias agendas de poder, los partidos sufren una severa crisis de legitimidad, sobre todo los que alguna vez se nutrieron de las corrientes de izquierda [...] Los partidos políticos en general, incluyendo al PRD, han repetido las mismas prácticas de inducción, coacción y compra de votos para mantener su registro y, con ello, seguir obteniendo miles de millones de pesos del presupuesto público" - ¿Es el PRD de izquierda? - José GIL OLMOS em Proceso, publicado em 18 de junho de 2015, disponível em: http://www.proceso.com.mx/407893/el-prd-es-de-izquierda - Acessado em abril de 2016.
} 
a hegemonia do Executivo por cima dos outros dois poderes da União. É a partir dele que o caciquismo mafioso do partido se espalha através das instituições estatais. Prova do anterior é que o Presidente da República não tem a necessidade constitucional de render contas da sua administração ao Congresso da União no Informe de Governo. Antigamente, o titular do Executivo comparecia e apresentava os resultados da sua administração no Congresso da União no que John M. Ackerman ${ }^{108}$ chama de "importante exercício de equilíbrio de poderes". Desde 2007, ano em que Felipe Calderón não conseguiu colocar um pé só no Congresso pela forte polarização que a sua chegada antidemocrática ao poder, a legislação passou a exigir ao Presidente apenas a apresentação de um informe escrito que pode ser entregue pelo vicepresidente (Secretario de Gobernación), evitando qualquer questionamento e sem ter réplica.

Além do mais, a hegemonia do Executivo por cima dos outros poderes praticamente blinda à figura presidencial de qualquer tentativa de enfrentar algum processo civil ou político. $\mathrm{O}$ Artículo $86^{\circ}$ constitucional estabelece que é apenas o Congresso da União quem determinará se existe causa grave para admitir a renúncia presidencial; o artigo $84^{\circ}$ sobre os procedimentos em causa da "falta absoluta" do presidente estipula que o Secretario de Gobernación (Ministro do Interior) deve assumir o cargo interinamente e convocar novas eleições se a falta do presidente acontece dentro dos primeiros dois anos de mandato e, se for depois, o Congresso da União designará um presidente interino que concluirá o mandato e convocará eleições; e o artigo $108^{\circ}$ constitucional estabelece que o presidente, durante o seu mandato, pode somente ser acusado por traição à pátria e delitos graves da ordem comum ${ }^{109}$, ou seja: 1) traição à pátria; 2) sedição; 3) motim; 4) terrorismo; 5) sabotagem; 6) rebelião; 7) conspiração; 8) corrupção de menores; 9) pornografia; 10) lenocínio; 11) turismo sexual; 12) delitos contra a saúde; 13) formação de quadrilha; 14) homicídio doloso; 15) estupro; 16) sequestro; e 17) delitos cometidos com médios violentos como armas de fogo e explosivos.

\footnotetext{
108 "Antes, durante el periodo de la esperanza democrática de los noventa y a principios del siglo actual, el presidente de la República tenía la obligación de presentar personalmente su informe ante el Congreso de la Unión. En un importante ejercicio de equilibrio de poderes, frecuentemente recibía allí fuertes críticas y cuestionamientos de los partidos opositores. Hoy, en cambio, el jefe del Ejecutivo solamente está obligado a enviar el informe por escrito al Poder Legislativo" - Putrefacción y renovación nacional - John M. ACKERMAN em Soberanía Popular, publicado em 6 de setembro de 2015, disponível em: http://soberaniapopularmx.blogspot.com.br/2015/09/putrefaccion-y-renovacion-nacional.html - acessado em abril de 2016.

${ }^{109}$ Los delitos graves en la reforma constitucional-penal de 2008 - Juan Manuel RAMÍREZ DELGADO Instituto de la Judicatura Federal - Escuela Judicial - Revista del Instituto de la Judicatura Federal (28) 2009, disponível em: http://www.ijf.cjf.gob.mx/publicaciones/revista/28/los_delitos_graves.pdf - Acessado em abril de 2016.
} 
Do anterior é possível concluir que: a) O Congresso da União, maioritariamente priísta, altamente caciquista, clientelista e sequestrado pelos negócios da partidocrácia, é o único que pode determinar se a causa pela qual o presidente apresenta a sua renúncia é grave; b) em caso da ausência do presidente nos dois primeiros anos, o Ministro do Interior (indicado diretamente pelo Presidente após tomar posse e, portanto, próximo dos interesses presidenciais) assume o mandato e convoca eleições através do Congresso. Se a falta absoluta do presidente fosse posterior aos dois primeiros anos, o Congresso indicará a um interino que concluirá o cargo; e c) se bem os delitos mencionados são mesmo graves e nenhum Congresso, por mais vassalo que for, meteria as mãos no fogo pelo presidente acusado, existe uma suspeita legítima: no caso, quem denunciaria e levaria o processo adiante sendo que o Legislativo e Judiciário são vassalos do Executivo? Por outro lado, é curioso, que o delito de corrupção ${ }^{110}$ ou crimes fiscais não figurem como delitos imputáveis ao Presidente da República.

Com a Presidência blindada, a soberania sequestrada e as forças armadas e de segurança librando uma guerra que não aparenta ter fim próximo é difícil falar de um Estado forte. É sim um Estado autoritário sem lugar para a representação cidadã e sequestrado por grupos de poder que giram em torno ao Partido da Revolução e as oligarquias pertencentes e patrocinadoras, mas é também um Estado que perdeu controle de territórios inteiros ao poder de guerra do narcotráfico. Além do mais, lembrando as características essenciais do priísmo, encontramos a qualidade de ser integrador e reunir diversas forças e personagens, embora sejam opostas, no interior do partido para assegurar a continuidade da dominação do mesmo. Agora, se entendemos que o partido evoluiu e não funciona mais em torno da própria figura institucional de -partido político- e o entendemos como uma espécie de transcendência de instituição para lógica de funcionamento-, veremos que o PRI não é mais apenas um partido, senão que é uma essência, uma cosmovisão, um habitus ou uma serie de diretrizes e uma forma de pensar. Portanto, quando falamos da -partidocracia do sistema político mexicano- é necessário compreender que estamos falando das formas de organização priístas transcendendo os limites institucionais e integrando-se na generalidade do sistema como forma de atuação universal sem estar limitado a instituições nem cores.

É apenas pensando no sistema político mexicano de essa forma que podemos começar a pensar a evolução histórica da assimetria das alteridades no México em relação ao estado mexicano

\footnotetext{
${ }^{110} \mathrm{O}$ presidente Enrique Peña Nieto e ministros da sua administração assim como a sua própria esposa Angélica Rivera, são acusados de atos de corrupção em matéria de licitação de obras públicas - Estes casos serão analisados nos seguintes capítulos.
} 
com a possibilidade de articular a guerra contra as drogas de maneira que faça lógica o fracasso evidente e a manutenção equivocada da mesma, assim como a questão da infiltração do narcotráfico no Estado e da formação de uma forma de funcionamento simbiótica entre ambos: o NarcoEstado.

\section{Nasce o NarcoEstado}

O Estado falido, desde a perspectiva estadunidense de segurança nacional, representa uma ameaça direta como possível base de operação e atuação de grupos terroristas tanto locais como internacionais aproveitando a deficiente estrutura institucional e a fraqueza do Estado no controle dos territórios e da própria população. Em paralelo, as fronteiras internacionais viram frágeis e facilmente penetráveis por grupos considerados como ameaças em conjunto com ondas de migrantes e o prejuízo para os interesses estadunidenses nos territórios em conflito. $\mathrm{O}$ caso mexicano é uma preocupação latente para os Estados Unidos pelas ligações comerciais, culturais e territoriais de ambos os países, porém, a estratégia militarizada de combate ao narcotráfico e a Operação Fast and Furious não apenas agravaram o conflito senão que debilitaram ao Estado mexicano e fortaleceram aos cartéis da droga.

Norberto Emmerich considera que o que torna particular o caso do México é a decadência previa do próprio Estado e do autoritarismo priísta que tinha se caracterizado por ser um regime altamente clientelista e caciquista que tinha abandonado as bandeiras da justiça e igualdade social com as que tinha nascido. O narcotráfico, segundo Phillipe Delmas ${ }^{111}$, nasce como uma forma "[...] simple, inmediata, de justicia social, de equidad económica y de mínima prosperidad para todos" (EMMERICH: 2015, p. 44) que o legitima diante do camponês muito mais do que o Estado autoritário priísta que se afastou da população no decorrer das décadas. Desta forma, o narcotráfico começa a ocupar o lugar do Estado diante da população civil como provedor de estrutura social, econômica e como detentor do monopólio da violência.

Porém não foi o surgimento dos grupos de narcotráfico os quais causaram a substituição e perda de legitimidade do Estado em zonas inteiras do país, senão que foi o próprio Estado ausente o qual favoreceu o surgimento de grupos que se legitimaram através da oferta dos serviços que o Estado tinha parado de providenciar tais como segurança, trabalho e a oportunidade de ter um futuro (EMMERICH: 2015). Os governos priístas, dentro do delírio que o poder absoluto pode

\footnotetext{
${ }^{111}$ Delmas, P. (1996). El brillante porvenir de la guerra. Buenos Aires: Editorial FLACSO.
} 
causar, deram por sentado o fato de ter o domínio absoluto do país e dormiram no botim conquistado enquanto a maioria do país ficou no esquecimento da injustiça social e da falta de oportunidades. Foi aí onde o narcotráfico encontrou o berço perfeito.

\footnotetext{
"Más allá de los factores históricos como el legado colonial, el fin de la guerra fría y la globalización, los 'failed states' tienen debilidades endógenas ya que han fracasado en la creación de un consenso social y político lo suficientemente fuerte como para eliminar la necesidad de recurrir al uso de la fuerza en la vida política cotidiana" (EMMERICH: 2015, p. 39).
}

Anos depois, os acontecimentos internacionais fizeram que o poder do narcotráfico ultrapassasse ao do Estado e se estabelecesse como hegemonia em algumas regiões do país. Diante do perigo do México virar terreno de ação de grupos terroristas do oriente médio infiltrados e de cartéis mexicanos por causa da incapacidade do Estado de controlar o próprio território, os Estados Unidos implementam, com a complacência de Felipe Calderón, a Iniciativa Mérida em uma tentativa de dar suporte ao enfraquecido Estado mexicano para lidar não apenas com o crescente poder do narcotráfico, senão com qualquer tipo de dissidência ideológica ou política mediante a criminalização e catalogação desses grupos dentro do abrangente guarda-chuva do narcoterrorismo.

Porém, do plano estadunidense escaparam as variáveis que tornam particular ao caso mexicano e que foi mencionada no apartado anterior: a) a legitimidade ${ }^{112}$ diante de grandes parcelas da população que o narcotráfico possui em contraposição ao aparelhismo do Estado pelas formas de organização priístas; e b) a essência integradora das formas de organização priístas que são já parte da história política mexicana.

A primeira variável faz que, desde o começo, a guerra contra o narcotráfico estivesse perdida enquanto não houvesse uma reforma político-social que erradicasse todas as formas de organização priísta e devolvesse a legitimidade ao Estado e a soberania à população mexicana. Enquanto a segunda variável faz que, no momento atual, a guerra tenha sido perdida já pela

\footnotetext{
112 "El día 4 de diciembre de 1993, miles de personas acompañaron el féretro de Pablo Escobar el día que fue enterrado. Música, flores, comida, muchos niños y miles de mujeres llorando a lagrima viva acompañaron el féretro hasta el cementerio en las afueras de Medellín [...] Ayer en Culiacán, capital de Sinaloa, México, no había cadáver pero si el recuerdo al hijo pródigo, un campesino semianalfabeto que levantó una multinacional del crimen con presencia en 48 países y coloco en el mapa el nombre de Badiraguato, el miserable pueblo de la sierra de Sinaloa donde nació hace 56 años, pro que ahora tendrá que pasar el resto de su vida entre rejas. Una marcha de decenas de personas pidió por la liberación de Joaquín 'El Chapo' Guzmán" - México: marchas para pedir libertad de "El Chapo" Guzmán - Jacobo G. GARCIA em El Clarín, publicado em 28 de fevereiro de 2014, disponível em: http://www.clarin.com/mundo/Mexico-marchas-libertad-Chapo-Guzman_0 1093090747.html Acessado em abril de 2016.
} 
integração do narcotráfico ao aparelho estatal e o surgimento do NarcoEstado, o qual, financiado pelo capital e pelas armas estadunidenses, pode erradicar a dissidência e estabelecer o domínio absoluto.

A infiltração do narcotráfico no Estado mexicano pode ser mal-entendida se usarmos precisamente esse termo: - infiltração -, já que dessa forma estaríamos retirando qualquer culpa ao Estado e fazendo-o vítima da virulência do narcotráfico e, de passo, justificando a intervenção militar contra o mesmo. Ao invés, é importante compreender que não é o narcotráfico quem se infiltra e infecta ao Estado, senão é o Estado que negocia com ele e o integra. Enquanto Felipe Calderón se submeteu diante dos Estados Unidos ao caminho do confronto armado direto, Enrique Peña Nieto fez o que é caraterístico do priísmo.

\footnotetext{
"México tomó nota de la política de Uribe. El presidente mexicano Enrique Peña Nieto y su gabinete decidieron no seguir la estrategia calderonista de guerra contra el narcotráfico. México, con grandes dificultades, está buscando llegar a acuerdos con estos grupos delictivos no solo para cooptarlos, sino también para integrarlos al régimen político" (EMMERICH, RUBIO: 2014) ${ }^{113}$
}

O narcotráfico, plenamente funcional desde a escala local até a escala transnacional, encontra ao governo de Calderón em atitude beligerante e é obrigado a adotar estratégias de supervivência geopolíticas como foi visto na evolução dos cartéis nos apartados anteriores. O narcotráfico se aproveita dos vazios de poder deixados pela maquinaria bélica estatal, assim como dos vazios na educação, trabalho, saúde, etc. É assim que o governo de Peña Nieto, diante do impacto que o governo de Calderón deixou, apela aos antigos costumes do partido e força aos cartéis para entrarem em um processo de politização (EMMERICH: 2015).

Porém, a proximidade entre os governos do PRI e o narcotráfico não é novidade nem produto da guerra calderonista. Desde o surgimento dos cartéis mexicanos como força considerável na década de 1970, os capos do tráfico receberam lugares de atuação em impunidade por parte dos governos locais do PRI (LABROUSSE: 2010) seguindo totalmente a lógica de funcionamento do partido através da troca de favores desde o elo mais básico da cadeia da administração político-territorial: o governo municipal.

\footnotetext{
113 Álvaro Uribe: el verdadero patrón del mal - Norberto EMMERICH e Joanna RUBIO em Agencia Paco Urondo, publicado em 16 de abril de 2014, disponível em: www.agenciapacourondo.com.ar/secciones/sociedad/14331-alvaro-uribe-el-verdadero-patron-del-mal.html _ acessado em abril de 2016.
} 
Em paralelo, seguindo também a organização hierárquica do PRI no qual o Presidente da República funcionava como imperador plenipotenciário do país e líder absoluto do partido, a cadeia de favores vindas desde os governos municipais terminava nele e, portanto, era ele quem devia dar a cara ao governo estadunidense que começava a guerra contra as drogas. O jogo consistia em que "[...] cada presidente, para abrandar a hostilidade dos Estados Unidos, reprime ao cartel mais ligado ao seu predecessor e se apoia em outra organização" (LABROUSSE: 2010, p. 70). A chegada de Carlos Salinas de Gortari ao poder e a imposição da lógica neoliberal fazem que o capital do narcotráfico vire essencial para a economia mexicana mediante a lavagem e integração do mesmo à estrutura econômica do país o qual aprofundaria a simbiose entre narcotráfico e Estado priísta.

\footnotetext{
"Dos fenómenos contribuyeron mucho a esa connivencia entre la economía legal y la ilegal: la firma del Tratado de Libre Comercio de América del Norte (TLCAN) y las transformaciones de los canales de introducción de la cocaína en Estados Unidos. La firma del TLCAN tuvo como consecuencia un aumento en el tráfico de camiones entre México y EEUU para transportar productos fabricados en las maquiladoras o mercancías agrícolas. Además, los efectos de la política antidrogas llevada a cabo por EEUU junto con Colombia fueron dobles: volvieron más difícil la introducción de cocaína a través de la Florida y las islas del Caribe, y debilitaron a los carteles colombianos, que se desmembraron en entidades más pequeñas y menos poderosas" (BATAILLON: 2015, p. 60).
}

Após a queda do PRI e a entrada da direita do PAN, o narcotráfico encontrava-se já intimamente ligado ao Estado no aspecto econômico, enquanto a administração política do território continuava sendo monopólio deste último. O governo de Vicente Fox continuou o esquema priísta diante do narcotráfico, mas foi Felipe Calderón quem, diante da crise de legitimidade que o seu governo sofria, decidiu assumir o discurso estadunidense de combate ao narcoterrorismo e destinou à força bélica do Estado contra o narcotráfico, rompendo assim a pax priísta. As consequências do agir de Calderón já foram discutidas: o aumento exponencial da violência e homicídios acompanhados de crueldade extrema e "[...] el clima de terror e impunidad que reina en el país (que) ha abierto el camino a una banalización de la violencia corriente, que se ha multiplicado" (BATAILLON: 2015, p. 55) em conjunto com a radicalização e abuso de poder das forças estatais.

O governo atual do PRI de Peña Nieto continua seguindo a lógica essencial do partido pósSalinas de Gortari, essa lógica que transcendeu ao partido e virou essência da política mexicana: 
“[...] vieja política del 'desarrollo estabilizador': hacer todo con el fin de favorecer un crecimiento económico que traiga milagrosamente hábitos democráticos [...] ” (BATAILLON: 2015, p. 68) e negadora de qualquer reforma essencial desse pensamento. Peña Nieto resgatou a essência integradora do PRI e re-insertou ao narcotráfico dentro do aparelho estatal, porém, o fez com um narcotráfico muito mais forte do que era antes de Calderón. O balanço de poder mudou, o narcotráfico agora o exerce em territórios inteiros e faz parte da estrutura política básica do governo municipal, situação que foi demonstrada após o sumiço de 43 estudantes da Escola Normal Rural "Raúl Isidro Burgos" no estado de Guerrero pelas ligações de José Luís Abarca, prefeito da cidade de Iguala, e da sua esposa, María de los Ángeles Pineda, com um ex-braço armado do agora desarticulado cartel de La Família Michoacana: os Guerreros Unidos.

\footnotetext{
"Esta política del crecimiento a cualquier precio como remedio a todos los males de México ha sido también hasta ahora la de Peña Nieto. El drama es que muchos buenos expertos en la situación mexicana han sugerido soluciones para reformar el Estado mexicano y volverlo más eficaz en su lucha contra la violencia y la corrupción. Por el momento, sin éxito" (BATAILLON: 2015, p. 68).
}

A questão é que o NarcoEstado não tem pretensões de mudar nem deixar ser mudado e, pior ainda, tem o armamento adequado da Operação Fast and Furious, a crueldade extrema, a tradição autoritária, a capacidade de repressão provada, os fundos abundantes da Iniciativa Mérida e a legitimidade outorgada pelo combate ao narcoterrorismo para fazer frente a qualquer dissidência que ameace a sua hegemonia.

Com o anterior se entende que o Estado falido mexicano no marco do retorno do autoritarismo presidencialista caciquista do PRI, o qual, não funciona mais como o partido único senão que a sua essência transcendeu, permeou e modelou o sistema político mexicano, e diante de uma guerra perdida e da crescente indignação cidadã, recorreu à antiga tradição integradora do PRI pós-revolucionário para negociar com o narcotráfico a sua continuidade e a recuperação dos territórios perdidos. Ao mesmo tempo, mantem andando a maquinaria bélica do Estado, previamente justificada pelo combate ao crime organizado e patrocinada pelo dinheiro da Iniciativa Mérida, para então pensar a questão da dissidência do jeito que a alteridade foi historicamente pensada e fabricada no México: o extermínio.

A população civil virou o alvo. 


\section{A população civil e o extermínio legitimado da dissidência.}

"And I will show you something different from either

Your shadow at morning striding behind you Or your shadow at evening rising to meet you; I will show you fear in a handful of dust." (T. S. Eliot, The Waste Land, 1922)

\section{NarcoEstado mexicano}

O desgaste do clima político no México após 12 anos de governo do PAN e 6 desde o começo do combate armado ao narcotráfico geraram as condições ideais para a volta do PRI ao poder. A esquerda, após a derrota sofrida polemicamente em 2006, não soube integrar-se em uma única frente de oposição diante do PAN, enquanto este último exerceu isoladamente o poder, principalmente durante o mandato de Calderón. O ódio radicalizado entre ambas as frentes gerou um " [...] pantano político, aparentemente mediador y centrista, alimentado con las aguas negras del autoritarismo" (BARTRA: 2014, p. 57). 
O PRI, funcionando como oposição durante 12 anos e atingindo seu ponto mais baixo em umas eleições federais na debacle sofrida em $2006^{114}$ parecia haver sido condenado à relegação como força política inferior diante do poder de convocatória que Felipe Calderón da direita e Andrés Manuel López Obrador da esquerda tinham no momento. Roger Bartra (2014) aponta esse momento como a grande oportunidade que as forças da direita quanto da esquerda tiveram para sepultar para sempre ao antigo regime autoritário do PRI. Juntos, Calderón e López Obrador somaram o $71.22 \%$ do total da votação nas eleições federais de $2006^{115}$, deixando relegado ao PRI na terceira posição, embora os governos estatais e municipais ainda estivessem sob o controle do partido da revolução. Porém, segundo Bartra, foi precisamente a situação do PRI como oposição durante 12 anos que favoreceu o seu retorno ao poder em 2012, ajudado em grande medida pela estratégia bélica de Calderón e a oposição absoluta de López Obrador ao governo calderonista.

O partido da revolução antigamente não funcionava como partido político senão que era a "agencia electoral altamente centralizada de un sistema autoritario, encargada de captar a la población por medios corporativos" e ara apenas um "apéndice burocrático que se activaba durante las elecciones y que administraba con eficacia variable las dosis necesarias de fraude" (BARTRA: 2014, p. 59). O PRI, após perder a presidência e ver a sua forma hegemônica destruída sem a figura do Presidente da República, apela às suas bases estatais e municipais nas quais ainda mantinha o controle para criar, em torno da figura de Enrique Peña Nieto, um candidato mediático e carismático que iria derrotar em 2012 ao novamente candidato das esquerdas Andrés Manuel López Obrador, a única pessoa que ainda parecia manter a força e convocatória suficiente para fazer frente ao retorno da maquinaria autoritária do PRI. Por sua vez, o PAN, desvalorizado após 12 anos de infâmia e de haver defraudado a sua bandeira de “democratização", é castigado nas urnas e relegado como terceira força política ${ }^{116}$.

Á volta do PRI ao poder foi mediante votação popular. Pode se falar e deve se falar que a campanha eleitoral de Peña Nieto foi altamente impulsionada desde o coração da grande mídia,

\footnotetext{
${ }^{114}$ Da lista nominal de 71.374.373 eleitores, o candidato do PRI, Roberto Madrazo, obteve apenas 9.237.000 votos, equivalentes ao $22.23 \%$ do total. Em comparação, em 2000 quando o PRI foi derrotado pela primeira vez na sua história, Francisco Labastida obteve 13.579 .718 votos equivalentes ao $36.11 \%$ do total contra $15.989 .636(42.52 \%)$ de Vicente Fox; em 1994, Ernesto Zedillo ganhou a presidência com 17.181.651 votos (48.69\%); em 1988, Carlos Salinas de Gortari ganhou com 9.687.926 (50.70\%). Fonte: Instituto Nacional Electoral - INE - www.ine.gob.mx ${ }^{115}$ Felipe Calderón (PAN): $\quad 14.916 .927$ (35.89\%) - Andrés Manuel López Obrador (PRD): 14.683.096 (35.33\%) - Roberto Madrazo (PRI): 9.237.000 (22.23\%). A diferença entre Calderón e López Obrador foi de apenas 233.831 votos de 71.374.373 totais. Fonte: Instituto Nacional Electoral - INE - www.ine.gob.mx ${ }^{116}$ Enrique Peña Nieto (PRI): 19.158 .592 (38.21\%) - Andrés Manuel López Obrador (PRD): 15.848 .827 (31.59\%) - Josefina Vázquez Mota (PAN): 12.732 .630 (25.41\%). Fonte: Instituto Nacional Electoral - INE www.ine.gob.mx
} 
principalmente da empresa Televisa ${ }^{117}$, através da criação de um personagem de telenovela, casado recentemente com a atriz estelar da empresa, Angélica Rivera. É imporante mencionar as investigações sobre a construção do matrimônio Peña Nieto - Rivera como uma farsa levada a cabo por Televisa com a cumplicidade da Igreja Católica para criar o casal perfeito ${ }^{118}$, ou até denunciar que o hacker colombiano Andrés Sepúlveda manipulou diretamente a eleição federal de 2016 em favor de Enrique Peña Nieto ${ }^{119}$. Mas a volta do PRI, com tudo, foi por decisão popular que votou por um produto bem publicizado.

Estes são eventos inéditos na política mexicana que parecem configurar uma nova forma de fraude que o PRI não tinha implementado com anterioridade. A fraude eleitoral de $1988^{120}$ foi tão evidente que a sua implementação foi ao mesmo tempo o encerramento de uma época de fraudes tradicionais para passar ao terreno das novas tecnologias e à manipulação da imagem e tendências de pensamento dos votantes sem necessariamente recorrer à manipulação direta dos votos. Porém, apesar do anterior, o retorno do PRI ao poder foi impulsionado em grande parte pela vontade popular, a qual precisou apenas da criação de um produto bem posicionado para esquecer 70 anos de regime autoritário.

As características diferenciadoras entre o momento que o PRI deixou o poder e o momento no qual o retomou são 1) o narcotráfico: não a sua existência per se ou as reconfigurações territoriais e organizacionais, senão o poder de fogo que agora possui, o controle dos territórios e a sua capacidade de negociação como igual e não mais como entidade inferior submetida ao Estado como simples Ministério clandestino; 2) a ativação ou reativação de movimentos

\footnotetext{
${ }^{117}$ Grupo Televisa, fundado e administrado pela família Azcárraga, é um conglomerado de mídia considerado o maior do mundo hispano falante - www.televisa.com

${ }^{118}$ A equipe de investigação de Aristegui Noticias, mediante uma investigação especial, descobriu indícios de uma possível fabricação do matrimônio Peña Nieto - Rivera com a cumplicidade da Igreja Católica no México ao anular o primeiro matrimônio de Rivera de maneira irregular e em detrimento do sacerdote José Luis Salinas (finado); o futuro presidente e a atriz de Televisa se casariam pouco tempo depois no que parece a construção mediática do casal perfeito. A Rota Romana (tribunal do Vaticano) declarou que o feito pela Arquidioceses mexicana foi uma "crassa simulação de justiça"; mais informação em: El expediente secreto de la boda Peña Nieto - Rivera - Unidad de Investigaciones em Aristegui Noticias, publicado em 6 de fevereiro de 2016, disponível em: http://aristeguinoticias.com/0602/mexico/el-expediente-secreto-de-la-boda-pena-nieto-rivera/ - acessado em maio de 2016.

${ }^{119}$ Bloomberg lançou uma reportagem especial sobre o hacker colombiano Andrés Sepúlveda, agora preso. O hacker afirma ter sido parte da campanha eleitoral de Peña Nieto fazendo labores de espionagem, manipulação de imagem, sabotagem e difamação à oposição, manipulação de tendências, etc. Na Colômbia é vinculado à reeleição de Álvaro Uribe, mais informação em: Cómo hackear una elección - Jordan ROBERTSON, Michael RILEY e Andrew WILLIS em Bloomberg, publicado em 31 de março de 2016, disponível em: http://www.bloomberg.com/features/2016-como-manipular-una-eleccion/ - acessado em maio de 2016.

${ }^{120}$ Antes da criação do Instituto Federal Electoral - IFE, a organização e contagem das votações dependia do governo. Na eleição de 1988 ainda funcionava assim; durante a contagem de votos que favorecia amplamente a Cuauhtémoc Cárdenas, o sistema de cômputo "caiu" - as suspeitas até hoje apontam a Manuel Bartlett, funcionário do PRI e titular do organismo encarregado de organizar as eleições quem agiu sob ordens do presidente Miguel de la Madrid - uma semana depois, Carlos Salinas de Gortari do PRI foi declarado ganhador.
} 
cidadãos abertamente opostos ao retorno do PRI ao poder, alguns mobilizados no momento imediatamente anterior ao triunfo de Peña Nieto (como o movimento estudantil \#YoSoy132) e os movimentos preexistentes e em conflito contra o Estado priísta desde as década de 1970 (como os estudantes das escolas normais rurais influenciados pelo legado de Lucio Cabañas ${ }^{121}$ ); e 3) o Exército Mexicano nas ruas fazendo labores policiais e de guerra.

O governo de Peña Nieto teria que trabalhar considerando estas três novas variáveis, se articular com elas e entender quais seriam vantajosas e quais deveriam ser eliminadas. No âmbito político, o PRI encontrou uma direita desarticulada e desvalorizada e uma esquerda fragmentada entre figuras messiânicas, fósseis burocráticos e críticos vorazes, um mais "autêntico e puro" do que o anterior. O partido da revolução, inteligentemente se aproveitou desse clima de divisão política para dar a sua melhor cara e propor um o chamado "Pacto por México $^{122}$ ", assinado em 2012 no Castelo de Chapultepec pelo já presidente Enrique Peña Nieto e os então líderes ${ }^{123}$ dos três partidos principais (PRI, PAN e PRD).

Porém, o problema principal do "Pacto por México" é que a suposta aliança entre grupos organizados sob uma lógica priísta de funcionamento dificilmente deixa pensar na existência de agendas políticas divergentes uma da outra e, olhando para o passado, a agenda do PRI girou em torno à perpetuação no poder e da defesa ao caciquismo que faz parte da sua essência original e legitimado por ser - a Revolução - sem precisar de ser legitimado, em uma segunda instancia, pelo povo. Os grupos de organização que funcionam sob uma lógica de organização priísta, nas palavras de John M. Ackerman ${ }^{124}$, tem o único interesse de acumular riqueza se servindo do discurso de "desenvolvimento a qualquer preço" emblemático da corrupção da época de Salinas de Gortari e a população, abraçando o velho ditado de "melhor um mal conhecido que um bem por conhecer" continua votando nos - políticos que roubam, mas que sabem governar - .

\footnotetext{
121 Estudante da Escola Normal Rural de Ayotzinapa e líder da Federación de Estudiantes y Campesinos Socialistas de México - FECSM; fundador do Partido de los Pobres - PDLP e do movimento guerrilheiro Brigada Campesina de Ajusticiamiento - BCA; perseguido e torturado pela Dirección Federal de Seguridad - DFS.

122 Documento oficial disponível na página oficial do Pacto por México: http://pactopormexico.org/ através do link: http://pactopormexico.org/PACTO-POR-MEXICO-25.pdf

${ }^{123}$ Gustavo Madero (PAN), Cristina Díaz Salazar (PRI) e Jesús Zambrano (PRD).

124 "Nos mal gobierna un grupo de personas incultas, sin educación, ética o conocimiento histórico, cuyo único interés es acumular dinero y poder. Pero su ignorancia los condena a repetir la historia y mantenerse aferrados a un inmovilismo conservador que finalmente causará su contundente derrota" - El bienio de Peña - John M. ACKERMAN em La Jornada, publicado em 24 de novembro de 2014, disponível em: http://www.jornada.unam.mx/2014/11/24/politica/020a2pol - acessado em abril de 2016.
} 
Se bem a principal arma ideológica do PRI foi o pensamento nacionalista, o peso desse monumento ideológico, segundo Roger Bartra (2014), tem diminuído através dos anos, porém a cultura democrática ainda não se desenvolveu no México, em parte pela oportunidade perdida pelo PAN em 2000 e 2006 ao cancelar de vez a possibilidade de uma alternância nas formas de governar (Fox) ou suprimir a alternância política de forma antidemocrática (Calderón). O PAN, com o fardo da tradição católica e conservadora histórica do México e carente de uma intelectualidade de peso, se afastou do caminho da direita moderna enquanto o PRD e as esquerdas não conseguiram superar a polêmica derrota de 2006 nem o desdém mutuo que as distintas esquerdas têm entre si, incapazes de construir uma pauta conjunta de atuação, e, além do mais, se negaram a ter relação com Calderón e um governo que sempre consideraram espúrio (BARTRA, 2014).

\begin{abstract}
"Debido a todo ello, no fue posible una coalición de las fuerzas modernas y democráticas de la izquierda y de la derecha con el objeto no solamente de realizar reformas políticas sustanciales, sino también de auspiciar el crecimiento de una cultura alternativa, opuesta a las tradiciones nacionalistas y revolucionarias del autoritarismo institucionalizado. En esta situación trágica podemos ver otra de las razones que explican el fortalecimiento del PRI" (BARTRA: 2014, p. 65-66).
\end{abstract}

Se a esquerda e a direita não conseguiram se aliar para acabar com a herança autoritária do PRI, foi este último que se aliou com outras forças políticas para assegurar a maioria no Congresso da União e nos distintos ministérios para assim reestabelecer a hegemonia ${ }^{125}$ do Executivo Federal por cima dos outros dois poderes da federação através do alinhamento dos outros partidos no Congresso através do "Pacto por México". A partir de este momento, o novo governo do PRI poderia se focar no assunto do narcotráfico e da dissidência civil que se manifestava, literalmente, contra o seu retorno ao poder, como foi visto nos protestos violentos no dia 1 de dezembro de $2012^{126}$ quando Enrique Peña Nieto tomou posse da presidência. É

125 "Lo que hoy atestiguamos es una enorme batalla civilizatoria en respuesta al desfondamiento del poder presidencial como centro articulador de la legitimidad pública en México.” John M. Ackerman em El bienio de Peña em LA JORNADA; disponível em: http://www.jornada.unam.mx/2014/11/24/politica/020a2pol - acessado em abril de 2016.

126 \#1DMX é utilizado para referir-se à série de protestos e confrontos violentos na Cidade do México no dia da toma de posse de Enrique Peña Nieto como Presidente da República; ressaltam os confrontos violentos contra o batalhão de choque nas imediações do centro da cidade e a "Batalha de San Lázaro" fora do Congresso da União no qual Peña Nieto tomaria posse ao batalhão de choque bloquear o avanço dos manifestantes. Este dia é considerado clave na criminalização da protesta social e a ostentação do uso da força sob o "novo" PRI diante da brutalidade do agir do batalhão de choque e da polícia do DF, assim como as violações aos direitos humanos e detenções arbitrarias - Las protestas contra Peña Nieto derivan em violencia - Arturo ASCENCIÓN em Expansión CNN, publicado em 1 de dezembro de 2012, disponível em: 
sintomático haver presenciado não apenas à população revoltada e deixando de lado a ideia do "protesto pacifico", senão que foi mais sintomático ainda o alinhamento do governo do Distrito Federal (sob o controle histórico da esquerda do PRD) para com o Executivo Federal ao blindar as ruas próximas do Palácio Nacional com uma ostensiva demonstração de força bélica do batalhão de choque (Cuerpo de granaderos) e a blindagem total do Congresso da União para conter o iminente assalto da população ${ }^{127}$.

\footnotetext{
"Es imposible evitar subirnos a la máquina del tempo para viajar a las décadas de los 60's y 70's, la era mesozoica de México en la que los dinosaurios dominaban al país a placer con sus 'carros completos', guerras sucias, actos de corrupción y censura de las voces incomodas al sistema. Todo lo anterior, no se extinguió con aquel meteorito de hartazgo social que les cayó en el año 2000 tras el triunfo del PAN en la elección federal. Lo que si se borró de la memoria de algunos ciudadanos fue la imagen y prácticas sucias del 'tricolor'; ciudadanos que le creyeron al 'nuevo PRI' y su falsa redención, teniendo como buque insignia al Presidente más joven de la historia acompañado de rostros nuevos que no resultaron ser más que costales llenos de mañas jurásicas para mantener el poder y enriquecerse a costa del erario" $" 128$.
}

O novo Estado forte de Peña Nieto tinha dois enormes problemas na sua porta: o narcotráfico e a dissidência. A suposta "força" do Estado se vê relativizada diante do poder de fogo do narcotráfico que tem a capacidade de confrontar até às próprias forças armadas e diante também da sociedade civil organizada tanto criticamente como combativamente. A questão central do presente assunto é que o Estado não pode agir com fortaleza e submeter aos dois bandos que o confrontam, tem que fazer um sacrifício e negociar em simetria com um dos dois para conseguir manter o controle da nação. Portanto, a pergunta é: com quem foi que negociou e contra quem direcionou o extermínio? Como já foi explicado nos capítulos anteriores, a população civil não é um ente de negociação para o partido da revolução já que o partido a representa essencialmente e sem discussão ao ser a encarnação institucional da Revolução. Os cidadãos “entregamos" a nossa soberania aos Poderes da União e aos seus agentes através da farsa constitucional de 1917 e, portanto, o Estado não tem necessidade nenhuma de renegociar um

http://expansion.mx/nacional/2012/12/01/yosoy132-y-otros-grupos-protestan-en-el-congreso-contra-pena-nieto acesasdo em abril de 2016.

127 "El uso de la fuerza pública ha sido la característica principal de Peña Nieto desde que tomó posesión como presidente. Con esa política de palo y zanahoria, de premiar a los amigos y de castigar a los enemigos, es como se ha mantenido en el poder estos cuatro años" - Al despeñadero - José GIL OLMOS em PROCESO, disponível em: http://www.proceso.com.mx/437051/al-despenadero - acessado em abril de 2016.

128 ¿El regreso del presidencialismo absolutista? - Alejandro GÓMEZ em La Serpiente Desplumada, publicado em 18 de março de 2015, disponível em: https://laserpeintedesplumada.wordpress.com/2015/03/18/el-regreso-delpresidencialismo-absolutistal - acessado em abril de 2016. 
pacto que já foi feito há quase um século ${ }^{129}$. O narcotráfico, pelo contrário, não é apenas um negócio transacional altamente lucrativo, senão que o combate ao mesmo traz benefícios econômicos e militares através da Iniciativa Mérida. É importante lembrar também que o narcotráfico nos seus primórdios foi integrado ao partido através da sua concatenação com a célula primordial de administração político-territorial: o município.

A guerra de Felipe Calderón rompeu com essa lógica priísta e atacou militarmente aos cartéis em uma estratégia sumamente mal concebida que procurava essencialmente a legitimação ${ }^{130}$ do governo diante da polarização que seu controvertido triunfo eleitoral de 2006 deixou, além do discurso conservador e católico característico do PAN que, como foi mencionado, também o impediu de fazer alianças com a esquerda para acabar com o PRI. A declaração de guerra foi o pior erro da administração de Calderón, como Norberto Emmerich afirma:

\begin{abstract}
“[...] si las definiciones son de 'combate', 'guerra', 'lucha', el narcotráfico responderá de la misma manera, sin discursos por supuesto. Se organizará y comenzará a entablar una dialéctica violenta, solo para sobrevivir a lo que considera una amenaza armada. Los términos que se utilicen en la elaboración y exposición de una política son las referencias que el 'otro' recibirá como advertencia, amenaza o recomendación.” (EMMERICH: 2015, p. 47-48).
\end{abstract}

Ou em outras palavras: se Calderón queria uma guerra, uma guerra foi o que obteve, isto sem esquecer que a guerra estará perdida a partir do momento que for considerada ganha apenas pelo fato de ter sido declarada e '[...] de um 'status quo' inestable entre los carteles del narcotráfico passamos a uma guerra abierta [...]" (EMMERICH: 2015, p. 137). A resposta dos cartéis, como foi visto no capítulo anterior, foi se preparar para a guerra através da aquisição de armamento (facilitado negligentemente pela Operação Fast and Furious) e a explosão e multiplicação dos braços armados de cada cartel. Por consequência, o narcotráfico foi forçado

\footnotetext{
129 "A continuación, para asegurar la dominación sobre los habitantes y que su poder no dependa de estos, los individuos designados establecen en las constituciones y en las leyes que los representantes no tienen por qué recibir órdenes de quienes los eligieron, en lo que se conoce como 'la prohibición del mandato imperativo', y establecen además una de esas cosas a las que les llaman 'principios', según el cual ni ellos ni los demás gobernantes pueden ser destituidos por los electores o por los ciudadanos en general, pues el 'principio' dice que "no existe la revocación de mandato" (VALDES: 2012, p. 13).

130 "La decisión del presidente Calderón de provocar una escalada en la confrontación con el crimen organizado no es algo que estuviera previsto con anticipación y para lo cual el gobierno se hubiese preparado. Nada en los programas y propuestas políticas que emergieron durante la contienda electoral de 2006 permitía prever que el candidato ganador desencadenaría una lucha de grandes proporciones contra los narcotraficantes [...] Este desenlace ocurrió como una decisión precipitada del gobierno de Calderón ante la situación crítica y, además, con el objeto de fortalecer su legitimidad, que había quedado muy debilitada tras el proceso electoral" (BARTRA: 2014, p: 70-71).
} 
a modernizar-se, os cartéis agora possuem o suficiente poder de fogo para fazer frente ao Exército Mexicano e o Estado perdeu o controle de territórios para o narcopoder ${ }^{131}$.

Esse foi o cenário que o PRI encontrou, os antigos dias do regime autoritário não existiam mais. O próprio processo de globalização, como afirma Emmerich (2015) fez a sua parte na desconstrução da hegemonia nacionalista do PRI desde a perspectiva das relações econômicas agora desligadas dos atores/agentes políticos nacionais e inseridos em um espaço transnacional, afastado do nacional. O narcotráfico fez essa transição e se articulou em distintas escalas de funcionamento no território virando uma empresa transnacional o que faz dela, em termos econômicos globais, não mais dependente assimétrico do Estado.

O anterior, em conjunto com o poder de fogo dos cartéis, deixa ao Estado na particular posição de negociar em situação de iguais com o crime organizado. Porém, é necessário lembrar as dimensões do narcotráfico que vão além do simples tráfico de drogas, uma ideia que o mesmo Emmerich tinha considerado: falar de narcotráfico não é falar de drogas ou crime, é falar de Estado e política. Mas que foi o que levou o PRI de Enrique Peña Nieto a negociar com o narcotráfico? Se bem já foi mencionada a tradição integradora do partido em busca do desenvolvimento a qualquer preço -, a população civil teve um papel importante no pacto entre cartéis e Estado. O clima de violência extremo produto da guerra de Calderón provocou que a população, considerando-a no nível municipal, considerasse mais plausível o estilo de governar do período prísta, o qual se fundava na "[...] complicidad de los criminales con las policías municipales que se encargan de mantener cierto orden en los mercados ilegales e informales" (BARTRA: 2014, p. 69). A guerra de Calderón rompeu essa lógica de administração do território e criou vácuos de poder que foram necessários preencher de qualquer jeito, principalmente por médio da violência. Estes vácuos de poder se juntaram aos antigos vícios das deficientes administrações municipais do PRI que se traduzem em marginalidade, pobreza, deficiente ou nula educação, miséria, fome, desemprego e falta de perspectivas.

A nostalgia, segundo Bartra, pela organização priísta fundada no “ [...] sistema de mediación política basado en la negociación del incumplimiento selectivo de la ley” (2014, p. 69) fez que o cidadão comum atingido pela violência da guerra sentisse que a volta do PRI, o partido

\footnotetext{
${ }^{131}$ Roger BARTRA (2014, p. 68) alerta sobre a criação de vazios tanto na administração política como nos territórios produto do uso da força militar e a própria militarização da polícia; vazios que serão preenchidos pelos traficantes na estrutura política e pela disputa territorial estritamente entre cartéis deixando de fora às forças estatais: "[...] la represión desatada por el ejército, la marina y la policía federal ha provocado un desequilibrio en los grupos de narcotraficantes (...) ha ocasionado un aumento de la competencia por llenar los huecos y la consiguiente violencia con que se enfrentan entre sí las organizaciones criminales que se disputan los territorios."
} 
negociador e integrador, seria o único jeito de fazer uma trégua com os cartéis da droga. $\mathrm{O}$ narcotráfico, agora fortalecido e politizado, preencheu os vazios no aparelho estatal de administração política do território que a guerra calderonista deixou e se apresentou mais como uma solução do que o foco original do conflito, demonstrando que efetivamente o narcotráfico não é falar de drogas, senão de política e Estado e da "[...] capacidad de dar respuesta a interrogantes históricos que el Estado nacional ya no puede vehiculizar" (EMMERICH: 2015, p. 30).

A essência e êxito do NarcoEstado, tomando três ideias principais de Norberto EMMERICH (2015), se funda na sinceridade e pragmatismo que o narcotráfico politicamente aporta ao Estado: elimina os discursos políticos românticos que já ouvimos tantas vezes e pouca coisa significam e traz o discurso da vida real que o político comum desconhece, isto é também uma qualidade que o faz atrativo para a juventude. Por outra parte o seu mesmo pragmatismo faz dele algo em que pode se acreditar e, finalmente, faz as coisas acontecerem, ou em palavras de Emmerich: "[...] el narcotráfico responde a la parálisis del Estado de derecho, que todo promete y nada cumple, con el dinamismo del estado (stato) sin derechos, que nada promete y todo lo cumple” (2015, p. 33).

O que podemos esperar de um Estado historicamente definidor das alteridades desejáveis ou indesejáveis articulado extraoficialmente com o narcotráfico? Nada de bom se considerarmos que ambos têm tendência de eliminar passiva ou ativamente à dissidência ou oposição. Pior ainda se lembrarmos que as Forças Armadas foram jogadas na rua em labores policiais e bélicas, legitimadas diante da população por via do combate ao crime organizado e, por outra parte, financiadas e estimuladas pela Iniciativa Mérida.

\section{Estado de Exceção: a legitimação do extermínio da dissidência}

Desde o início da guerra de Calderón, a violência no país tem atingido níveis inéditos. O uso indiscriminado da Policía Federal, do exército e da marinha criaram um ambiente de guerra nos territórios em conflito como consequência dos confrontos com os agora modernizados cartéis da droga. Os vazios deixados nas estruturas do narcotráfico provocaram um “[...] aumento de la competencia por llenar los huecos y la consiguiente violencia con que se enfrentan entre si las organizaciones criminales que se disputan los territorios" (BARTRA: 2014, p. 68). Porém, esse clima de violência e terror tem utilidade? E se a tiver, para quem é útil a sensação de horror de viver em zonas de guerra sob o acosso do abuso de poder dos 
militares e do narcoterror dos traficantes? Quem se beneficia de assignar labores policiais a um militar treinado para a guerra?

"El Relator Especial (Christof Heyns ${ }^{132}$ ) observa además que es bien sabido que, en cualquier país, a los soldados que realizan labores policiales les cuesta mucho renunciar al paradigma militar. Por lo general, la forma en que han sido adiestrados hace que no sean aptos para mantener el orden público. El principal objetivo de un cuerpo militar es el de someter al enemigo valiéndose de la superioridad de su fuerza, mientras que en el enfoque de derechos humanos, que debe ser el criterio para juzgar cualquier operación policial, se centra en la prevención, la detención, la investigación y el enjuiciamiento, y solo contempla el uso de la fuerza como último recurso, permitiendo el recurso a la fuerza letal únicamente para evitar la pérdida de vidas humanas. El Relator Especial advierte que la aplicación de un enfoque militar al mantenimiento de la seguridad pública puede crear una situación en la que la población civil se vea expuesta a una serie de atropellos". Informe do Relator Especial sobre as execuções extrajudiciárias, sumarias ou arbitrarias da ONU, Christof Heyns. Pág. $8 .{ }^{133}$

A estratégia bélica por parte do Estado no seu próprio território requer uma legitimação que lhe outorgue a capacidade de suspender as garantias individuais dos cidadãos visando perseguir, capturar e abater aos supostos traficantes. Porém, essa legitimidade não precisa ser decorrente de uma legalidade pré-existente, seria cair no equívoco de que de fato a legalidade outorga legitimidade per se.

Portanto, ao ser possível prescindir da legalidade para agir fora da mesma, é apenas preciso criar o foco de conflito para ter uma necessidade imperativa e auto justificada de agir fora da lei visando preservar a mesma. Essa ambiguidade favorece, por sua vez, a criação de um status necessitatis que justificaria o estabelecimento "legal" e de facto de um Estado de exceção sob o preceito de necessitas legem non habet ou - a necessidade não tem lei - (AGAMBEN: 2005). O governo de Calderón nunca precisou se justificar diante da população ou do Congresso da União ao estar agindo com medidas extremas por causa da crise de violência que o país vivia após a deflagração da guerra contra as drogas, conflito que o governo mesmo começou.

${ }^{132}$ Christof Heyns: Relator Especial da ONU sobre execuções extrajudiciárias, sumarias ou arbitrarias.

${ }^{133}$ Informe del Relator Especial sobre las ejecuciones extrajudiciales, sumarias o arbitrarias, Christof Heyns Asamblea General de la ONU, publicado em 28 de abril de 2014 (versão em espanhol), disponível em: http://www.ohchr.org/EN/Issues/Executions/Pages/CountryVisits.aspx - acessado em maio de 2016. 
De esta forma, o Estado justifica diante da cidadania e do mundo a necessidade imperativa e inquestionável de começar o combate militarizado contra os cartéis da droga como a única alternativa, assim como a justificação das baixas civis como - danos colaterais de um conflito armado -, todo o anterior pelo bem maior que decorreria do combate ao mal máximo encarnado na figura do narcotráfico. Giorgio Agamben (2005) articula o conceito de necessidade com o conceito de exceção afirmando que é a necessidade mediada por uma autoridade superior quem dispensa (exception - exceção - dispensaitio) do cumprimento da lei aos atores envolvidos na guerra contra os cartéis e, por consequência, dispensa ao Estado de respeitar as suas próprias leis constituintes. Portanto, a necessidade não cria leis novas nem acaba com as vigentes, senão que permite ao Estado e aos seus agentes de agirem em uma esfera de exceção da legalidade que está estabelecida legalmente na Constituição ${ }^{134}$, porém gerada a partir de uma necessidade que se auto justifica e não precisa de lei nenhuma e que é negadora de qualquer dissidência ou resistência por ser considerado ilegal.

A dissidência e o problemático - direito à resistência - são imediatamente ilegalizados pela existência do status necessitatis que dispensa ao Estado de cumprir a sua lei. Portanto a dissidência, até mesmo a - legítima -, considerando-a dentro dos padrões aceitos de oposição de um Estado que se assume democrático, fica, por sua vez, desprotegida da lei que o mesmo Estado defende mas pode escolher não cumprir quando a necessidade assim o exige. É uma necessidade que o próprio Estado pode criar ou denominar arbitrariamente já que nenhuma lei governa ao Estado de exceção por ser, essencialmente, uma exceção da lei mesma. Portanto, a dissidência ao Estado, embora não sendo o alvo oficial (no caso de Calderón eram os traficantes) podem ser objeto de perseguição ou extermínio, tal vez não legal, mas sim legitimado, lembrando que legalidade e legitimidade são, decididamente em momento nenhum, a mesma coisa.

Legalidade e legitimidade viram conceitos ambíguos e embasados quando analisados desde a lente do Estado de exceção da lei. Dentro de uma esfera de inexistência da lei do Estado, quem define o que é legal e o que é legitimo? Parece uma disputa de palavra contra palavra ou pior, de fuzil contra palavra, daqueles que possuem o poder de fogo e daqueles que aceitam o domínio dos primeiros e, nesse contexto de exceção da lei, o poder de fogo do Estado leva a vantagem.

\footnotetext{
${ }^{134}$ Artículo $29^{\circ}$ Constitucional: "En los casos de invasión, perturbación grave de la paz pública, o de cualquier otro que ponga a la sociedad en grave peligro o conflicto, solamente el Presidente de los Estados Unidos Mexicanos, con la aprobación del Congreso de la Unión o de la Comisión Permanente cuando aquel no estuviere reunido, podrá restringir o suspender en todo el país o en lugar determinado el ejercicio de los derechos y las garantías que fuesen obstáculo para hacer frente, rápida y fácilmente a la situación; pero deberá hacerlo por un tiempo limitado (...)”.
} 
Agamben considera a existência do direito à resistência como análoga ao Estado de exceção mencionando um exemplo da Constituição italiana: "When the public powers violate the rights and fundamental liberties guaranteed by the Constitution, resistance to oppression is a right and a duty of the citizen” (2005, p. 10). A resistência e a rebelião podem ser legitimas para a população, mas ilegais e ilegítimas para o Estado. Resulta paradoxal e é um buraco negro quando um próprio Estado defende o direito dos cidadãos a se rebelarem contra ele mesmo sob a inocente suposição de que o Estado reconheceria como legal e legítima a rebelião contra ele. Resulta muito mais inocente ainda acreditar que um partido que se assume como a Revolução institucionalizada aceitaria a dissidência e oposição sem considerá-las como a contrarrevolução. Portanto, diante dessa zona cinza conceitual da - legalidade - e da - legitimidade - em um contexto de Estado de exceção, a questão se reduz à sua expressão mais primordial: quem tiver o monopólio da violência decide o que é legitimo sem se importar com fardos legais.

Como menciona Agamben (2015), a problemática do Estado de exceção é a sua proximidade quase carnal com a guerra civil e a insurreição interna, sendo a guerra civil o oposto total das condições normais de um Estado e, portanto, a falta absoluta de controle. Por sua vez, o Estado de exceção seria o cenário de vazio legal criado de propósito por um Estado para combater os conflitos internos extremos. De essa maneira, o autor defende a existência plausível do que denomina de "guerra civil legal ${ }^{135 " ~ q u e, ~ m e d i a n t e ~ o ~ e s t a b e l e c i m e n t o ~ d e ~ u m ~ E s t a d o ~ d e ~ e x c e c ̧ a ̃ o, ~}$ mesmo sem o protocolo contemplado na Constituição, isto é, extraoficial ou de facto, permitiria ao Estado o extermínio legitimado de adversários políticos ou de parcelas da população que não se integram no projeto do Outro-hegemônico e, afirma, é uma prática comum dos Estados atuais, embora se assumam como democráticos.

O que acontece, portanto, com o narcotráfico e a população civil dissidente diante das aproximações diferenciadas do governo de Calderón e do governo de Peña Nieto à guerra contra as drogas?

No primeiro caso, a resposta foi fácil para o governo de Calderón quando o alvo oficial era o narcotráfico, é apenas logico que o Estado tenha a legitimidade de combater belicamente ao crime organizado que se apodera de territórios, ainda mais se os traficantes possuem armamento

\footnotetext{
135 "Thus, over the course of the twentieth century, we have been able to witness a paradoxal phenomenon that has been effectively defined as a 'legal civil war' (...) In this sense, modern totalitarianism can be defined as the establishment, by means of the state of exception, of a legal civil war that allows for the physical elimination not only of political adversaries, but of entire categories of citizens who for some reason cannot be integrated into the political system. Since then, the voluntary creation of a permanent state of emergency (though not perhaps not declared in the technical sense) has become one of the essential practices of contemporary states, including so-called democratic ones" (AGAMBEN: 2005, p. 2).
} 
forte. Além do mais, é possível apreciar o status necessitatis aproveitado e criado pelo governo de Calderón para fundamentar o Estado de exceção de facto que levaria à deflagração do conflito e à escalada da violência, situação que por sua vez reafirmou o status necessitatis original e afundou ao país em uma espiral de violência.

Nos anos prévios à chegada de Calderón ao poder, o país experimentou o fortalecimento dos cartéis mexicanos produto da cronologia explicitada no capítulo anterior. A infiltração dos cartéis no aparelho estatal não era novidade, porém, era discreto e silenciado pela própria hegemonia do PRI no poder. Após a queda do regime no ano de 2000, a relação entre os cartéis e o governo federal deveria ser renegociada e, ao mesmo tempo, o PRI aproveitaria o seu status como oposição para evidenciar a relação entre narcotráfico e Estado (a mesma que o PRI inaugurou e mantinha em silêncio) visando enfraquecer ao novo governo do PAN (BARTRA: 2014). Um caso emblemático foi que Joaquín “El Chapo” Guzmán tenha escapado da prisão de Puente Grande nos primeiros anos do governo de Vicente Fox, situação que ainda levanta suspeitas dos possíveis acordos entre o Cartel de Sinaloa e a administração foxista.

De fato, Roger Bartra ironiza com o paradoxo composto por: a) a incessante propaganda do México sendo comparado com e chamado de - nova Colômbia -; b) a difusão da espetacularidade dos crimes dos grandes capos, c) o aproveitamento do anterior com fins políticos da oposição agora conformada pelo PRI e PRD e; d) que “[...] en la opinión pública mexicana dominaba la sensación y la creencia de que el país vivía en un infierno de violencia creciente" (2014, p. 67); todo o anterior em comparação com e) o descenso na taxa de homicídios que acontecia ano atrás de ano ${ }^{136}$. Com a propagação da ideia de que a transição democrática e a queda do PRI tinham quebrado a pax priísta com os cartéis (BARTRA: 2014) e a imperiosa necessidade de se legitimar diante de uma nação dividida após as eleições federais de 2006, Felipe Calderón teria encontrado o seu status necessitatis para manter a governabilidade da nação, deflagrando uma guerra legitimada pelo contexto fabricado pela oposição e dirigida contra um inimigo que se auto justificava como tal: o narcotráfico.

\footnotetext{
136 “[...] havíamos aceitado a ideia de que a violência estava aumentando no país desde tempo atrás, que era inclusive maior da que a Colômbia havia padecido no final da década de 1980. E não era assim. Não haviam dato que justificassem a sensação de insegurança na segunda metade da década de 1990 [...] Entre 1990 e 2007 a taxa nacional de homicídios havia diminuído sistematicamente, ano atrás de ano; atingiu um máximo de 19 homicídios por cada 100 mil habitantes em 1992, e então começou descer até chegar a um mínimo de oito homicídios por cada 100 mil habitantes em 2007" - Homicidios 2008-2009 La Muerte tiene permiso - Fernando ESCALANTE em Nexos, publicado em 1 de janeiro de 2011, disponível em: http://www.nexos.com.mx/?p=14089 - acessado em maio de 2016.
} 
De esta maneira, Calderón escreveria uma nova página sob a noção da famosa máxima de Carl von Clausewitz ${ }^{137}$ que concebia à guerra como a continuação da política por outros meios já que "[...] o propósito político determinará assim, tanto o propósito militar a ser atingido como a intensidade do esforço que ele exige” (1996, p. 82). Porém, como Marcelo Lopes Souza (1995) afirma por sua vez, articulando o pensamento de Clausewitz com o de Hanna Arendt, que a guerra é mesmo um sintoma de perda de poder e legitimidade e, portanto, um convite à violência $^{138}$. No caso de Felipe Calderón é sintomático que a guerra tenha sido a forma de continuar a sua política de legitimação sendo que o Estado de Calderón era fraco e confrontado por distintas vias e tenha apelado a um convite à violência diante da impossibilidade de se legitimar politicamente por outros médios.

Resulta irônico que a guerra de Calderón fez de fato o México virar o inferno que a opinião pública acreditava que era antes da deflagração do conflito.

O governo de Calderón precisou também criar a imagem do inimigo máximo do Estado e ao mesmo tempo, justificar as baixas colaterais produto dos confrontos entre as forças armadas e os cartéis. Foi uma estratégia altamente perigosa porque, de uma forma, estaria justificando a violência direcionada contra grupos particulares e seria indiferente à violência direcionada para outros grupos periféricos. Mediante o uso do conceito de securitização, governo de Calderón colocou o combate ao narcotráfico como um assunto imperativo de segurança nacional para mobilizar recursos econômicos e militares com a anuência da população civil (EMMERICH: 2015).

Se bem a fabricação do traficante como o perigo máximo para o Estado e a população não seria algo difícil de conseguir, a questão da fabricação de vítimas culpáveis ou - a criminalização das vítimas - é uma questão um pouco mais complexa. Se considerarmos, como afirma Norberto Emmerich (2014) ${ }^{139}$, que parte importante das construções históricas são feitas

\footnotetext{
${ }^{137}$ No livro On War (1996), von Clausewitz aprofunda no conceito e na natureza da guerra contemplando-a como um conjunto; "a guerra é um ato de força para obrigar o nosso inimigo a fazer a nossa vontade" (p. 75) valendose da arte e da ciência e limitada, mas sem muito efeito, pela legislação internacional; é brutal por natureza e o uso máximo e eficaz da força é vantagem por cima de tudo; leva aos extremos ao cada lado obrigar "o seu oponente fazer o mesmo que ele" (p. 77).

138 "Na verdade, consoante o pensamento de Hannah Arendt, parece mesmo que a guerra, ou a violência em geral, é inclusive várias vezes um sintoma de 'perda de poder'. '(...) toda diminuição de poder é um convite à violência - quando pouco porque aquele que detêm o poder e o sentem escorregar por entre as mãos, sejam eles governo ou governados, encontraram sempre dificuldade em resistir à tentação de substituí-lo pela violência'”. (LOPES DE SOUZA: 1995, p. 78).

139 "Las construcciones de la historia también se constituyen discursivamente y las interpretaciones de un proceso son posibles lecturas alternativas de la historia (...) Este proceso de creación de significado es mucho más agudo en los casos en que el sujeto parece comportarse como un mero 'recipiente' de discurso que no cuenta con mecanismos para elaborar su propio discurso" - Los medios de comunicación y el uso político del lenguaje -
} 
discursivamente, podemos considerar que a construção histórica do que é uma alteridade desejável e uma indesejável é feita, em parte, da mesma forma. Se acrescentarmos o fator do Estado mexicano deflagrando um conflito legitimado por um status necessitatis extraoficial (legitimar o mandato do presidente) e outro oficial (combater ao narcotráfico), com um alto número de baixas civis aparentemente alheias ao conflito, sendo que a suposta finalidade do conflito é proteger à população dos cartéis e reestabelecer a ordem do Estado, podemos fazer a pergunta: como faria o Estado para justificar e legitimar as baixas civis sem aceitar uma provável incompetência das forças armadas em questões de combate e respeito aos direitos humanos ou, mais ainda, sem aceitar que as baixas civis poderiam ter sido intencionais?

Criminalizando-as, encontrando um motivo para justificar a sua morte a partir do estilo de vida que poderiam ter levado, do local de procedência ou da situação socioeconômica. Com o poder de mobilizar recursos que a linguagem política outorga, como é a mesma opinião pública com a ajuda da grande mídia que "[...] se ha desprendido de toda pretensión de realidad” e "[...] 'crea' realidades allí donde no existen y las imponen en un auditorio pasivo y esclavizado" (EMMERICH: 2015, p.8), o governo de Calderón se aproveitou da existência previa de categorias de alteridades consideradas indesejáveis desde o olhar da população urbana, local de procedência do discurso beligerante do ex-presidente.

Como escreve Javier Sicilia ${ }^{140}$, as vítimas somos desconfortáveis e afirmam a presença da incompetência e do fracasso da suposta guerra justa que o Estado proclamou com a legitimidade que apenas um vácuo pseudo-legal pode outorgar. Criminalizar é fácil se é feito desde o centro hegemônico. Existem séculos de construção de alteridades indesejáveis que o respaldam e, de fato, parece que a vítima se auto criminaliza ao pertencer a certas categorias ou parcelas da população.

Provavelmente o momento mais infame da criminalização impulsionada pelo governo de Felipe Calderón foi a sua reação após o Massacre de Villa de Salvárcar, em Ciudad Júarez no Estado de Chihuahua em 2010, evento no qual sicários atacaram a um grupo de estudantes de entre 15

\footnotetext{
Norberto EMMERICH em Más Poder Local (20), publicado em 23 de maio de 2014, disponível em: http://www.maspoderlocal.es/portfolio/marketing-politico-estrategias-n20/ - acessado em abril de 2016.

140 "Las víctimas somos incomodas. No conozco una mejor palabra para definirnos que la que acuñó Jorge Semprún aplicándosela a sí mismo después de su liberación de Buchenwald: un revenant, un 'regresado', alguie que viene del horror y del infierno de la muerte, que los atravesó y produce a la vez miedo y compasión. Una especie de Lázaro horriblemente incómodo al que pocos quieren escuchar porque trae en sus palabras y en su carne el sufrimiento de las víctimas." - El retorno de la criminalización - Javier SICILIA em PROCESO, publicado em 5 de setembro de 2015, diponível em: http://www.proceso.com.mx/414674/el-retorno-de-lacriminalizacion - acessado em abril de 2016.
} 
e 20 anos de idade durante uma festa resultando 16 jovens assassinados. A resposta de Calderón foi eloquente: "Eran integrantes de pandillas"141.

"[...] desprecian y las criminalizan. No fue otra cosa lo que hasta marzo de 2011 hizo el gobierno de Calderón ante los reclamos del dolor. 'Si sus parientes están muertos o desaparecidos, algo habrán hecho'. 'Son criminales y se están matando entre ellos'. 'Eso les sucede por andar en malos pasos'. Una manera de decir: 'Ustedes no nos importan; sus muertos y desaparecidos son para nosotros basura, cucarachas, piojos, vida prescindible como las de ustedes que nos reclaman". Javier Sicilia. ${ }^{142}$

Reconheçamos que, de fato, é fácil conceber o discurso que afirma que o garoto de 15 anos, favelado e negro, foi morto pela polícia ou por um traficante porque "alguma coisa deve ter feito". Assim como foi fácil para Calderón e muita gente dizer que 16 "peãozinhos" de Ciudad Juárez foram assassinados por colegas de gangue. É apenas lógico, é só olhar a cidade onde eles moravam, a música que eles ouviam, o jeito de se vestir, a cor de pele, o sotaque que denota pobreza, pobreza que significa criminalidade e criminalidade que significa morte. Não está demais colocar que as armas envolvidas no massacre foram relacionadas com as armas introduzidas no México na Operação Fast \& Furious $^{143}$.

São essas categorias pré-existentes de alteridade indesejável que anestesiam o assassinato de inocentes diante do olhar do Outro-hegemônico e dos pequenos Outros que se acham hegemônicos, mas não o são. Essa distinção favorece o distanciamento dos centros urbanos do interior e legitima a guerra contra os cartéis, sem importar os assassinatos de inocentes disfarçados como - danos colaterais - já que, de alguma forma os mortos do campo nunca foram novidade. Mediante essa separação entre o - interior violento - e o - centro urbano -, e as perversas subdivisões que possam ser concebidas, todas fundadas em preconceitos raciais, ideológicos ou socioeconômicos, os habitantes das zonas urbanas, ou de setores específicos das zonas urbanas, normalizam a violência que acontece longe deles e se assumem como os protegidos do Estado no meio da barbárie que a guerra justa de Calderón tenta combater e, “[...]

141 “[...] el presidente Felipe Calderón dijo desde Japón que los 15 jóvenes asesinados eran integrantes de pandillas ", - Gómez Mont ofrece disculpas por palabras equivocadas de Calderón - Rubén VILLALPANDO em La Jornada, publicado em 9 de fevereiro de 2010, disponível em: http://www.jornada.unam.mx/2010/02/09/politica/003n1pol - acessado em abril de 2016.

${ }^{142}$ El retorno de la criminalización - Javier SICILIA. Op.Cit.

143 "Según un reportaje difundido este domingo por la cadena Univisión, las armas que cruzaron la frontera hacia México como parte de la operación 'Rápido y Furioso', fueron utilizadas en masacres como las de Villas de Salvárcar, en Ciudad Juárez, donde 16 jóvenes murieron cuando se encontraban en una fiesta en 2010” - Ligan armas de "Rápido y Furioso" con matanza en Villas de Salvárcar - Redacción Proceso, publicado em 30 de setembro de 2012, disponível em: http://www.proceso.com.mx/321297 - acessado em abril de 2016. 
como se decía de los desaparecidos en la guerra sucia de Argentina, 'algo habrán hecho', y con eso se justificaban o silenciaban crímenes de lesa humanidad” (SIERRA - SIEDER: 2015, p. 3)

A criminalização das vítimas é perversa pela própria essência da ideia, mas, no contexto do Estado de exceção de facto que o governo de Calderón inauguro, é totalmente implementável. As mortes são legítimas porque o poder de fogo do Estado assim o estabelece, são legítimas porque são medidas desesperadas em tempos extremos, são legítimas porque está se lutando por um bem maior e, finalmente, são legítimas porque no final ninguém se importa enquanto a segurança esteja garantida no olho do observador. Porém, como Javier Sicilia continua dizendo, a criminalização não apenas reafirma o extremo desconforto que as vítimas inocentes geram na beligerância de Calderón, senão que demonstram que o Estado e os seus agentes estão implicados diretamente nos assassinatos " [...] transfiriendo la responsabilidad del victimario a la víctima" 144 quando menos.

Os números gerados pela violência da guerra de Calderón são alarmantes se observarmos os efeitos que a guerra trouxe para a juventude mexicana. Uma reportagem especial de Gloria Leticia Díaz para a Revista Proceso ${ }^{145}$ indaga nas estatísticas da Red por los Derechos de la Infancia - REDIM ${ }^{146}$ através das suas publicações anuais, no caso La Infancia Cuenta en México $2012^{147}$, e oferece os seguintes dados: 1.700 homicídios de menores de 2006-2012 com 30 mil adolescentes "explorados pelo crime organizado"; 7.575 adolescentes (16-17 anos de idade) remitidos ao MP por delitos federais dos quais o $91 \%$ são homens. Os números anteriores representam, desde o olhar de Calderón, uma população enorme de pequenos gângsteres em potência, culpáveis e extermináveis. Para outros, significa o avanço alarmante do poder de cooptação da juventude que o narcotráfico tem para com as parcelas jovens da população diante do enorme fracasso do Estado em matéria de educação e proteção da infância e adolescência. Em paralelo representa também o enorme perigo que a postura criminalizante de Calderón que permitiu e legitimou a "[...] violencia que ha sacrificado a decenas de millares de jóvenes pobres en el país, cuya tortura, desaparición forzada y asesinato extrajudicial hasta ahora

\footnotetext{
${ }^{144}$ El retorno de la criminalización - Javier SICILIA. Op. Cit.

${ }^{145}$ La guerra de Calderón deja entre los jóvenes más asesinatos y violencia sexual - Gloria Leticia DÍAZ em Proceso, publicaod em 28 de novembro de 2012 disponível em: http://www.proceso.com.mx/326364/la-guerrade-calderon-deja-entre-los-jovenes-mas-asesinatos-y-violencia-sexual - acessado em abril de 2016.

${ }^{146}$ Portal oficial: http://www.derechosinfancia.org.mx/

${ }^{147}$ Disponibilizado online em formato PDF através de: http://www.infanciacuenta.org/\#/publications - acessado em abril de 2016.
} 
habían sido normalizados porque se les atribuían vínculos con el crimen organizado" (SIERRA - SIEDER: 2015, p. 3).

Porém, o que acontece quando a linha que separa ao narcotráfico do Estado começa se apagar e confundir? A resposta do narcotráfico diante da guerra foi se fortalecer militarmente, como foi mencionado, e também se politizar e preencher os vazios de poder que a guerra mesma ia deixando. Após a saída de Calderón, o governo de Peña Nieto assume a deteriorada guerra contra a droga da forma mais priísta possível: negociando e reintegrando ao agora poderoso narcotráfico, com o exército e marinha liberados nas ruas e a indiferença legitimadora que a criminalização trouxe consigo. Os eventos que serão descritos a continuação sustentam essa afirmação.

\section{As crônicas do terror}

A continuação se fará uma breve visita às crônicas do terror do narcotráfico e do Estado para com a população civil principalmente. Vale uma advertência antes de continuar: os eventos serão descritos detalhadamente para dimensionar o patamar que a crueldade dos traficantes e do Estado pode atingir.

O narcotráfico é teatral e sanguinário. Na guerra entre os cartéis as execuções e ameaças continuas são coisa cotidiana, porém, de nada servem execuções rápidas e clandestinas se não são vistas por ninguém. O terror do narcotráfico está fundado na capacidade de levar ao extremo a crueldade e o prazer pelo sofrimento humano e ser ostensivo ao respeito. Que utilidade haveria em enviar um vídeo ao cartel rival onde o executado morre rapidamente com um tiro fulminante na cabeça? O traficante faz questão de infundir terror nos rivais e na população mediante atos de crueldade extremos.

É por isso que se faz um vídeo no qual uma vítima é decapitada com uma faca sem fio, devagar e com alta qualidade de som e vídeo para ver cada corte e o vapor do sangue escapar, escutar cada grito engasgado pelo sangue e captar o momento em que a vítima perde a vida, todo o anterior acompanhado de risadas e xingamentos enquanto o carrasco bate com força na coluna 
vertebral da vítima até conseguir separar a cabeça totalmente do corpo. Talvez uma motosserra possa ser mais efetiva enquanto, de jeito mórbido, fazem às vítimas se despedirem dos entes queridos e, para aumentar o terror, as duas vítimas são colocadas lado a lado, muito próximos um do outro para que, enquanto a serra elétrica destroça o pescoço do primeiro, o segundo possa ver, ouvir os poucos gritos e sentir o sangue salpicando. Uma vez decapitada a primeira vítima, voltamos ao recurso da faca sem fio com a segunda vítima.

Agora bem, com certeza queremos acreditar que esta violência é coisa de traficante e está limitada apenas a eles, isto graças à imagem que evocam na nossa imaginação: homens, grandes, feios, com bigode, malandros e insensíveis. Bem, é normal querer acreditar isso porque de essa maneira nos sentimos alheios a essa crueldade e podemos acreditar que ainda há inocência intocada e que possivelmente o conto de fadas da "honra de bandido" exista e respeita certos limites. Porém, a paixão pelo sangue conhece a inocência daqueles que não possuem esse prazer pelo sofrimento e a sensação de poder que gera, e pior ainda, sabe aproveitá-la para infundir mais terror ainda. É por isso que se fazem vídeos no mesmo teor com mulheres como vítimas, e é por isso que um garoto hondurenho de 15 anos não está excluído de este horror e o vídeo feito permite ver a cara de terror, ouvir o choro do rapaz, permite ouvir os gritos de desespero enquanto o machete começa a cortar o pescoço, permite ouvir o último grito e não para até ver ao carrasco chutando a cabeça já desprendida do corpo enquanto se lançam ameaças aos Zetas.

Aqui o pior equívoco seria acreditar que essa violência e esse nível de crueldade não têm motivo e que são simples bestas agindo fora de controle e, pior ainda, acreditar que a empatia é algo que toda pessoa sente sem considerar que, para alguns, a empatia é uma opção e é seletiva. Seria também o equívoco de não entender que a imagem de outro ser humano como um igual não é compartilhada por todas as pessoas. O prazer tem infinidade de fontes e de veículos para consegui-lo, pode vir de coisas que as vezes podem não ser concebíveis para alguns e um ser humano pode ser um simples objeto ou veículo de produção de prazer, nada mais e nada menos. Em um contexto de decomposição social e de violência generalizada que facilita a busca por esse prazer, assassinar vira tão corriqueiro quanto ouvir música.

Esses são apenas alguns casos, a decapitação com facas ou machetes é provavelmente a forma de execução mais comum, como a abundância de vídeos na internet o demonstra, enquanto o caso da serra elétrica é mais particular. Porém geralmente os vídeos se focam em execuções individuais ou de pequenos grupos de pessoas, os grandes massacres não são filmados e são 
apenas histórias contadas por sobreviventes ou testemunhas as que permitem ter uma ideia da carnificina que aconteceu.

Nos seguintes apartados se visitarão dois acontecimentos principais, um perpetrado pelo Estado e o outro pelo narcotráfico; 1) a execução sumária extrajudicial de Tlatlaya; e 2) o massacre de San Fernando e posteriormente se analisará o caso mais emblemático do extermínio da dissidência: O sumiço dos 43 estudantes de Ayotzinapa.

\section{Tlatlaya - Foi o Exército Mexicano}

No dia 30 de junho de 2014 no município de Tlatlaya, localizado na região sudoeste do Estado de México na divisa com o Estado de Guerrero, a Secretaria de Defensa Nacional - SEDENA reporta mais um confronto entre militares e supostos criminosos que deixaria um saldo de 22 pessoas abatidas de entre 16 e 24 anos de idade. Até esse momento todo estava dentro dos padrões de "normalidade" do combate armado contra os cartéis na região que involucra também aos Estados de Guerrero e Michoacán, um caldeirão de pequenos cartéis e braços armados produto da desarticulação da Familia Michoacana e dos Caballeros Templarios.

Pouco tempo depois, no dia 8 de julho, Mark Stevenson ${ }^{148}$, jornalista da Associated Press - AP, publica uma nota titulada "México: Balaceras del ejército crean sospechas" 149 no qual declara que a realidade do que aconteceu em Tlatlaya poderia ser muito diferente da versão oficial que a SEDENA deu já que considerou estranho o padrão de tiroteios semelhantes nos quais os militares não sofriam baixas enquanto todos os supostos criminosos eram abatidos ${ }^{150}$. Em paralelo, ressalta a estranha configuração dos furos de bala nas paredes devido à falta dos mesmos (apenas seis), embora tenha sido reportado um "tiroteio intenso" com armas automáticas disparadas desde longe, o qual afirma o autor, teria deixado muitos furos de balas perdidas $^{151}$. Aponta também o fato dos 22 abatidos terem sido encontrados mortos perto das

\footnotetext{
${ }^{148}$ Mark Stevenson - The Big Story - Associated Press - http://bigstory.ap.org/content/mark-stevenson

${ }^{149}$ México: Balaceras del ejército crean sospechas - Mark STEVENSON em La Hora, publicado em 12 de julho de 2014, disponível em: http://lahora.gt/hemeroteca-lh/mexico-balaceras-del-ejercito-crean-sospechas/ - acessado em abril de 2016

150 "Ha habido tantos incidentes de este tenor que grupos defensores de los derechos humanos y analistas han empezado a dudar de las versiones de los militares (...) 'Levanta sospechas el hecho de que hay 22 muertos por un lado y un herido por el otro"' Ídem.

151 "Aunque se informó que hubo un tiroteo intenso, solo seis andanadas parecen haber hecho impacto en la fachada (...) tampoco habia indicios de un tiroteo intenso dentro del edificio, pocos orificios de bala y ningún casquillo". İdem.
} 
paredes e furos de bala com sangue ao redor dando a impressão de que os abatidos teriam estado parados de frente às mesmas ${ }^{152}$.

No dia 19 de setembro de 2014, a revista Esquire ${ }^{153}$ publica uma reportagem na qual uma testemunha identificada como "Julia" oferece a sua versão do acontecido em Tlatlaya, versão na qual afirma que foram os militares os primeiros em abrirem fogo e foi apenas uma pessoa que morreu durante o tiroteio, os 21 restantes se renderam.

"Ellos (los soldados) decían que se rindieran y los muchachos decían que les perdonaran la vida. Entonces (los soldados) dijeron '¿no que muy machitos, hijos de su puta madre? ¿no que muy machitos?’. Así les decían los militares cuando ellos salieron (de la bodega). Todos salieron. Se rindieron, definitivamente se rindieron (...) Entonces les preguntaban cómo se llamaban y los herían, no los mataban. Yo decía que no lo hicieran, que no lo hicieran, y ellos decían que 'esos perros no merecen vivir'. (...) Luego los paraban así en hilera y los mataban (...) Estaba un lamento muy grande en la bodega, se escuchaban los quejidos" ${ }^{\prime 54}$.

A testemunha afirma que, enquanto durante o tiroteio inicial houveram duas pessoas feridas (uma mulher e um homem), o relatório da SEDENA informa que todos os supostos criminosos morreram durante a troca de tiros e documentação da perícia da Procuraduría General de Justicia del Estado de México - PGJEM afirma que nunca houveram disparos a queima-roupa senão que todos foram proporcionais ao ataque dos criminosos e não teve execuções ${ }^{155}$. $\mathrm{O}$ anterior contrasta com a declaração da testemunha ao afirmar que os dois feridos do tiroteio inicial foram executados a queima-roupa pelos militares, como reafirmado por um médico forense posteriormente ${ }^{156}$.

\footnotetext{
152 "[...] donde se habian hallado los cadáveres, la mayoría cerca de las paredes (...) Uno o dos grupos de agujeros de bala rodeados de una masa de manchas de sangre, lo que daba la impresión de que las personas en el interior estaban de pie frente a la pared y fueron alcanzadas por uno o dos disparos a la altura del pecho". Ídem.

${ }^{153}$ Exclusiva: Testigo revela ejecuciones en el Estado de México - Pablo FERRI TÓRTOLA em Revista Esquire Latinoamérica, sem data de publicação, disponível em: http://www.esquirelat.com/reportajes/14/09/17/esxclusivaesquire-Testigo-revela-ejecuciones-ejercito/ - acessado em abril de 2016.

154 Ídem

155 "El 15 de julio, la Procuraduría General de Justicia del Estado de México emitió un comunicado en el que afirmaba lo siguiente: "No existieron disparos a corta distancia; el intercambio de disparos fue proporcional; de acuerdo a la trayectoria de los proyectiles y la posición en que fueron hallados los cuerpos, (no existe) indicio alguno sobre una posible ejecución". ídem

156 "Cuando la hirieron en la pierna, continua 'Julia', Erika cayó boca abajo. La testigo dice que trato de ayudarla, pero los militares se lo impidieron. En vez de eso la voltearon y le dispararon en el pecho, según 'Julia', luego se pusieron unos guantes y la dejaron boca abajo, como estaba antes de rematarla (...) El certificado de defunción de Erika (...) indica que el motivo de la muerte fue 'impacto de bala en la cavidad torácica' (...) Uno de los médicos del Servicio Médico Forense (SEMEFO) de Toluca (...) dijo a Esquire que la bala perforó el corazón y un pulmón de Erika y que fue un 'tiro de gracia”' Ídem.
} 
A pressão tanto da AP como da Revista Esquire conseguiu evitar que o caso de Tlatlaya fosse arquivado como um confronto entre militares e criminosos a mais apesar dos esforços da SEDENA e da PGJEM de evitar que se indagasse o acontecido. O então Procurador da República, Jesús Murillo Karam, aliado do governo de Peña Nieto e quem terá um papel fundamental no caso Ayotzinapa, decide abrir uma investigação para indagar nas supostas irregularidades no agir das forças militares reconhecendo que, por momentos, os soldados atiraram sem justificativa alguma ${ }^{157}$. Enquanto Eruviel Ávila, governador do Estado de México, aliado próximo de Peña Nieto e principal favorito para sucedê-lo na presidência, evita dar declarações após ter afirmado que os soldados agiram legitimamente. Posteriormente, a Comisión Nacional de Derechos Humanos - CNDH emite um relatório (51/2014) ${ }^{158}$ após a investigação feita no qual consta que os militares executaram a pelo menos 15 pessoas das quais duas eram menores de idade e todos se encontravam desarmados, além de apontar que os soldados alteraram a cena do crime para ocultar as execuções. ${ }^{159}$

Em este primeiro caso apresentado, o qual foi escolhido pela difusão que teve na imprensa e na mídia mexicana, porém sabendo que não é o único caso do tipo, nos encontramos em primeiro lugar o perigo de outorgar labores policiais ás forças armadas no grande erro de Felipe Calderón ao começar o conflito armado e, em segundo lugar, a cumplicidade da SEDENA com a PGJEM e o governo de Eruviel Ávila para silenciar um caso de execução extrajudicial por parte do Exército Mexicano. Por um lado, é sintomático observar o agir do governador, principal possível candidato do PRI para suceder a Peña Nieto na presidência, ao tentar silenciar crimes

\footnotetext{
157 "Sin embargo, al cesar los disparos, ingresaron a la bodega tres de los elemento militares, uno se quedó afuera porque estaba herido, el Teniente porque lo estaba asistiendo, el chofer, porque él lo era, y los otros tres entraron realizaron una secuencia nueva de disparos que no tiene justificación alguna" - Fragmento da declaração de Jesús Murillo Karam - Tlatlaya: Cronológia básica, del 30 de junio al 2 de octubre - Redacción Aristegui Noticias, publicado em 22 de outubro de 2014 - disponível em: http://aristeguinoticias.com/2210/mexico/cronologia-delcaso-tlatlaya-desde-el-30-de-junio-al-21-de-octubre/ - acessado em abril de 2016 - (Grifo nosso).

${ }^{158}$ Recomendación No. 51/2014 - Sobre los hechos ocurridos el 30 de junio de 2014 en Cuadrilla Nueva, comunidad San Pedro Limón, Municipio de Tlatlaya, Estado de México - Disponível online em formato PDF no site da CNDH - http://www.cndh.org.mx/sites/all/doc/Recomendaciones/2014/Rec_2014_051.pdf - publicado em 21 de outubro de 2014, acessado em maio de 2014.

159 "1 de julio de 2014: El gobernador mexiquense, Eruviel Ávila reconoció la labor del ejército mexicano y aseguro que "en su legítima defensa abatió a los delincuentes" (...) 1 de octubre 2014: El gobernador del Estado de México, Eruviel Avila, solicitó a los reporteros ya no cuestionarle sobre el caso Tlatlaya (...) 21 de octubre: Casi cuatro meses después, la CNDH emitió un informe (...) La investigación señala que 8 elementos de la SEDENA ejecutaron a 15 de las 22 personas. Dos eran menores de edad y todos se habían rendido y estaban desarmados (...) La escena de los hechos fue manipulada por los soldados involucrados para hacer parecer que todos murieron durante el enfrentamiento". Ídem.
} 
contra a humanidade no seu estado se observarmos em contraste a crise de feminicídios no Estado de México durante a administração de Eruviel Ávila ${ }^{160}$.

Em paralelo, o titular da SEDENA, o general Salvador Cienfuegos, mantem uma postura despótica ao se negar a reconhecer os crimes dos soldados sob o seu comando e, além do mais, constrói um muro de impunidade e bloqueia qualquer tentativa civil de investigar os casos nos quais elementos militares têm sido envolvidos ${ }^{161}$, situação que se tornará ainda mais evidente no sumiço dos 43 estudantes de Ayotzinapa.

Porém, os problemas mais alarmantes que o caso Tlatlaya trouxe à discussão são: 1) a tortura e execução como método de ação comum do Exército Mexicano; e 2) a cadeia de comando que se articula desde o soldado raso até a Presidência da República.

No primeiro ponto encontramos às forças armadas agindo com a liberdade e impunidade que um Estado de exceção de facto outorga. Não é possível esperar que militares treinados para a guerra sejam capazes de agir em labores de cumprimento da lei e prevenção do delito em um contexto de vazio legal que lhes garante a impunidade total e, pior ainda, em um contexto no qual qualquer coisa está legitimada desde que seja feita em prol do combate ao narcotráfico. A questão em discussão não é se as vítimas eram ou não eram traficantes, senão que o Estado e o seu braço armado não respeitam o devido processo nem as leis que constituem ao Estado de direito e legitimam execuções sumarias por serem “cães que não merecem viver". A pergunta é a mesma que tem sido feita desde o começo da presente dissertação: quem decide quem é um “cão que não merece viver”? A resposta, neste caso, é simples: quem tiver o poder de fogo e a articulação institucional ao seu lado.

O perigo de legitimar e normalizar práticas como execuções sumarias e tortura é enorme para a população civil, mais ainda quando as instituições (tais como a PGJEM) tentam silenciar os acontecimentos e abandonam à cidadania nas mãos de militares, neste caso, que têm licença

\footnotetext{
${ }^{160}$ Embora as cifras sobre feminicidios não sejam claras nem confiáveis, o portal de jornalismo de investigação VICE reporta, segundo comparação de cifras de distintos organismos (INEGI, Sistema Nacional de Seguridad Publica, Banco Nacional de Datos e Información sobre Casos de Violencia contra las Mujeres) um total de 12.950 casos de agressão contra mulheres no Estado de México desde 2012 - Asesinadas en el Estado de México, una silenciosa epidemia - Rafael CASTILLO em Vice, publicado em 23 de junho de 2015, disponível em: http://www.vice.com/es_mx/read/asesinadas-en-el-estado-de-mexico-una-silenciosa-epidemia - acessado em abril de 2016.

161 "Las comisiones especiales creada en la Cámara de Diputados han sido desdeñadas, el IFAI apenas ha logrado alguna información descontextualizada y hasta ha sido cuestionado por la SEDENA, mientras que la PGR ha tenido que integrar sus averiguaciones con lo que el Ejército ha querido entregar" - SEDENA oculta información sobre Tlatlaya y Ayotzinapa - Jorge CARARASCO ARAIZAGA, em Proceso, publicado em 28 de março de 2015, disponível em: http://www.proceso.com.mx/399681/399681-sedena-oculta-informacion-sobre-tlatlaya-yayotzinapa - acessado em abril de 2016.
} 
para assassinar criminosos sem perguntar nem seguir o devido protocolo e processo e, ainda mais perigoso é que a etiqueta de "traficante" seja uma escusa para virar um ente exterminável sendo que o poder de outorgar e classificar arbitrariamente ás pessoas dentro de essa categoria é monopolizada por um soldado treinado para matar, protegido e legitimado pela SEDENA ${ }^{162}$ e pelas instituições de acesso à justiça. O poder de definir ao Outro-exterminável é imenso.

O Batalhão 102 de Infantaria do Exército Mexicano, ao qual pertencem os soldados involucrados na execução sumaria de Tlatlaya, tem antecedentes de outras execuções sumarias como apontam reportagens especiais da Revista Proceso, o portal jornalístico Aristegui Noticias e o jornal El Financiero ${ }^{163}$. Inaugurado em 2010 pelo presidente Peña Nieto como parte da guerra contra o narcotráfico, ou eufemisticamente, "Operativo Seguridad Mexiquense", o batalhão tem pelo menos uma dúzia de elementos acusados de homicídio por execução extrajudicial de supostos integrantes de cartéis como coloca Proceso. Por sua vez, El Financiero denuncia a execução de quatro funcionários públicos do povoado de Arcelia no estado de Guerrero por parte de militares que os "confundiram" com traficantes resultando 4 soldados presos e, por outro lado, Aristegui Noticias reporta que o batalhão tem acusações de corrupção ao receber propinas do cartel da Familia Michoacana.

O descontrole das forças armadas e a proteção que recebem dos altos mandos da SEDENA foram evidenciados com o vazamento de um vídeo ${ }^{164}$ no qual dois militares e uma mulher da Policía Federal, portando os uniformes correspondentes e com armas de alto calibre, torturam a uma mulher civil de 22 anos de idade de nome Elvira Santibáñez. A tortura é com a intenção de obter informação sobre a localização de uma pessoa de nome María. No vídeo, a vítima encontra-se de joelhos chorando enquanto uma mulher militar a interroga e a agente da PF a

\footnotetext{
162 "En menos de cuatro meses (el general Salvador Cienfuegos) dio tres larga entrevistas de prensa para deslindar a esa fuerza de las ejecuciones sumarias en Tlatlaya (...) Su mensaje ha sido claro: 'No permitiré que nos traten como criminales' (...) 'No me queda claro ni puedo permitir que interroguen a mis soldados, que no cometieron hata ahora ningún delito' (...) 'Yo soy de la opinión que, si vamos a utilizar a las Fuerzas Armadas, las utilicemos para poner orden, no para ver si ponemos orden'," - El general Cienfuegos, juez y parte en los casos Tlatlaya y Ayotzinapa - Jorge CARRASCO ARAIZAGA em Proceso, publicado em 13 de outubro de 2015, disponível em: http://www.proceso.com.mx/418002/el-general-cienfuegos-juez-y-parte-en-los-casos-tlatlaya-yayotzinapa - acessado em abril de 2016.

163 Proceso: Batallón 102: una historia criminal - Jorge CARRASCO ARAIZAGA (http://www.proceso.com.mx/383818/batallon-102-un-historial-criminal )publicado em 4 de outubro de 2014; Aristegui Noticias: Batallón 102, en Edomex, ya ha sido involucrado en "hechos de sangre" - Redacción ; (http://aristeguinoticias.com/0110/mexico/el-batallon-102-en-el-edomex-ya-ha-sido-involucrado-en-hechos-desangre-periodista/) publicado em 1 de outubro de 2014; El Financiero: Batallón de caso Tlatlaya tiene un historial marcado por incidentes - AP (http://www.elfinanciero.com.mx/sociedad/batallon-de-caso-tlatlaya-tiene-unhistorial-marcado-por-incidentes.html ) publicado em 27 de setembro de 2014; acessados em abril de 2016.

${ }^{164}$ Vídeo disponível em: http://www.hoyestado.com/2016/04/video-aclara-sedena-caso-de-tortura-en-guerrero/ acessado em abril de 2016
} 
sufoca com uma sacola plástica um par de vezes. De novo, é possível apreciar o agir das forças armadas e de segurança em total impunidade e liberdade pelo fato de -suspeitar- que a vítima pertencia a algum cartel do narcotráfico ${ }^{165}$. O Estado de direito foi sufocado e destruído pelo Estado de exceção que Felipe Calderón inauguro para deflagrar a sua guerra e, independentemente da até agora não provada culpabilidade ou inocência da vítima, a tortura passou de ser um crime contra a humanidade a ser um método de interrogação de prováveis suspeitos por parte da Policía Federal e do Exército Mexicano.

A resposta da SEDENA ante tão contundente evidência foi simples e previsível. O general Cienfuegos, em um mea culpa mais forçado do que sincero, ofereceu desculpas publicamente ${ }^{166}$ pelo agir improprio dos elementos sob o seu comando. Porém, diante da virulência que a prática da tortura adquiriu no interior do Exército Mexicano, a desculpa de Cienfuegos parece, como afirma José Gil Olmos ${ }^{167}$ uma desculpa “[...] anticipada ante los miles de fuegos que podrían suscitarse en el país y que desde fuera se ven con preocupación porque podrían propalarse en tempos de crisis".

Porém, o medo de Gil Olmos não carece de fundamentos e, infelizmente, não é uma advertência mais do que é mesmo uma lembrança. A tortura está estabelecida como prática comum no Exército Mexicano em tempos de guerra contra os cartéis, uma herança direta da época dura do regime do PRI ${ }^{168}$ na década de 1960, 1970 e 1980. Essa herança continua até hoje como os números da própria justiça militar o demonstram com 229 casos de tortura acompanhados de 102 desaparições forçadas registrados em $8 \operatorname{anos}^{169}$ desde a deflagração da guerra contra os

165 "Repulsivo y estremecedor, el video se difundio viralmente en las redes sociales. Elvira Santibáñez, de 22 años fue torturada el 4 de febrero de 2015 en Ajuchitlán del Progreso, Guerrero, por presuntamente pertenecer a la Familia Michoacana. Actualmente se encuentra presa en el penal federal de Tepic, Nayarit, por el delito de portación de arma de fuego" - Barbarie evidente e intolerable - Hector TAJONAR em Proceso, publicado em 27 de abril de 2016, disponível em: http://www.proceso.com.mx/438677/barbarie-evidente-e-intolerable - acessado em abril de 2016.

166 "Los he reunido este día porque es necesario expresar púbicamente nuestra indignación por los hechos lamentables que sucedieron hace casi 14 meses (...) malos integrantes de nuestra institución, empañan la actuación honorable de miles de mujeres y hombres en uniforme militar" Ídem.

${ }^{167}$ El mensaje de Cienfuegos, José GIL OLMOS em Proceso, publicado em 20 de abril de 2016, disponível em: http://www.proceso.com.mx/437761/el-mensaje-de-cienfuegos - acessado em abril de 2016.

168 "La tortura ha sido inveterada práctica de la autoridad civil y de la militar. Lo fue en las represiones de los años cincuenta, sesenta, setenta y siempre vuelve a asomar. Fernando Gutiérrez Barrios, jefe de la seguridad del Estado, era el mayor organizador de tortura en el país, pero en Tlaxcoaque, sede de la policía capitalina, había cámaras de tortura contra detenidos comunes y politicos por igual (...) Jefes y oficiales en el Ejército también hacían lo suyo, solos o en compañía de los brutales agentes de la entonces Dirección Federal de Seguridad (DFS), como ocurre ahora con las 'operaciones mixtas"' - Tortura: ¿peores escenarios? - Pablo GÓMEZ em Proceso, publicado em 22 de abril de 2016, disponível em: http://www.proceso.com.mx/438064/tortura-peores-escenarios - acessado em abril de 2016.

169 "La fuente de estas cifras que ofuscan no es una contestataria organización no gubernamental ni un radical organismo mundial que defiende los derechos humanos, sino la propia justicia militar de México: Entre 2007 y 2015 se registraron 229 casos de tortura cometidos por militares y 102 desapariciones forzadas" - La tortura 
cartéis; as 4.055 denúncias de tortura diante da Procuraduría General de la República - PGR nos mesmos 8 anos das quais 1.273 involucram a militares ${ }^{170}$, segundo o jornalista Pablo Gómez da Revista Proceso; ou a tortura que sofreram três sobreviventes da execução sumaria de Tlatlaya por parte de funcionários públicos do Estado de México denunciada no apartado 118 do relatório e recomendação número 51/2014 ${ }^{171}$ da CNDH.

Por outro lado, o agir dos elementos castrenses segue uma cadeia de comando que chega até o mesmo Presidente da República quem também é o Comandante Supremo das Forças Armadas Mexicanas e, portanto, responsável do agir do Exército, da Força Aérea e da Marinha. Uma investigação do Centro de Derechos Humanos Miguel Agustín Pro Juárez - PRODH publicada no informe titulado Tlatlaya a un año: La orden fue abatir $(2015)^{172}$, revela a existência de um documento classificado como confidencial que faz parte da Orden General de Operaciones de la Base de Operaciones "San Antonio del Rosario" que, por sua vez, está fundamentado no Programa Sectorial de Defensa Nacional 2013-2018 ${ }^{173}$ que faz parte da Operación Dragón ${ }^{174}$. Estes documentos reafirmam a securitização do combate ao narcotráfico e a via bélica a seguir, em conjunto com a modernização das forças armadas contemplado para a duração do mandato de Enrique Peña Nieto (2012-2018).

\footnotetext{
"La Seguridad Nacional es una condición esencial para preservar la integridad, la estabilidad y la permanencia del Estado Mexicano, cuyas vertientes esenciales son la Seguridad Interior y la Defensa Exterior de la Federación; que son responsabilidad ineludible de todos los entes del Estado, con una participación importante de las Fuerzas Armadas" - Programa Sectorial de Defensa Nacional 2013-2018, pág. 9.
}

As referências à Orden General de Operaciones aqui expressadas são provenientes do informe acima referido do Centro PRODH devido à confidencialidade do documento original. No

militar, casi un deporte - Álvaro DELGADO em Proceso, publicado em 18 de abril de 2016, disponível em: http://www.proceso.com.mx/437583/la-tortura-militar-casi-deporte - acessado em abril de 2016.

170 Ídem.

171 "118. Además de las violaciones a derechos humanos cometidas por personal militar que participó en los hechos, este Organismo Nacional logró acreditar la tortura y agresiones sexuales cometidas por parte de personal adscrito a la Procuraduría General de Justicia del Estado de México, en agravio de V24 y V25, y los tratos inhumanos en agravio de V23, mujeres que estuvieron presentes en la bodega durante el momento de los hechos, así como diversas irregularidades durante la integración de la carpeta de investigación 1; hechos sobre los cuales se hará el pronunciamiento respectivo en la presente recomendación” Recomendación 51/2014 de la CNDH, apartado 118. Grifo nosso. Op.Cit.

172 Publicado em 2015 pelo Centro PRODH; disponível online em formato PDF através de: http://www.centroprodh.org.mx/index.php?option=com_docman\&Itemid=28\&lang=es

173 Publicado em 2013 pela SEDENA; disponível em online em formato PDF através do site da SEDENA http://www.sedena.gob.mx/archivos/psdn_2013_2018.pdf - acessado em maio de 2016.

${ }^{174}$ A constituição e os detalhes da Operación Dragón são confidenciais e não existe acesso à documentação. 
documento mencionado se expressam ordens provenientes do "alto mando" das forças armadas, o qual se refere ao General Salvador Cienfuegos e ao Presidente Enrique Peña Nieto. Ditas ordens, segundo o informe do Centro PRODH, incentivam e obrigam, pela obediência estrita dos elementos castrenses, à uma linha de comportamento e de ação altamente hostil e agressiva $^{175}$ seguindo uma lógica clandestina de operação e usando o eufemismo - abater $^{176}$ como primeira forma de ação ao momento de confrontar supostos criminosos ${ }^{177}$, situação que não é contemplada na legislação que governa às forças armadas ${ }^{178}$ como é explicitado na Directiva que Regula el Uso Legitimo de la Fuerza por Parte del Personal del Ejército y Fuerza Aerea Mexicanos(... $)^{179}$ publicado no Diario Oficial de la Federación em 2012. O documento estabelece o procedimento que os militares deverão seguir na aplicação da lei e os níveis de uso da força que se usarão diante do crime organizado. Não está demais dizer que é claro que o termo abatir nunca é utilizado no documento e muito menos se incentiva ao uso letal da força como primeira forma de ação.

A discordância entre o discurso explícito e o discurso oculto do Estado Mexicano e das Forças Armadas é apenas possível se contextualizado na situação de exceção que o país atravessa. Por um lado, os estatutos governantes das Forças Armadas estabelecem o respeito aos direitos humanos na primeira ordem de importância e o uso legitimo da força de maneira proporcional e visando preservar a integridade e a vida humana na medida possível; por outro lado os documentos não oficiais incentivam o extermínio noturno como primeira forma de ação. Essa discordância encontra-se essencialmente fora de qualquer estado de direito e, como foi mencionado, é apenas possível a sua existência dentro de uma bolha de exceção da legalidade que permite a convivência de discordâncias como a mencionada. Além do mais, o vazio legal e ambiguidade com relação aos termos usados como "abatir" ou a definição mesma de

\footnotetext{
175 "Pero sin duda lo más preocupante es que la Orden de Relevo alienta a la violación de los derechos humanos. En la disposición V, la Orden de Relevo mandata que "las acciones para reducir la violencia se planearán y ejecutarán en horas de oscuridad, sobre objetivos específicos" Informe Tlatlaya a un año: La orden fue abatir do Centro PRODH, pág. 19.

${ }^{176} \mathrm{O}$ verbo abatir em epanhol, segundo o Diccionario de la lengua epañola da Real Academia Española, é um verbo transitivo que significa na sua primeira acepção: “derrubar alguma coisa, derrocá-la” e na sua quarta acepção: "fazer cair sem vida a uma pessoa ou animal”; no geral, a palavra faz referência à queda.

177 "Las tropas deberán operar en la noche en forma masiva y en el día reducir la actividad a fin de abatir delincuentes en horas de oscuridad, ya que el mayor número de delitos se comete en este horario" Ídem.

178 "Máxime considerando que la Directiva que Regula el Uso Legítimo de la Fuerza por parte del Personal del Ejército y Fuerza Aérea Mexicanos, en ningún momento faculta a los castrenses para 'abatir' delincuentes en horas de oscuridad. De hecho, ninguna ley o disposición reglamentaria lo hace.” Ídem.

${ }^{179}$ Directiva que regula el uso legítimo de la fuerza por parte del personal del ejército y fuerza aérea mexicanos, en cumplimiento del ejercicio de sus funciones, en apoyo a las autoridades civiles en la aplicación de la ley federal de armas de fuego y explosivos. Disponível online em formato PDF através do site do Diario Oficial de la Federación: http://www.dof.gob.mx/nota_detalle.php?codigo=5244755\&fecha=23/04/2012 - Diario Oficial de la Federación, publicado em 23 de abril de 2012, acessado em maio de 2016.
} 
"delinquente" permite um agir livre dos elementos castrenses que são dotados da faculdade de abrir fogo indiscriminadamente desde que seja dirigido contra "criminosos". O mesmo vazio legal os faculta para definir o que seria um "criminoso" e os legitima com ordens como as expostas na Orden General de Operaciones.

Outro aspecto preocupante de esta lógica de ação é a impunidade que decorre da exceção da legalidade. Com a legalidade excluída da vida institucional do Estado mexicano e a legitimidade que se auto outorga com o pretexto do combate ao narcotráfico e a securitização da vida pública, os agentes do Estado não são sujeitos ao devido processo e, no caso de Tlatlaya, é evidenciado com a absolvição na ordem civil e militar dos soldados involucrados na execução sumaria por “falta de evidências" diante do Ministério Público Federal através do Juzgado Decimocuarto de Distrito de Procesos Penales Federales na ordem civil e do Juzgado Sexto Militar da SEDENA. Dos sete militares acusados, todos foram absolvidos na ordem civil, seis foram absolvidos na ordem militar e apenas um foi condenado a um ano de prisão por delito de desobediência ${ }^{180}$. O organismo Amnistia Internacional, em colaboração com outros organismos de defesa dos direitos humanos, afirma, mediante um comunicado ${ }^{181}$, a opacidade e serie de omissões da PGR que se negou a investigar e questionar aos altos mandos militares responsáveis da criação da Orden General de Operaciones, documento considerado como responsável da execução sumaria de Tlatlaya, embora a PGR ainda não tenha arquivado a solicitude de procedimento e investigação da cadeia de comando que deu a ordem de - abatir delinquentes na escuridão ${ }^{182}$-, cadeia de comando que aponta para o presidente Enrique Peña Nieto, Comandante Supremo das Forças Armadas Mexicanas.

\footnotetext{
${ }^{180}$ Caso Tlatlaya: "Se encamina a quedar impune" - Redacción Aristegui Noticias, publicado em 30 de março de 2016, disponível em: http://aristeguinoticias.com/3003/mexico/solo-un-militar-condenado-por-matanza-entlatlaya-todos-ya-estan-libres/; Libres los cuatro militares exonerados por caso Tlatlaya - Arturo RODRÍGUEZ GARCÍA em Proceso, publicado em outubro de 2015, disponível em: http://www.proceso.com.mx/418242/libreslos-cuatro-militares-exonerados-por-caso-tlatlaya - acessados em maio de 2016.

${ }^{181}$ Se consolida la impunidad en el caso Tlatlaya: Fuero militar absuelve a soldados involucrados y PGR omite investigar la orden de abatir - publicado em 29 de março de 2016, disponível online através de Sribd: https://es.scribd.com/doc/306389577/160329-Se-Consolida-Impunidad-Tlatlaya\#fullscreen - acessado em maio de 2016.

182 "[...] la coadyuvancia solicitó que los mandos militares a cargo de emitir y supervisar dicha orden fueran citados a declarar a fin de deslindar responsabilidades por cadena de mando. Sin embargo, tras nueve meses la PGR no ha citado a ningún mando militar, eludiendo así sus deberes y negando un ejercicio elemental de rendición de cuentas (...) la PGR aún mantiene abierta la averiguación previa donde se ha solicitado investigar la cadena de mando respecto a la orden de abatir (...) los organismos de derechos humanos nuevamente advertimos sobre el riesgo de que en este caso emblemático termine imponiéndose la impunidad" Ídem.
} 


\section{San Fernando - A territorialidade do narcotráfico}

O segundo caso escolhido é o dos Massacres de San Fernando ocorridos entre 2010 e 2011 no município do mesmo nome no estado de Tamaulipas, no nordeste da República Mexicana. O primeiro massacre, por falar seguindo a ordem em que os acontecimentos foram descobertos, ocorreu em agosto de 2010 e deixou um saldo de 72 pessoas executadas, alguns mexicanos, mas a maioria migrantes da América Central e do Sul em rota para os Estados Unidos, sendo 14 mexicanos, 24 hondurenhos, 14 salvadorenhos, 13 guatemaltecos, 5 equatorianos, 3 brasileiros e um indiano $^{183}$. Os massacres posteriores foram apenas revelados após a descoberta de covas clandestinas nas quais somam aproximadamente 196 o número de cadáveres encontrados ${ }^{184}$.

No primeiro massacre, as vítimas, segundo os relatos de duas pessoas que sobreviveram, foram baleados e depois executados com golpes de misericórdia. As vítimas seguiam a rota mais comum de trânsito através de território mexicano desde a fronteira sul com a Guatemala até a fronteira norte com os Estados Unidos ${ }^{185}$. É um trajeto que se aproveita de uma rede ferroviária que vai desde Chiapas ou Tabasco, estados fronteiriços do Sul, para entrar no estado de Veracruz (Golfo do México) onde se divide em uma rota que a) se dirige pelo centro do país, passando pela Cidade do México para dirigir-se ao litoral Pacífico e chegar até a fronteira noroeste com os Estados Unidos na região de Tijuana e Nogales (paralelos a Califórnia e Arizona); e outra rota que b), continua através do estado de Veracruz até chegar a Tamaulipas e a fronteira nordeste com os Estados Unidos na região do sudeste do Texas. Sintomaticamente, os trens que percorrem essa rota ferroviária são apelidados como "La Bestia"186.

O responsável do massacre: o cartel de Los Zetas. O motivo do ataque direto contra os migrantes parece ter sido produto da confrontação entre os Zetas e o Cartel del Golfo, lembrando que os Zetas, antigos soldados de elite do Exército Mexicano, desertaram para trabalhar como o braço

\footnotetext{
${ }^{183}$ Así ocurrió la peor matanza de inmigrantes en México - Juan Carlos PÉREZ SALAZAR em BBC Mundo, $\begin{array}{lllllll}\text { publicado em } & 21 & \text { de } & \text { agosto } & \text { de } & 2015, & \text { disponível }\end{array}$ http://www.bbc.com/mundo/noticias/2014/08/140828 mexico_matanza_inmigrantes_centroamericanos anivers ario_jcps - acessado em maio de 2016.

${ }_{184}$ Aumenta a 193 los muertos por matanza en San Fernando, Tamaulipas: PGR - Autor Invitado em Zócalo Saltillo, publicado em 7 de junho de 2011, disponível em: http://www.zocalo.com.mx/seccion/articulo/aumentaa-193-los-muertos-por-matanza-en-san-fernando-tamaulipas-pgr - acessado em maio de 2016.

185 "Los vendaron, los obligaron a apoyarse contra un muro y luego los balearon. Después les dieron tiros de gracia (...) Solo dos personas se salvaron: una que no ha ido identificada y un joven ecuatoriano que es quien ha permitido armar el rompecabezas de lo que ocurrió (...) habian pasado lo que consideraban más peligroso, que era utilizar a La Bestia, una red de trenes que va desde Chiapas, en el sur de México, hasta la frontera con Estados Unidos" Así ocurrió la peor matanza de inmigrantes en México. Juan Carlos PÉREZ SALAZAR. Op.Cit.

${ }^{186}$ Fonte: http://newspagedesigner.org/photo/mapa-la-bestia?context=user - acessado em maio de 2016.
} 
armado do Cartel del Golfo. Posteriormente se separariam e começariam a agir de maneira independente e em direto confronto com o cartel pelo controle de territórios e rotas de tráfico. Segundo o reportado pelo portal BBC Mundo e o jornal salvadorenho El Faro, o Cartel del Golfo extorquia aos coyotes ${ }^{187}$ para permitir o passo de migrantes pelos territórios controlados e esse método foi retomado pelos Zetas após a sua separação. A hipótese aponta a que o massacre foi uma advertência do que poderia acontecer devido à falta de pago de algum coyote.

Outra versão aponta a um dos métodos que os Zetas usariam para recrutar pessoas. Segundo a testemunha de um dos sobreviventes, os migrantes a bordo de um ônibus foram interceptados por um comando dos Zetas e levados para dentro de um galpão no qual os 58 homens e 14 mulheres (menores de idade incluídos) foram fuzilados e depois executados com golpes de misericórdia ${ }^{188}$. O sobrevivente fingiu estar morto e, a pesar de ter levado um tiro no pescoço, conseguiu escapar e pedir ajuda de elementos da Marinha mexicana ${ }^{189}$. No seu depoimento assegura que os traficantes ofereceram trabalho como sicários com um salário de USD \$2000.00 mensais. Após terem rejeitado o oferecimento de emprego, os migrantes teriam sido fuzilados ${ }^{190}$.

Esta última versão parece ser consistente pelos relatos dos massacres que continuariam acontecendo na região durante os próximos meses. O modus operandi de interceptar ônibus de passageiros no meio da noite e levá-los a locais isolados se repetiria em posteriores relatos de sobreviventes, como é o caso do massacre ocorrido no dia 25 de março de 2011.

A testemunha anônima narra que, no clima de terror que se vivia no município pela presença ostensiva dos Zetas, as atividades cessavam após a pôr do sol. O ônibus em questão dirigia-se

\footnotetext{
${ }^{187} \mathrm{O}$ coyote é a pessoa que se dedica a levar através de território mexicano e internar em território estadunidense aos migrantes tanto mexicanos como da América central e do Sul - Fonte: Diccionario de la Real Academia Española-RAE.

188 "Los 72 indocumentados asesinados en San Fernando, Tamaulipas, iban en un camión rumbo a Estados unidos cuando, entre el sábado y el domingo pasado, fueron interceptados por un convoy de Zetas (...) Uno a uno, los 58 hombres y 14 mujeres, entre ellos menores de edad, fueron colocados contra la pared dentro de una bodega del rancho. Luego se les obligó a quedarse con la cabeza agachada y fueron fusilados con ráfagas de armas de alto poder. Al final, los asesinos remataron con el tiro de gracia a cada una de sus víctimas". Masacre en San Fernando: Por negarse a ser sicarios los fusilaron - Redacción El Universal através de Vanguardia MX, publicado em 26 de agosto de 2010, disponível em: http://www.vanguardia.com.mx/masacreensanfernandopornegarseasersicarioslosfusilaron-540517.html acessado em maio de 2016.

189 "Entre los fusilados estaba un ciudadano de Ecuador, quien se hizo pasar por muerto (...) El tiro final le entró, al parecer, por un extremo del cuello y salió por la mandibula (...) Hasta el momento, lo que es un misterio, es como recorrió los casi 22 kilómetros que separan al sitio del punto donde hizo contacto con personal de la Armada de México al que pidió ayuda". Ídem.

190 "Narró que los maleantes les ofrecieron trabajo como sicarios, y que ganarían mil dólares a la quincena. Todos se resistieron y con el rechazo vino la masacre". Ídem.
} 
à cidade fronteiriça de Reynosa e contava com 15 passageiros. No meio do caminho são interceptados por um comando de homens armados com fuzis AR-15 que abordaram o ônibus, o qual foi levado por trilhas até chegar a uma zona aberta onde se encontravam 20 camionetes de luxo e outros 3 ônibus sequestrados ${ }^{191}$.

A partir de aqui é onde começa a narrativa do terror que aconteceu essa noite. O relato lembra do processo de seleção de presos em campos de concentração durante o regime nazista: os homens foram selecionados separando aos fracos, doentes ou idosos do grupo, os quais foram reunidos com outros homens das mesmas características. Os "fortes" foram encarados por uma personagem identificada apenas como Comandante $40^{192}$.

“'A ver cabrones, el que quiera vivir que lo diga de una vez', pero nadie contestó, todos miraban al suelo, ni siquiera podían levantar la mirada por el temor. Un joven como de unos 15 años se orinó de miedo en sus pantalones mientras visiblemente se veía que temblaba fuertemente como si tuviera frio y las lágrimas corrían por sus mejillas. El mentado Comandante 40 sacó su arma corta de la fornitura y sin titubear le pegó un tiro en la frente, el muchacho se desplomó de inmediato, mientras los otros hombres lo veían temblando aún más de miedo. ‘¿Quién más es maricón?’ Preguntó el Comandante.”’ 193.

A continuação os homens restantes seriam obrigados a lutarem entre eles com malhos, quem sobrevivesse seria novo integrante do cartel.

“Uno de los pasajeros se acercó llorando a él diciéndole: 'Por favor señor, yo no quiero hacer esto, le doy todo el dinero que traigo y mi casa pero déjenos ir', el Comandante 40 lo vio fijamente a los ojos, le quitó el mazo y le dijo: 'Está bien pinche maricón, vete' y tan pronto el hombre dio la vuelta le pegó con el mazo en la cabeza con una fuerza brutal, el hombre cayó al suelo bañado en sangre y 40 se puso como loco dándole golpes en la cabeza con el mazo como 20 veces hasta que quedó deshecha totalmente. 'Esto es lo que tienen

\footnotetext{
191 "Las calles de San Fernando se vacian a las 6 de la tarde (...) nadie sale de sus casas, todos se resguardan por el miedo a los Zetas. Solo se pueden ver algunas camionetas de lujo circulando por las calles, nadie se quiere topar con ellos (...) El autobús iba saliendo de la ciudad, el chofer miró a lo lejos unas camionetas atravesadas a mitad de la calle y unos hombres encapuchados empuñando sus AR-15, en ese instante supo que todo había acabado (...) Llegaron a una parte muy amplia y sin monte (...) ahi se encontraban 20 camionetas aproximadamente, de lujo, y también 3 autobuses (...)." - Testigo de masacre en San Fernando relata pesadilla, Redacción La Policiaca, publiado em 18 de abril de 2011, disponível em: http://www.lapoliciaca.com/notaroja/testigo-de-masacre-en-san-fernando-relata-pesadilla/ - acessado em maio de 2016.

192 "Bajaron aproximadamente a 8 hombres que iban desde los 15 hasta los 50 años. Los formaron abajo del autobús, y unos hombres se acercaron a ellos y empezaron a clasificarlos, sacaron a los que veían que estaban viejos o débiles, sacaron a dos ancianos y dos que parecían enfermos (...)." Ídem.

${ }^{193}$ Ídem.
} 
que hacer hijos de puta, usar los huevos, el que no quiera que me diga y yo le parto su madre', todos los hombres comenzaron a luchar entre sí."194

Por outro lado, as mulheres e crianças receberiam um trato ainda mais cruel. Os sicários subiram aos ônibus e selecionaram às mulheres que consideravam mais bonitas para serem estupradas posteriormente em um galpão, enquanto outros tiravam os filhos dos braços de outras mulheres ${ }^{195}$.

\footnotetext{
“A los niños los llevaron a otra parte, en donde había unos tanques con ácido, ahí los aventaban, se oían los gritos de dolor mientras se deshacían. Y los sicarios solo reían a carcajadas, uno de ellos les gritó a los demás: 'Ya va a estar el caldo"." 196
}

Finalmente, os motoristas foram obrigados a passar o ônibus por encima dos homens que foram separados do grupo por serem idosos ou doentes para posteriormente serem executados com um tiro na têmpora junto com as mulheres que ainda estavam dentro dos ônibus, os quais seriam queimados posteriormente ${ }^{197}$.

“El Comandante 40 reunió a todos los Zetas y les dijo: 'Ya estuvo bueno de diversión por esta noche cabrones, traigan a los ganadores' y trajeron a los que habían matado a su contra con el mazo y les dijo: 'Bienvenidos al grupo de Fuerzas Especiales Zeta, el otro ejército." "198

Se bem a reportagem procede de um jornal sensacionalista que normalmente se caracteriza pela teatralidade com a que descrevem à morte, pelo menos no México, os fatos acontecidos demonstram a crueldade e o prazer pela morte que tem se naturalizado no país além da liberdade que os cartéis possuem para organizar esses espetáculos de terror dentro de territórios que evidentemente são controlados por eles e, mais alarmante ainda, a possível infiltração de agentes dos cartéis a estrutura policial municipal.

\footnotetext{
194 Ídem.

195 '“...] bajaron a las muchachas que les parecian más guapas, mientras les gritaban 'Muévete puta', todas lloraban y gritaban al igual que los niños, uno de ellos dijo, 'A ver perras, denme a sus cachorros' (...) a las jóvenes que bajaron las llevaron a una casucha donde había más mujeres jóvenes (...) les arrancaron sus ropas y las comenzaron a violar. Dentro de esa casucha había aproximadamente 30 mujeres que estaban siendo violadas, otras más estaban despedazadas en el piso." Ídem.

196 Ídem.

197 “El hombre ordenó al chofer que encendiera la unidad (...) 'Pasa por arriba de ellos' le dijo el sicario al chofer (...) 'Que pases por arriba de ellos o te pongo ahi para que te lleve la chingada a ti también pendejo' (...) mientras conducía podía sentir como si pasara por topes, pero la diferencia es que aquí podía escuchar los gritos de dolor de las personas que estaban abajo (...) fue ahí cuando el sicario le pegó un tiro en la sien al chofer y empezó a dispararles a las mujeres abordo. Bajaron y le prendieron fuero al autobús. "Ídem.

198 Ídem.
} 
Em primeiro lugar é necessário ressaltar a territorialidade intrínseca ao funcionamento dos cartéis e dos seus braços armados entendendo ao mesmo tempo ao território como um instrumento para exercer o poder através da instrumentalização não absoluta da violência que, por sua vez, prolifera em um ambiente viciado no qual nem o Estado nem o narcotráfico podem exercer poder hegemônico ${ }^{199}$, ideia que deixa em dúvida a noção do poder como monopólio do Estado no território ${ }^{200}$. Quando falamos do controle de territórios que o narcotráfico assumiu em detrimento do Estado não é que estes territórios tenham sido extirpados da organização político-territorial do país para conformar Estados paralelos clandestinos e enquistados no território mexicano, senão que os usos que se dão a estes territórios são diversos e convivem entre eles, tanto quando são os cartéis agindo ou o aparelho estatal os quais ocupam os territórios. Este fenômeno, por sua vez, de certa forma permite quebrar com o paradigma dominante do poder do Estado e a limitação da concepção e do uso do território apenas na escala do território de um Estado-nação, permitindo entrever as territorialidades mais complexas do cotidiano (LOPES DE SOUZA: 1995).

O relatado na crônica do segundo massacre revela nos primeiros instantes o estado de terror que dominava na cidade pela presença ostensiva dos Zetas nas ruas em horários definidos, particularmente nas últimas horas da tarde, sendo a noite o horário de maior perigo percebido pelos habitantes, particularmente nas estradas onde os ônibus eram abordados e sequestrados por sicários. Nesse caso não seria possível falar de que a cidade seja uma área ocupada por certo tipo de pessoa que utiliza de certa maneira o território e a noite cede esse espaço para outro tipo de uso com outros atores (LOPES DE SOUZA: 1995) já que seria acreditar que essa opção existe, ou que existe mesmo algum resquício de opção. O poder de fogo do narcotráfico e o uso que lhe dão a essas armas contra a população e das forças de segurança locais é motivo e razão suficiente para saber que a noite as ruas e as estradas são dos Zetas e não do Estado. A relação de poder que se estabelece entre o cartel e a população civil é altamente coercitiva e está fundada no monopólio da violência que o Estado perdeu diante do poder bélico dos cartéis. Por sua vez, como foi mencionado, esses territórios são de certa maneira flexíveis e variáveis, isto é, não existe uma fronteira estabelecida no tempo e no espaço físico que delimite o ponto de começo

\footnotetext{
199 "No que diz respeito à violência, ela se distinguiria, segundo Hannah Arendt, por seu 'caráter instrumental' (...) o poder não carece de justificativas, já que seria inerente à existência de qualquer comunidade política, no entanto, demanda legitimidade (...) Por isso é que Hannah Arendt é categórica ao afirmar: '(...) politicamente falado, é insuficiente dizer não serem o poder e a violência a mesma coisa. O poder e a violência se opõem: onde um domina de forma absoluta, o outro está ausente"” (LOPES DE SOUZA: 1995, p. 80).

200 "[...] uma vez que o território é essencialmente um instrumento de exercício de poder: quem domina ou influencia quem nesse espaço, e como?" (Ibidem, 79).
} 
do controle do narcotráfico, da população civil ou do Exército e Marinha mexicana. Quando esses territórios se entrecruzam ou, por exemplo, quando um ônibus de passageiros se dirige de noite por uma estrada controlada pelo cartel, acontece o que foi narrado nas páginas anteriores $^{201}$.

Isto é um exemplo de territorialidades flexíveis espaço-temporais que não respondem a uma noção dura de território na qual unicamente o Estado exerce o poder, no caso mexicano, legitimado pelo nacionalismo do regime e o Volkgeist produzido, senão que são mais flexíveis tanto na dimensão espacial como na dimensão temporal ${ }^{202}$. Em primeiro lugar, a noção de territorialidades flexíveis vem a desafiar abertamente a hegemonia ideológica do Estado priísta e derruba a ideia de partido único e forte já que, seguindo a lógica do território dividido em escalas de ação e a territorialidade como relações sociais projetadas no espaço ${ }^{203}$, o Estado não controla o território nacional se não for apenas pela complacência e articulação interescalar das distintas relações de poder entre os distintos atores/agentes desde o macro até o micro. Em épocas de guerra contra as drogas, o narcotráfico oficialmente deixa de ser um conjunto de agentes/atores complacentes para com o Estado. Os territórios nos quais os carteis funcionam abandonam a concatenação interescalar e quebram a lógica de Estado hegemônico, criando territórios fora do controle do governo federal que, como foi mencionado, são flexíveis, quase líquidos e coexistem no espaço-tempo com os territórios do Estado. Por sua vez, são territórios que escapam da prisão da dimensão puramente física como a mesma noção de territorialidade acima explicitada o estabelece, existem em espaços e tempos definidos, podem " [...] ser antes instáveis que estáveis, ou, mesmo, ter existência regular mas apenas periódica (...) - e isto apesar que o substrato espacial permanece ou pode permanecer o mesmo" (LOPES DE SOUZA: 1995, p. 87).

O anterior pode conter parte da resposta do fracasso da guerra de Calderón, o ocaso da hegemonia do antigo partido da revolução e o recurso à negociação com os cartéis do novo PRI de Peña Nieto para manter o funcionamento do NarcoEstado. A guerra de Calderón, ao ser uma

\footnotetext{
201 "Os limites tendem a ser instáveis, com as áreas de influência deslizando por sobre o espaço concreto das ruas, becos e praças; a criação de identidade territorial é apenas relativa, digamos, mais propriamente funcional do que afetiva. O que não significa, em absoluto, que "ponto" não seja às vezes intensamente disputados, podendo a disputa desembocar em choques entre grupos rivais" (Ibidem, 88).

202 "Vários tipos de organização espaço-temporal podem surgir diante de nossos olhos, sem que haja uma superposição tão absoluta entre o espaço concreto com os seus atributos materiais e o território enquanto campo de forças. Um enraizamento tão forte como aquele focalizado por Ratzel não precisa existir para que se tenha territórios" (Ibidem, 86-87)

203 "Territórios, que são no fundo antes 'relações sociais projetadas no espaço' que espaços concretos (os quais são apenas os 'substratos materiais' das territorialidades) ". (Ídem).
} 
tentativa meta-política de legitimação eleitoral diante de uma votação sumamente dividida, estava destinada ao fracasso desde o começo por ter sido impulsionada mais como uma campanha de marketing ou uma continuação de campanha eleitoral do que uma guerra mesmo. Uma guerra ao ser declarada tem que se lutar, e se lutar com estratégias definidas desde distintas frentes de ataque como, por exemplo, ações de inteligência ou desarticulação econômica do inimigo. Porém, mais importante ainda é o conhecimento e o entendimento do território como espaço físico de ação e de uso por parte de atores que projetam as relações sociais existentes nesse espaço.

Uma campanha de marketing eleitoral não é uma guerra, não segue a estratégia necessária para ganhar uma guerra senão que segue a estratégia necessária para posicionar um produto, no caso, um presidente, e se houver de fato uma tentativa de articular uma estratégia bélica, estará destinada ao fracasso por emanar de uma fonte alheia. Porém, o discurso enviado aos cartéis foi de combate e luta armada, os cartéis responderam de essa maneira e com a estratégia adequada para ganhar uma guerra. Marcelo Lopes de Souza (1995) explicita a importância de ter uma noção adequada de território que vai além da sua concepção reducionista como substrato físico de produção e exploração de recursos e faz ênfase na importância de concebêlo como espaços de produção de relações de poder e dominação de distintos grupos sobre outros e as atividades materiais ali realizadas são apenas produto do anterior. $\mathrm{O}$ anterior é consoante com o mal-estar de Yves Lacoste (1993) quem afirma que a reflexão geopolítica foi extirpada do pensamento político reduzindo conflitos apenas às suas acepções economicistas ou de disputa política ${ }^{204}$.

Os massacres de San Fernando evidenciam também a paralisia institucional do Estado mexicano, nessa época sob o comando de Felipe Calderón, em matéria de acesso à justiça e dão os primeiros indícios da infiltração do narcotráfico no aparelho estatal, especificamente nas forças de segurança locais. Com um comunicado ${ }^{205}$ em agosto de 2015, o organismo Anistia Internacional alerta do perigo da mensagem enviada aos cartéis e ao crime organizado em geral

\footnotetext{
204 "Enquanto que, durante séculos, a geografia foi um saber político, por todas as evidencias, indispensável aos príncipes, aos chefes de guerra, aos grandes comissários do Estado, como aos poderosos homens de negócios, enquanto no século XIX a essa função eminentemente estratégica se acrescentava uma função ainda política, a de fazer conhecer sua pátria aos futuros cidadãos que são os jovens (...) a partir do momento em que os geógrafos ensinaram na Sorbonne - bem no início do século XX - , estes, por razoes complexas e sobretudo sob pretexto de cientificidade, julgaram bom expurgar seus discursos de qualquer referência ao político" (Lacoste, 1993, p; 260). ${ }^{205}$ Falta de justicia en cinco años de una masacre convierte a México en una 'zona de riesgo' para migrantes Disponível online através do site do organismo - http://amnistia.org.mx/nuevo/2015/08/21/falta-de-justicia-acinco-anos-de-una-masacre-convierte-a-mexico-en-una-\%E2\%80\%98zona-de-riesgo\%E2\%80\%99-paramigrantes/?o=n - publicado em 21 de agosto de 2015, acessado em maio de 2016.
} 
com a "escandalosa falta de investigações" em torno ao caso, lembrando que o tráfíco de migrantes é um dos negócios que involucram aos cartéis da droga. Ao mesmo tempo, levanta a questão da provável colusão dos Zetas implicados no massacre com agentes de segurança local.

Por sua vez, o portal de jornalismo de investigação Más de $72^{206}$ dedicado à investigação dos massacres de San Fernando denuncia o abandono do Estado mexicano aos migrantes centro e sul-americanos e a falta de investigação proposital sobre o massacre apontando que as vítimas "[...]fueron borradas por el Estado el cual no tuvo el interés en identificarlos y devolverlos a sus familias" 207 e denunciando inconsistências como a data do sequestro, os motivos do massacre, o número de sobreviventes e o papel da Marinha mexicana no evento ${ }^{208}$.

As inconsistências no caso começam com a data de sequestro reportada já que o Comunicado de Prensa 216/2010 da Secretaria de Marina - SEMAR foi publicado o dia 24 de agosto de 2010 e estabelece o dia 21 do mesmo mês como a data do sequestro e o dia 22 como a data da execução dos migrantes, dados que coincidem com a Recomendação No. 80/2013 da CNDH mas diferem do relatório 20100826 da Embaixada dos Estados Unidos no México que estabelece o dia 22 como a data do sequestro e informa que um migrante teria sido perdoado pelos traficantes ao aceitar a oferta de ingressar ao cartel e aponta o sumiço de uma mulher e uma criança do grupo. Ao mesmo tempo a informação oficial do governo e da CNDH mencionam apenas dois sobreviventes, enquanto a informação da Embaixada estadunidense e uma testemunha mencionam a existência de até 4 sobreviventes ${ }^{209}$. Finalmente, os motivos que levaram ao massacre ainda são discutidos já que, como foi mencionado, existem três linhas: a) foram assassinados por terem se recusado a formar parte do cartel; b) os coyotes não teriam pagado as cotas que os Zetas cobram para trasladar migrantes pelos territórios controlados; e c) foram os Zetas atrapalhando o negócio de tráfico de pessoas do rival Cartel del Golfo. O site Más de 72 denuncia que a PGR não aprofundou na investigação para descobrir os motivos.

\footnotetext{
${ }^{206}$ Más de 72 oferece duas entregas sobre os massacres de San Fernando, a primeira focando no massacre dos 72 migrantes e a segunda nas fossas clandestinas descobertas posteriormente - Disponível em: WWW.masde72.periodistasdeapie.org. $m x$ - acessado em maio de 2016.

207 Ídem.

208 "El contraste de diversas fuentes de información compiladas aquí exhiben y cuestionan la versión oficial de los hechos. Hay contradicciones en las fechas del secuestro y asesinato (...) así como los motivos de la masacre (...) Se pone en duda si los marinos descubrieron los cuerpos (...) si los sobrevivientes fueron más de tres (...). Ídem.

209 Comunicado de Prensa 216/2010: http://2006-2012.semar.gob.mx/sala-prensa/comunicados-2010/1436comunicado-de-prensa-216-2010.html - publicado em 24 de agosto de 2010; Recomendación No. 80/2013: http://www.cndh.org.mx/sites/all/doc/Recomendaciones/2013/Rec 2013 080.pdf - sem data de publicação; Cable 20100826 - http://nsarchive.gwu.edu/NSAEBB/NSAEBB445/docs/20100826.pdf
} 
Segundo a investigação do portal Más de 72, a teoria do recrutamento forçado foi a defendida pela PGR e pela CNDH, enquanto as dúvidas sobre o possível motivo financeiro de Los Zetas para atacar o negócio de tráfico de pessoas foram levantadas pela agência Insight Crime e pela própria Embaixada estadunidense e, finalmente, a teoria do assassinato por falta de pago dos coyotes foi levantado pelo jornal El Faro de El Salvador. Os argumentos utilizados são que: a) Não poderiam ter sido confundidos com sicários de outro cartel porque a maioria eram estrangeiros $^{210}$; b) O salário de USD $\$ 500.00$ por semana era muito generoso para um migrante e, sob ameaça de morte, é estranho que apenas um tenha aceitado a oferta ${ }^{211}$; e c) Os Zetas não pediram dinheiro como resgate dos sequestrados e a oferta de emprego parecia mais uma forma de brincar com eles e, portanto, seriam executados de qualquer forma, o qual aponta a um ataque premeditado contra os interesses financeiros do Cartel del Golfo ${ }^{212}$.

Finalmente, o portal The National Security Archive pertencente à George Washington University $^{213}$ expõe os documentos revelados pela PGR que formam parte da investigação em torno à participação de elementos da polícia municipal de San Fernando no sequestro dos migrantes e dos ônibus de passageiros que resultaram na descoberta de, pelo menos e segundo cifras oficiais, 196 cadáveres. Um documento liberado pela PGR é a Tarjeta Informativa, Asunto: Policías relacionados con el hallazgo de Cadáveres en las fosas clandestinas en San Fernando, Tamaulipas ${ }^{214}$ no qual se ordena a localização e apresentação diante da Subprocuraduría Especializada en Investigación de Delincuencia Organizada - SEIDO de 15 elementos da Polícia Municipal de San Fernando por suposta participação em atividades ilegais

\footnotetext{
210 "Initial reports said that the Zetas drug gang had kidnapped the group from the highway slaughtering them when they refused to join the organization (...) There is little reason the Zetas are desperate enough to resort to this kind of forced recruitment (...) the idea that the migrants were killed after being mistaken for reinforcements for another drug gang does not hold water, as they were all, or mostly, foreigners (...)" - Anniversary of Migrant Massacre in Mexico Brings Few Answers - Hannah STONE, em Insight Crime, publicado em 25 de Agosto de 2011, disponível em: http://www.insightcrime.org/news-analysis/anniversary-of-migrant-massacre-in-mexicobrings-few-answers - acessado em maio de 2016.

211 "The consulate does not question this story. Instead, the writer inserts a comment: 'The salary offered seems exceedingly generous and was likely not the actual salary, if any, they would have received if they had agreed to join the organization. End comment."' - US Cables Raise Questions about Mexico Migrant Masacres - Steven DUDLEY em Insight Crime, publicado em 20 de novembro de 2013, disponível em: http://www.insightcrime.org/news-analysis/picture-of-mexico-migrant-massacres-still-incomplete - acessado em maio de 2016.

212 "'One theory proposed by [name redacted] is that as the profits from the migrants' proposed illegal entry to the US were destined for the Gulf Cartel, their murders were a way for the Zetas to financially hurt the Gulf Cartel's interests, 'the cable says." Ídem.

${ }^{213}$ Acessível através de: www.nsarchive.gwu.edu

${ }^{214}$ Tarjeta Informativa - SEIDO - Documento disponível online em formato PDF através do site de The National Security Archive, disponível em: http://nsarchive.gwu.edu/NSAEBB/NSAEBB499/TarjetaInformativa.pdf - sem data de publicação, acessado em maio de 2016.
} 
com o cartel dos Zetas, entre as quais destacam a interceptação de pessoas para serem entregues ao cartel ${ }^{215}$ e o encobrimento das atividades dos traficantes ${ }^{216}$.

O caso dos massacres de San Fernando é especialmente alarmante pela capacidade do narcotráfico de controlar territórios inteiros e vias de comunicação para a realização de atividades ilegais que vão desde o tráfico da mercadoria até, e muito mais perigoso e infame, o tráfico de pessoas, especialmente migrantes. Se existe apatia ou uma negativa intencional da PGR de aprofundar nas outras possíveis linhas de investigação sobre os motivos do massacre dos 72 migrantes é porque a versão defendida (sobre a execução por terem se negado a virar sicários) faz que o massacre tenha sido um evento isolado com motivos específicos e, até certa medida, culpa dos próprios migrantes por: a) serem migrantes e b) terem rejeitado a oferta que eventualmente levou à sua execução. Legitimar mediante uma investigação às outras linhas possíveis implicaria aceitar que: 1) o tráfico de pessoas é um problema que existe e está fora de controle; 2) os migrantes encontram-se desprotegidos e à mercê dos cartéis; 3) o narcotráfico controla territórios e vias de comunicação; e 4) que não é um caso isolado senão uma cotidianidade.

A posterior descoberta de fossas clandestinas com o número oficial de 196 cadáveres refuta a posição do então governo de Calderón. Evidenciam a atuação em liberdade total dos Zetas no município de San Fernando e confirma a colusão da Polícia Municipal com o cartel através da Tarjeta Informativa que foi muito bem guardada pela PGR e desclassificada apenas após o final do mandato de Calderón.

As investigações em torno a este caso evidenciam o desdém do Estado mexicano para com a população civil, especialmente as parcelas periféricas que constituem ao Outro-indesejável que vive e morre na ignominia. O massacre de $\mathbf{7 2}$ seres humanos não foi o suficientemente chocante já que eram migrantes: a periferia da periferia. Um relatório diplomático da Embaixada estadunidense no México ${ }^{217}$ levanta a questão de que a descoberta de 196 cadáveres resultou

215 'D. En declaraciones, Álvaro Alba Terrazas (a) 'El Junior' refiere en declaración que sabe de la participación de elementos de la dirección de seguridad pública y tránsito del municipio de San Fernando, Tamaulipas (...) 'sé, que los policías y tránsitos de San Fernando ayudan a la organización de los Zetas, porque en lugar de cuando detienen a la gente se la lleven al Pentágono, es decir a la cárcel municipal, se los entregan a los zetas, el mero bueno es un policía viejito y otro que se llama Oscar Jaramillo quienes reciben dinero de la organización para colaborar. " Ídem.

216 "B. En base a las declaraciones (...) refiere participación de elementos de la Policía Municipal de San Fernando, desde cubrir labores de halconeo, intercepción de personas y omisión en su deber en la observación de delitos cometidos por miembros de la organización criminal 'Los Zetas', citando además que recibían pago por parte de esta organización criminal (...)" Ídem.

217 "Body Count in San Fernando Continues to Rise: 2. (SBU) The total number of bodies found in mass graves in the San Fernando area has reached 196 and is expected to rise, according to official sources (Reftel A). SEDENA 
para o Estado mais desconfortável do que chocante já que esse foi o número final reportado pelo governo, embora o Exército e a Marinha tenham declarado, após os cadáveres terem atingido essa cifra, que a previsão era encontrar ainda mais conforme as escavações avançassem. Nunca aconteceu.

and SEMAR continue to search for new bodies, while the federal Office of Special Investigations of Organized Crime (SIEDO) and state officials work to identify the remains. " Comunicado Diplomático - Data de revelação: 8 de agosto de 2012, disponível online em formato PDF através do site de The National Security Archives em: http://nsarchive.gwu.edu/NSAEBB/NSAEBB445/docs/20110429.pdf - acessado em maio de 2016. 
CAPÍTULO IV

\section{Ayotzinapa}

"Es algo dificil crecer sabiendo que la cosa donde podemos agarrarnos para enraizar está muerta."

(Juan Rulfo, El llano en llamas, 1953)

Os eventos acontecidos na cidade de Iguala no dia 26 de setembro de 2014 marcaram para sempre à sociedade mexicana e ao Estado e, para fins da presente dissertação, representam o ponto histórico no qual a existência do NarcoEstado foi revelada para o país e para o mundo. $\mathrm{O}$ ataque direto e premeditado em detrimento dos estudantes da Escola Normal Rural "Raúl Isidro Burgos" de Ayotzinapa, Guerrero, é resultado direto da escalada de violência começada por Felipe Calderón e continuada, sob os próprios termos, por Enrique Peña Nieto.

Ayotzinapa, em relação aos dois casos apresentados anteriormente, encontra-se mais próximo da lógica de ação que aconteceu em Tlatlaya do que aconteceu em San Fernando. Se bem os três eventos são resultado direto do combate militarizado aos cartéis, são ao mesmo tempo parte de dois momentos diferentes da guerra.

O primeiro, o de San Fernando, está inserido na etapa calderonista do conflito que, como já foi mencionado, se caracterizou por ser mais uma estratégia mediática para posicionar um produto na opinião pública e legitimá-lo politicamente. É também um momento de combate frontal aos cartéis fazendo ênfase na espectacularidade das armas e da mobilização militar para dar aparência de fortaleza bélica do Estado, porém, sem estratégia projetada para ganhar de fato o conflito nem de proteção à população civil vulnerável à violência dos cartéis e dos militares. $\mathrm{O}$ anterior provocaria o fortalecimento armamentista dos cartéis, a sua infiltração nas esferas de 
administração política e a perda de territórios para o narcopoder. É uma etapa caracterizada também por dois tipos de atentados contra a população: 1) por parte dos cartéis como o ataque com granadas no centro da cidade de Morelia ou o ataque terrorista ao Casino Royale na cidade de Monterrey ${ }^{218}$; e 2) tragédias provocadas diretamente ou favorecidas pela negligência do Estado como o incêndio na Creche $\mathrm{ABC}^{219}$ ou os próprios massacres de San Fernando.

No segundo momento, o de Tlatlaya e Ayotzinapa, podemos considerar outros eventos como o assassinato do fotojornalista Rubén Espinosa ${ }^{220}$ e os ataques diretos contra jornalistas no estado de Veracruz ${ }^{221}$, governado por Javier Duarte; as desaparições forçadas em Chilapa ${ }^{222}$, Guerrero;

${ }^{218}$ Casino Royale, Monterrey, 25 de agosto de 2011, terrorismo/massacre: "Un total de 53 personas fueron asesinadas esta tarde en un ataque con granadas perpetrado por un comando de seis sicarios, agresión que derivó en un incendio en el interior del centro de apuestas Casino Royale, en una exclusiva zona al poniente de esta capital (...)”. Redacción - Atacan con granadas casino en Monterrey; hay 53 muertos em Proceso disponível em: http://www.proceso.com.mx/279521/atacan-con-granadas-casino-en-monterrey-seis-muertos-y-10-heridos acessado em maio de 2016.

${ }^{219}$ Foi o incêndio de uma creche na cidade de Hermosillo, Sonora; morreram calcinadas 49 crianças e 106 resultaram feridas. As pericias apontavam a negligencia das autoridades já que a creche não contava com as condições necessárias de funcionamento, mas mesmo assim foi aprovada pelo governo do estado. As acusações chegavam até o próprio governador do estado, Eduardo Bours, e familiares da então primeira dama e esposa de Felipe Calderón; houveram condenações apenas para funcionários de baixo nível enquanto os altos mando $\mathrm{s}$ permaneceram intocados - Documento: La SCJN propuso em 2010 responsabilizar a altos funcionários por caso $A B C$ - Redacción AN, publicado em 5 de junho de 2014, disponível em: http://aristeguinoticias.com/0506/mexico/documento-la-scjn-propuso-en-2010-responsabilizar-a-altosfuncionarios-por-caso-abc/ - acessado em maio de 2016.

${ }^{220}$ Assassinado na Cidade do México após ter fugido do estado de Veracruz por ameaças - Este caso será retomado nos próximos capítulos.

${ }^{221} \mathrm{O}$ estado de Veracruz sob o governador priísta Javier Duarte se caracteriza pela violência contra o periodismo; até fevereiro de 2016 somavam 17 os periodistas assassinados diante da impassibilidade do governador quem afirmou insistentemente que em Veracruz "não acontece nada" - El Infierno de Javier Duarte - Noé ZAVALETA em Poceso, publicado em 30 de junho de 2016, disponível em: http://www.proceso.com.mx/445799/infiernojavier-duarte - acessado em julho de 2016.

${ }^{222}$ Chilapa, 9 de maio de 2015, desaparições forçadas: "Se denunciaron 16, la fiscalía estatal investiga 15, pero los testimonios hablan de casi 30 personas desaparecidas en este municipio donde se enfrentan 'Los Rojos' y 'Los Ardillos', como se denominan los grupos criminales que se han disfrazado de 'policías comunitarios” (...) En Chilapa, la policía municipal esta desarmada. Las fuerzas federales, militares y policiacas, no intervinieron en los sucesos del 9 de mayo (...) y ha calculado que son más de 200 las personas desaparecidas"-Ayotzinapa y los nuevos crímenes de lesa humanidad - Jenaro VILLAMIL em Proceso, publicado em 26 de maio de 2015, disponível em: http://www.proceso.com.mx/405477/ayotzinapa-y-los-nuevos-crimenes-de-lesa-humanidad acessado em maio de 2016. 
os massacres de Apatzingán ${ }^{223}$ e Ecuandureo ${ }^{224}$; o ataque em Ostula ${ }^{225}$; as detenções arbitrárias de manifestantes e estudantes; o ataque com armas de fogo contra estudantes por parte de policiais vestidos de civil na Universidad Nacional Autónoma de México - UNAM e o posterior estado de sitiamento que o campus universitário viveu com confrontos entre estudantes e o batalhão de choque. Esse segundo momento se caracteriza pela continuação do combate armado ao narcotráfico, porém sem a midiatização calderonista. A estratégia utilizada agora é renegociar com os cartéis a antiga pax priísta, só que agora em igualdade de circunstâncias e, finalmente, se caracteriza porque todos eventos mencionados foram dirigidos contra a população civil com acusações de participação tanto de traficantes como de agentes do Estado sendo, que em cada uma delas, a participação do Poder Judiciário, através da PGR, tem sido altamente questionada pela sua parcialidade em detrimento das vítimas.

O caso aqui apresentado é uma história que, até o momento da elaboração da presente dissertação, encontra-se ainda em desenvolvimento, mas oferece o material suficiente para aprofundar nos eventos da noite do dia 26 de setembro de 2014. O sumiço de 43 dos estudantes atacados desencadearam a movimentação da população civil em protestos massivos que exigiam justiça e uma investigação séria que atingisse à própria classe política tanto do estado de Guerrero como a do governo federal, exigindo abertamente a renúncia do presidente Enrique Peña Nieto por incompetência e suspeitas de colusão com o narcotráfico. Em paralelo causou a mobilização do aparelho estatal repressivo para conter à população utilizando métodos intervenção e contenção civil tradicionais da época dura do regime ${ }^{226}$, tais como o uso de

\footnotetext{
${ }^{223}$ Apatzingán, 6 de janeiro de 2015, massacre: "Los dos ataques ocurridos la mañana del pasado 6 de enero en Apatzingán, con saldo de 16 civiles muertos (...) no fueron sólo obra de la Policía Federal, como se creía. Al menos en una de las agresiones participaron soldados de la XLIII Zona Militar, según se desprende de testimonios incluidos en las averiguaciones previas y declaraciones ministeriales (...)". - Apatzingán: también los militares atacaron - Laura CASTELLANOS em Processo, publicado em 24 de maio de 2015, disponível em: http://www.proceso.com.mx/405135 - acessado em maio de 2016.

${ }^{224}$ Ecuandureo, 22 de maio de 2015, execução sumária: "La versión oficial habla de un 'enfrentamiento' entre presuntos sicarios del Cartel Jalisco Nueva Generación - CJNG contra policías federales (...) La versión oficial y las imágenes que han circulado en redes sociales se contradicen. Los 42 presuntos narcotraficantes son jóvenes desarmados, con indicios claros de ejecución. Crece la versión de una 'venganza' de las fuerzas policiales y militares tras el derribo del helicóptero en los narcobloqueos del 1 de mayo (...)". - Ayotzinapa y los nuevos crímenes de lesa humanidad - Jenaro VILLAMIL em Proceso. Op. Cit. Grifos nossos.

${ }^{225}$ Ostula, 19 de julho de 2015, ataque militar: "La comunidad indigena de Santa María Ostula confirmó hoy que dos menores y un adulto perdieron la vida y un número indeterminado resultó herido en el operativo conjunto que desplegó ayer en esa región de la costa michoacana el Grupo de Coordinación Michoacán, conformado por fuerzas federales, estatales y municipales." - Tres muertos, entre ellos dos niños, saldo del ataque del Ejército en Aquila - Francisco CASTELlANOS em Proceso, publicado em 20 de julho de 2015, disponível em: http://www.proceso.com.mx/411055/muere-otro-menor-tras-ataque-del-ejercito-a-civiles-en-aquila - acessado em maio de 2016.

226 'The Mexican 'drug war' has taken a turn for the worse. Since the return of the old guard Party of the Institutional Revolution (PRI) to the presidency in 2012, violence has expanded and increasingly targeted political activists, journalists and human rights defenders. And two recent massacres committed by government officials
} 
halcones $^{227}$ com a cumplicidade e alinhamento total de Miguel Ángel Mancera (PRD), chefe de governo do Distrito Federal.

Por sua vez, o aparelho judiciário do Estado, em submissão total ao Poder Executivo, entregaria uma "verdade histórica" confortável para o Estado produto das investigações da PGR sob o comando de Jesús Murillo Karam, versão que seria imediatamente rejeitada por organismos internacionais como a Organização dos Estados Americanos - OEA e a própria ONU. Ressalta a participação do Equipo Argentino de Antropologia Forense - EAAF $^{228}$ e o Grupo Interdisciplinario de Expertos Independientes - $\mathrm{GIEI}^{229}$ cujas investigações independentes ajudaram a impedir o arquivamento do caso Ayotzinapa.

\section{Os Eventos}

Os eventos acontecidos na noite do 26 de setembro de 2014 na cidade de Iguala, no estado de Guerrero, foram parte de uma longa história de conflito entre estudantes normalistas e agentes do Estado após a emblemática insurreição de Lucio Cabañas, graduado da Escola Normal Rural "Raúl Isidro Burgos", e um grupo de normalistas na década de 1970 na selva guerrerense. O GIEI, no seu primeiro informe sobre os acontecimentos ${ }^{230}$, reúne informação de

indicate that the country may be headed towards a rerun of the 'dirty wars' of the 1970s, in which the government hunted down and killed or jailed thousands of activists."- Massacred Democracy in Mexico - John M. ACKERMAN em The World Post, publicado em 10 de julho de 2014, disponível em: http://www.huffingtonpost.com/john-m-ackerman/massacred-democracy-in-mexico_b_5948884.html - acessado em maio de 2016.

${ }^{227}$ O termo "halcón" faz referência a grupos paramilitares de indivíduos infiltrados em protestos ou manifestações com a intenção de provocar confrontos violentos contra as forças de segurança ou incentivar ao vandalismo para, de esta forma, provocar a intervenção e o uso da força por parte de policiais ou militares. Os "Halcones" originais foram utilizados no Massacre de Corpus Christi na Cidade do México em 1971 contra estudantes.

${ }^{228}$ Equipo Argentino de Antropologia Forense - EAAF: Organização cientifica, não governamental e sem fins de lucro que aplica as ciências forenses - principalmente a antropologia e arqueologia forenses - à investigação de violações aos direitos humanos no mundo. Fundada em 1984 para investigar as desaparições forçadas da ditadura argentina. Site oficial: http://eaaf.typepad.com/eaaf_sp/

${ }^{229}$ Grupo Interdisciplinario de Expertos Independientes - GIEI: Grupo criado pela Comissão Interamericana de Direitos Humanos para brindar assistência técnica internacional na investigação da desaparição forçada dos 43 estudantes de Ayotzinapa. Site oficial: http://prensagieiayotzi.wix.com/giei-ayotzinapa

${ }^{230}$ Informe Ayotzinapa I: Investigación y primeras conclusiones de las desapariciones y homicidios de los normalistas de Ayotzinapa - Grupo Interdisciplinario de Expertos Independientes - GIEI; disponível online através do site official do GIEI - http://prensagieiayotzi.wix.com/giei-ayotzinapa\#!informe-/c1exv - acessado em maio de 2016. 
pelo menos cinco confrontos violentos entre normalistas e agentes do Estado entre novembro de 2013 e janeiro de $2014^{231}$ nos quais os policiais utilizaram armas de fogo, gás lacrimogêneo e golpes para conter e dispersar aos normalistas, os quais frequentemente protestavam seja por questões acadêmicas ou para tomar posse de ônibus de passageiros de maneira clandestina, atividade frequente e usualmente sem necessidade de recorrer à violência ${ }^{232}$. Dos confrontos relatados pelo GIEI resultaram, pelo menos, 41 detidos, 3 feridos e 2 mortos.

No dia dos acontecimentos, os normalistas planejavam outra toma de ônibus com a intenção de utilizá-los para viajar à Cidade do México e participar do protesto anual do dia 2 de outubro para comemorar o Massacre de Tlatelolco de 1968. A toma dos ônibus começou desde o dia 23 de setembro na cidade de Chilpancingo, capital do estado, segundo o relatado pelo GIEI, mencionando que em paralelo a atividade da Polícia Federal nas estradas e pedágios havia aumentado consideravelmente ${ }^{233}$. Os estudantes se dirigiram para a cidade de Iguala e, no caminho entre Chilpancingo e a Cidade do México, coincidiriam com um evento político de Maria de los Ángeles Pineda, esposa de José Luis Abarca (PRD), prefeito da cidade. Uma vez em Iguala, procederiam a tomar mais ônibus da rodoviária da cidade, em todo momento sob o seguimento constante do Centro de Control, Comando, Comunicación y Cómputo - C-4. Portanto, as corporações policiais estatais e federais, assim como o exército, monitoravam aos estudantes desde a sua saída de Chilpancingo ${ }^{234}$.

Posteriormente os cinco ônibus tomados pelos estudantes saíram da rodoviária e se dividiram em três rotas distintas. O primeiro ataque começou aproximadamente às 21:30 horas com uma perseguição da polícia local de Iguala que atirava para o ar e posteriormente contra os ônibus. Os próprios estudantes e testemunhas na rua afirmam que a polícia de Iguala portava equipamento muito melhor do normal e algumas das camionetes utilizadas não eram as habituais $^{235}$. O tiroteio continuou mesmo após os ônibus terem parado o seu caminho e os

\footnotetext{
${ }^{231}$ Ídem. Pp: 15-16-17

232 "Las actividades de boteo o toma de autobuses se venían realizando desde hacía muchos años en Ayotzinapa y otras muchas escuelas normales del país, sin que hubieran tenido una reacción violenta indiscriminada con armas de fuego (...)” Ídem. Pág: 21.

233 "La presencia de la Policía Federal fue también señalada por algunos de sus integrantes. Uno de los trabajadores de la caseta de cobro señaló en su declaración ante la PGR la presencia de la policía federal y de militares en la caseta de cobro ese día 26." Ídem, pag: 26.

234 "A las 17:59 horas, el Centro de Control de la Policía Estatal o C-4 de Chilpancingo, reportó vía telefónica a la Policía Federal con sede en Iguala, de dos autobuses Estrella de Oro con estudiantes de la Escuela Normal Rural de Ayotzinapa, los cuales fueron monitoreados por el C-4 de Iguala." Ídem, pág: 29.

235 "Los normalistas coinciden en que los policías de las patrullas del Periférico norte llevaban mejor equipo que el habitual de la policía municipal, porque llevaban casco, pasamontañas, ropa de manga larga, coderas, rodilleras, chalecos y guantes (...) Una de las patrullas tenía el número 302 y que con letras que decía 'Policía Municipal', según los testigos, era una camioneta Ranger que no era habitual para la policía de Iguala (...)”. Ídem, pág: 52.
} 
normalistas terem descido. Os normalistas relatam que já nesse momento haviam alguns feridos e os policiais bloqueavam a chegada das ambulâncias ao mesmo tempo que continuam as declarações sobre carros diferentes aos habitualmente usados pela polícia ${ }^{236}$.

Os ataques continuaram com os outros ônibus que tinham tomado rotas distintas. Seguindo o mesmo padrão de operação, os ônibus foram alvejados por carros da polícia até pararem e, uma vez detidos, os tiros continuaram até que os normalistas se entregaram. Em paralelo, outro ônibus dos normalistas foi atacado e parado pela polícia, porém, o GIEI relata que todos os passageiros do ônibus Estrella de Oro 1531 encontram-se, até hoje, desaparecidos. ${ }^{237}$ Testemunhas e elementos do exército que se encontravam perto da cena relatam que os policiais jogaram bombas de gás lacrimogêneo, equipamento que não é comum para a polícia local de Iguala, para posteriormente subir aos normalistas nas viaturas e serem levados para fora da cidade $^{238}$. Os normalistas restantes dos outros ataques foram levados para centros de detenção dentro de Iguala e, alguns, foram posteriormente levados para fora da cidade e, igualmente, encontram-se desaparecidos até hoje ${ }^{239}$. Dos eventos anteriores, o GIEI determina que 43 estudantes normalistas foram desaparecidos forçosamente desde dois lugares distintos.

Além dos ataques aos normalistas, o GIEI relata também outros ataques simultâneos contra a população civil por parte da polícia de Iguala perto do estádio de futebol da cidade em agravio do ônibus do time Los Avispones de Chilpancingo na estrada que une ambas as cidades. $\mathrm{O}$ ônibus teria sido detido por homens armados que abririam fogo. Um dos jogadores perderia a vida enquanto o motorista do ônibus faleceria posteriormente no hospital, além de vários feridos. Os atacantes, ao momento de fugir, abriram fogo contra os carros que passavam pela zona, uma senhora de 40 anos foi assassinada pelos tiros dos atacantes ${ }^{240}$. A versão em torno

\footnotetext{
236 "Los disparos de la policía alcanzaron a Aldo Gutiérrez en la cabeza (...) una mujer que atendía el teléfono le dijo que no le creía la información y posteriormente a otro normalista que llamó al mismo teléfono le respondieron diciendo que la policía no había dejado pasar a la ambulancia (...) Según varios normalistas, llegaron 3 patrullas, se veían como federales, pero no eran federales (...)” Ídem. Pág: 53-54-55.

237 "Todos los normalistas que iban en ese autobús fueron detenidos y están desaparecidos, por lo que no hay testimonios directos de lo sucedido (...)” Ídem, pág. 61.

238 "El militar observó cómo los policías arrojaron dos granadas de gas lacrimógeno al interior del autobús para sacar a los jóvenes. Se da la circunstancia de que, según las fuentes consultadas, la policía municipal no tiene normalmente este tipo de material antidisturbios (...) Según el testigo, los estudiantes subidos en las patrullas habrían sido llevados en dirección a Huitzuco, es decir en dirección contraria a Iguala. " Ídem, p. 65-66.

239 "Poco antes, a las 23:19 horas (...) una cámara recogió imágenes de tres patrullas de la policía de Iguala llevándose a personas detenidas en dirección a la salida hacia Taxco. ” Ídem, pág. 72

${ }^{240}$ Durante el viaje (...) el autobús fue primero detenido por hombres armados y después atacado con armas de fuego (...) acabando con la vida del estudiante Josué García Evangelista e hiriendo de extrema gravedad al conductor, Victor Emanuel Lugo Ortiz, quien murió poco después de llegar al hospital (...) Al salir del lugar, los atacantes dispararon contra otros carros que pasaban por esa zona (...) En ese episodio murió la señora Blanca Montiel, de 40 años, quien fue tiroteada cuando pasaba en un taxi en dirección contraria (...). "' Ídem, pág: 113114-115.
} 
ao ataque contra este ônibus em particular afirma que foram confundidos por normalistas, especificamente um $5^{\circ}$ ônibus que teria ido por uma rota diferente a dos outros normalistas. Se menciona também que os atacantes estariam usando fardas da polícia municipal de Iguala ${ }^{241}$.

Finalmente, a descoberta do corpo sem vida de Julio César Mondragón, normalista que fugiu durante o segundo ataque anteriormente mencionado, significou, segundo o GIEI, uma "[...] muestra del nivel de atrocidades cometidas esta noche, esta vez contra uno de los normalistas que quedó aislado del resto" ${ }^{242}$. Isto porque o cadáver foi encontrado com marcas visíveis de tortura.

\footnotetext{
“La autopsia del cuerpo de Julio César Mondragón reveló visibles muestras de tortura, arrancamiento de piel y músculos faciales, múltiples fracturas craneales así como lesiones internas con hemorragias en diferentes vísceras como consecuencia de torturas (...) el profesor de medicina legal de la Universidad del País Vasco, Francisco Etxeberría, señala que Julio César Mondragón Fontes sufrió lesiones previas en un cuadro de poli contusión en diversas partes del cuerpo con fracturas costales en ambos hemitórax y hematoma retroperitoneal como consecuencia de golpes en abdomen o espalda. Y posteriormente, en un segundo momento, las fracturas craneales se dieron todavía en vida, aunque no está claro su mecanismo de producción. Y, según la autopsia, su cuerpo apareció con lesiones que serían postmortem en la cara, que no puede definirse si son por maniobras intencionales o por fauna (...)". Informe Ayotzinapa. Investigación y primeras conclusiones de las desapariciones y homicidios de los normalistas de Ayotzinapa. p. 124.
}

Isto é, o corpo foi encontrado com o rosto arrancado, sem pele, músculos e olhos.

Os eventos da noite de Iguala deixaram, segundo cifras do GIEI, mais de 180 pessoas diretamente atingidas pelos eventos violentos: 1) apontam a execução extrajudiciária de seis pessoas (incluído Julio Cesar Mondragón, previamente torturado), duas pessoas mais com tiros à queima-roupa e três pessoas assassinadas durante o ataque ao ônibus de Los Avispones; 2) mais de 40 feridos variando entre distintos graus de seriedade dos ferimentos (incluído Aldo Gutiérrez quem ficou em estado de coma após o tiro na cabeça); 3) outros 80 normalistas e os restantes 30 passageiros do ônibus de Los Avispones que sofreram "distintas formas de perseguição e atentados contra as suas vidas”; 4) a desaparição forçada de 43 normalistas; e

\footnotetext{
241 Ídem, pág: 116.

242 Ídem, pág. 122.
} 
5) os eventos violentos atingiram a pelo menos 700 familiares diretos das vítimas dos ataques em Iguala ${ }^{243}$.

Chama a atenção a participação direta da polícia municipal no ataque aos normalistas, os quais são um grupo considerado combativo e em oposição direta ao Estado mexicano, assim como as declarações sobre o equipamento moderno e camionetes que não correspondem tradicionalmente às utilizadas pela polícia de Iguala e a intensidade da violência crescente utilizada pelos agressores em agravio de "civiles desarmados y em actitud de escape"244. Em paralelo, chama a atenção a absoluta falta de ação do Exército Mexicano, particularmente o $27^{\circ}$ Batalhão de Iguala diante dos fatos que aconteciam e dos quais foram testemunhas diretas e indiretas mediante a informação providenciada pelo C-4, o qual os monitorou constantemente desde o momento que os normalistas saíram de Chilpancingo.

Estes eventos chocariam à sociedade mexicana desde o primeiro momento da sua difusão na mídia e mobilizariam tanto aos cidadãos em protestos massivos reclamando a localização e apresentação com vida dos 43 estudantes desaparecidos durante os próximos meses, criando um ambiente de tensão na Cidade do México que desencadearia uma serie de confrontos entre as forças de segurança da Capital e os cidadãos dos quais se considerarão dois para efeitos da presente dissertação: 1) o protesto massivo e a repressão acontecida no dia 20 de novembro de 2014 no marco da Acción Global Ayotzinapa, em conjunto com as detenções arbitrarias que aconteceriam durante e posterior ao evento; e 2) os ataques aos estudantes com armas de fogo por parte de policiais vestidos de civis dentro do campus principal da UNAM, o sitiamento do mesmo pelo batalhão de choque e os confrontos violentos entre estudantes e policiais nas imediações do campus.

Porém, antes de entrar na resposta cidadã em vista dos acontecimentos, é necessário falar da forma em que as investigações em torno ao ataque de Iguala e o sumiço dos normalistas foram conduzidas. Nos dias posteriores se iniciariam uma serie de investigações tanto do Estado através da PGR e, em paralelo, a intervenção de organismos estrangeiros independentes como o próprio GIEI e o EAAF, em conjunto com visitadores de direitos humanos da ONU. Por um lado, Jesús Murillo Karam, ex titular da PGR e Tomás Zerón de Lucio, diretor da Agencia de Investigación Criminal - AIC, levariam a cabo uma investigação cheia de dúvidas, falhas de procedimento e versões que criminalizariam aos normalistas, reconheceriam a participação do

\footnotetext{
243 Ídem, pág: 311-312.

244 Ídem, pág: 313.
} 
narcotráfico apenas no nível municipal e protegeriam às corporações policiais e ao Exército Mexicano, culminando na declaração da "verdade histórica" do acontecido e o arquivamento do caso. Por outro lado, o GIEI levaria a cabo uma investigação independente que derrubaria a versão oficial através da publicação de um segundo informe sobre Ayotzinapa ${ }^{245}$ que aponta à premeditação do ataque, a colusão e infiltração do narcotráfico no aparelho estatal para além do nível municipal e o ataque motivado por fins políticos.

\section{As investigações}

Como todo acontecimento da magnitude do ataque em Iguala, as reações não são imediatas, os fatos demoram um pouco em serem difundidos e as autoridades, quanto mais implicadas, mais demorarão em agir. No caso de Ayotzinapa, as primeiras reações aconteceriam no dia 30 de setembro, isto é, quatro dias após os ataques em Iguala, quando autoridades da Procuraduría General de Justicia del Estado (de Guerrero) - PGJE realizam a detenção de 22 policiais municipais de Iguala sob cargos de homicídio em agravio de seis pessoas e crimes de abuso de autoridade e lesões contra civis e são trasladados ao Centro de Reinserción Social - CERESO de Las Cruces em Acapulco ${ }^{246}$. Em conjunto, o prefeito da cidade, José Luis Abarca se afasta do cargo e foge junto com a sua esposa María de los Ángeles Pineda no momento em que a PGJE começa a busca dos normalistas desaparecidos. Uma ordem de apresentação é emitida contra o prefeito ${ }^{247}$.

Até esse momento vemos que as investigações estavam sendo comandadas pelas instâncias estatais, porém, no dia 4 de outubro de 2014, após a fuga do prefeito José Luis Abarca e a

\footnotetext{
${ }^{245}$ Informe Ayotzinapa II: Avances y nuevas conclusiones sobre la investigación búsqueda y atención a las víctimas - Disponível online no portal do GIEI - http://prensagieiayotzi.wix.com/giei-ayotzinapa\#!informe-/c1exv 246 "Hoy en la tarde los 22 policías de Iguala acusados y detenidos por el presunto homicidio de seis personas fueron trasladados al Centro de Reinserción Social (CERESO) de Las Cruces, en Acapulco, donde enfrentaran un proceso jurídico por el delito de homicidio" - Consignan a 22 policías de Iguala por presunto homicidio de 6 personas - Redacción Animal Político, publicado em 29 de setembro de 2014, disponível em: http://www.animalpolitico.com/2014/09/reconoce-pgj-guerrero-abuso-de-autoridad-de-policias-de-iguala-contranormalistas-de-ayotzinapa/ - acessado em maio de 2016.

${ }^{247}$ Normalistas cumplen dos meses desaparecidos: cronología del caso Ayotzinapa - Redacción Animal Político, publicado em 26 de novembro de 2014, disponível em: http://www.animalpolitico.com/2014/11/cronologia-eldia-dia-del-caso-ayotzinapa/ - acessado em maio de 2016.
} 
descoberta de seis fossas clandestinas com 28 cadáveres nas proximidades de Iguala ${ }^{248}$, a Procuraduría General de la República - PGR assume as investigações sob o comando de Jesús Murillo Karam e, a partir desse momento viraria um assunto da índole federal ${ }^{249}$. Ressalta a demora de 10 dias da PGR para assumir um caso de desaparição forçada e delinquência organizada que qualificam como delitos que devem ser investigados por esse organismo diretamente, situação levantada pelo GIEI no Informe Ayotzinapa $\mathrm{I}^{250}$. No entanto, a demora da PGR para assumir o cargo chama mais atenção por dois motivos: 1) o prefeito da cidade fugiu nesse intervalo; e 2) o GIEI aponta que as primeiras 72 horas são vitais na busca de pessoas vítimas de desaparição forçada, especialmente se os perpetradores foram agentes do Estado já que aumenta a facilidade e o poder de ocultar aos desaparecidos mediante o conhecimento de rotas e contatos institucionais, assim como a capacidade de alterar registros, modificar cenas ou atrapalhar investigações ${ }^{251}$. Não está demais dizer que 10 dias de demora equivalem a 168 horas a mais do indicado.

As investigações realizadas pela PGR de Murillo Karam giraram em torno da suposta participação de sicários do cartel dos Guerreros Unidos em colusão com policiais municipais e funcionários de Segurança Pública da cidade, os quais, sob ordens do prefeito José Luis Abarca e a sua esposa, teriam atacado, capturado e entregado aos estudantes aos sicários do cartel mencionado para posteriormente serem assassinados. Abarca e a sua esposa foram acusados pela PGR de terem nexos com o narcotráfico, particularmente o cartel de Beltrán Leyva e vínculos familiares com líderes do cartel dos Guerreros Unidos. Esta primeira teoria da PGR afirma que Abarca teria ordenado o ataque para impedir que os normalistas atrapalhassem o evento político da sua esposa que estava acontecendo simultaneamente com o passo dos ônibus dos normalistas pela cidade de Iguala ${ }^{252}$. Porém, o Informe Ayotzinapa I do GIEI estabelece

\footnotetext{
248 "El titular de la PGR confirmó que los 28 cuerpos hallados en las primeras fosas no son de los normalistas." Ídem.

249 “(...) la Procuraduría de Guerrero confirmó el hallazgo de seis fosas clandestinas (...) posteriormente se dio a conocer que había 28 cuerpos en ellas (...) La Procuraduría General de la República (PGR) atrajo el caso de los normalistas, a 10 días de su desaparición." - Ídem.

250 "La facultad de atracción no fue ejercida de forma inmediata por la PGR, como le faculta la ley, y hubiera sido lo aconsejable ante un hecho de tal gravedad”. Informe Ayotzinapa I, Pág. 177

251 Ídem, pág: 211.

252 "Un informe del Centro de Investigación y Seguridad Nacional (CISEN) confirma que José Luis Abarca Velázquez, alcalde de Iguala con licencia, tiene estrechos vínculos con grupos del crimen organizado que operan en la zona note del estado de Guerrero (...) señala que (María de los Ángeles) Pineda Villa le ordenó a su jefe de seguridad que (...) no debia permitir que los estudiantes de Ayotzinapa llegaran al lugar del evento, para lo cual debía implementar un operativo que frenara su avance y los replegara." - Edil de Iguala era "lavador" de los Beltrán; hizo gran fortuna - Redacción Red Política, publicado em 7 de outubro de 2014, disponível em: http://www.redpolitica.mx/edil-de-iguala-era-lavador-de-los-beltran-hizo-gran-fortuna - acessado em maio de 2016.
} 
que o evento começou às 19 horas e terminaria 40 minutos depois, momento no qual os normalistas encontravam-se ainda fora da cidade ${ }^{253}$.

Com a linha de investigação anterior ainda faltaria saber o paradeiro dos estudantes, ainda oficialmente considerados desaparecidos. Durante os próximos dias, elementos da Polícia Federal e agências de investigação, junto com a PGR continuariam fazendo descobertas de fossas clandestinas ${ }^{254}$. Segundo análises periciais do EAAF, os corpos não correspondiam aos 43 normalistas desaparecidos. A pergunta lógica: então de quem são?

A teoria da PGR sobre o paradeiro dos desaparecidos começaria se articular com a teoria do ataque em Iguala seguindo duas possíveis motivações: 1) a ordem de Abarca para impedir que chegassem perto do evento da sua esposa (descartada posteriormente); ou 2) terem sido confundidos com um grupo de traficantes rival dos Guerreros Unidos, ou bem, terem membros infiltrados ${ }^{255}$. Após o ataque, a polícia municipal de Iguala teria entregado aos 43 estudantes, divididos em dois grupos, à polícia municipal de Cocula (cidade vizinha de Iguala) e aos Guerreros Unidos ${ }^{256}$. O segundo motivo foi o considerado oficial pela PGR como parte da sucessão de eventos na linha de investigação privilegiada. Porém, existem dois problemas claramente visíveis e conhecidos: a) a criminalização das vítimas facilitado por pertencerem a um setor populacional historicamente desconfortável em termos políticos, criminalização que daria um sentido extraoficial à morte, como se fosse dizer -“ah, faz sentido agora, eram normalistas" -; e b) a participação de forças estatais nos eventos de violência, dessa vez como cumplices e braço armado de um cartel, situação reconhecida pelo governo federal através da PGR, no entanto, curiosa e convenientemente limitado ao nível municipal sem involucrar às forças militares e federais e, em conjunto, com funcionários públicos envolvidos no

\footnotetext{
${ }^{253}$ Informe Ayotzinapa I, pág. 36.

254 "Karam explicó que hasta el momento han sido localizadas 9 fosas, con un total de 30 cadáveres que según los informes preliminares no pertenecen a ninguno de los 43 estudiantes de la escuela magisterial de Ayotzinapa, desaparecidos el 26 de septiembre. Un equipo de antropología forense argentino está realizando un segundo estudio sobre los restos." - El alcalde de iguala ordenó el ataque contra los normalistas de Ayotzinapa: PGR Paola ALÍN em Animal Político, disponível em: http://www.animalpolitico.com/2014/10/la-pgr-confirma-que-elalcalde-de-iguala-ordeno-el-secuestro-de-los-estudiantes-de-ayotzinapa/ - publicado em 23 de outubro de 2014 , acessado em maio de 2016.

255 “La razón de la desaparición, según la consignación elaborada por la PGR, hubiera sido que había miembros del grupo criminal "Los Rojos” infiltrados entre los estudiantes: 'para posteriormente entregar a los cuarenta y tres a miembros de la organización criminal denominada 'Guerreros Unidos', con quienes el cuerpo de seguridad pública de dicho municipio, mantiene nexos (...).” Informe Ayotzinapa I, pág: 181.

${ }^{256}$ Ídem, pág. 179.
} 
narcotráfico, igualmente limitado apenas ao nível municipal ${ }^{257}$. O GIEI levantará a questão da participação do Exército e da Polícia Federal posteriormente.

Finalmente, a PGR, segundo o relatado pelo GIEI no Informe Ayotzinapa I ${ }^{258}$ contava com quatro linhas de investigação sobre o destino final dos 43 normalistas para posteriormente acrescentar uma quinta teoria: 1) Pueblo Viejo: os normalistas teriam sido levados ao bairro de Pueblo Viejo na mesma cidade de Iguala. Os estudantes teriam sido alguns assassinados com armas de fogo e outros calcinados vivos. A versão apresenta inconsistências entre os depoimentos dos suspeitos em matéria de discordância de horas de acontecimentos e a data dos assassinatos, assim como versões que indicam que os normalistas estavam armados e que teriam tentado roubar carros, embora não existam registros do anterior ${ }^{259}$; 2) Las Lomas: os estudantes teriam sido assassinados em uma casa de segurança pelos Guerreros Unidos. Os depoimentos mencionam de novo aos normalistas armados e, dos 43 desaparecidos, apenas 17 teriam sido assassinados pelo cartel $^{260}$; 3) Los Peques: é provavelmente a versão mais inverossímil já que os depoimentos indicam que os normalistas teriam chegado em Iguala para assassinar aos donos do lava-jato "Los Peques". As discordâncias começam quando asseguram que os normalistas chegaram em Iguala sete horas antes do reportado pelo C-4, continua com a suposição de que 17 membros do cartel rival Los Rojos estariam infiltrados entre os estudantes, os quais foram capturados e calcinados. Praticamente nenhum acontecimento relatado concorda com as evidencias tanto do GIEI como da própria PGR ${ }^{261}$; e 4) El Gil: o depoimento de "El Gil", testemunha detida e suposto integrante de Guerreros Unidos, aporta unicamente a versão de que os estudantes foram divididos em dois grupos: um foi destinado a Cocula e o outro a um rancho propriedade do cartel onde foram "cocinados y hechos agua". A testemunha não aprofundou na declaração e demonstrava sinais de tortura ${ }^{262}$.

A quinta e última linha de investigação sobre o destino final dos normalistas seria a privilegiada pela PGR e por Jesús Murillo Karam para elaborar e divulgar, no dia 7 de novembro de $2014^{263}$, o que chamaria de "Verdade Histórica": Após os normalistas terem sido confundidos com

\footnotetext{
${ }^{257}$ Enquanto José Luis Abarca e a sua esposa foram sujeitos de uma caça humana, o governador de Guerrero, Ángel Aguirre ou funcionários de mais alto nível não foram investigados.

258 4. Versiones sobre el destino de los 43 estudiantes desaparecidos - Informe Ayotzinapa I, pág. 127.

${ }^{259}$ Ídem, pág. 129-130.

260 Ídem, pág. 132-133.

261 Ídem, pág. 142-143.

262 Informe Ayotzinapa II: pág. 255.

${ }^{263}$ Vídeo da conferência de imprensa de Jesús Murillo Karam disponível através de YouTube no canal do Gobierno de la República - Conferencia de Prensa del Procurador, Jesús Murillo Karam (Ayotzinapa), disponível em: https://youtu.be/QNcfdHUiP8c - publicado em 7 de novembro de 2014, acessado em maio de 2016.
} 
integrantes de Los Rojos, os policiais municipais tanto de Iguala como de Cocula, em colusão com os Guerreros Unidos e sob as ordens do prefeito José Luis Abarca, involucrado com este último cartel, teriam atacado os ônibus dos normalistas para posteriormente levar com eles aos 43 desaparecidos. O destino foi: 5) o lixão de Cocula: os normalistas seriam trasladados em duas camionetes para o lixão. No momento da chegada, 15 estudantes teriam falecido ao serem esmagados pelo peso dos companheiros dentro das camionetes. Os depoimentos sobre o assassinato dos estudantes apresentam inconsistências, como praticamente todas as versões explicitadas até este momento, desde declarações que indicam que foram assassinados com tiros na cabeça, com golpes de troncos ou uma mistura de ambos, até versões que estabelecem que todos foram assassinados na parte alta do lixão ou na parte baixa, ou ambos. Em seguida, na parte baixa do lixão, os corpos seriam incinerados com galhos, lenha, pneus, diesel e gasolina para finalmente recolher os restos em sacolas plásticas e jogá-los no Rio San Juan.

O anterior é a "verdade histórica" com a qual o titular da PGR, Jesús Murillo Karam, tentou arquivar o caso de Ayotzinapa como uma disputa entre cartéis que derivou em uma "confusão" facilitada pela infiltração do narcotráfico apenas na escala municipal da administração política do território e exonerar ao Estado mexicano, ao exército e à Polícia Federal no processo. As inconsistências e omissões encontradas pelo GIEI levantam suspeitas sobre a participação de forças militares e federais seguindo uma cadeia de comando semelhante à vista no caso Tlatlaya sobre a possível premeditação do ataque contra um grupo dissidente, justificando-o como um confronto a mais entre traficantes no marco da guerra contra as drogas.

A continuação se explicitarão os fatos levantados e as inconsistências na investigação oficial encontradas pelo GIEI que derrubam a "verdade histórica", principalmente: a) a impossibilidade física de incinerar 43 corpos nas circunstâncias descritas; b) a participação da Policía Federal; c) a participação do $27^{\circ}$ Batalhão de Iguala; d) as graves omissões de Jesús Murillo Karam como titular da PGR; e e) as visitas clandestinas de Tomás Zerón de Lucio ao lixão de Cocula e ao Rio San Juan. 


\section{A "verdade histórica" derrubada}

O GIEI, como grupo independente de investigação criado pela Comissão Interamericana de Direitos Humanos - CIDH à expressa solicitação do Estado mexicano de assistência técnica na busca pelos 43 normalistas, foi encomendado com a missão de adotar as medidas necessárias para determinar a localização dos estudantes. Umas das suas atribuições e garantias, explicitadas nos pontos 5.1, 5.2, 6.1 e 9 do acordo para a incorporação de assistência técnica internacional assinado por representantes do Estado mexicano, familiares das vítimas, da CIDH e da $\mathrm{OEA}^{264}$, estabelecem que: a) o GIEI se compromete a analisar se a investigação da PGR realizou toda as ações necessárias e se implementou todos os dispositivos e protocolos das instituições federais para localizar aos estudantes; b) assim como realizar informes e recomendações para melhorar o plano de busca se assim for necessário; c) para o anterior, o Estado garantirá acesso total aos expedientes das investigações e informação pública governamental, instalações, infraestrutura, recursos e segurança.

A continuação se analisarão alguns pontos principais que, levantados pelo GIEI seguindo os compromissos e obrigações acima explicitados, contribuíram à desconstrução da "verdade histórica" da PGR, assim como a violação das garantias outorgadas ao grupo por parte do Estado mexicano.

A primeira discordância que os Informes Ayotzinapa I e II do GIEI encontram na "verdade histórica" da PGR é a suposta não participação da Policía Federal e do Exército nos ataques em Iguala, versão que Murillo Karam e o general Salvador Cienfuegos defenderam veementemente. $\mathrm{O}$ informado pelo GIEI, contrariamente, fortalece a versão da participação direta ou indireta da $\mathrm{PF}$ e do $27^{\circ}$ Batalhão de Iguala.

Referente à participação da PF, o informe detalha que alguns comportamentos abnormais e suspeitos dos policiais que foram ignorados pela PGR devem ser investigados, tais como: a) o motivo pelo qual o bloqueio e desvio de automóveis estabelecido fora da cidade de Iguala deixou passar ao ônibus do time de Los Avispones que seria atacado mais adiante; b) a presença

\footnotetext{
264 Acuerdo para la incorporación de asistencia técnica internacional desde la perspectiva de los derechos humanos en la investigación de la desaparición forzada de 43 estudiantes de la Normal Rural Raúl Isidro Burgos de Ayotzinapa, Guerrero, dentro de las medidas cautelares MC/409/14 y en el marco de las facultades de monitoreo que la CIDH ejerce sobre la situación de los derechos humanos en la región - Documento disponível online através do site do GIEI - http://prensagieiayotzi.wix.com/giei-ayotzinapa - acessado em maio de 2016.
} 
de viaturas da PF no ataque a um dos ônibus de normalistas no qual viajavam alguns dos desaparecidos; e c) a ausência e demora para atender aos feridos no ataque ao ônibus do time Los Avispones e automóveis particulares, sendo que o bloqueio da PF estava perto ${ }^{265}$.

A suposta participação do $27^{\circ}$ Batalhão de Iguala provoca ainda mais suspeitas devido à participação de elementos castrenses em anteriores ataques à população (como Tlatlaya ou Ostula). O Informe Ayotzinapa I relata a presença de elementos castrenses como observadores nos ataques, particularmente frente ao Palácio de Justiça no qual estudantes foram abduzidos, assim como a sua inatividade durante a noite dos ataques sendo que a base do $27^{\circ}$ Batalhão está localizada dentro da cidade de Iguala. Além do mais, a informação recebida desde o C-4 era em tempo real e os militares sabiam em todo momento que os ataques eram contra normalistas de Ayotzinapa ${ }^{266}$. Posteriormente, se relata a visita de militares ao hospital no qual se encontravam alguns normalistas feridos e outros refugiados. As declarações dos soldados diferem radicalmente das declarações dos estudantes: a) não foram registrados - foram registrados sem camisa; b) chamado imediato à ambulância para atender aos feridos - não houve atendimento nem chamado à ambulância; c) não lhes retiraram pertences e podiam atender ligações - os pertences foram retirados e as ligações proibidas; d) tratados com respeito sem uso ostensivo das armas - foram ameaçados com armas e insultados; e) não foram identificados pelos nomes - os nomes dos estudantes foram registrados; e f) apenas duas fotografias foram tomadas - várias fotografias foram tomadas ${ }^{267}$.

Em paralelo lembra que o C-4 repassa a informação recebida para distintas corporações policiais, tanto municipais e estatais, mas também para a PF e para o Exército Mexicano. Portanto, o GIEI aponta que tanto os militares como os federais tinham conhecimento dos acontecimentos desde o momento em que os estudantes saíram de Chilpancingo rumo a Iguala $^{268}$.

O informe estabelece uma serie questionamentos que, afirmam "[...] eran parte de las preguntas que el GIEI deseaba hacer a los miembros del $27^{\circ}$ Batallón e son parte de las indagaciones que hasta hoy no ha realizado la PGR": 1) O Que fizeram com a informação do C-4?; 2) que ações urgentes tomaram?; 3) informaram nesse exato momento às autoridades mais altas do Estado?; 4) que instruções receberam?; 5) caso contrário, por que não

\footnotetext{
${ }^{265}$ Informe Ayotzinapa II, pág. 114-115.

266 Ídem, pág. 124-125.

267 Ídem, pág. 133.

268 Ídem, pág. 121.
} 
informaram?; e 6) por que manipularam informação restringida no C-4 essa noite? ${ }^{269}$. O motivo de não ter resposta para essas perguntas que o GIEI considera vitais para não clausurar arbitrariamente linhas viáveis de investigação, de acordo ao compromisso do GIEI e as garantias que o Estado mexicano outorgaria no documento assinado, é a rotunda negativa do general Cienfuegos de permitir que os militares sejam interrogados ${ }^{270}$, com a complacência de Murillo Karam ${ }^{271}$.

A suposta participação do Exército e da PF é aprofundada ainda mais na investigação especial realizada por Anabel Hernández e Steve Fisher da Berkeley Graduate School of Journalism, University of California para a Revista Proceso ${ }^{272}$, ambos os autores afirmam que o ataque foi orquestrado e executado pela PF com a cumplicidade do Exército Mexicano como parte de um ataque premeditado para atingir a "[...] estructura ideológica y de gobierno de la institución (a Escola Normal)" já que pelo menos 11 dos 43 desaparecidos formavam parte de distintos comitês de luta e formação política e ideológica ${ }^{273}$

A investigação faz ênfase no funcionamento e papel do C-4, sistema que funciona através de câmeras e comunicação entre as distintas forças de segurança, exército e PF incluídos, e integra também chamadas e comunicações aos números de emergência como bombeiros e ambulâncias. O GIEI relata que na noite do ataque aos normalistas o C-4 encontrava-se sendo operado por militares ${ }^{274}$. O seguimento dos estudantes se deu através de avisos ao comandante da PF em Iguala e ressaltam a coordenação da presença de policiais federais para com a presença dos normalistas, especialmente o aviso às 21:22 horas sobre a chegada dos normalistas à rodoviária de Iguala e o começo do primeiro tiroteio 18 minutos depois ${ }^{275}$. Na investigação aparecem de novo relatos sobre o equipamento fora do comum que os policiais municipais que

\footnotetext{
${ }^{269}$ Informe Ayotzinapa I, pág. 194

270 “En entrevista para Noticieros Televisa, se preguntó: ‘¿qué quieren saber?’' ‘Que qué sabían los soldados? Está todo declarado, yo no puedo permitir que a los soldados los traten como criminales o los quieran interrogar para posteriormente hacer sentir que tienen algo que ver y no apoyarlos, esa es mi posición y de ahí no puedo ni debo salirme, porque perdería mucho de lo que soy', agregó". Redacción AN - "No voy a permitir que interroguen a mis soldados" por caso Ayotzinapa: Cienfuegos, em Aristegui Noticias, publicado em 6 de outubro de 2015, disponível em: http://aristeguinoticias.com/0610/mexico/no-voy-a-permitir-que-interroguen-a-missoldados-por-caso-ayotzinapa-cienfuegos/ - acessado em maio de 2016.

271 "No hay una sola evidencia de que haya intervenido el ejército, ni una sola." Conferência de imprensa do dia 27 de janeiro de 2015 - Vídeo disponível em YouTube através de: https://youtu.be/pwYMmh2V6nE - Frase selecionada a partir do minuto 1:07:20 - publicado em 27 de janeiro de 2015, acessado em maio de 2016.

272 Iguala: La historia no oficial - Anabel HERNÁNDEZ e Steve FISHER em Proceso, publicado em 13 de dezembro de 2104, disponível em: http://www.proceso.com.mx/390560 - acessado em maio de 2016.

273 Ídem.

${ }^{274}$ Informe Ayotzinapa II, pág. 122.

275 "A las 21:22 horas el jefe de la base de la PF, Luis Antonio Dorantes, fue informado de la entrada de los jóvenes a la central camionera y a las 21:40 el C-4 de Iguala reportó el primer tiroteo" - Iguala: La historia no oficial. Op. Cit.
} 
atacaram os ônibus utilizavam, assim como a acusação direta de estudantes sobre agentes da PF que atiraram em conjunto com os policiais municipais ${ }^{276}$. Finalmente, ao relatar o evento da visita dos militares ao hospital que o GIEI levantou por sua vez, as testemunhas e os investigadores fazem ênfase na fala dos soldados enquanto se entrevistavam com os estudantes refugiados, especialmente ao momento de pedir os nomes de cada um:

$$
\begin{aligned}
& \text { “'- No quiero que me den nombres falsos porque si me dan un nombre falso, } \\
& \text { nunca los van a encontrar - Eso así lo dijo, textualmente' afirma Omar. } \\
& \text { 'Estaban insinuando que nos iban a desaparecer o que seriamos detenidos en } \\
& \text { algún lugar”277 }
\end{aligned}
$$

As evidências e testemunhas levantadas pelo GIEI e pelos investigadores independentes da Universidade de Califórnia se somam a outros vícios presentes na investigação elaborada pela PGR. Murillo Karam foi criticado duramente por ter levado a cabo uma investigação que parecia mais uma série de acontecimentos selecionados propositalmente para elaborar uma versão confortável para o governo federal, porém, o funcionário cometeu crassos erros procedimentais que viciaram a investigação de origem. É assim que o analisa Layda Negrete ${ }^{278}$ ao identificar três vícios na investigação atribuíveis ao titular da dependência:

1) Violação da presunção de vida: aponta que desde os primeiros momentos em que a PGR assumiu as investigações do caso Ayotzinapa, a postura do titular da PGR foi a de buscar 43 cadáveres. Esta postura condicionou, por consequência, os protocolos e técnicas utilizadas na investigação e busca dos sujeitos em questão já que as tecnologias e procedimentos para buscar a uma pessoa sequestrada diferem radicalmente das ferramentas utilizadas em investigações de homicídio, assim como a disponibilidade de recursos e faculdades legais. Durante os primeiros momentos da investigação, a única evidência da suposta morte dos normalistas emanava dos depoimentos dos suspeitos detidos e interrogados e que, como foi exposto acima e no Informe Ayotzinapa I, os depoimentos dos suspeitos em relação à morte dos estudantes têm discordâncias entre eles. Por outro lado, uma pessoa vítima de uma desaparição forçada deve ser considerada precisamente como -desaparecida- e não como falecida. A presunção de vida está consagrada pela ONU como uma obrigação processual no documento da Convenção

\footnotetext{
276 “(...) afirman que algunos atacantes estaban equipados con pecheras, rodilleras, cascos, coderas y pasamontañas y una patrulla traía soporte para ametralladora (...) se investigó que la policía municipal de Iguala no usa este equipo (...) llegaron elementos de la Policía Federal y ellos fueron los que dispararon en contra de mis compañeros, hiriendo a varios de éstos, y resultó muerto uno de ellos (...) Uno de los videos revisados por los reporteros demuestra que entre los atacantes sí había agentes de la PF." Ídem.

${ }^{277}$ Ídem.

${ }^{278}$ Murillo Karam: juicio político - Layda NEGRETE em Horizontal, publicado em 21 de setembro de 2015, disponível em: http://horizontal.mx/murillo-karam-juicio-politico/ - acessado em maio de 2016.
} 
Internacional para a Proteção de Todas as Pessoas da Desaparição Forçada ${ }^{279}$ no seu artigo $24^{\circ}$ $16^{280}$.

2) Exoneração do Exército e da PF: Neste sentido, a possível participação do $27^{\circ}$ Batalhão de Iguala e de elementos da PF no ataque aos normalistas como uma ação premeditada e planejada foi imediatamente descartada pelo titular da PGR, embora os Informes Ayotzinapa I e II tenham apontado evidência que apontava à participação de forças federais junto com a investigação independente de Anabel Hernández e Steve Fisher. Diante dos questionamentos sobre a passividade do Exército durante os ataques e o seguimento que tinha sido dado aos estudantes desde o C-4, Murillo Karam limitou-se a responder que não houve ordens para os soldados defenderem aos estudantes e, caso tivessem agido, teria sido contra os próprios normalistas ${ }^{281}$. Posteriormente, junto com o general Cienfuegos, se opôs absolutamente a permitir que a busca pelos normalistas se realizasse nas bases militares da região argumentando que havia certeza que não estariam ali ${ }^{282}$. De esta forma, uma linha de investigação viável foi bloqueada de raiz pelo titular da PGR e, segundo aponta Negrete, pode não ser considerado como um erro inocente ou de incompetência, senão que de acordo ao documento da Convenção da ONU acima referenciado nos seus artigos $2^{\circ}$ e $6^{\circ} / 1$-b-i e iii, pode configurar a facilitação da materialização da desaparição forçada através das instituições do Estado e agentes do mesmo e, portanto, Murillo Karam e o general Cienfuegos teriam sido participes e sujeitos de processo penal ${ }^{283}$.

\footnotetext{
${ }^{279}$ International Convention for the Protection of All Persons from Enforced Disappearance-Resolution adopted by the General Assembly - 12 janeiro de 2007 - Disponível em: http://w02.unssc.org/free_resources/UNDPOHCHRToolkit/pdf/61.177.pdf - acessado em maio de 2016.

${ }^{280}$ Art. $24^{\circ}$ / 6: "Without prejudice to the obligation to continue the investigation until the fate of the disappeared person has been clarified, each State Party shall take the appropriate steps with regard to the legal situation of disappeared persons whose fate has not been clarified and that of their relatives, in fields such as social welfare, financial matters, family law and property rights." Ídem.

281 “(...) Jesús Murillo Karam, justificó: 'El Ejército se mueve sólo con órdenes. ¿Qué hubiera pasado si hubiera salido? ¿A quién hubiera apoyado? Obviamente a la autoridad. ¿Qué bueno que no salió!'”-Inacción militar que olió a complicidad - Marcela TURATI em Proceso, publicado em 8 de novembro de 2014, disponível em: http://www.proceso.com.mx/387136/inaccion-militar-que-olio-a-complicidad - acessado em maio de 2016.

282 "El Procurador General de la República, Jesús Murillo Karam dijo que el gobierno no buscará en bases militares a los 43 normalistas desaparecidos, porque 'sabemos que no están ahi' y señaló que es 'absurdo' suponerlo. " - Murillo considera "absurdo" buscar a normalistas en bases militares - Marcela TURATI em Proceso, publicado em 4 de dezembdo de 2014, disponível em: http://www.proceso.com.mx/389808/murilloconsidera-absurdo-buscar-a-normalistas-en-bases-militares - acessado em maio de 2016.

${ }^{283} \mathrm{O}$ documento define Desaparição Forçada no art. $2^{\circ}$ como a “ (...) detenção, abdução ou outra forma de privação da liberdade por agentes do Estado o por pessoas o grupos agindo com autorização, suporte ou reconhecimento do Estado (...)”; posteriormente no art. 6\%1-i e iii considera criminalmente responsáveis a: “(b) Um superior que [...] (i) Saiba, ou conscientemente desconsidere informação que claramente indicava que subordinados sob a sua autoridade efetiva e controle estejam cometendo ou cometerão o crime de desaparição forçada. (iii) Falhem ao tomar todas as medidas necessárias e razoáveis ao alcance do seu poder para prevenir ou reprimir a desaparição forçada o submeter o assunto às autoridades competentes para a acusação e investigação. "
} 
3) Condenação sem julgamento prévio dos suspeitos interrogados: Finalmente, o titular da PGR violou a presunção de inocência dos suspeitos interrogados ao declarar, na conferência de imprensa na qual divulgou a "verdade histórica" ${ }^{284}$, que três das pessoas detidas eram integrantes do cartel dos Guerreros Unidos e eram responsáveis pelo assassinato dos 43 normalistas. Situação que Negrete considera preocupante já que o funcionário “[...] exhibió como culpables, ante los medios de comunicación, a personas que no habían sido condenadas por un juez; mostró sus caras, pronunció sus nombres, les atribuyó hechos y les dictó sentencia" seguindo um discurso estruturado como monologo no qual "[...] no se presentó abogado defensor o juez. No hubo juicio, pero sí hubo culpables. "285 Não está demais lembrar que o Procurador Geral da República carece de atribuições legais para julgar suspeitos os quais, vale a pena relembrar, produziram depoimentos muito variáveis entre eles e dos quais foram selecionados os que menos discordâncias apresentaram para fabricar a versão considerada como "verdade histórica".

O ponto fraco mais escandaloso e criticado da "verdade histórica" de Murillo Karam foi a suposta incineração dos corpos dos 43 normalistas no lixão de Cocula utilizando apenas lenha, pneus, diesel e gasolina para posteriormente os restos serem jogados em sacolas plásticas no Rio San Juan. Uma sacola utilizada seria recuperada pelas agências de investigação em circunstâncias abnormais que serão explicadas posteriormente e análises periciais de DNA por parte da Universidade de Innsbruck demonstrariam que os restos pertencem a dois normalistas que se encontravam entre os 43 desaparecidos. No entanto, o fato da PGR tentar construir a teoria da queima massiva a partir dos restos de apenas um estudante resulta frágil para todo propósito.

Na conferência de imprensa do dia 7 de novembro de $2014^{286}$ o titular da PGR afirma que os suspeitos confessaram ter queimado os corpos. O fogo teria durado mais de 14 horas segundo o declarado por Murillo Karam, os fragmentos ósseos seriam fraturados e recolhidos junto com as cinzas. A investigação do GIEI se centrou nos fatores que seriam necessários para reduzir a cinzas aos 43 corpos dos estudantes nas condições em que supostamente aconteceram os relatos da PGR e dos suspeitos. No Informe Ayotzinapa I se estabelece que um corpo humano adulto precisaria de uma temperatura de $800-1000^{\circ} \mathrm{C}$ durante $90-120$ minutos para ser reduzido a

\footnotetext{
284 Vídeo- Conferencia de Prensa del Procurador, Jesús Murillo Karam (Ayotzinapa), publicado em 7 de novembro de 2014, disponível em: https://youtu.be/QNcfdHUiP8c - frase selecionada a partir do minuto 2:30 ${ }^{285}$ Murillo Karam: juicio político - Layda NEGRETE. Op.Cit.

286 Vídeo- Conferencia de Prensa del Procurador, Jesús Murillo Karam (Ayotzinapa), disponível em: https://youtu.be/QNcfdHUiP8c - Minuto 11:50
} 
cinzas, isto em um forno de crematório o qual fornece as condições mais eficientes ${ }^{287}$, condições que evidentemente não se encontrariam em um lixão ao ar livre. A seguinte conclusão do GIEI é lapidaria para a teoria da PGR:

\footnotetext{
"Asumiendo que la combustión no se extingue - algo que el perito (Dr. José Torero) dice que es muy probable (...) - se puede calcular que, en estas condiciones de quemado, es necesario entre 20.000 y $40.000 \mathrm{Kg}$ de madera o entre 9.000 y $18.000 \mathrm{~kg}$ de llantas para consumir un cuerpo" Informe Ayotzinapa I, pág. 147.
}

Em conferência de imprensa no dia 27 de janeiro de 2015, em conjunto com Tomás Zerón de Lucio, titular da AIC, Murillo Karam afirmou que “ [...] las llantas utilizadas alcanzaron hasta $1600^{\circ} \mathrm{C}$ dificultando que el fuego se extinguiera por medios mecánicos y prolongando su conflagración $^{288}$ ", isto é, com 10 ou 15 pneus e lenha ${ }^{289}$ conseguiram atingir uma temperatura $385^{\circ} \mathrm{C}$ a mais da necessária para fundir o granito ${ }^{290}$.

Outra fraqueza na teoria da PGR sobre a queima no lixão é a quantidade de radiação calorífica que seria produzida pela queima, além da chama de 7 metros e a muito visível coluna de fumaça de 300 metros $^{291}$. A perícia do GIEI estabelece, dentro do lixão de Cocula, três perímetros circulares a partir da origem do fogo: a partir do centro, o primeiro círculo teria uma radiação calorífica de $16 \mathrm{~kW} / \mathrm{m} 2^{292}$; 15 metros depois a radiação desceria a $4 \mathrm{~kW} / \mathrm{m} 2$ e a 30 metros do centro haveriam $2 \mathrm{~kW} / \mathrm{m} 2$. Esta última quantidade de radiação calorífica corresponde ao limite de dor que uma pessoa pode tolerar e que é capaz de gerar danos na pele e é, portanto, impossível para uma pessoa se expor a essa temperatura. Sendo que a quantidade $2 \mathrm{~kW} / \mathrm{m} 2$ era perceptível a 30-50 metros do fogo, teria sido " [...] imposible descender a la hondonada del basurero y definitivamente imposible atizar el fuego" 293 como os depoimentos das testemunhas da PGR afirmam que aconteceu.

O GIEI apresenta sete conclusões iniciais sobre a versão da queima no lixão de Cocula: 1) não há evidência que sustente a hipótese da queima de 43 corpos no lixão; 2) toda evidência

\footnotetext{
${ }^{287}$ Informe Ayotzinapa I, pág. 146.

288 Vídeo - Iguala Informe PGR 27 Enero 2015 - Dísponivel em YouTube através de: https://youtu.be/pwYMmh2V6nE - Frase selecionada a partir do minuto 12:15 - acessado em maio de 2016.

289 “(...) Miguel Landa Bahena indica que usaron como 10 a 15 neumáticos y el resto fue completado con madera." Informe Ayotzinapa I, pág. 148.

290 “Basalt melts at about $984^{\circ}$ to $1260^{\circ}$ and granite at about $1215^{\circ}$ to $1260^{\circ}$." Esper S. LARSEN - The Temperatures of Magmas - Harvard University - American Mineralogist, disponível em: http://www.minsocam.org/msa/collectors_corner/arc/tempmagmas.htm - acessado em maio de 2016.

${ }^{291}$ Informe Ayotzinapa I, pág. 149.

${ }^{292}$ Kilowatt sobre metro quadrado.

${ }^{293}$ Informe Ayotzinapa I, pág. 150 - 151.
} 
demonstra que houve apenas fogo de pequenas dimensões sem temporalidade definida; 3) toda evidência demonstra que o mínimo incêndio necessário para a cremação dos corpos não podia acontecer no lixão e, de haver existido, haveriam danos visíveis na vegetação e no lixo; 4) Não é possível estabelecer se os incêndios no lixão foram de dimensões suficientes para incinerar um ou mais corpos, mas não há evidência da presença de fogo suficiente para queimar apenas um corpo; 5) não há evidência da disponibilidade do combustível necessário para a cremação dos corpos nas proximidades do lixão; 6) as testemunhas relatam eventos que não seriam possíveis com as condições geradas pelo fogo necessário para consumir 43 cadáveres; e 7) os estudos da PGR foram limitados técnica e cientificamente e, por tanto, as conclusões são maioritariamente erradas e não emergem da evidência material e da sua possível interpretação ${ }^{294}$. Em paralelo, a EAAF declarou, via comunicado, que conclui impossível a versão da queima no lixão ao não encontrar consistência entre a evidência física e os fatos científicos, assim como as discordâncias nos depoimentos das testemunhas ${ }^{295}$.

Pelo anterior, a investigação da PGR que levou à promulgação da "verdade histórica" não foi apenas fraca e cheia de inconsistências tanto nas declarações dos supostos culpáveis como nas evidências apresentadas sob uma máscara de cientificidade, senão que o próprio proceder da dependência e dos seus titulares e agentes gera suspeitas sobre a possível fabricação de cenários ao redor do lixão de Cocula. A personagem central nas pericias realizadas no lixão é Tomás Zerón de Lucio, titular da AIC e aliado político de Enrique Peña Nieto desde os tempos do governo no Estado de México. O anterior foi evidenciado em ambos os Informes do GIEI ao aprofundar no cenário do Rio San Juan, lugar onde supostamente as cinzas e restos ósseos dos estudantes foram jogados. Os depoimentos das testemunhas da PGR, recolhidos pelo GIEI, novamente apresentam inconsistências temporais já que os interrogados se contradizem nas datas em que as cinzas e restos foram recolhidos e jogados no rio $^{296}$.

Após uma chamada telefônica anônima no dia 26 de outubro de 2014, a PGR recebeu informação de que os restos dos normalistas teriam sido jogados no Rio San Juan ${ }^{297}$. No dia 29

\footnotetext{
${ }^{294}$ Informe Ayotzinapa I, pag. 331.

295 “(...) el EAAF ha concluido que desde el punto de vista de la evidencia recolectada y analizada proveniente del basurero NO es posible que los presuntos perpetradores hayan incinerado en ese lugar a los 43 jóvenes, pues NO hay consistencia entre la evidencia fisica y la evidencia testimonial." Equipo Argentino de Antropología Forense (EAAF) presenta peritaje sobre caso Ayotzinapa; confirma la imposibilidad científica de la "verdad histórica" oficial - Disponível através do portal oficial da EAAF em: http://www.eaaf.org/files/boletin-eaaf---9de-febrero-de-2016.pdf - publicado em 9 de fevereiro de 2016, acessado em maio de 2016. Grifos do autor.

296 "Es decir, todos los que habrían participado en esos hechos refieren momentos diferentes. Para dos de ellos las 'cenizas' que habrían quedado las recogieron el mismo día 27, mientras para otros dos las habrían ido a recoger un día después (...).” Informe Ayotzinapa I, pág. 141.

${ }^{297}$ Informe Ayotzinapa II, pág. 289.
} 
de outubro de 2014, elementos da Marinha mexicana encontraram uma sacola plástica no rio mencionado. No interior encontravam-se restos humanos calcinados. Elementos do EAAF realizaram as provas periciais de DNA correspondentes que derivaram na confirmação da identidade de Alexander Mora Venancio, de 19 anos, um dos 43 normalistas desaparecidos ${ }^{298}$. Posteriormente os restos seriam enviados ao laboratório da Universidade de Innsbruck o qual confirmaria os resultados do EAAF e posteriormente identificaria um segundo normalista, Jhosivani Guerrero de la Cruz, de 20 anos de idade ${ }^{299}$.

A primeira inconsistência levantada foi da própria EAAF ao denunciar, mediante um comunicado, que não foram testemunhas da descoberta da sacola plástica ao não estar presentes no Rio San Juan na manhã do dia 29 de outubro, dia que a PGR afirma ter encontrado a evidência. Acrescentam que tampouco foram testemunhas no momento em que a sacola foi aberta para encontrar os restos ${ }^{300}$, em particular os que deram identificação positiva dos dois estudantes e, finalizam, que não existem registros oficiais sobre a cadeia de custódia da evidência recuperada, constando apenas o fato de que foi encontrada por um mergulhador da Marinha $^{301}$.

Posteriormente, o GIEI revelaria uma série de eventos encabeçados por Tomás Zerón de Lucio. Embora oficialmente a primeira diligência da PGR no rio com a ajuda de dois suspeitos tenha sido levada a cabo na manhã do dia 29 de outubro, dia em que os restos foram descobertos, o

\footnotetext{
298 "Los resultados confirman la identificación de Alexander Mora Venancio, uno de los 43 estudiantes desaparecidos (...)." - Forenses argentinos: no hay pruebas de que los restos de Mora provinieran del basurero, disponível em: http://www.jornada.unam.mx/2014/12/08/politica/004n1pol - Redacción La Jornada, publicado em 8 de dezembro de 2014, acessado em maio de 2016.

299 "Se trata del estudiante Jhosivani Guerrero de la Cruz, confirmó en conferencia de prensa la procuradora Arely Gómez. Lo especialistas de Innsbruck ya habían logrado identificar los restos del estudiante Alexander Mora Venancio." - Identifican en Innsbruck a otro de los 43 - Redacción AN em Aristegui Noticias, publicado em 16 de setembro de 2015, disponível em: http://aristeguinoticias.com/1609/mexico/identifican-en-innsbruck-asegundo-normalista-de-ayotzinapa-pgr/ - acessado em maio de 2016.

300 "El EAAF no estuvo presente en el momento en que buzos y peritos de la PGR recuperaron dicha bolsa ni participó en el hallazgo de dicho fragmento. El EAAF fue convocado por la PGR al lugar cuando ya se encontraba la bolsa de restos abierta y la muestra en cuestión ya se encontraba junto con otra sobre un área de limpieza." Comunicado do dia 07 de dezembro de 2014 - Identificación de uno de los 43 normalistas desaparecidos de Ayotzinapa - Dísponivel através do portal oficial do EAAF em:

http://www.eaaf.org/files/comunicado-de-prensa eaaf_07diciembre2014.pdf - acessado em maio de 2016.

301 “Así mismo, el EAAF solicitó en reiteradas oportunidades a la PGR la cadena de custodia correspondiente al hallazgo de dicha bolsa, contando hasta la fecha sólo con un acta emitida por el Ministerio Público que señala que el 29 de octubre de 2014, buzos de la Marina le hicieron entrega de dicha bolsa." Comunicado do dia 28 de abril de 2016 - Disponível no portal oficial do Centro PRODH em: http://www.centroprodh.org.mx/index.php?option=com_content\&view=article\&id=1833\%3A2016-04-28-23-32-

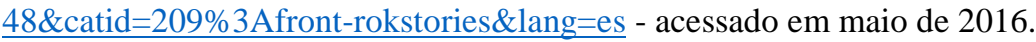


GIEI apresenta no Informe Ayotzinapa II evidência através de um vídeo da própria PGR ${ }^{302}$ no qual aparecem imagens de diligências prévias extraoficiais no lugar da descoberta dos restos por parte de elementos da dependência, suspeitos e do próprio Tomás Zerón nos dias 27 e 28 de outubro, diligências nas quais, aponta o Informe, se recolheram amostras do lugar e houve uma preparação do cenário para a -futura- descoberta ${ }^{303}$.

Das imagens que aparecem no vídeo mencionado é importante considerar: 1) A presença de Tomás Zerón (minutos 0:40 e 1:13); 2) O bloqueio da estrada que leva à zona do Rio San Juan por parte de veículos da PGR (minuto 1:20) e a chegada do EAAF (minuto 2:26) que confirma o acontecimento em um comunicado ao afirmar que no dia 28 de outubro foram detidos nas proximidades do rio sem receber explicações e ratifica o explicitado pelo $\mathrm{GIEI}^{304}$; e 3) a imagem de um homem com sobretudo branco recolhendo amostras do chão (minuto 1:28).

As provas fornecidas pelo GIEI resultam importantes ao considerar as inconsistências que já vinham acontecendo com a investigação da PGR desde o primeiro momento. Apontam a diligências clandestinas, produto de uma chamada telefônica anônima, das quais não existe registro oficial nenhum, porém, no vídeo aparece alguém recolhendo amostras do chão sem registro posterior do recolhido; o titular da Agencia de Investigación Criminal ao lado de um suspeito; o EAAF foi impedido de se aproximar do lugar sem explicação nenhuma e, ao voltar no dia seguinte, foram recebidos com uma sacola plástica recuperada do rio, previamente aberta sem a presença dos expertos argentinos e sem registros da cadeia de custódia da evidência recuperada; e o fato de que um dia depois fosse encontrada a sacola plástica no lugar exato das diligências clandestinas do dia anterior ${ }^{305}$.

O GIEI dá o tiro de misericórdia ao apresentar, no próprio vídeo da PGR, imagens da sacola que seria descoberta no dia seguinte com etiqueta de identificação do dia 28 de outubro

\footnotetext{
${ }^{302}$ Vídeo proporcionado pelo GIEI disponível em diversos canais de YouTube: https://youtu.be/zF2giTlbMIg - Na imagem é possível apreciar a data do dia 28 de outubro de 2014; publicado em 24 de abril de 2015, acessado em maio de 2016.

${ }^{303}$ Informe Ayotzinapa II, pág: 285 - 286.

304 “La tarde del 28 de octubre de 2014, al descender desde el Basurero de Cocula (...) los vehículos en los que viajaban peritos del EAAF y también perito de la PGR fueron detenidos por personal de seguridad indicando que no se podía pasar por el momento, sin mayor explicación." Comunicado do dia 28 de abril de 2016 - Disponível no portal oficial do Centro PRODH; Op.Cit.

305 Informe Ayotzinapa II, pág: 300-301.
} 
(minutos 4:23, 4:28, 4:35 e 4:52) assim como imagens de peritos da PGR com restos ósseos nas mãos (minutos 5:04 e 5:10) ${ }^{306}$.

As circunstâncias irregulares nas quais foram descoberto os restos no rio San Juan no dia 29 de outubro emanadas de uma chamada telefônica anônima cinco dias antes, as diligências clandestinas extraoficiais do dia 28, as imagens de manipulação de restos e a presença de uma sacola plástica muito semelhante daquela que seria descoberta no dia seguinte levantam dúvidas consideráveis sobre a provável fabricação intencional de evidências por parte da PGR para sustentar uma "verdade histórica" confortável ao Estado através de investigações que, como foi explicitado na presente dissertação, têm mais discordâncias, contradições, linhas de investigação bloqueadas e evidências ignoradas do que coerências e certezas. $\mathrm{O}$ caso foi evidentemente conduzido para mantê-lo confinado no nível municipal sem involucrar autoridades estatais, federais ou militares ${ }^{307}$. Ao mesmo tempo, os motivos do ataque aos normalistas e o posterior sumiço de 43 estudantes foi reduzido seja a uma confusão entre estudantes e traficantes ou à infiltração dos mesmos por parte de membros do cartel rival dos Guerreros Unidos, criminalizando-os e justificando as suas mortes como consequência natural de ser estudante normalista mergulhado na violência da periferia, mortes que já foram oficializadas pela "verdade histórica", embora exista apenas evidência forense do assassinato de dois dos 43 .

A "verdade histórica" divulgada ad nauseam pela PGR foi em grande parte orquestrada por Tomás Zerón de Lucio, personagem diretamente ligada ao governo de Enrique Peña Nieto desde que o anterior se desempenhava como governador do Estado de México. Zerón de Lucio conta com o antecedente de haver sido participe de uma investigação polêmica na época prépresidencial de Peña Nieto quando ocupava o cargo de Coordinador de Investigación y Análisis de la Procuraduría General de Justicia del Estado de México em conjunto com Alberto Bazbaz como procurador e Alfredo Castillo como subprocurador, esta última personagem tomará relevância no próximo apartado.

\footnotetext{
306 “(...) se vio en las imágenes de periodistas gráficos dos bolsas de las mismas características, una negra con restos carbonizados y una blanca cuyo contenido no puede verse, se encuentran al lado del Rio San Juan a las 15:32h del día 28 (...).” Informe Ayotzinapa II, pág: 301.

307 “Carlos Beristáin, uno de los integrantes del GIEI, dijo: "Está claro en la investigación del gobierno y versión oficial que había la intención de mantener el caso en el nivel municipal, en términos de responsabilidad. Pero revelamos la presencia de losa gentes estatales y federales en las escenas del crimen y, todavía más, que su participación implicaba responsabilidad." - El gobierno federal se enreda en sus mentiras - Jesús CANTÚ em Proceso, publicado em 5 de maio de 2016, disponível em: http://www.proceso.com.mx/439632/gobierno-seenreda-en-sus-mentiras - acessado em maio de 2016.
} 
O caso em questão é o de uma menina de 4 anos de idade com deficiência motriz e da fala, Paulette Gebara Farah, a qual desapareceu misteriosamente do apartamento onde morava em $2010^{308}$. O caso virou imediatamente um assunto nacional com a mobilização de recursos do então governador do Estado de México, Peña Nieto, e das agências de investigação estatais assim como da grande mídia. A linha de investigação preferida pelas autoridades e pelo show mediático que tinha sido criado ao redor do caso apontava para o sequestro da menor, embora as últimas hipóteses após a resolução do caso apontaram a um possível auto sequestro orquestrado pelos pais ${ }^{309}$.

O que chama a atenção no caso de Paulette é a intervenção de Zerón de Lucio no caso em matéria de aplicação de técnicas de investigação ${ }^{310}$ para localizar à menor a qual, da forma mais inverossímil e suspeita e após nove dias desaparecida, foi encontrada sem vida entre o colchão e a cama do seu próprio quarto, isto após o apartamento inteiro ter sido invadido durante mais de uma semana por dezenas de pessoas e cachorros farejadores ${ }^{311}$. Ninguém percebeu, nem a própria mãe que deu entrevistas sentada na cama debaixo da qual encontrava-se o cadáver da sua filha. A morte foi oficializada como acidente ${ }^{312}$.

Zerón de Lucio, capaz de oficializar a qualquer preço uma versão tão fantasiosa como a de Paulette, é acusado pelo GIEI de recorrer à tortura como método de obter os depoimentos necessários para fabricar as "verdades" desejadas segundo o roteiro necessário para manter ao Estado mexicano intocado e imaculado. O Informe Ayotzinapa II denuncia a tortura sofrida por 17 suspeitos pertencentes ao cartel dos Guerreros Unidos, à polícia municipal de Iguala e a de Cocula $^{313}$.

O informe aponta, principalmente, à aparição de "novas lesões" corporais nos suspeitos um dia após terem sido detidos por elementos da marinha. Como exemplo, o GIEI apresenta o caso de Agustín García Reyes “El Chereje”, indivíduo vinculado a Zerón de Lucio como o suspeito que o acompanhou durante a diligência clandestina no Rio San Juan. O primeiro informe médico

\footnotetext{
308 Ayotzinapa: El "fabricante" Tomás Zerón - Álvaro DELGADO em PROCESO, publicado em 25 de abril de 2016, disponível em: http://www.proceso.com.mx/438472/ayotzinapa-fabricante-tomas-zeron - acessado em maio de 2016.

${ }^{309}$ Caso Paulette, la coartada mediatica - Redacción Proceso em PROCESO, publicado em 13 de abril de 2010, disponível em: http://www.proceso.com.mx/107322/caso-paulette-la-coartada-mediatica

310 Ayotzinapa: El "fabricante" Tomás Zerón, Op. Cit.

311 Ídem.

312 "Repentinamente, el cuerpo sin vida de la niña de cuatro años fue encontrado entre el colchón y el mueble de la cama, un desenlace que nadie creyó. Castillo y Zerón determinaron, también, que la muerte fue consecuencia de un 'accidente', que tampoco nadie creyó. El caso Ayotzinapa, cuya fabricación es de la autoría de Zerón de Lucio, va en el mismo camino...". Ídem.

${ }^{313}$ Informe Ayotzinapa II, pág: 385.
} 
após a detenção do suspeito no dia 27 de outubro de 2014 registra uma lesão corporal. O segundo informe médico no dia seguinte, o dia que visitou junto com Zerón o rio, registra 30 lesões corporais ${ }^{314}$. Os outros casos analisados pelo GIEI seguem o mesmo padrão de lesões novas após a detenção dos indivíduos. De esta forma, as declarações e depoimentos dos detidos perdem validez como evidência no caso, além de levantar suspeitas pelo passado de Zerón de Lucio e a possível fabricação de cenários e culpáveis para favorecer uma linha de investigação específica que, além das dúvidas e inconsistências processuais e essenciais, como já foi explicitado, resultou confortável para o Estado mexicano.

\section{A outra verdade}

A versão mais sustentada pelo GIEI como o possível motivo dos acontecimentos gira em torno ao $5^{\circ}$ ônibus que teria sido tomado pelos normalistas e o qual foi excluído de qualquer linha de investigação da PGR. Trata-se de um ônibus o qual, na noite dos ataques, foi tomado pelos estudantes em conjunto com os outros ônibus para chegar na Cidade do México. Uma primeira versão da PGR apontava a que o ônibus mencionado teria sido depredado e destruído pelos normalistas, coisa que os depoimentos dos mesmos estudantes rejeitam e afirmam que saíram do veículo e fugiram após terem sido detidos por viaturas da PF, posteriormente, o ônibus teria abandonado a cidade ${ }^{315}$.

O GIEI denuncia que dito ônibus foi totalmente excluído da história oficial da PGR mesmo com depoimentos de estudantes e testemunhas e ressalta o fato de que foi o único ônibus que não foi atacado essa noite e que posteriormente, um ônibus diferente ao utilizado pelos normalistas tenha sido apresentado ao GIEI para realizar labores periciais, em conjunto com contradições entre os depoimentos dos normalistas e do motorista, assim como inconsistências nas folhas de registro em quanto a rotas e destino se refere ${ }^{316}$.

\footnotetext{
314 "Las evidencias médicas incluidas en el propio expediente muestran que las lesiones fueron producidas de forma secuencial y mientras se encontraba bajo custodia, correspondiendo con un alto grado de consistencia a lesiones producidas por malos tratos y tortura. ” Ídem, pág: 426.

315 Informe Ayotzinapa II, pág: 233-234.

${ }^{316}$ Informe Ayotzinapa I, pág: 323-324.
} 
A pergunta que resulta dos eventos relatados é: qual é o motivo da insistência da PGR de desaparecer esse ônibus em particular da "verdade histórica"? O GIEI elabora a primeira conclusão: a única circunstância possível que explica a desaparição do ônibus do relato oficial da PGR, os depoimentos opostos de normalistas e dois depoimentos contraditórios do motorista (um diante da PGR e outro mediante um manuscrito que confirma a versão dos estudantes ${ }^{317}$ ), a apresentação de um ônibus diferente como evidência e a documentação contraditória do destino e rota do ônibus é que "[...] dicho camión, sea um elemento central del caso ${ }^{318 ” . ~}$

O GIEI lembra e traz à discussão um elemento que foi ignorado, embora narcotraficantes estejam involucrados no caso Ayotzinapa. Este é um elemento importante que, como foi explicitado, não é necessariamente a essência do narcotráfico, mas sim a sua moeda de troca: a droga. A zona central do Estado de Guerrero onde estão localizadas as cidades de Iguala, Cocula e um pouco mais longe Chilpancingo, capital, zona vizinha à região de Tierra Caliente, é um caldeirão de tráfico de drogas e pequenos cartéis independentes, ex-braços armados de grandes cartéis já desarticulados, Guerreros Unidos e Los Rojos fazem parte. A cidade de Iguala, menciona o GIEI, é um ponto focal no tráfico de heroína, a qual é contrabandeada, entre outras formas, dentro dos ônibus de passageiros ${ }^{319}$, situação levantada pelo GIEI $^{320}$ através do Departamento de Justiça dos Estados Unidos no estado de Illinois que conta com denúncias e investigações ao respeito ${ }^{321}$.

De acordo com: 1) o conhecimento coordenado da situação e do movimento dos estudantes que as autoridades tinham na noite dos ataques; e 2) o nível de violência e hostilidade dos ataques generalizados contra estudantes desarmados e em trânsito por Iguala rumo à Cidade do México, em conjunto com o time de futebol Los Avispones, confundidos com normalistas ${ }^{322}$, leva ao grupo de expertos a questionar e apontar a possibilidade de que o quinto ônibus tomado pelos estudantes tenha sido, de fato, um ônibus com droga ou dinheiro ${ }^{323}$ e que a resposta hostil, generalizada e altamente violenta das autoridades de Iguala e Cocula (e os "policiais" cujo

\footnotetext{
${ }^{317}$ Informe Ayotzinapa II, pág: 238.

318 Ídem, pág: 324.

${ }^{319}$ Informe Ayotzinapa I, pág: 324.

${ }^{320}$ Informe Ayotzinapa II, pág: 162.

321 "According to a 131-page complaint affidavit unsealed yesterday, Vega worked with various narcotic sources in Mexico to import wholesale amounts of heroin and cocaine from Mexico to Illinois, often concealing the narcotics in commercial passenger buses that traveled from Mexico to Chicago." - Department of Justice - U.S. Attorney's Office - Northern District of Illinois, publicado em 10 de dezembro de 2014, disponível em: https://www.justice.gov/usao-ndil/pr/eight-defendants-charged-distributing-heroin-chicago-area-behalf-guerrerounidos - acessado em maio de 2016.

322 Informe Ayotzinapa I, pág: 325.

${ }^{323}$ Informe Ayotzinapa I, pág: 324.
} 
equipamento era "muito moderno"), em cumplicidade com a passividade do Exército Mexicano e a informação fornecida pela Polícia Federal, se configure como uma colusão dos agentes do Estado e agentes do narcotráfico no tráfico da mercadoria e, além do mais, que a condição de "estudante normalista" e o aproveitamento dos estigmas sociais e das caraterísticas que os tornam um Outro-indesejável diante do Estado e da população, tenham servido como paliativo da violência executada.

\begin{abstract}
"Concebir la violencia de esta forma inhibe la solidaridad ciudadana de muchas maneras. Hace invisible la violencia predatoria que los grupos criminales cometen contra la población civil y la violencia ilegal que el Estado comete contra cualquiera. Además, crea una división tajante entre ciudadanos y víctimas. Como la 'guerra contra las drogas' es una guerra entre criminales, se infiere que sus perpetradores son criminales, pero sus víctimas también. Son víctimas culpables, víctimas voluntarias. El lenguaje cotidiano lo expresa de muchas formas: 'se lo buscaron', 'se metieron en malos pasos', 'anduvieron con los malandros', 'algo debían', 'algo habrán hecho...”. Andreas SchedlerA chama da indignação $o^{324}$.
\end{abstract}

A versão sustentada pelo GIEI se configuraria então como evidência da existência do NarcoEstado no México e da aliança que o governo priísta de Enrique Peña Nieto estabeleceu com os cartéis da droga. Porém, a PGR nunca considerou aprofundar na linha de investigação apresentada pelo grupo de expertos independentes e são eles mesmos os que têm feito as diligências correspondentes descobrindo, por exemplo, que a rota que o ônibus tomou após os estudantes terem descido passa perto de um aeródromo, coincidência suspeita que seria consistente com a teoria da possível presença droga no ônibus tomado pelos normalistas. $\mathrm{O}$ GIEI considera, sem afirmar, que essa coincidência deveria ser investigada ${ }^{325}$.

Em abril de 2016, após a apresentação do Informe Ayotzinapa II que evidenciava irregularidades na investigação, a presença de Tomás Zerón de Lucio de forma clandestina no rio San Juan e a reafirmava a impossibilidade da queima no lixão de Cocula ter acontecido, o Estado mexicano dá por concluída a sua relação de assistência com o GIEI e não aceita uma prorrogação para o grupo se manter presente no país. Em paralelo os expertos independentes

\footnotetext{
${ }^{324}$ La llama de la indignación - Andreas SCHEDLER, publicado em 14 de novembro de 2014 em REFORMA, disponível em: http://www.reforma.com/aplicaciones/articulo/default.aspx?id=393670\&impresion=1 - acessado em maio de 2016 - O artigo em REFORMA requer cadastro no portal, uma versão gratuita encontra-se em: https://docs.google.com/document/d/1BZbwuGyBgbYZFwVklvta2pZxKdEk8BQo50IfW0SvIhg/pub - acessado em maio de 0216.

325 "El trayecto seguido por el autobús esa noche no se ajusta a los tiempos habituales de desplazamiento por dicha zona (...) El GIEI realizó el recorrido observando que dicha ruta pasa por un lugar cercano a un aeródromo, lo cual debería investigarse." - Informe Ayotzinapa II, pág: 244.
} 
anunciam que não continuarão colaborando com o Estado mexicano "[...] ante la vulneración por parte de la PGR de acuerdos previos establecidos en Washington, y después en México, sobre el abordaje que se daría a los resultados del peritaje ${ }^{326 " . ~ O ~ a n t e r i o r ~ r e s u l t a d o ~ d o ~ a c o r d o ~}$ prévio que o GIEI e a PGR haviam feito sobre informar dos resultados da perícia no lixão de Cocula de forma conjunta respeitando a autonomia dos peritos do fogo. Mediante um comunicado de imprensa o GIEI denuncia que a PGR rompeu unilateralmente o acordo e entregou à população e opinião pública, uma hora antes da conferência de imprensa conjunta previamente estabelecida, resultados que "[...] no fueron las explicadas al GIEI durante la reunión, ni son del consenso de los expertos de fuego 327 ", para assim declarar, através da CIDH que não existem mais condições para que o grupo de expertos independentes continuasse trabalhando no México ${ }^{328}$ e assim oficializar a sua saída do país.

Os pontos expostos ao longo do presente apartado não representam uma conclusão jurídica já que a presente dissertação não é um documento de investigação oficial, porém, apresenta fatos e eventos documentados tanto na imprensa especializada de investigação jornalística como nos relatórios e informes do GIEI, da PGR e de organismos internacionais com a intenção de trazer à discussão o contraste existente entre as investigações oficiais de uma dependência oficial do Estado, involucrada nas diligências de um caso de desaparição forçada levada a cabo por agentes do próprio Estado, e as investigações de organismos independentes cuja participação no caso não representa nem implica um conflito de interesse institucional, pessoal, ideológico ou político. Ao fazer o anterior, tenta-se visualizar e posicionar ao Estado e às suas dependências como perpetradores e materializadores diretos ou indiretos de um crime de Estado, em conjunto com agentes do narcotráfico, contra uma população particular caracterizada por ser parte do Outro-indesejável por questões políticas, raciais e socioeconômicas. O anterior através da mobilização institucional do aparelho de segurança do Estado nos labores diretos e indiretos de ataque e a posterior mobilização do aparelho judiciário

\footnotetext{
${ }^{326}$ Cesa GIEI colaboración con PGR en peritaje de Cocula y la acusa de violar acuerdos - Gloria Leticia DÍAZ em PROCESO, publicado em 6 de abril de 2016, disponível em: http://www.proceso.com.mx/436086/cesa-gieicolaboracion-la-pgr-en-estudio-cocula-acusa-violacion-acuerdos - acessado em maio de 2016.

${ }^{327}$ La PGR rompió el acuerdo con el GIEI sobre el nuevo peritaje de Cocula - Comunicado de Imprensa disponivel no portal oficial do GIEI através de: http://prensagieiayotzi.wix.com/giei-ayotzinapa\#!LA-PGR-rompió-elacuerdo-con-el-GIEI-sobre-el-nuevo-peritaje-de-Cocula/cul3/56ff1e990cf2d8d402fe3acb - publicado em 1 de abril de 2016, acessado em maio de 2016.

328 "No hay condiciones" para que siga en México el GIEI, concluye la CIDH - Redacción Proceso em PROCESO, publicado em 15 de abril de 2016, disponível em: http://www.proceso.com.mx/437247/condiciones-siga-enmexico-giei-concluye-la-cidh - acessado em maio de 2016.
} 
para bloquear e dirigir as investigações o mais longe possível do governo federal e das instituições militares e policiais.

\section{A Resposta Civil}

A cidadania foi tomada por surpresa pelo começo da guerra contra os cartéis no mandato de Felipe Calderón. Embora os cartéis hajam estado presentes desde tempo atrás e possa ter existido uma convivência pacifica ou tolerada entre cidadania e narcotráfico, a entrada do exército em atitude beligerante na equação mudou o cenário. Os ataques contra a população civil anteriormente descritos, seja por parte dos cartéis, das forças estatais ou de uma mistura de ambos, provocou a resposta civil materializada maioritariamente em protestos e campanhas sociais através da mídia tradicional ou das redes sociais ${ }^{329}$ que se afastavam das campanhas oficiais do Estado, já descritas, que fracassavam monumentalmente na sua tentativa de se aproximar da população, particularmente das parcelas jovens no geral, com uma retórica conservadora e pouco atraente para uma juventude totalmente alheia a um governo conservador como o de Calderón ou de herança autoritária como o de Peña Nieto.

Tal era a ruptura e o afastamento da cidadania para com o Estado que do coração da Universidad Iberoamericana - UI, universidade particular tradicionalmente destinada às classes média-alta e com pouca a nula história de ativismo e participação estudantil na vida política do país, nasceu a mobilização estudantil mais importante dos últimos anos: o movimento \#YoSoy132 $2^{330}$,

\footnotetext{
${ }^{329}$ Caso emblemático foi a campanha No+Sangre organizada por periodistas e caricaturistas independentes em 2011 quando o país atravessava um dos momentos mais difíceis durante a guerra de Calderón. Promovida por José Hernández (@monerohernandez), Rius e Patricio Monero (@monosdepatricio) - Caricaturistas mexicanos promueven la campaña “;Basta de sangre!” - Tania L. MONTALVO em Expansión CNN, publicado em 10 de janeiro de 2011, disponível em: http://expansion.mx/nacional/2011/01/10/caricaturistas-mexicanos-promuevenla-campana-basta-de-sangre - acessado em maio de 2016.

$330 \mathrm{O}$ movimento \#YoSoy132 surgiu após a visita de Enrique Peña Nieto, ainda como candidato à presidência, à Universidad Iberoamericana - UIA; nessa visita, os estudantes mostraram o descontento com o PRI, o candidato e a influência da empresa Televisa nas eleições; diante da pressão, o futuro presidente se esconderia em um banheiro da universidade e posteriormente a equipe de campanha afirmaria que foram apenas 131 estudantes os inconformes; assim nasceria a frase Yo soy 132 (eu sou 132). O movimento se espalharia além da UIA para outras universidades, tanto públicas como privadas.
} 
comparável, com as devidas precauções, provavelmente à mobilização que levou à greve da UNAM em 1999.

As diferenças são gigantescas entre ambos os movimentos: um nasceu da universidade particular, outro da pública; um se articulou em torno da participação estudantil na vida política da nação, especialmente as eleições, enquanto o outro defendia à autonomia e à universidade pública; o primeiro tentou se articular com todas as universidades do país, porém, seguindo uma lógica de "lideranças" originadas a partir da hierarquização do movimento, o segundo conseguiu de fato a união e integração sem recorrer à ideia do "líder" ou do "homem branco salvador" vendida nas universidades da classe alta; e finalmente, \#YoSoy132 foi um movimento que, se bem conseguiu temporariamente unificar aos estudantes, nunca conseguiu definir uma posição estável e, em nome da "diversidade de opiniões e objetividade", oscilava entre a oposição absoluta a Enrique Peña Nieto e o discurso conciliador, covarde para alguns, de não tomar posição a favor ou contra algum candidato em particular. No final, enquanto o movimento da UNAM em 1999 logrou algumas conquistas importantes e foi derrotado apenas pela invasão da PFP ao campus principal, o movimento \#YoSoy132 se fragmentou, se deslindaram e se acusaram uns e outros e finalmente desapareceu vítima dos próprios erros.

O fracasso rotundo do movimento \#YoSoy132 logo no começo da administração de Peña Nieto (2012) leva a considerar o surgimento de outras mobilizações no país, principalmente no interior da república, nos lugares mais atingidos pela violência incessante da guerra contra as drogas e posteriormente do NarcoEstado. Em paralelo, se bem o movimento \#YoSoy132 tinha potencial, a própria natureza recatada e politicamente correta das lideranças da UI, incompatível com as lideranças que surgiram nas universidades públicas, fez do movimento uma ameaça de nível baixo para o Estado. É sintomático que as forças de segurança do Estado não tenham apelado à repressão violenta em momento nenhum durante os protestos nem feito a prisão dos líderes do movimento como tradicionalmente se faz. Mesmo assim, o movimento foi atacado e desarticulado pelo Estado do jeito priísta tradicional: a cooptação e integração dos líderes ${ }^{331}$ no aparelho estatal. O governo foi favorecido pelo enfraquecimento do movimento a causa dos erros internos, das ambições individuais e da falha na articulação com as universidades públicas pela arrogância dos líderes da UI.

\footnotetext{
${ }^{331}$ A empresa Televisa, um dos principais alvos das críticas do movimento, ofereceu emprego aos líderes do movimento em programas de "analise" político - Ex vocero de \#YoSoy132, ahora en Televisa, desata ira en redes - Víctor SOLÍS em El Universal, publicado em 24 de outubro de 2012, disponível em: http://archivo.eluniversal.com.mx/notas/878627.html - acessado em maio de 2016.
} 
Do anterior surge o contraste do agir do Estado diante dos movimentos sociais dependendo da magnitude da ameaça que representam, enquanto o \#YoSoy132 praticamente caiu sozinho e o Estado deu apenas o tiro de misericórdia, os dois movimentos que serão descritos a continuação receberam um trato algo diferenciado: 1) o surgimento das Autodefesas Cidadãs no estado de Michoacán para combater à presença dos cartéis da Familia Michoacana, Los Zetas e Caballeros Templarios, mobilização que levou ao conflito contra a Polícia Federal e o Exército Mexicano e cujo desenlace evidencia, novamente, a existência do NarcoEstado durante a administração de Peña Nieto; e 2) Os protestos cidadãos para exigir a apresentação com vida dos 43 estudantes desaparecidos sob o lema de \#FueElEstado (foi o Estado) e organizados em mobilizações massivas acontecidas em distintos países conhecidas como Acción Global Ayotzinapa.

\section{As autodefesas cidadãs}

O conflito no estado de Michoacán é antigo dada a localização do estado no litoral pacífico ao sul do estado de Jalisco, base de operações do antigo Cartel de Guadalajara. Michoacán tem sido desde então um ponto focal na produção de maconha e, posteriormente, de outras drogas. A situação geográfica do estado é determinante na produção e tráfico de drogas, lembrando que o estado possui o estratégico porto de Lázaro Cárdenas e a zona montanhosa da Sierra Madre del Sur, lugar de cultivo de papoula e maconha. Em paralelo, o litoral michoacano serve como ponto de entrada de cocaína proveniente da Colômbia e o porto de Lázaro Cárdenas recebe os precursores químicos para drogas sintéticas vindos da Ásia ${ }^{332}$.

A posterior fragmentação dos cartéis e o surgimento de outros fez que o estado virasse uma zona de guerra pelo controle do território de tráfico e produção de estupefacientes. O conflito pode ter se originado com a chegada dos Zetas, então braço armado do Cartel del Golfo, para combater o crescente poder de Joaquín Guzmán e o Cartel de Sinaloa no começo do século $\mathrm{XXI}^{333}$. A chegada dos Zetas e o terror que os caracteriza provocaria o surgimento da Familia

\footnotetext{
${ }^{332}$ Autodefensas, policías comunitarios, paramilitares: La confusión de Michoacán - Norberto EMMERICH, Publicado em 10 de fevereiro de 2010 no portal da Agencia Paco Urondo, disponível ORIGINALMENTE em: http://agenciapacourondo.com.ar/opinion-846232/13128-autodefensas-policias-comunitarios-paramilitares-laconfusion-de-michoacan -, porém, uma versão mais completa encontra-se disponível em: http://ojos-delmundo.blogspot.com.br/2014/01/las-autodefensas-de-michoacan-un.html - acessado em maio de 2016.

333 "2001.- Llegada de los Zetas. La disputa por el trasiego de cocaína se agudizó entre los cárteles. Los Zetas, entonces brazo armado del Cártel del Golfo, llegaron a Michoacán con la intención de apropiarse de la plaza a sangre y fuego." - \#MichoacánEnGuerra: Cronologia mínima - Jenaro VILLAMIL, publicado em Proceso - 14 de janeiro de 2014, disponível em: http://www.proceso.com.mx/362364/michoacanenguerra-cronologia-minima acessado em maio de 2016.
} 
Michocana, originalmente concebido como um grupo armado para fazer frente ao terror dos Zetas cujo pronunciamento inaugural foi jogar cabeças de sicários decapitados em uma boate de Uruapan, interior do estado, em 2006, no começo da guerra contra o narcotráfico.

O momento em que a Familia Michoacana virou cartel é desconhecido, mas sabendo que o mercado de tráfico de drogas é altamente lucrativo e o estado já era um caldeirão de produção de maconha e drogas sintéticas, a tentação pode ser insuportável e, em um mundo de alianças e traições como é o mundo do narcotráfico, a possibilidade do Cartel de Sinaloa ter cooptado à Familia Michoacana, rival natural dos Zetas, não é uma ideia impossível ${ }^{334}$. A expansão violenta do novo cartel e eventos como o ataque com granadas no centro de Morelia foram o estandarte e justificativa do começo da Operação Michoacán, a primeira ofensiva militar da guerra contra os cartéis durante o governo Felipe Calderón. Como já foi mencionado a péssima estratégia, ou falta de, da guerra calderonista foi determinante para fracassar no combate dos cartéis já preparados para a guerra. A estratégia simples e pueril de buscar eliminar às cabeças dos cartéis para dar um golpe mediático provoca a disputa interna nos cartéis pela liderança. No caso da Familia Michoacana, provocou uma cisma interna que deu origem aos Caballeros Templarios e o começo da guerra interna no estado de Michoacán, situação que se complicaria com o surgimento do cartel Jalisco Nueva Generación ${ }^{335}$.

No dia 24 de janeiro de 2013 aparecem em La Ruana, povoado do município de Buenavista e Tepalcatepec, grupos de homens armados com a intenção de resistir e confrontar aos Caballeros Templarios, os quais tinham estabelecido em regime de extorsão e sequestros na região. Sob o comando de José Manuel Mireles Valverde, médico cirurgião da Universidad Michoacana e Estanislao Beltrán, conhecido como "Papá Pitufo" (equivalente a Papai Smurf), as autodefesas tomam o controle dos povoados próximos desarmando às forças de segurança locais por estarem supostamente cooptadas pelos Templarios $^{336}$. As autodefesas se espalharam a 33 municípios do estado de Michoacán, equivalentes a $32.897 \mathrm{~km} 2$, isto é, o $56.10 \%$ da totalidade

\footnotetext{
334 "Todo hace suponer que La Familia hizo un pacto con el Cártel de Sinaloa, encabezado por "El Chapo" Guzmán, para compartir el territorio y el puerto estratégico de Lázaro Cárdenas, Michoacán." Ídem.

335 "2010-2012.- Irrumpen Los Templarios. Como sucedió con El Golfo y Los Zetas, con el cártel de Sinaloa y los Beltrán Leyva, el cártel de La Familia se fragmentó y comenzó una disputa por el liderazgo y control del negocio tras el descabezamiento de sus líderes. Surgió un nuevo grupo, copia de las tácticas y estrategias de penetración política y social de La Familia: Los Caballeros Templarios." Ídem.

336 “(...) se levantan los primeros grupos armados para hacer frente a la organización criminal Los Caballeros Templarios, quienes extorsionaban y secuestraban (...) las autodefensas se expandieron a 27 municipios (..) Al menos 25 elementos de la Policía Municipal de Vista Hermosa fueron detenidos por personal militar, por presuntos nexos con la delincuencia organizada (...). ”- Se levantaron em armas; ahora se desarman. Cronología - Redacción Milenio, publicado em 28 de abril de 2014; disponível em: http://www.milenio.com/policia/autodefensas-templarios-armas-desarman-Cronologia-guardiascomunitarios_0_289171580.html -acessado em maio de 2016.
} 
do território michoacano segundo dados da CNDH através do Informe Especial Sobre os Grupos de Autodefesa ${ }^{337}$.

Norberto Emmerich ${ }^{338}$ faz uma análise do surgimento das autodefesas no marco do combate armado contra o narcotráfico levantando a questão da modificação da lógica da violência produzida a partir do conflito entre forças do Estado, traficantes e entre os próprios cartéis. Porém, afirma Emmerich, o surgimento de uma terceira força encarnada nas autodefesas provocou o deslocamento não apenas dos traficantes, senão das forças estatais em um estado economicamente estratégico pela presença do porto de Lázaro Cárdenas, situação que de raiz coloca às autodefesas como alvo do Estado e dos cartéis. No entanto, os grupos de autodefesa continuaram se expandindo, desarmando aos policiais locais e expulsando aos prefeitos municipais por terem nexos com os cartéis. Isto é, para Emmerich, uma afronta ao Estado priísta ao atacar aspectos fundamentais do domínio do partido como são: 1) o monopólio dos médios de violência; 2) a legitimidade e intangibilidade dos cargos públicos eleitos; 3) a capacidade das autoridades de adotar decisões autoritativas obrigatórias para todos; e 4) a reapropriação do conceito de "guerra justa",339. O anterior com o apoio inicial da população das cidades tomadas pelas autodefesas, evidenciado no confronto que as autodefesas tiveram com o Exército Mexicano no povoado de Apo quando militares tentaram desarmar aos membros da autodefesa do Dr. Mireles, situação que foi resolvida com a intervenção da população civil contra os soldados, cena magistralmente registrada no documentário Cartel Land (2015) de Matthew Heineman $^{340}$.

As circunstâncias que favoreceram o surgimento das autodefesas em Michoacán são as de um verdadeiro estado de terror e de sitio por parte dos grupos de crime organizado contra a população civil e o governo estatal no meio da equação. Os dados apresentados pela CNDH no informe sobre as autodefesas demonstram esse contexto de terror no ano de 2013. Apontam que a partir de 2.858 testemunhas recavadas, se observou que que todos foram vítimas diretas ou indiretas de diversos delitos contra a sua vida, integridade e patrimônio; delitos como: a) lesões;

\footnotetext{
${ }^{337}$ Informe Especial sobre los Grupos de Autodefensa en el Estado de Michoacán y las Violaciones a los Derechos Humanos relacionados con el Conflicto - CNDH, públicado em 2016; disponível em: http://www.cndh.org.mx/sites/all/doc/Informes/Especiales/2016_IE_gruposautodefensa.pdf - acessado em maio de 2016. Pág: 25.

${ }^{338}$ Autodefensas, policías comunitarios, paramilitares: La confusión de Michoacán - Norberto EMMERICH. Op.Cit.

${ }_{339}^{3}$ Ídem - Apartado 3.

${ }^{340}$ CARTEL LAND. Direção: Matthew Heineman, Produção: Matthew Heineman, Tom Yellin, Kathryn Bigelow, Molly Thompson. EUA: The Documentary Group, Our Time Projects, 2015. Cena selecionada a partir do minuto 19. - Disponível em Netflix.
} 
b) extorsão; c) sequestro; d) homicídio; e) estupro; f) afetações ao patrimônio; g) deslocamento forçado; e h) privação ilegal da liberdade, entre outros. As 2.858 testemunhas se declararam vítimas diretas ou indiretas de um ou mais dos delitos mencionados entregando a quantidade de 3.027 denúncias e se acrescentam outras 2.111 vítimas referidas pelos entrevistados como conhecidos ou vizinhos ${ }^{341}$.

O surgimento das autodefesas coincide com a volta do PRI ao poder no estado de Michoacán. O estado é o lugar natal do ex-presidente Felipe Calderón e foi o primeiro estado alvo do Exército Mexicano no começo da guerra contra os cartéis; foi também historicamente governado pelo PNR/PRI (1928-2002) até a chegada ao poder do PRD que governaria até 2012. Previamente, o governo estatal do PRD seria diretamente atacado através do evento conhecido como o "Michoacanazo" 342 de 2009, operação dirigida para prender figuras políticas ligadas ao narcotráfico durante a guerra calderonista. Resulta curiosa a veemência com a que dita operação se dirigiu contra o partido opositor a Calderón no estado natal de este último. Este golpe provocaria saída do PRD em 2012, ano que Enrique Peña Nieto ganharia as eleições gerais e Fausto Vallejo, também do PRI, ganharia a eleição em Michoacán.

Todo o anterior coincide com a aparição dos Caballeros Templarios e o aumento da violência em um estado que já era considerado violento. As suspeitas de colusão entre o governo estatal e o narcotráfico, em particular os Caballeros Templarios, não demoraram em aparecer assim como as primeiras insurreições dos grupos de autodefesa. Os vínculos de Fausto Vallejo com os Templarios foram finalmente evidenciados ao flagrar ao filho, Rodrigo Vallejo, em reuniões com Servando Gómez "La Tuta”, capo do cartel dos Caballeros Templários. O filho do governador foi preso e descobriu-se que funcionava como articulador entre a Familia Michoacana, em um primeiro momento, e dos Templarios posteriormente, com a classe política e a polícia municipal, situação que em parte favoreceu a campanha eleitoral do seu pai. Com o filho preso, Fausto Vallejo apresentaria a sua renúncia em $2014^{343}$.

\footnotetext{
${ }^{341}$ Informe Especial sobre los Grupos de Autodefensa en el Estado de Michoacán y las Violaciones a los Derechos Humanos relacionados con el Conflicto - CNDH, pág: 28. Op.Cit.

${ }^{342}$ Foram presos um total de 38 funcionários públicos, maioritariamente do PRD mais com presença do PRI e pouca do PAN; todos os detidos durante a operação encontram-se em liberdade dada a fragilidade das provas apresentadas pela PGR. Embora a inocência dos presos ainda seja questionada, a operação parece mais uma manobra política do governo de Calderón contra o PRD - De 38 detenidos por Michoacanazo, 37 libres Redacción El Universal, publicado em 20 de setembro de 2010, disponível em: http://archivo.eluniversal.com.mx/notas/712154.html - acessado em maio de 2016.

${ }^{343}$ Vallejo: Un gobernador por el narco y para el narco - José GIL OLMOS em PROCESO, públicado em 21 de junho de 2014, disponível em: http://www.proceso.com.mx/375389/vallejo-un-gobernador-por-el-narco-y-parael-narco - acessado em maio de 2016.
} 
Com o anterior, devemos voltar e considerar a insurreição dos grupos de autodefesa no contexto michoacano de 2013 - 2014 a partir da existência de um Estado de exceção de fato no território, e da questão da legalidade/legitimidade e o direito à resistência do povo. A situação no estado com a deflagração da Operação Michoacán acrescentou ao exército em um contexto no qual já combatiam a Familia Michoacana e os Zetas pelo controle do território com o apoio do Cartel de Sinaloa aos primeiros. A guerra gerou as obviedades: clima bélico e a fraqueza ou ausência do Estado tanto nos territórios como no aparelho de governo e, portanto, não podia oferecer mais condições básicas de vida aos cidadãos, se aproximando ao Estado falido. Os buracos feitos na estrutura de administração política e a penetração do narcotráfico na sociedade produto do "vazio de Estado" criado pelo clima bélico favoreceram o surgimento de figuras como Rodrigo Vallejo, personagens ligadas à classe política e cooptadas pelo narcotráfico para serem os seus representantes dentro do aparelho estatal. Porém, nesse momento seria possível apenas falar de um NarcoEstado local que ainda não se articulava ao grande Estado no nível federal. A intervenção posterior do governo federal através do seu braço armado, o Exército Mexicano, evidenciará esta afirmação.

Por enquanto, a situação deteriorada de Michoacán, vítima do combate entre os Zetas e o governo estatal em função dos Templarios, criou um Estado de exceção de fato emanado da falência do Estado federal e local na sua tarefa de administração do território michoacano. As instituições de acesso à justiça e, principalmente, de segurança, abandonam as suas tarefas institucionais e se dirigem ao combate contra os Zetas e ao funcionamento de máfia ao cobrar proteção aos cidadãos e outras atividades caraterísticas, como o sequestro e a execução. Diante de este cenário de abandono das funções institucionais e, por consequência, o cancelamento de facto das garantias individuais, a falência do Estado gera um clima de exceção que, em conjunto com a presença bélica do governo federal através do Exército e Polícia Federal, cancela a legalidade e deixa tudo no campo aberto da legitimidade já que: a) as autoridades locais não mantêm mais a ordem social, não têm interesse e, além do mais, a combatem; b) os cartéis são o governo e o governo são os cartéis, manter a ordem social constitucional não faz parte das funções primordiais, e c) os militares e os policiais federais não tem a capacidade de manter a ordem social $^{344}$.

\footnotetext{
${ }^{344}$ Michoacán: de la autodefensa al conflicto armado - Iliana RODRÍGUEZ SANTIBÁÑEZ em Forbes México, publicado em 15 de janeiro de 2014, disponível em: http://www.forbes.com.mx/michoacan-de-la-autodefensa-alconflicto-armado/ - acessado em maio de 2016.
} 
Diante de esta bolha de exceção dentro da legalidade (i.e., Estado de exceção de facto), apenas resta a legitimidade auto afirmada para agir, uma legitimidade que se fundamenta nas necessidades primordiais do indivíduo: a preservação da vida e da moradia. Portanto, eis a questão: embora as autodefesas estejam legitimadas pela defesa da vida e da propriedade em um contexto bélico diante do abandono (e ataque) institucional do Estado local cooptado pelos cartéis, seria possível reconhecer o direito à rebelião dos cidadãos contra instituições estatais corrompidas pelo narcotráfico a partir do marco da legalidade que, embora esteja cancelado no território em questão, continua funcionando desde a perspectiva do governo federal? A resposta é não. O Estado federal jamais reconhecerá o direito à rebelião dos cidadãos diante dele mesmo nem das suas subdivisões territoriais sob circunstância nenhuma por mais extrema que a situação seja, isto é, reconhecer o direito à rebelião sentaria uma espécie de jurisprudência a futuro que legitimaria a rebelião e possibilitaria a sua materialização através da legislação, isto para um Estado com as características do priísmo resulta simplesmente impensável. Norberto EMMERICH afirma que as autodefesas, além de confrontar aos narcotraficantes e ao governo local corrompido, representam também uma alternativa de auto-organização fora da lógica priísta e ameaçava a deflagração de um conflito de maiores proporções ${ }^{345}$. Portanto, o agir do Estado teria que ser contundente através do Exército: "protestar sim, organizar-se não" "346.

É em este ponto quando se retoma a questão levantada da intervenção do governo federal em Michoacán para articular ao narcoestado local no NarcoEstado nacional. Após o avanço das autodefesas pelo estado, em especial o grupo liderado pelo Dr. Mireles e Estanislao Beltrán "Papai Smurf", e em vista da possível queda do narcogovernador Fausto Vallejo, os mecanismos de cooptação priísta entram em ação desde o governo federal com a consigna oficial de restabelecer a ordem e governabilidade de Michoacán e a consigna extraoficial de acabar com possíveis formas de organização extra-priístas.

Forças militares e batalhões da Polícia Federal entram no estado de Michoacán nos primeiros dias de 2014 retomando o controle de diversos povoados, assumindo as tarefas de segurança da

\footnotetext{
${ }^{345}$ Considero rebatível a ideia de gerar um conflito de maiores proporções ou, nas palavras de EMMERICH, uma "guerra". O uso da semântica para abafar cenários é corriqueiro e tem função política e social, o qual faz da posição de EMMERICH uma contradição ou, quando menos, um posicionamento confortável para o Estado mexicano e, portanto, suspeito. O autor considera o conflito no México e no Michoacán como uma disputa territorial entre grupos armados, civis e forças estatais, o qual configura um eufemismo simples do conceito de GUERRA, de intensidade variável, mas guerra finalmente. Provavelmente a intenção de EMMERICH era diferenciar entre a sua ideia de conflito interno e GUERRA CIVIL, o qual de novo cai no campo do eufemismo e do uso cobarde, moralista e político da semântica, caraterística da academia cientificista e medrosa.

${ }^{346}$ Autodefensas, policías comunitarios, paramilitares: La confusión de Michoacán - Norberto EMMERICH, Op. Cit.
} 
desaparecida polícia municipal e desarmando aos grupos de autodefesas ${ }^{347}$. Isto foi um evento sumamente criticado pela ostensiva demonstração de força bélica do Estado contra os cidadãos organizados e não contra os narcotraficantes e, além do mais, pelos confrontos que aconteceram entre autodefesas e militares durante a "invasão" do estado como é relatado durante a retomada de Parácuaro e Nueva Italia. No combate entre as autodefesas e militares se reportaram quatro mortos por tiros dos militares, dentre eles uma criança de 11 anos de idade ${ }^{348}$.

Após a entrada violenta e ostensiva do Estado, começaria o processo de cooptação burocrática com a criação da Comisión para la Seguridad y el Desarrollo Integral de Michoacán ${ }^{349}$. Em esta comissão, Enrique Peña Nieto indicaria a um amigo próximo, negociador excelso e fabricador de confiança que foi mencionado anteriormente no caso da menina Paulette, trata-se de Alfredo Castillo, quem funcionaria como Comissionado de Segurança e efetivamente assumiria os labores de Fausto Vallejo como governador em linha direta com o governo federal sustentado pelos artigos $1^{\circ}, 2^{\circ}, 3^{\circ}, 4^{\circ}, 5^{\circ} /$ I-II-III-V-VI-VII-VIII-XI, $7^{\circ}, 8^{\circ}$ e $9^{\circ}$ (isto é, 8 de 10 artigos) do decreto que criou a Comissão ${ }^{350}$, situação que representa um ataque e uma violação direta ao Pacto Federal e à soberania de cada estado da União Mexicana. O fato de isso ter acontecido é, novamente, explicado somente através da perspectiva do Estado de exceção.

A proposta insígnia do agora conhecido como "Vice-rei" Alfredo Castillo seria a institucionalização e legalização dos grupos de autodefesa, isto é, a integração na estrutura de administração priísta. O Dr. Mireles seria o principal opositor da institucionalização das autodefesas e a sua transformação em Polícia Comunitária, posição que resultaria na sua destituição como cabeça do grupo e a entrada de Estanislao Beltrán, agora aliado de Alfredo

\footnotetext{
347 "12 de enero. Por la noche, elementos del Ejército y de la Secretaría de Marina se movilizaron a la zona de Tierra Caliente y entraron a los municipios de Múgica y Parácuro para tomar por completo el control de la seguridad, además del desarme de los grupos de autodefensa." - Se levantaron en armas; ahora se desarmanRedacción Milenio, Op.Cit.

${ }^{348}$ Autodefensas chocan con el Ejército en Michoacán; se resisten al desarme - Redacción AN, publicado em 14 de janeiro de 2014, disponível em: http://aristeguinoticias.com/1401/mexico/autodefensas-chocan-con-el-ejercitoen-michoacan-se-resisten-al-desarme/ - acessado em maio de 2016.

${ }^{349}$ DECRETO por el que se crea la Comisión para la Seguridad y el Desarrollo Integral en el Estado de Michoacán - Diario Oficial de la Unión - 15 de janeiro de 2014 - Disponível em: http://www.dof.gob.mx/nota detalle.php?codigo=5329743\&fecha=15/01/2014 - acessado em maio de 2016.

$3501^{\circ}$ : Estabelece a ligação direta com o governo federal; $2^{\circ}$ Formulação e execução de políticas públicas; $3^{\circ}$ Nomeação direta do Comissionado pelo Ministro do Interior; $4^{\circ}$ : Faculta ao comissionado para coordenar às autoridades federais para restabelecer a ordem; $5^{\circ}$ : O comissionado está facultado para I) Ser o conduto direto do Ministro do Interior, II) Formular e executar políticas públicas, III) Articular às autoridades federais com as locais, V) Dar ordens às autoridades federais e locais, VI) Coordenar e comandar às forças federais e locais, VII) Solicitar o apoio do Exército Mexicano, VIII) Solicitar, via Ministro do Interior, a destituição de autoridades locais, XI) Fazer qualquer outra coisa que o Ministro do Interior demande; $7^{\circ}$ : Faculta ao comissionado a celebrar convênios com autoridades locais; $8^{\circ}$ : Os funcionários federais devem seguir as ordens do Comissionado; e $9^{\circ}$ : O Ministro do Interior pode destituir ou nomear autoridades federais vinculados ao Comissionado.
} 
Castillo. No dia 10 de maio de 2014 se formaliza a desaparição dos grupos de autodefesa e a criação da Força Rural e da Polícia Comunitária sob administração direta do governo estatal e federal $^{351}$. Poucos dias depois, o Dr. Manuel Mireles, ainda em franca oposição à institucionalização das autodefesas, é detido por forças federais enquanto planejava a toma do município de La Mira para desarticular, segundo afirma, ao grupo criminal de Los Viagras ${ }^{352}$, ex-autodefesas organizados agora como cartel, que operam em um lugar estratégico de trânsito de precursores químicos pela proximidade com o terceiro porto mais importante do país, o porto de Lázaro Cárdenas. Mireles permanece preso até o dia de hoje, momento em que se escreve a presente dissertação ${ }^{353}$.

As denúncias de Mireles e do jornalismo de investigação contra Alfredo Castillo não demoraram em aparecer. Castillo foi acusado de negociar e de ter linha direta com os Caballeros Templarios por Mireles ${ }^{354}$ e pelo sacerdote de La Ruana, José Luis Segura quem o acusa de ter autorizado a infiltração de ex-Templarios nas policias comunitárias que foram criadas e a perseguição dos líderes que recusaram a institucionalização, como Mireles e Hipólito Mora ${ }^{355}$. Em paralelo, o jornalismo de investigação o acusa de pactuar com o grupo de Los Viagras, o próximo alvo do Dr. Mireles antes de ser preso, para integrá-los à Polícia Comunitária sob o nome de G-250 para combater aos Templários. Este pacto teria derivado diretamente na prisão de Mireles ${ }^{356}$ e no confronto em Apatzingán entre a Polícia Federal, militares e policiais

35115 momentos de las autodefensas en Michoacán, a tres años del levantamiento (gráfico) - Laura CASTELLANOS, publicado em 24 de fevereiro de 2016 em Aristegui Noticias, disponível em: http://aristeguinoticias.com/2402/mexico/15-momentos-de-las-autodefensas-en-michoacan-a-tres-anos-dellevantamiento-grafico/ - acessado em maio de 2016.

${ }^{352}$ Los Viagras: originalmente um braço armado do cartel de La Familia, posteriormente integrados às autodefesas e à Força Rural inaugurada por Alfredo Castillo e finalmente reorganizados como cartel; vinculados com o grupo dos Guerreros Unidos, os principais suspeitos do sumiço dos 43 estudantes de Ayotzinapa - Los Viagras expanden domínio em Michoacán - Miguel GARCÍA TINOCO em Excelsior, publicado em 28 de fevereiro de 2015, disponível em: http://www.excelsior.com.mx/nacional/2015/02/28/1010818 - acessado em julho de 2016.

${ }^{353}$ Escrito em uma sexta-feira, 20 de maio de 2016, Brasília, DF.

354 José Manuel Mireles acusou ao comissionado Alfredo Castillo de outorgar fardas aos traficantes como parte de uma associação entre o Estado e ex traficantes - Mireles acusa a Castillo de asociarse con los criminales Verónica MACÍAS em El Economista, publicado em 29 de maio de 2014, disponível em: http://eleconomista.com.mx/sociedad/2014/05/29/mireles-acusa-castillo-asociarse-criminales - acessado em julho de 2016.

355 "Desde ese momento tuve que enfrentar al Americano y a sus secuaces aquí en la Ruana, el tal Monín, el 8 Valencia, la Mami y demás delincuentes, quienes fueron autorizados por (Alfredo) Castillo como los legítimos representantes de la ley en la Ruana (...) No me gustó la regularización de las autodefensas como fuerzas policiacas rurales y ciudadanas. Me pareció una traición al movimiento insurgente y una aceptación de que se hiciera una revoltura entre autodefensas legítimos y los infiltrados por los criminales, como el H3, los Viagras, los Álvarez y demás grupos delincuenciales hijitos de los Caballeros Templarios."- Legitimó Alfredo Castillo a grupos vinculados a los Templarios: Sacerdote - Redacción AN, publicado em 30 de abril de 2016, disponível em: http://aristeguinoticias.com/3004/mexico/legitimo-alfredo-castillo-a-grupos-vinculados-a-los-templariossacerdote/ - acessado em maio de 2016.

${ }^{356}$ La traición de Castillo - José GIL OLMOS, publicado em 18 de novembro de 2015 em PROCESO, disponível em: http://www.proceso.com.mx/421039/la-traicion-de-castillo - acessado em maio de 2016. 
comunitários membros do G-250, estes últimos teriam tomado o Palácio Municipal para exigir não serem desarmados e os pagamentos prometidos. O resultado foi de 16 pessoas mortas que, se afirma, estavam desarmadas e foram provavelmente executadas ${ }^{357}$. Dias depois, Alfredo Castillo anunciaria a sua renúncia e saída de Michoacán dizendo que "a história nos julgará no devido momento". As cifras 358 reportadas antes e depois do reinado do "Vice-rei" o julgam: a) assassinatos: 663 casos registrados antes x 732 casos registrados depois; b) roubos: $12.674 \mathrm{x}$ 13.288; c) extorsões: 191 x 209; e d) sequestros: 134 x 82 .

O acontecido com o Dr. Mireles como consequência da chegada de Alfredo Castillo e a criação da Polícia Comunitária e Força Rural e a desarticulação (oficial) dos Caballeros Templarios com a prisão de Servando Goméz "La Tuta" é uma ode à eficiência da capacidade de negociação priísta e da pacificação forçada e a qualquer preço do território e da população. Com um súbito movimento do braço armado do Estado, o exército, se deu um golpe de ostensividade bélica para criar um campo de legitimidade para o governo federal pela via das armas e assim criar as condições de ação para o Comissionado Alfredo Castillo, o qual, eficiente e efetivamente negociou com os líderes das autodefesas, premiou aqueles que aceitaram a institucionalização (Estanislao Beltrán) e castigou com toda a força do aparelho judiciário do Estado aqueles que se negaram (Mireles). Com a outra mão orquestrou a queda de Servando Gómez "La Tuta” e de Fausto Vallejo dando um golpe mediático legitimador. Porém, o que foi dos Templarios agora órfãos? Como foi mencionado anteriormente, a intervenção em Michoacán foi a entrada do NarcoEstado federal para articular a um narcoestado pequeno. Os Templarios restantes foram integrados nas recém-criadas Polícias Comunitárias e articulados diretamente ao funcionamento estatal no que poderia ser chamado, a maneira de tragicomédia, o Ministério do Narcotráfico, cujo funcionamento é apresentado na cena inicial e final do documentário Cartel Land $^{359}$ na qual homens fardados com insígnias da Polícia Comunitária criada pelo Vice-rei Castillo, "cozinham" metanfetamina na escuridão no meio do mato.

\footnotetext{
${ }^{357}$ Apatzingán: También los militares atacaron - Laura CASTELLANOS em PROCESO. Op. Cit.

${ }^{358}$ Alfredo Castillo se va de Michoacán; "la historia nos juzgará", dice. -Redacción AN, publicado em 22 de janeiro de 2015, disponível em: http://aristeguinoticias.com/2201/mexico/alfredo-castillo-se-va-de-michoacanosorio-chong/ - acessado em maio de 2016.

${ }^{359}$ Em ditas cenas, aparecem inicialmente um grupo de homens mascarados "cozinhando" metanfetamina na escuridão da noite no meio do mato - Na cena final, é revelado que esses homens estão utilizando fardas e insígnias da Polícia-CARTEL LAND. Op. Cit; Cenas selecionadas a partir dos minutos 00:1:00 e 1:35:00.
} 


\section{\#FueElEstado}

Se bem por um lado uma forma de resposta cidadã diante da insuportável presença dos cartéis na vida cotidiana e da paralisia do Estado, quando menos, e a sua simbiose com o narcotráfico, quando mais, foi a organização de grupos de autodefesa no interior do país, temos de considerar também as mobilizações das parcelas urbanas da população que aconteceram principalmente em torno do sumiço dos 43 estudantes de Ayotzinapa. $\mathrm{O}$ foco das mobilizações foi à Cidade do México, porém espalharam-se pelo país inteiro e pelas principais cidades do mundo exigindo a apresentação com vida dos estudantes e a investigação de funcionários públicos do nível federal chegando a, inclusive, pedir a renúncia de Enrique Peña Nieto como Presidente da República.

Os grupos envolvidos nas mobilizações foram variados, desde a classe média, baixa, setores independentes da classe operaria, contingentes inteiros de estudantes universitários tanto da pública como da particular, estudantes do sistema de ensino médio público, normalistas, camponeses e sindicatos independentes não alinhados ao PRI. Enfim, as mobilizações foram plurais e se organizaram em dias de protesto denominados como Acción Global Ayotzinapa, das quais ressalta e será analisada na presente dissertação a chamada de \#20NovMx. Por outro lado, a resposta do governo federal como a do governo do Distrito Federal foi, por dizer pouco, desproporcionada em matéria de violência e perseguição durante os dias posteriores contra manifestantes, principalmente estudantes. $\mathrm{O}$ aparelho repressivo do Estado priísta se ativou como o fazia na época dura do regime mediante a utilização de halcones, demonstração de violência ostensiva do batalhão de choque, detenções arbitrárias e extrajudiciárias e ataques diretos contra organizações e patrimônio universitário.

\section{a) Os Novos Movimentos Sociais.}

A mobilização em torno aos eventos de Iguala e Ayotzinapa se caracterizaram, no ápice da sua intensidade, por serem altamente heterogêneos, isto é, não era o movimento de alguns quantos sob uma bandeira vermelha reivindicando posicionamentos político-históricos específicos como seria esperado de um protesto de normalistas e sindicatos de camponeses. A mobilização se insere mais no que María da Glória Gohn (2000) chamaria de "novos movimentos sociais" - NMS. Em parte, o movimento por Ayotzinapa carecia de uma clara identificação tradicional no espectro político básico de esquerda e direita, embora a grande mídia e a partidocrácia hajam tentado politizar e ideologizar o movimento para lucro próprio, para fazê-lo crescer ou diminuir. Como afirma Gohn (2000, p. 122 - 123), embora seja um pouco específica, os NMS abandonam a visão marxista estruturalista de classes ancorada na perspectiva economicista e de produção 
para tomar uma perspectiva mais abrangente desde o campo político e cultural. Em paralelo, se afasta da visão reducionista do pensamento capitalista do sujeito e assume à coletividade como ator social. Uma outra caraterística é a reivindicação da participação na vida política e o confronto direto à hierarquização da esfera pública, em particular, à estabelecida pela classe política e, finalmente, este tipo de movimento tem a capacidade de articular atores sociais divergentes sob uma causa particular e ao mesmo tempo criar uma identidade em torno dessa causa. Isto significaria a reivindicação da ideia de alteridade indesejável a partir da sua desfragmentação (não importa se sou do campo, da cidade, branco, mestiço ou índio. $\mathrm{O}$ NarcoEstado nos exterminaria por igual) e a redefinição do "indesejável” para outorga-lhe um senso de orgulho ou estoicismo diante da tragédia através da criação de símbolos, no caso: $+43^{360}$.

A caraterística mais marcante e a mais definidora que Gohn estabelece para os NMS é a sua negativa absoluta de "cooperação entre as agências estatais e os sindicatos e estão mais preocupados para assegurar direitos sociais - existentes ou a ser adquiridos" (GOHN: 2000, p. 125) e se valem da mobilização social e da mídia para confrontar e pressionar às estruturas e instituições estatais, que no caso seria pertinente atualizar o escrito pela autora e acrescentar o uso das redes sociais. No entanto, afirma Gohn, esta negativa à cooperação com o Estado e organizações sindicais não implica uma ruptura quase anárquica, senão uma oposição dentro ao Estado dentro das mesmas regras do jogo sem pretender quebra-las (2000, p. 130). Pretendem trazer aquele conceito de alteridade indesejável a uma posição não apenas de vítima, senão a uma posição combativa de certa maneira. Uma vítima combativa que se redefine e outorga valor à "emergência de novas dimensões de identidade” (GOHN: 2000, p. 127) que são legitimas pela própria existência e têm como sustento aos aspectos íntimos da vida humana, aspectos trazidos para a esfera pública e política agora como elementos válidos para estruturar a contraposição ao Estado hegemônico definidor de alteridades desejáveis e indesejáveis.

No entanto, alerta Gohn (2000), o Estado ou a hegemonia em questão mobilizará os seus recursos para atrair aos NMS, cooptá-los e integrá-los ao aparelho de dominação hegemônico, ou seja, basicamente o que o PRI tem feito desde as suas origens com as distintas correntes ideológicas e sociais que coexistiam para criar ao Partido Único e que foi observado recentemente com o movimento \#YoSoy132, reduzido apenas a uma lembrança, confrontado

\footnotetext{
${ }^{360}$ Uma escultura de cor vermelha do número +43 foi levantada na Avenida da Reforma na sua interseção com Bucareli na Cidade do México, é chamada de anti-monumento - Colocan "antimonumento" 43 em Reforma por normalistas de Ayotzinapa - David VICENTEÑO em EXCELSIOR, publicado em 27 de abril de 2015, disponível em: http://www.excelsior.com.mx/comunidad/2015/04/27/1020877 - acessado em maio de 2016.
} 
entre os próprios ex-membros, agora diluído e morto, enquanto alguns líderes aceitaram posições dentro do aparelho estatal. A mensagem é clara: "Um movimento não se esgota numa secretaria governamental. Se o movimento se reduzir a isto, ele morre" (GOHN: 2000, p. 136).

As mobilizações em torno ao sumiço dos 43 estudantes, materializadas no marco dos distintos dias da Acción Global Ayotzinapa conseguiram manter a essência que Gohn (2000) descreve, situação que foi mais evidente no mês de novembro de 2014. Nos dias posteriores à desaparição e difusão do caso dos 43 estudantes, o país vivia um crescente clima de tensão pois a população não se encontrava apenas chocada pelos acontecimentos, senão que a sensação de raiva parecia cada vez mais presente. Algumas semanas depois da divulgação da "verdade histórica" na conferência de prensa de Murillo Karam, uma mobilização massiva foi marcada para o dia 20 de novembro de 2014 que coincidia com o 104 aniversário da Revolução Mexicana. Em paralelo com as principais cidades do interior da república e em conjunto com mobilizações em outras cidades do mundo ${ }^{361}$, a mobilização principal aconteceria na Cidade do México a partir de três pontos principais da capital: Monumento à Revolução, a Praça das Três Culturas de Tlatelolco e a Coluna da Independência. As mobilizações convergiriam no centro da cidade frente ao Palácio Nacional ${ }^{362}$, o qual tinha sido atacado e sofrido uma tentativa de invasão alguns dias durante um protesto como resposta à "verdade histórica": os manifestantes atearam fogo na porta principal ${ }^{363}$.

Em paralelo, a Asamblea Interuniversitaria - $\mathrm{AIU}^{364}$, que reunia representantes de distintas universidades públicas em torno do caso Ayotzinapa, informa que como parte das mobilizações

\footnotetext{
${ }^{361}$ Foram programados protestos nos Estados Unidos, Canadá, Argentina, Uruguai, Peru, Chile, Colômbia, Bolívia, Brasil, Equador, Costa Rica e Guatemala; na Europa se reportaram protestos em diversas cidades de: Espanha, França, Suécia, Alemanha, Áustria, Holanda, Inglaterra, Itália, Suíça e Noruega; outros países que reportaram mobilizações foram: Índia, Nova Zelândia e Austrália - \#20N: Programan 200 acciones de protesta por Ayotzinapa alrededor del mundo - Redacción Proceso, publicado em 19 de novembro de 2014, disponível em: http://www.proceso.com.mx/388254/20n-programan-200-acciones-de-protesta-por-ayotzinapa-alrededor-del$\underline{\text { mundo }}$ - acessado em maio de 2016.

362 Ídem.

363 Arde la puerta principal de Palacio Nacional tras marcha al Zócalo - Fernando CAMACHO SERVÍN, publicado em 9 de novembro de 2014 em La Jornada, disponível em: http://www.jornada.unam.mx/2014/11/09/politica/006n1pol - acessado em maio de 2016.

36423 universidades e faculdades se uniram à mobilização: A Faculdade de Filosofia e Letras da Benemerita Universidad Autónoma de Puebla, os Colegios de Ciencias y Humanidades Oriente e Sur, o Centro de Enseñanza de Lenguas Extranjeras, Universidad Chapingo, Escuela Nacional de Antropologia e Historia, Escuela Nacional de Entrenadores Deportivos, Escuela Nacional de Trabajo Social, as faculdades da UNAM de: Ciências Exatas, Economia, Medicina, Psicologia, Química, Artes y Diseño, Ciências Políticas e Sociais, a Facultad de Estudios Superiores Acatlán, Filosofia e Letras, Medicina Veterinária e Zootecnia; a Universidad Autonoma de la Ciudad de Mexico campi: del Valle e San Lorenzo Texcoco, a Universidad Autónoma Metropolitana unidad Xochimilco, a Unidad de Posgrado da UNAM e a Universidad Pedagógica Nacional - Desiste Asamblea Interuniversitaria de Cerco al AICM, Redacción El Universal, publicado em 19 de novembro de 2014, disponível em: http://archivo.eluniversal.com.mx/ciudad-metropoli/2014/marchas-ayotzinapa-20-noviembre-1055601.html _ acessado em maio de 2016.
} 
do \#20NovMX realizariam um bloqueio ao Aeropuerto Inernacional de la Ciudad de México AICM, ponto estratégico para a o Estado e cujo ataque, de acordo ao Código Penal Federal, pode configurar delito de ataque às vias de comunicação ${ }^{365} \mathrm{e}$, portanto, seria um dos pontos mais vigiados durante o protesto. Porém, um dia antes da mobilização, a AIU decide cancelar o bloqueio ao $\mathrm{AICM}^{366}$, isto por dois motivos: 1) os discursos prévios de Peña Nieto e do general Cienfuegos, os quais vislumbravam uma ação premeditada do Estado contra a mobilização; e 2) para revelar a participação de halcones infiltrados do Estado.

b) O posicionamento do Estado.

Em primeiro lugar, os discursos pronunciados pelo titular do Executivo Federal e pelo general Cienfuegos deixam entrever a posição do governo mexicano não apenas diante do sumiço dos 43 estudantes, senão que se posicionou diante também das mobilizações cidadãs e, cabe dizer, usando mais uma postura ameaçadora do que conciliadora e colaborativa. Em um primeiro momento, no dia 19 de novembro de 2014, um dia antes do protesto, Enrique Peña Nieto se encontrava em um evento vinculado a um hospital em Cuautitlán Izcalli, zona metropolitana da Cidade do México. Diante do crescente escândalo da "verdade histórica", da mobilização que aconteceria e dos eventos violentos que tinham acontecido (como o ataque ao Palácio Nacional, as queimas de ônibus e a queima do Palácio de Governo de Guerrero ${ }^{367}$ por parte de normalistas), o presidente elaborou um discurso ameaçador, ostensivamente autoritário e negador da dissidência ou do pensamento que se encontre fora do projeto de nação do PRI com frases como:

\footnotetext{
“Al amparo de esta consternación social que hay por los hechos de dolor y de horror (...) hemos advertido los movimientos de violencia que, al amparo y al escudo de esta pena, pretenden hacer valer protestas que, a veces, no está claro su objetivo (...) pareciera que respondieran a un interés general de generar desestabilización, de generar desorden social y, sobre todo, de atentar contra
}

\footnotetext{
${ }^{365}$ Código Penal Federal, Libro Segundo, Título Quinto: Delitos en Materia de Vías de Comunicación y de Correspondencia, Capítulo I: Ataques a las Vías de Comunicación y Violación de Correspondencia, Artículo $170^{\circ}$ : “(...) Se impondrá de tres a veinte años de prisión y de cien a cuatrocientos días de multa, sin perjuicio de la pena que corresponda por otros delitos que cometa, al que mediante violencia, amenazas o engaño, se apodere o ejerza el control de una plataforma fija, instalaciones o servicios de navegación aérea o marítima o de aeropuertos que presten servicios a la aviación civil (...)”.

${ }^{366}$ Desiste Asamblea Ineruniversitaria de cerco al AICM - Redacción El Universal, Op.Cit.

367 Após evacuarem os funcionários, estudantes normalistas atearam fogo no Palácio de Governo do estado de Guerrero no marco das protestas nacionais pelo sumiço dos 43 estudantes de Ayotzinapa - Queman el Palacio de Guerrero - Rogelio Agustín ESTEBAN em Milenio, publicado em 13 de outubro de 2014, disponível em: http://www.milenio.com/estados/Salen-trabajadores-Palacio-Gobierno_0 389961302.html - acessado em maio de 2016.
} 
el proyecto de nación que hemos venido impulsando." Fragmento do discurso do presidente Enrique Peña Nieto, 19 de novembro de $2014^{368}$.

O presidente deixa entender que considera ilegítimos aos movimentos que surgiram a partir do sumiço dos 43 estudantes e, não apenas isso, senão que os acusa de serem utilizados por forças alheias ao governo para desestabilizar ao Estado mexicano. Essa afirmação resulta altamente perigosa porque não é mais do que o Estado deslegitimando toda e qualquer oposição que possa existir acusando-a de "desestabilizadora" e efetivamente criminalizando o protesto social. Confirma a proibição do -direito à rebelião- da cidadania por parte de um Estado autoritário sob a máscara de democrático. Criminaliza e deslegitima aos protestos adjudicando-lhes a etiquete de "desestabilizadores", o qual significa que são uma ameaça à integridade da federação e, portanto, sustentado em documentos como o Plan Sectorial de Defensa Nacional 2013-2018, documento já mencionado e que afirma que a proteção da federação diante de ameaças internas ou externas é labor fundamental das forças armadas junto com a misteriosa Operación Dragon e o Plan de Operaciones de la Base el Rosario, emanado dos documentos anteriores e que estabelece a diretriz de ação de "abater criminosos". Fazendo a relação do discurso com os documentos oficiais e as diretrizes estabelecidas, o presidente está decididamente legitimando e pseudo-legalizando o ataque com força de fogo contra a população civil dissidente do "projeto nacional".

O discurso do presidente continua ameaçador e na tentativa de oferecer um rosto forte do Estado mexicano, afirma que:

\footnotetext{
"No nos vamos a detener. Pareciera que algunas voces, unidas a esta violencia y a esta protesta, algunas de ellas fueran aquellas que no comparten este proyecto de nación; que quisieran que el país no creciera, que quisieran que el país frenara su desarrollo". Fragmento do discurso do presidente Enrique Peña Nieto, 19 de novembro de $2014^{369}$.
}

O posicionamento de Peña Nieto é simples: se não estão com nós, estão contra nós. Seguindo a absoluta essência do PRI, o partido da revolução, toda dissidência, toda voz contrária e toda oposição são a contrarrevolução imediatamente demonizada e legitimada, pela própria essência da contraposição entre revolução e contrarrevolução, para ser exterminada.

\footnotetext{
${ }^{368}$ EPN. No dentendrán el proyecto de nación; acusa violencia para desestabilizar - Enrique SÁNCHEZ, publicado em 19 de novembro de 2014 em EXCELSIOR, disponível em: http://www.excelsior.com.mx/nacional/2014/11/19/993055 - Acessado em maio de 2016. ${ }^{369}$ Ídem.
} 
As ameaças continuaram na manhã do dia 20 de novembro antes do começo da mobilização social durante um evento de condecoração militar ${ }^{370}$ no marco do aniversário da Revolução Mexicana no campo militar Marte, no coração da Cidade do México. Rodeado de soldados e autoridades militares, o presidente afirmou que:

"El Gobierno de la República no cejará en sus esfuerzos por hacer que impere el Estado de derecho y la justicia en todo el territorio nacional (...) es inaceptable la violencia cualquiera que sea su origen (...) los mexicanos décimos no a la violencia y rechazamos categóricamente cualquier intento por provocarla o alentarla". Fragmentos do discurso do presidente Enrique Peña Nieto, 20 de novembro de $2014^{371}$.

O tom do discurso continua sendo o mesmo: se assumindo como -a nação- e do que significa ser mexicano, separando-o do Outro-indesejável que protestará na capital durante as próximas horas. Por sua vez, o general Cienfuegos, na sua função de Secretario General de la Defensa Nacional, reitera a sua lealdade ao presidente e à pátria para posteriormente advertir que:

\footnotetext{
"En el pasado los mexicanos hemos enfrentado tempos difíciles (...) la historia nos muestra que en esas situaciones hay dos caminos: el de la desunión, reflejado y marcado por la violencia, la intolerancia, la crítica infundada, el temor. Esta vía, solo lleva al fracaso nacional, al atraso social, a la frustración, a la ingobernabilidad, a la inestabilidad (...) ni la delincuencia, ni cualquier otro antagonismo podrán jamás someter a la democracia; juntos, los mexicanos con ferviente amor por México somos más para superar cualquier obstáculo, ¡unámonos para resolver los desafíos que enfrentamos!". Fragmentos do discurso do General Salvador Cienfuegos, 20 de novembro de $2014^{372}$, grifos nossos.
}

O general Cienfuegos, como qualquer militar, desborda patriotismo em cada palavra que emite, isto é um discurso conhecido das forças armadas que ainda têm ao pensamento nacionalista

\footnotetext{
${ }^{370}$ Não está demais dizer que um dos militares condecorados e promovido foi Alejandro Saavedra Hernández, o comandante da $35^{\circ}$ zona militar e responsável direto do $27^{\circ}$ Batalhão de Infantaria de Iguala, involucrados direta e indiretamente no ataque e sumiço dos 43 estudantes, isto no marco da revolta social e das negativas da SEDENA de permitir investigações e buscas nas bases militares da região - Peña ascende a jefe de zona militar de Guerrero - Jorge CARRASCO ARAIZAGA, publicado em 20 de novembro de 2014 em PROCESO, disponível em: http://www.proceso.com.mx/388302/pena-asciende-a-jefe-de-zona-militar-de-guerrero - acessado em maio de 2014.

371 'Tendrá que imperar el estado de derecho' - Redacción El Siglo de Torreón, publicado em 21 de novembro de 2014, disponível em: https://www.elsiglodetorreon.com.mx/noticia/1059737.html - acessado em maio de 2016. ${ }^{372}$ Mensaje pronunciado por el Gral. Srio. Def. Nal., CIENFUEGOS ZEPEDA, durante la Ceremonia de Imposición de Condecoraciones y Ascensos, en el marco del "CIV” Aniversario de la Revolución Mexicana, en las instalaciones del Campo Militar "Marte", D.F. - Secretaria de la Defensa Nacional, publicado em 20 de novembro de 2014, disponível em: http://www.gob.mx/sedena/prensa/20-de-noviembre-de-2014 - acessado em maio de 2016.
} 
como estandarte e se orgulham da sua lealdade e compromisso para com a nação e com o presidente civil, no caso, Enrique Peña Nieto. É importante, para nós, não esquecer que os militares, por mais nacionalismo que possam ostentar, são apenas mercenários oficializados, legitimados e pagos pelo Estado e cuja única lealdade reside nas conveniências do contexto.

Uma vez esclarecido o anterior, as palavras de Cienfuegos começam a fazer sentido além do discurso que lembra dos rituais nacionalistas de toda segunda-feira de manhã, coisa que todo estudante do sistema educativo mexicano lembrará, quando, com o abraço do frio matinal da Cidade do México, pensávamos mais em como conseguir calor e não dormir enquanto a bandeira nacional desfilava burocraticamente pelo pátio principal da escola. O discurso de Cienfuegos é uma versão adulta do martírio das segundas-feiras, só que dessa vez, vamos analisá-lo em lugar de tentar não dormir.

As palavras grifadas na citação acima apresentada, como "desunião" e "fracasso nacional", "atraso" e frustração", palavras sumamente tristes e desalentadoras, estão diretamente vinculadas à "crítica infundada" e a "qualquer outro antagonismo" ao governo, portanto oposto ao Estado e à nação mexicana. Essa crítica infundada das pessoas que "deveríamos criticar menos e trabalhar mais”, frase que muitos de nós podemos dizer que já recebemos. Em paralelo menciona que esses "antagonismos" não poderão derrotar à democracia. Além do irrisório recurso à conceitos abstratos e altamente abrangentes (como lutar pelo amor e o fim da corrupção), a ideia de -democracia- de Cienfuegos é precária, por dizer pouco, ao negar a existência de disputas e antagonismos em um sistema democrático. Talvez o roteirista oficial deveria ter escrito -democracia priísta- ou -democracia autoritária-, de essa forma faria mais sentido. Continuando, alerta que esses "antagonismos", entendidos como a normalidade de um sistema democrático saudável (não que seja o caso do México) levariam ao "fracasso", à “frustração", à “ingovernabilidade e instabilidade". De novo, se o roteirista tivesse acrescentado - ingovernabilidade e instabilidade do domínio do PRI- faria sentido. Para finalizar, general Cienfuegos lembra que estamos em desvantagem numérica diante dos "mexicanos com fervente amor pelo México" definindo o que seria um bom mexicano, ou mais ainda, o que uma pessoa tem de ser para ser mexicano. Pelo visto somos todos aqui estrangeiros no nosso próprio país.

Pode o roteiro de uma sátira do estereotipo do militar das ditaduras latino-americanas do século passado, porém, a realidade alarmante é que o Estado priísta, novamente, se assume como -a nação- e se adjudica o direito de definir quem é um cidadão exemplar, um mexicano comprometido com o desenvolvimento da nação, uma pessoa que segue certo comportamento e certo estilo de vida, o qual o faz parte do projeto nacional. Com a outra mão acusa a aqueles 
que discordam do projeto nacional imposto, os vincula com certas ideologias políticas, com certos estilos de vida e de agir na esfera pública criando um Outro-indesejável que não necessariamente é definido pela raça, pela posição socioeconômica ou pelo pensamento político, embora não esteja, tampouco, totalmente deligado do anterior. Exemplo emblemático é a tortura e assassinato do fotojornalista Rubén Espinosa ${ }^{373}$ na Cidade do México em agosto de 2015 o qual foi relacionado ao mundo das drogas e da prostituição por parte da PGR e da mídia conservadora alinhada ao regime do PRI, em uma tentativa de justificar a morte de um jornalista que tinha sido severamente crítico ao governo do priísta Javier Duarte e os constantes assassinatos de jornalistas que acontecem no estado por ele governado. A lógica é perversa e a morte vira uma consequência natural e aceitável desde que for vista desde a lente dos bons costumes do patriotismo do PRI e da culpa inerente ao catolicismo conservador enquistado no Estado $^{374}$.

c) A mobilização cidadã.

A confirmação da existência de um Estado de exceção de facto, inicialmente discursiva, se veria materializada nos acontecimentos do dia 20 de novembro e dias posteriores. O protesto foi presenciado pelo autor da presente dissertação em companhia de um amigo, os relatos estão disponíveis através de duas publicações em um blog 375 e serão referenciados como parte da narrativa do acontecido no dia 20 de novembro de 2014. O protesto se desenvolvia com tranquilidade e de maneira pacifica, Alejando Gómez, coautor do blog, ressalta a participação de cidadãos de distintos estados da república assim como organizações internacionais como AI e Greenpeace. Menciona a presença de ministros de culto de distintas organizações religiosas e até torcidas organizadas dos times de futebol da capital mexicana e o contrasta com a presença oportunista do Movimiento de Regeneración Nacional - MORENA de Andrés Manuel Lopez

\footnotetext{
${ }^{373}$ Rubén Espinosa foi encontrado morto em um apartamento da capital junto com quatro pessoas mais (mulheres todas). Tinha saído do estado de Veracruz por pressões do governo de Javier Duarte (PRI), acusado de permitir o assassinato de jornalistas na região - Conmoción por asesinato de periodista Rubén Espinosa en Ciuad de México - Redacción BBC Mundo, publicado em 20 de agosto de 2015, disponível em: http://www.bbc.com/mundo/noticias/2015/08/150802 mexico_muerte_ruben_espinosa men - acessado em maio de 2016.

${ }^{374}$ Peritaje de PGJDF revela consumo de cocaína y mariguana em ejecutados de Narvarte - Redaccion SDP Noticias, publicado em 13 de agosto de 2015, disponível em: http://www.sdpnoticias.com/local/veracruz/2015/08/13/peritaje-de-pgjdf-revela-consumo-de-cocaina-ymariguana-en-ejecutados-de-narvarte - acessado em maio de 2016.

375100.000 Desestabilizadores - Alejandro GÓMEZ, publicado em 22 de novembro de 2014 em LA SERPIENTE DESPLUMADA, disponível em: https://laserpeintedesplumada.wordpress.com/2014/11/22/100000desestabilizadores/ - acessado em 2014 - e - Los Halcones del Régimen (Crónica del \#20NovMX) - Erick Andrés REYES TRIVILINO, publicado em 21 de novembro de 2014 no mesmo portal, disponível em: https://laserpeintedesplumada.wordpress.com/2014/11/21/los-halcones-del-regimen-cronica-del-20novmx/ _ autor do texto.
} 
Obrador $^{376}$. A presença de esta diversidade se traduz como a presença da sociedade per se sem estar limitada apenas a parcelas especificas da população e, portanto, deixa entrever a universalidade do tema em questão: a vulnerabilidade da População Civil (maiúsculas intencionais) diante do NarcoEstado.

Uma situação que chama a atenção foi a apropriação do termo "desestabilizadores" usada de maneira pejorativa pelo presidente Peña Nieto pelas pessoas como uma forma de reafirmação dos cidadãos que protestavam, ou como afirma Gómez, se assumem como desestabilizadores do "projeto priísta" mediante a organização crítica e politicamente ativa.

\footnotetext{
"No queremos asustarlo, pero no estamos contando a quienes se manifestaron en otras ciudades, en otros países y en redes sociales, porque si para usted 100.000 es un grupo minúsculo de desestabilizadores, a la suma de todos los anteriores usted la podría considerar entonces una rebelión." Alejandro Gómez - 100.000 desestabilizadores.
}

Em outras cidades do país registraram-se toma de Congressos locais junto com ataques a prédios públicos e confrontos com os distintos batalhões de choque ${ }^{377}$. Na Cidade do México, por sua vez, se observou desde as primeiras horas do dia a mobilização do Exército mexicano em torno do evento que aconteceria no campo militar Marte acima referido, porém, chamou a atenção a presença de militares com vestimenta civil, alguns com o rosto coberto, dentro dos caminhões de transporte do exército, situação que foi documentada amplamente nas redes sociais e jornais online ${ }^{378}$, a SEDENA rapidamente desmentiu as acusações ${ }^{379}$. As suspeitas foram levantadas pelo uso histórico de halcones por parte do Estado como infiltrados nas mobilizações sociais que têm como função começar o confronto com as forças de segurança e assim justificar o ataque como legítima defesa. No contexto das mobilizações por Ayotzinapa, os halcones eram acusados de utilizar casacos ou distintas roupas para ocultar o rosto, isto favorecia a sua infiltração entre os grupos de anarquistas, os quais virariam o bode expiatório

\footnotetext{
${ }^{376}$ A presença de MORENA é considerada pelo autor como uma demonstração do oportunismo dos partidos políticos tentando obter lucro de uma tragédia, no caso, o partido que nasceu de uma cisma no PRD após a saída de López Orador do mesmo.

${ }^{377}$ Marchan miles en el país en jornada por Ayotzinapa - Redacción Proceso, publicado em 20 de novembro de 2014, disponível em: http://www.proceso.com.mx/388418/marchan-miles-en-el-pais-en-jornada-por-ayotzinapa acessado em maio de 2016.

${ }^{378}$ Exhiben en redes a presuntos militares vestidos de civil - Redacción RED POLÍTICA, publicado em 20 de novembro de 2014, disponível em: http://www.redpolitica.mx/metropoli/exhiben-en-redes-presuntos-militaresvestidos-de-civil - acessado em maio de 2016.

379 SEDENA rechaza que militares vestidos de civil hayan participado em distúrbios del \#20NovMX - Jorge CARRASCO ARAIZAGA, publicado em 26 de novembro de 2014, disponível em: http://www.proceso.com.mx/389076/sedena-rechaza-que-militares-vestidos-de-civil-hallan-participado-endisturbios-del-20novmx - acessado em maio de 2016.
} 
da grande mídia ${ }^{380}$ e do Estado para: 1) deslegitimar aos movimentos e organizações anarquistas; e 2) justificar a intervenção policial nos protestos.

$\mathrm{O}$ anterior levanta as primeiras suspeitas durante o confronto que aconteceu nas imediações do AICM que, como foi mencionado, seria objeto de um bloqueio por parte da AI que foi subitamente cancelado. Nas proximidades do aeroporto apareceu um pequeno grupo de pessoas de rosto coberto que começariam um confronto com o batalhão de choque sem motivos aparentes $^{381}$. Afirmar ou negar no cenário anterior é arriscado, porém, as suspeitas continuam presentes: por que diante do anúncio de cancelar o bloqueio ao AICM, esse grupo se fez presente? Sabendo que ninguém mais iria comparecer, era evidente que a desvantagem numérica diante do batalhão de choque seria muita como para pensar sequer em um confronto, o qual, mesmo assim aconteceu. A possibilidade de a mensagem ter sido enviada subitamente pode levantar a questão de que foi apenas recebida pela comunidade legitimamente ligada à AIU enquanto os grupos infiltrados foram tomados de surpresa e não ficaram sabendo; ou o confronto foi proposital para criar um cenário tenso desde cedo que justificaria o agir do batalhão mais tarde; ou simplesmente foi um grupo que sinceramente não ficou sabendo do cancelamento do bloqueio. Porém, fica a dúvida sobre iniciar um confronto estrategicamente contraproducente e sem lógica nenhuma por mais que se tentasse pensar perversamente.

Por outro lado, a marcha continuaria de forma pacífica até chegar à praça ${ }^{382}$ central da Cidade do México e começaria um pronunciamento por parte dos pais dos 43 estudantes desaparecidos enquanto os manifestantes continuavam chegando na praça. Coincide com a queima de uma efigie gigante do presidente Peña Nieto ${ }^{383}$ o qual resulta sintomático da percepção cidadã da simbiose existente entre violência, narcotráfico e Estado. Perto do final da mobilização começa a ficar visível a crescente presença de homens de rosto coberto na praça principal os quais vão

\footnotetext{
${ }^{380}$ Anarquistas causan destrozos en marcha por Ayotzinapa - Azteca Noticias, publicado em 26 de setembro de 2015, disponível em: http://www.aztecanoticias.com.mx/notas/mexico/231925/anarquistas-causan-destrozos-enmarcha-por-ayotzinapa - acessado em maio de 2016.

${ }^{381}$ Granaderos y encapuchados se enfrentan cerca del Aeropuerto - Mathieu TOURLIERE em PROCESO, publicado em 20 de novembro de 2014, disponível em: http://www.proceso.com.mx/388304/encapuchados-sedirigen-al-aicm-arriban-al-df-maestros-de-guerrero - acessado em maio de 2014.

${ }^{382}$ O Zócalo e uma praça de armas que segue o padrão de urbanismo colonial espanhol. É quadrangular e encontrase flanqueada pela Catedral Metropolitana ao norte, os prédios de governo do Distrito Federal ao sul, o Palácio Nacional ao leste e um par de hotéis ao oeste. Possui 9 ruas que dão acesso ou saída: 1) 5 de mayo, 2) República de Brasil, 3) 16 de septiembre, 4) 5 de febrero, 5) 20 de noviembre, 6) Pino Suárez, 7) Corregidora, 8) Moneda, e 9) Madero, destinada unicamente para pedestres.. As ruas laterais e dos fundos do Palácio Nacional encontravamse sob controle da polícia no \#20NovMX e foi de onde se produz o ataque.

${ }^{383}$ Queman figura de Peña Nieto en el Zócalo - Redacción 24 HORAS, publicado em 20 de novembro de 2014, disponível em: http://www.24-horas.mx/queman-figura-de-pena-nieto-en-el-zocalo-fotos/ - acessado em maio de 2016.
} 
se aproximando do Palácio Nacional e ao redor das 21:30 horas começam a jogar bombas molotov e explosivos contra os policiais que resguardavam o palácio. Cabe mencionar que por motivos de segurança após a tentativa de incêndio e invasão contra o Palácio Nacional umas semanas antes, este encontrava-se severamente resguardado e com as luzes centrais desligadas, o qual dificultava perceber a presença de militares e policiais nessa zona. Posteriormente, batalhões inteiros da polícia auxiliar e da federal começam a entrar pela rua de Corregidora na parte lateral do palácio. ${ }^{384}$

Os relatos da imprensa fazem ênfase na provocação de um punhado de indivíduos contra as forças de segurança e a invasão massiva à praça que o batalhão de choque considerou como o mecanismo de ação adequado ${ }^{385}$. Enquanto os confrontos com fogo e bombas aumentam frente ao Palácio Nacional, os batalhões policiais continuam entrando incessantemente pelas ruas laterais da praça:

\begin{abstract}
"Entonces vemos como comienza una desbandada en esa esquina humeante del Zócalo, como un tsunami de carne humana arrasándolo todo desde el costado de Corregidora y en dirección al vértice de Brasil y 5 de mayo (...) centenares de elementos de la Policía Federal y del DF arrasan en cosa de minutos y como una avalancha con familias, niños, ancianos, vendedores ambulantes, turistas, periodistas, fotógrafos, observadores casuales, estudiantes y jóvenes. Lejos, muy lejos del núcleo del disturbio original (...) La ofensiva ocurre sin aviso, en cuestión de segundos y a base de fuerza, extinguidores, toletes, escudos usados contra el canto como armas y gases lacrimógenos (...)". Tryno Maldonado - Coreografia Infernal. Crónica del desaljo del Zócalo al terminar la marcha \#20NovMX \#Ayotzinapa. ${ }^{386}$
\end{abstract}

Além do evidente uso ostensivo da força como mecanismo de repressão de um Estado desesperado diante de um protesto massivo no coração da cidade, é necessário denunciar a irresponsabilidade de invadir uma praça lotada de forma violenta pelo perigo de criar uma debandada humana, a qual, quase aconteceu devido a que no momento da invasão, das nove ruas que dão acesso ou saída da praça, duas estavam ocupadas pela polícia (Moneda e Corregidora) de onde a invasão policial se originou empurrando aos manifestantes para o

\footnotetext{
${ }^{384}$ Se enfrentan encapuchados y granaderos en el Zócalo; hieren a fotógrafo de Proceso - José GIL OLMOS em PROCESO, publicado em 20 de novembro de 2014, disponível em: http://www.proceso.com.mx/388413/seenfrentan-encapuchados-y-granaderos-en-el-zocalo - acessado em maio de 2016.

${ }^{385}$ Coreografía Infernal. Crónica del desalojo del Zócalo al terminar la marcha \#20NovMX \#Ayotzinapa - Tryno MALDONADO, publicado em 22 de novembro de 2014 em EMEEQUIS, disponível em: http://www.mx.com.mx/2014-11-22/coreografia-infernal-cronica-del-desalojo-del-zocalo-al-terminar-la-marcha-20novmxayotzinapa-por-tryno-mal/ - acessado em maio de 2016. 386 Ídem.
} 
extremo oeste da praça a qual oferece apenas três saídas: 16 de septiembre, um vértice que alguns metros depois se divide em República de Brasil e Avenida 5 de mayo, e Madero, uma rua estreita destinada apenas para pedestres; das anteriores, apenas Madero e 5 de Mayo foram habilitadas para permitir a entrada dos manifestantes e, no momento da invasão, ainda haviam pessoas tentando entrar na praça. O perigo se auto explica ${ }^{387}$.

O resultado reportado oficialmente da invasão à praça por parte das forças do Estado foi de 31 pessoas detidas, policiais com queimaduras no rosto e seis pessoas lesionadas. Dos 31 detidos, 16 foram consignados ao MP por delitos não graves enquanto 15, número posteriormente reduzido a 11 e dos quais se falarão a continuação, foram consignados por delitos da ordem federal ${ }^{388}$. Uma questão bastante sintomática foi a criminalização imediata dos detidos por parte da grande mídia usando o termo "anarquista" como paliativo. Caso emblemático é o de Alejandro Villalvazo de TV Azteca o qual, no dia 21 de novembro às 8:46 horas da manhã publicou na sua conta de Twitter ${ }^{389}$ que 31 "anarcos" tinham sido presos, assumindo o papel de comunicador, juiz, jurado e carrasco com menos de 12 horas após os incidentes no caso de "justiça expedita” mais eficiente da história.

d) O escarmento do regime.

Nos dias posteriores se levantaria a questão da detenção arbitrária dos indivíduos acusados de delitos graves da ordem federal após um protesto pacífico que terminou com um ato de repressão desproporcional em um contexto de fratura social entre a população e o Estado. Após os eventos, o então titular da Secretaría de Seguridad Pública del Distrito Federal - SSPDF, Jesús Rodríguez Almeida, exclamou orgulhoso que os elementos tanto federais como da capital hajam agido com "[...] gran valor, gallardía, responsabilidad y sobre todo restablecieron el orden público le guste a quien le guste" ${ }^{390}$. É uma afirmação interessante se considerarmos não apenas a estratégia de invasão que quase derivou em uma debandada sem controle, senão que houve reportes que afirmavam que as ruas de saída do Zócalo teriam ficado com as luzes

\footnotetext{
387 Ídem.

38831 detenidos y al menos seis lesionados, saldo de protestas por Ayotzinapa - Redacción PROCESO, publicado em 21 de novembro de 2014, disponível em: http://www.proceso.com.mx/388439/31-detenidos-y-al-menos-seislesionados-saldo-de-protestas-por-ayotzinapa - acessado em maio de 2016.

389 "Saldo \#20NovMx: 31 anarcos detenidos, 150 MDP en perdidas (sic), pero lo más importante; miles que por voluntad y en apoyo gritan \#YaMeCanse (sic)”. Disponível na conta pessoal de Villalvazo (@VILLALVAZO13) em: https://twitter.com/villalvazo13/status/535806540645941248 - acessado em maio de 2016.

${ }^{390}$ Los granaderos demostraron "gallardía, responsabilidad” en \#20NovMx, dice jefe de la policía del DFRedacción ANIMAL POLÍTICO, publicado em 24 de novembro de 2014, disponível em: http://www.animalpolitico.com/2014/11/los-policias-del-df-demostraron-valor-gallardia-responsabilidaddurante-20novmx-rodriguez-almeida/ - acessado em maio de 2016.
} 
desligadas propositalmente e o bloqueio por parte da polícia de outras ruas de saída ${ }^{391}$, isto em conjunto com denúncias do agir violento e indiscriminado da polícia sem diferenciar entre agressores e observadores circunstanciais (famílias incluídas) ${ }^{392}$.

O anterior é uma carência processual gravíssima e que anula qualquer tentativa de legitimar as detenções feitas pela polícia se não existia uma ordem de detenções dirigida contra algum grupo de agressores identificados plenamente, e pior ainda, ao ser uma serie de agressões indiscriminadas contra pessoas em clara situação de assimetria (i.e., uma criança ou um idoso), e que além de incriminar à cadeia de comando, abre uma questão obvia que não precisa de cientificidade: se um policial é capaz de agredir crianças ou idosos é difícil considerar que teria o critério para fazer detenções e adjudicar crimes graves da ordem federal como tentativa de homicídio, formação de quadrilha, terrorismo e motim, isto é, os delitos pelos quais foram detidos os manifestantes no dia 20 de novembro.

O anterior foi denunciado pela CNDH no relatório e recomendação 16/2015 393 na qual acusa de: I) elementos da SSPDF, não seguiram as funções de segurança pública e princípios de atuação das normas e critérios nacionais e internacionais e, portanto, vulneraram o direito à manifestação, à liberdade de expressão e de reunião; II) foram detidas arbitrariamente 14 pessoas (um menor incluído) nas imediações do AICM sem respeitar os requisitos legais ao não consigná-los imediatamente às autoridades correspondentes; III) agrediram física e verbalmente aos detidos tanto quanto a outros participantes do protesto e exerceram um uso indevido da força pública; e IV) não respeitaram o procedimento de cadeia de custódia dos objetos apresentados como evidência e que incriminavam as pessoas detidas, violando assim o direito à liberdade pessoal em relação com o devido processo e as garantias jurídicas.

\footnotetext{
391 “(..) 'y cuando yo y mi familia quisimos desplazarnos por la calle de Madero nos dimos cuenta que la calle estaba totalmente oscura, las autoridades apagaron las luces de este lugar durante el operativo (...) decidimos dar vuelta y buscar salir por la calle 5 de mayo (paralela), pero la policía nos impidió el paso' (...)”. \#20NovMx: la policía agredió a familias ... con "valor y gallardía" - Paris MARTINEZ em ANIMAL POLÍTICO, publicado em 25 de novembro de 2014, disponível em: http://www.animalpolitico.com/2014/11/20novmx-la-policiaagredio-familias-con-valor-y-gallardia/ - acessado em maio de 2016.

392 "Tras esta agresión, Juan Martín, su esposa y hermanas, resultaron con diversos moretones en el cuerpo, y su madre, tras ser arrojada al suelo por los granaderos, quedó con una lesión en el tobillo. El niño de tres años no sufrió lesión alguna, aunque sí quedó 'con temor a los policías". Ídem.

393 Recomendación 16/2015: Violaciones a los derechos humanos cometidas durante la protesta por la desaparición de los 43 normalistas de Ayotzinapa, que se realizó el día 20 de noviembre de 2014 - CNDH, publicado em: 17 de dezembro de 2015, disponivel no portal da CNDH atravéz de: http://cdhdfbeta.cdhdf.org.mx/wp-content/uploads/2015/12/reco_1615.pdf - acessado em maio de 2016.
} 
Em paralelo, Mathieu Tourliere para a Revista Proceso ${ }^{394}$, denuncia o traslado imediato de 11 detidos durante a invasão ao Zócalo para a SEIDO sem a autoridade ter esclarecido os motivos de serem trasladados à sede de um organismo de investigação criminal federal encontrando inconsistências processuais como, por exemplo, o fato de 13 integrantes do CNDH relatarem que os 11 foram detidos em situações espaço-temporais distintas, enquanto policiais federais afirmaram que foram todos detidos ao mesmo tempo para evitar o homicídio de um colega policial. O mesmo Tourliere em outra publicação ${ }^{395}$ aponta as falhas processuais documentadas pela $\mathrm{CNDH}$ que se configuram como atentados diretos ao devido processo como as denúncias de falsos depoimentos ou bem, alterações dos mesmos. Menciona também a incomunicação à que foram sometidos os detidos assim como os depoimentos forçados com advogados de ofício para conformar a pasta PGR/SEIDO/UETIA/194/2014 ${ }^{396}$ na qual constam os delitos de: a) Homicídio em grau de tentativa; b) Formação de quadrilha; e c) Motim. Ao anterior se suma o traslado a prisões federais fora da Cidade do México ${ }^{397}$.

Se bem não pode se falar de uma desaparição forçada já que a localização dos detidos era conhecida apesar do traslado da praça do Zócalo para prisões federais fora da capital. No entanto, configura sim um ato de terrorismo de Estado através das forças de segurança com cumplicidade do Poder Judiciário da Federação ao violar o devido processo dos detidos, a incomunicação à que foram sometidos e o fato de trasladá-los a prisões federais em clara ação punitiva mais do que preventiva, punição que não tinha sido resultado de nenhum processo nem julgamento.

\footnotetext{
${ }^{394}$ Actas de la CNDH y testigos evidencian mentiras de la Policía en detenciones del \#20NovMx - Mathieu TOURLIERE em PROCESO, publicado em 30 de novembro de 2014, disponível em: http://www.proceso.com.mx/389462/actas-de-la-cndh-evidencian-mentiras-de-la-policia-en-detenciones-del20novmx - acessado em maio de 2016.

395 Acusan amenazas, incomunicación y presiones contra 11 estudiantes detenidos por \#20NovMx - Mathieu TOURLIERE em PROCESO, publicado em 22 de novembro de 2014, disponível em: http://www.proceso.com.mx/388537/acusan-amenazas-incomunicacion-y-presiones-contra-11-estudiantesdetenidos-el-jueves-20 - acessado em maio de 2016.

${ }^{396}$ Através da nota informativa DGCS/NI: 157/2014 do Consejo de la Judicatura Federal - CJF do Poder Judicial de la Federación na qual consta o início do processo penal contra 11 pessoas: três mulheres e oito homens, um deles estrangeiro. Disponível em: https://www.cjf.gob.mx/documentos/notasInformativas/docsNotasInformativas/2014/notaInformativa157.pdf acessado em maio de 2016.

397 "A raíz de estas acusaciones, el pasado sábado a las siete de la mañana los detenidos fueron trasladados del edificio de la Subprocuraduría en Investigaciones de Delincuencia Organizada (SEIDO) a los penales de Tepic, en Nayarit, en el caso de las tres mujeres, y al de Villa Aldama, en Veracruz, los hombres". - "iTodos somos compas!", responden a PGR n marcha por detenidos del \#20NovMx - Mathieu TOURLIERE em PROCESO, publicado em 25 de novebro de 2014, disponível em: http://www.proceso.com.mx/388998/todos-somos-compasresponden-a-pgr-en-marcha-por-detenidos-del-20novmx - acessado em maio de 2016.
} 
Ressalta também o caso de Laurence Maxwell, cidadão chileno e estudante de doutorado em Letras da UNAM, que se encontrava entre os 11 detidos e o qual precisou da intervenção diplomática $^{398}$ do seu país de origem diante do atropelamento dos seus direitos pelo aparelho judiciário do Estado mexicano. A situação para o estudante chileno era particularmente preocupante diante da possibilidade de ser condenado a cumprir pena em uma prisão mexicana por delitos federais graves fabricados como medida de terrorismo de Estado para sufocar um foco de instabilidade e insurreição social, isto no pior dos casos, ou de ser sujeito do infame artigo $33^{\circ}$ da Constituição mexicana ${ }^{399}$ que faculta ao Poder Executivo da União de expulsar de território nacional, prévia audiência (não julgamento), a qualquer pessoa estrangeira e que os proíbe de participarem de qualquer jeito nos assuntos políticos do país (inclusive protestos) sob pena de deportação, o qual, dadas as circunstancias seria o melhor cenário possível.

No dia 29 de novembro de 2014, nove dias após a sua detenção, os 11 indivíduos foram declarados inocentes e se pediu a sua liberdade imediata por falta de evidências para acreditar os delitos de homicídio em grau de tentativa, motim e formação de quadrilha segundo consta na resolução do Juzgado decimoséptimo de Distrito en el Estado de Veracruz da causa penal $45 / 2014^{400}$, documento que reconhece a falta de evidência física materializada em bombas molotov e, pedras e paus, evidência que nunca foi assegurada nem apresentada pelos policiais dos quais também reconhece a existência de depoimentos contraditórios. O juiz não viu elementos de formação de quadrilha e não reconheceu o delito de motim, absolvendo assim aos acusados sob o princípio de presunção de inocência.

O caso apresentado contra os 11 detidos pelos delitos mencionados, particularmente o de motim, resulta irrisório e seria inocente acreditar que a o Estado pensava de fato efetivar o processo e conseguir a condenação e prisão dos inculpados. A própria espectacularidade das acusações o confirma. Em momento nenhum a intenção de acusá-los de motim e enviá-los a prisões federais de maneira "preventiva" tinha como objetivo levar o caso até as suas últimas consequências, isso teria sido criar mártires e presos políticos. O objetivo teria sido mandar

\footnotetext{
398 ¿Quién es Laurence Maxwell, el detenido en México que preocupa a Chile?” - Paula MOLINA em BBC Mundo, publicado em 26 de novembro de 2014, disponível em: http://www.bbc.com/mundo/noticias/2014/11/141125_protestas_mexico_detencion_maxwell_lav - acessado em maio de 2016.

399 Artículo 33: “(...) El Ejecutivo de la Unión, previa audiencia, podrá expulsar del territorio nacional a personas extranjeras con fundamento en la ley (...) Los extranjeros no podrán de ninguna manera inmiscuirse en los asuntos políticos del país."

${ }^{400}$ Resolução resgatada da nota -Resolución completa del juez que ordenó la liberación de detenidos el 20 NovMx - Gustavo CASTILLO GARCÍA em LA JORNADA, publicado em 29 de novembro de 2014, disponível em: http://www.jornada.unam.mx/ultimas/2014/11/29/resolucion-completa-del-juez-que-ordeno-la-liberacion-dedetenidos-el-20novmx-2864.html - acessado em maio de 2014.
} 
uma mensagem sobre o que poderia acontecer por fazer parte de protestos, no caso, passar nove dias em confinamento solitário em uma prisão federal após ter sido detido e golpeado por policiais seria a punição e, além do mais, advertia que continuaria acontecendo já que nenhuma autoridade seria alvo de investigações pelas detenções arbitrárias. Isto em poucas palavras pode ser considerado, como foi mencionado, terrorismo do Estado para sufocar o foco de descontento e de mobilização, - o Estado pode te prender, te golpear, te acusar de terrorismo sem provas sabendo que no final serás absolvido, mas, por enquanto, uma semana de prisão federal te espera-.

Durante o mês de novembro de 2014 aconteceriam alguns eventos que confirmariam a campanha de intimidação das forças estatais contra o foco de mobilização encarnado nos estudantes e, tal como em 1968, o foco seria o campus principal da UNAM. As tensões ao redor do campus universitário haviam estado escalando desde o protesto do dia 5 de novembro de 2014, também parte das mobilizações da Acción Global Ayotzinapa, quando indivíduos de rosto coberto aproveitaram a concentração que acontecia no centro da cidade para agir no campus principal da UNAM (localizado na zona sul da Cidade do México). Os indivíduos teriam detido um Metrobús ${ }^{401}$ na Avenida dos Insurgentes na zona que fica entre o Espacio Escultórico, o Estadio Olímpico Universitario - EOU e a Reitoria (zona de vegetação densa), evacuado aos passageiros e motorista para posteriormente colocar a unidade atravessada bloqueando a avenida em direção sul-norte e atear fogo nela; um confronto com o batalhão de choque aconteceria posteriormente ${ }^{402}$. Este incidente provocaria a incursão de agentes de segurança no campus da UNAM em horário noturno (semelhanças com o agir do Exército) para deter arbitrariamente às primeiras pessoas que aparecessem. Para azar de Sergio Pérez Landero e Luis Fernando Sotelo Zambrano, foram eles que apareceram e seriam trasladados imediatamente ao Reclusorio Sur (Prisão Sul) da Cidade do México sob cargos de ataques às vias de comunicação e à paz pública com modalidade de quadrilha para posteriormente serem liberados por falta de evidência e por um vídeo que os colocava no Instituto de Biologia ao momento da queima do Metrobús ${ }^{403}$.

\footnotetext{
${ }^{401}$ Semelhante à Rede Integrada de Transporte - RIT de Curitiba.

402 Encapuchados prenden fuego a unidad de Metrobus frente a CU - Mirna SERVÍN em LA JORNADA, publicado em 05 de novembro de 2014, disponível em: http://www.jornada.unam.mx/ultimas/2014/11/05/encapuchados-prenden-fuego-a-unidad-de-metrobus-frente-acu-950.html, acessado em maio de 2016.

${ }^{403}$ Autoridades liberan a alumno de la UNAM; consignan a joven tras quema de Metrobús - Redacción SIN EMBARGO, publicado em 6 de novembro de 2014, disponível em: http://www.sinembargo.mx/06-11-

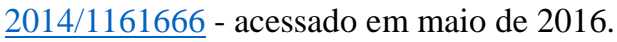


Um segundo incidente ${ }^{404}$ aconteceria dias antes do \#20NovMx, porém, em um momento no qual os movimentos estudantis tinham tomado a vanguarda das mobilizações. Durante uma assembleia fora da Facultad de Filosofía y Letras - FFyL no campus de Ciudad Universitaria - CU, testemunhas reportam um carro do qual desceram pessoas vestidas de civis os quais, relatam, começaram a tirar fotografias dos estudantes para posteriormente abrir fogo ao serem questionados pelos presentes atingindo a um aluno na perna e causando a morte de um cachorro propriedade dos estudantes $^{405}$. Um dos agressores, Luis Javier Aguiñaga Savedra, deixou cair a cédula de identidade da Procuraduría General de Justicia - PGJ ${ }^{406}$. Segundo a dependência, os policiais encontravam-se fazendo uma diligencia pelo suposto roubo de um celular no campus, o que não explicam é a clandestinidade, a improbabilidade e as coincidências: policiais vestidos de civil sem nenhuma identificação visível, armados e tirando fotografias no mesmo lugar e momento da realização de uma assembleia estudantil para planejar as mobilizações do \#20NovMx, isto sem esquecer da veemência e o compromisso da dependência e dos seus agentes para investigar o roubo de um celular.

O ataque contra os estudantes derivou em um confronto ${ }^{407}$ entre os mesmos e o batalhão de choque após os estudantes terem fechado a rua que passa pela frente da FFyL e da avenida dos Insurgentes que atravessa o campus transversalmente para posteriormente atear fogo no carro utilizado pelos policiais que atiraram mais cedo ${ }^{408}$. Do anterior é importante lembrar que a UNAM possui o qualificativo de -Autônoma- no seu nome por um motivo: tem a liberdade e independência absoluta do Estado para definir o seu próprio governo, estatutos e linhas de pensamento, assim como o uso livre e sem condicionantes, além das que a própria universidade considerar, do orçamento recebido, fazendo-a independente até mesmo do ingresso das forças de segurança do Estado desde que não exista motivo legal ou explicito. $\mathrm{O}$ ataque aos estudantes

${ }^{404}$ Vídeo do incidente disponível em: http://www.eluniversaltv.com.mx/video/metropoli/2014/video-capto-apolicia-que-disparo-a-estudiantes-adentro-de-la-unam - publicado em 15 de novembro de 2014, acessado em maio de 2016.

${ }^{405}$ Hieren de bala a estudiante en $C U$; el agresor, presunto miembro de la PGJ - Fernando CAMACHO em LA JORNADA, publicado em 15 de novembro de 2014, disponível em: http://www.jornada.unam.mx/ultimas/2014/11/15/estudiante-de-la-unam-recibe-disparo-al-parecer-de-unelemento-de-la-pgjdf-3862.html - acessado em maio de 2016.

${ }^{406}$ Policía asegura que disparó al aire en el campus de la UNAM - Josefina QUINTERO M. em LA JORNADA, publicado em 15 de novembro de 2014, disponível em: http://www.jornada.unam.mx/ultimas/2014/11/15/policiaasegura-que-disparo-al-aire-en-el-campus-universitario-5897.html - acessado em maio de 2016.

407 Agreden a policías en CU; reportan 3 uniformados lesionados - Fanny RUIZ-PALACIOS em EL UNIVERSAL, publicado em 15 de novembro de 2014, disponível em: http://archivo.eluniversal.com.mx/ciudadmetropoli/2014/reportan-3-policias-lesionados-en-nueva-trifulca-en-cu-1054516.html - acessado em maio de 2016.

408 Policías resguardan Insurgentes tras incendio de auto - Fanny RUIZ-PALACIOS em EL UNIVERSAL, publicado em 15 de novebro de 2014; disponível em: http://archivo.eluniversal.com.mx/ciudadmetropoli/2014/policias-resguardan-insurgentes-tras-auto-incendiado-1054529.html - acessado em maio de 2016. 
foi um atentado direto contra a autonomia da universidade consagrada na legislação mexicana e o confronto derivado pelo atentado emana de uma ilegalidade original. Porém, os ataques à autonomia universitária são comuns por parte do discurso conservador, inimigo declarado da universidade pública, que a considera um pretexto para proteger maconheiros e ideologias subversivas. Por sua vez, o Estado desafia à autonomia universitária como forma de intimidação direta ou indireta, lembrando a emblemática invasão e ocupação da UNAM por parte do Exército Mexicano durante o conflito estudantil de 1968.

Finalmente, após o \#20NovMx e as detenções arbitrarias mencionadas, a polícia do Distrito Federal começaria a entrar clandestinamente na UNAM até que no dia 28 de novembro de 2014, nas imediações do campus, levariam a cabo a detenção arbitrária e ilegal ${ }^{409}$ do estudante Sandino Bucio Dovalí da FFyL o qual foi interceptado por um carro civil e subido pela força por pessoas sem farda nem identificação. Duas horas depois apareceria na SEIDO e, após pressão estudantil e da UNAM, seria liberado já que, afirma a dependência, foi unicamente trasladado para prestar depoimento sobre os acontecimentos do protesto dos dias anteriores ${ }^{410}$. Ressalta também o caso de Jacqueline Santana López e Bryan Reyes Rodríguez os quais foram interceptados da mesma forma cinco dias antes do \#20NovMx e acusados de roubo a um policial federal utilizando uma faca de cozinha. Coincide que ambos seriam ativistas involucrados diretamente com o movimento \#YoSoy132 e as mobilizações de Ayotzinapa; seriam liberados por falta de evidência oito meses depois da sua detenção ${ }^{411}$.

Os eventos anteriores levariam ao estabelecimento de um sítio e plantão do batalhão de choque nas duas entradas principais do campus principal da UNAM, isto é, as entradas norte e sul da Avenida dos Insurgentes seriam ocupadas ostensivamente por várias camionetes, caminhões e viaturas do batalhão em clara atitude de intimidação em conjunto com as detenções arbitrárias de estudantes identificados como ativistas nas mobilizações acontecidas. Sabendo que a opinião pública e a sociedade encontrava-se em estado de alerta, o governo mexicano não poderia agir abertamente e apelou a pretextos pseudo-legais para realizar detenções que, como foi

\footnotetext{
${ }^{409}$ Denuncian otro "levantón" de estudiante de la UNAM; estaría en la SEIDO - Mathieu TOURLIERE em PRCOESO, publicado em 28 de novembro de 2014, disponível em: http://www.proceso.com.mx/389306/denuncian-otro-levanton-de-estudiante-de-la-unam-estaria-en-la-seido _ acessado em maio de 2016.

${ }^{410}$ La PGR declara a Sandino Bucio libre de cargos - Fernando CAMACHO SERVIN e Gustavo CASTILLO em LA JORNADA, publicado em 28 de novembro de 2014, disponível em: http://www.jornada.unam.mx/ultimas/2014/11/28/secuestran-a-estudiante-de-la-unam-y-activista-de-yosoy1322602.html - acessado em maio de 2016.

${ }^{411}$ Liberan a Jacqueline y Bryan... ocho meses después - Angélica Jocelyn SOTO em PROCESO, publicado em 10 de julho de 2015, disponível em: http://www.proceso.com.mx/410282/liberan-a-jacqueline-y-bryan-ocho-

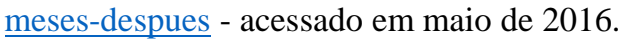


mencionado, não tinham a intenção de derivar na prisão ou desaparição do indivíduo, mas sim em um aviso e escarmento disfarçado de erro inocente. A atitude do Estado representa também a retomada de um conceito de alteridade indesejável previamente usado pelo regime duro do PRI sob Gustavo Díaz Ordáz e Luis Echeverria: a alteridade do estudante de universidade pública politicamente ativo. 


\section{CONSIDERAÇÕES FINAIS}

\section{O futuro em questão}

"Do not go gentle into that good night, Old age should burn and rave at close of day; Rage, rage against the dying of the light. (Dylan Thomas, Do not go gentle into that good night, 1951)

Chegando ao final da presente dissertação é necessário estabelecer um posicionamento político diante do combate às drogas e os seus efeitos colaterais em conjunto com a gravíssima crise do Estado mexicano, das suas instituições e forças de segurança. Chegamos a um ponto no qual não pode se ignorar que o combate às drogas e ao tráfico fracassou. O conflito iniciado há 10 anos pelo ex-presidente Calderón não apenas foi mal concebido e imposto pela hegemonia, senão que perdeu o norte e virou uma política de ação fantoche para encobrir a reorganização do Estado mexicano e do narcotráfico na nova era príista e legitimar o extermínio das alteridades dissidentes.

Em primeiro lugar se faz necessário lançar algumas ideias e conclusões frente ao complexo tema proposto diante da questão das drogas e do combate militarizado às mesmas com a intenção de removê-las da agenda de segurança continental promovida pelos Estados Unidos e quebrar o perverso binômio conceitual do "narcoterrorismo", um pântano abstrato que homogeneíza fenômenos particulares e, muitas vezes, alheios ao tráfico ou ao terrorismo, dentro da ótica da securitização para, de esta forma, legitimar a via armada como solução. Como foi mencionado ao longo da presente dissertação, quando falamos de narcotráfico não estamos nos referindo às drogas, senão à política e ao Estado, as drogas são incidentais, são apenas mercadoria às quais foi adjudicado um status central e demonizado no conflito. As drogas são 
utilizadas como lubrificante para a ação militarizada do Estado contra todo aquilo que esteja relacionado ao indesejável no marco do binarismo primordial inaugurado desde a Conquista: o branco e o não-branco, binarismo que se fragmentaria e diversificaria posteriormente, mas que seguiria de uma u outra forma a lógica binaria dos opostos.

Porém, o uso de drogas não é essencialmente perverso. Outorgar às drogas o lugar que de fato lhes corresponde é o labor essencial na criação de novos paradigmas com respeito ao seu cultivo e consumo para, de esta forma, suspender o seu uso como matéria central do discurso das políticas de segurança continentais e locais. Por sua vez, este labor faz parte do esforço de defesa da diversidade, de modos de vida que escapam dos padrões de "normalidade" do conservadorismo tanto ocidental como oriental e do combate à criminalização dos mesmos.

$\mathrm{O}$ anterior se articula com o contexto mexicano atual: um momento de convulsão social em torno a novas políticas em matéria de direitos civis como é a aprovação do matrimonio homossexual e a autorização de adopção para os mesmos por parte da Suprema Corte de Justicia la Nación - SCJN diante da oposição das igrejas e setores conservadores do país ${ }^{412}$. É ao mesmo tempo um momento de ruptura da deteriorada relação entre a cidadania e as instituições do Estado, encabeçado por Enrique Peña Nieto, diante dos monumentais escândalos de corrupção que surgiram ao redor do mandatário junto com os casos anteriormente descritos de ataques diretos à população civil por parte de agentes do Estado e do narcotráfico em franca cooperação.

O debate sobre as drogas torna-se central de novo diante da situação atual: é imperativo repensar às drogas em matéria de políticas públicas, reconhecer o seu uso atual como artimanha para a legítima intervenção armada do Estado, entender que estão sequestradas oportunisticamente pelo narcotráfico e que este último trabalha extraoficialmente em conjunto com o Estado que oficialmente o combate.

\footnotetext{
${ }^{412}$ Após a iniciativa de Enrique Peña Nieto de legalizar o matrimonio homossexual em todo o país e dias após o massacre de Orlando, a Igreja Católica, representada por Hugo Valdemar, declarou que mobilizaria aos crentes em protestos massivos contra as uniões e adopção de casais homossexuais, além de incitar os fiéis a não votarem nos partidos ou candidatos que apoiem essas uniões, isto em clara violação à Lei de Associações Religiosas e Culto Público que proíbe às igrejas e sacerdotes de participarem, de qualquer forma, na vida política da nação - Y aqui, la Iglesia llama a marchas contra bodas entre homosexuales - Alberto GONZÁLEZ em La Razón, publicado em 13 de junho de 2016, disponível em: http://www.razon.com.mx/spip.php?article311195 - acessado em julho de 2016.
} 


\section{Sobre o fracasso da guerra contra as drogas}

Desde que foi inaugurada por Richard Nixon e reafirmada por Ronald Reagan, a guerra contra as drogas não tem produzido o resultado lógico: eliminar a produção de estupefacientes e diminuir o consumo, assim como a erradicação da violência adjudicada ao narcotráfico, de fato os resultados parecem ser contrários ao esperado. Labrousse (2010) ressalta que a Sessão Extraordinária da Assembleia Geral das Nações Unidas, reunida em 1998 exclusivamente para discutir a questão das drogas, esperava que para 2008, seguindo a militarização do conflito, as culturas de papoula, cocaína e cannabis fossem praticamente eliminadas, coisa que não aconteceu. Por outro lado, a deflagração da guerra no México há 10 anos não trouxe consigo o fim da violência que se afirmava o narcotráfico provocava no país, ao contrário, a fez aumentar descontroladamente.

Porém, o combate armado às drogas não é de fato a única política vigente na matéria, embora seja sim a hegemônica. Parte da retórica da militarização do conflito se centra na afirmação de que a única saída diante do perigo das drogas é a eliminação das mesmas e o confronto direto tanto contra usuários e comercializadores. É claramente uma política criminalizante e altamente corrompível, no entanto, existem sim alternativas que visam em primeiro lugar a não criminalização tanto da droga em si como do usuário, como é o caso da perspectiva da Redução de Danos ${ }^{413}$ que promove políticas de assistência para os usuários a partir de uma perspectiva de saúde pública e políticas de drogas centradas na defesa dos direitos humanos acompanhada de programas de investigação de fortalecimento social ${ }^{414}$. O anterior contrasta radicalmente com a política de militarização impulsionada desde os Estados Unidos na qual os usuários são criminalizados, as drogas são satanizadas e as políticas de drogas se centram no policiamento e na securitização da vida pública sem deixar de mencionar novamente, pelo menos no caso mexicano, as implicações que esta postura tem para a sociedade civil em matéria de direitos humanos fundamentais.

É claro e esperado que as políticas de drogas alternativas, como a redução de danos, tenham que enfrentar a voraz oposição dos Estados Unidos e dos países alinhados com eles, sendo

\footnotetext{
${ }^{413}$ Representada pelo grupo Harm Reduction International - HRI - http://www.ihra.net/

${ }^{414}$ Segundo o estabelecido no Plano Estratégico 2014-2017 de HRI, disponível em: http://www.ihra.net/files/2015/10/05/HRI_StrategicObjectivesPoster_4.pdf - acessado em junho de 2016.
} 
principalmente os chamados países em "vias de desenvolvimento" os quais, segundo Labrousse e o explicitado na presente dissertação, “[...] defendem posições às vezes mais extremas ainda do que as dos Estados Unidos” (2010, p. 135). Esta situação é reconhecida pelo HRI e faz parte do seu planejamento estratégico que se estrutura em função da controvérsia e a oposição que a política de redução de danos gera no cenário mundial, tendo como objetivo principal o fortalecimento do setor de advocacia em prol da redução de danos como uma rede transnacional e a obtenção de reconhecimento por parte da ONU como um componente do direito universal à saúde ${ }^{415}$.

No entanto, a oposição à política de redução de danos e qualquer outra alternativa não é necessariamente dirigida ou orquestrada pela pressão estadunidense para manter um único modelo hegemônico de ação e tampouco emana de motivos moralistas, posturas religiosas ou ideologias políticas. A perversidade da manutenção da política de combate armado às drogas por parte dos Estados Unidos com a cumplicidade dos governos dos países alvo, países nos quais o combate mesmo é realizado e cuja população compõe o grosso das vítimas mortais, é apenas explicada através do modelo explicitado na presente dissertação ao analisar a evolução e o agir do Estado mexicano em relação à população em um contexto de: a) desconexão política entre ambas as partes; b) o funcionamento do narcotráfico como empresa transnacional; c) a colusão de agentes do narcotráfico e agentes do Estado (NarcoEstado); d) uma constante necessidade de legitimação diante da ilegitimidade crônica dos governos; e e) combate histórico às alteridades (dissidentes ou não) principalmente em países subdesenvolvidos ou em vias de desenvolvimento com passado colonial.

Reunindo os pontos anteriores, a guerra contra as drogas nos países periféricos vira um ente perverso, sombrio e desonesto. A guerra contra as drogas não é uma guerra contra as drogas mais do que é mesmo uma ferramenta política de controle social estruturada internacionalmente com a sua origem no centro hegemônico e é um recurso dos governos alinhados como os Estados Unidos para manter o eixo transnacional funcionando, uma porta aberta para a intervenção internacional, um pretexto legitimador e um mecanismo de manutenção do controle ou extermínio seletivo da população de uma nação.

Alain Labrousse (2010) aprofunda na vontade extrema com a que os países periféricos, e outros não tão periféricos, executam a política antidrogas dos Estado Unidos. Ressalta o caso da punição extrema exercida em países do oriente médio, da África ou do sul da Ásia e da adopção 
do combate armado por parte de países latino-americanos. Para o autor, a exacerbação do combate e do ódio gerado em torno ao mundo das drogas não é mais do que uma distração estruturada na legalidade que pretende esconder o lucrativo que o negócio das drogas é para aqueles que o controlam, lembrando que o narcotráfico, como negócio transnacional, se articula com os estados desde as altas esferas até o mais baixo da cadeia de produção como uma mera empresa capitalista: o lucro se concentra no alto com quem comanda os meios de produção.

Portanto, a estratégia é simples: 1) se mantem um discurso oficial de repúdio aos vícios e ao mundo das drogas a partir de posições moralistas, religiosas e de defesa dos bons costumes; 2) se criminaliza aos usuários e são relacionados com vícios históricos como a pobreza, a cor de pele, a origem étnica ou a posição político-ideológica, geralmente determinado por algum resquício de pensamento nacionalista do passado; 3) os pequenos traficantes são feitos alvos da ação da polícia ou do exército (seja como a pena de morte legal ou execuções ilegais); 4) os grandes capos da droga são integrados ao aparelho estatal no alto nível, longe do combate às drogas e perto de onde o grande capital continua fluindo; 5) o Estado se legitima diante da população por combater ao narcotráfico, lucra de acordos internacionais de combate às drogas, mantem o fluxo da mercadoria para o centro hegemônico, protege o fluxo do capital gerado pelo tráfico e a sua integração ao fluxo legal e mantem às portas abertas para a intervenção da potência hegemônica em questão, no caso os Estados Unidos.

De esta maneira é perceptível que a guerra contra as drogas de fato possui duas dimensões: a) o combate oficial contra as drogas e o narcotráfico vistos como ameaças à saúde pública, à paz e aos valores fundamentais da sociedade, o qual serve de fachada para: b) a sua dimensão extraoficial como ferramenta de legitimação dos governos, de defesa ao capital do narcotráfico e de extermínio interno das alteridades dissidentes. Porém, a própria dimensão oficial do combate às drogas emana de uma mentira originaria que determinará decididamente o seu fracasso como forma de erradicação do consumo e tráfico de narcóticos e que, paralelamente, significa seu triunfo e reafirmação na dimensão extraoficial como ferramenta legitimadora, defensora do capital e exterminadora da dissidência já que foi de essa segunda dimensão de onde se originou através das primeiras leis proibicionistas dos Estados Unidos.

O fracasso da guerra contra as drogas como forma de combate e erradicação do consumo e tráfico de estupefacientes encontra-se na sua mentira original: a guerra contra as drogas se inaugurou como uma guerra contra as alteridades raciais dos Estados Unidos na primeira metade do século XX definidas a partir das drogas que cada grupo consumia, posição posteriormente reafirmada e exportada por Richard Nixon e Ronald Reagan, isto é: a guerra 
contra as drogas originalmente foi e sempre será o combate aos usuários pertencentes a certos grupos considerados indesejáveis. É portanto uma política de extermínio social anestesiada e disfarçada através das drogas e o seu consumo como alvo oficial e, portanto, explica por um lado o fracasso da guerra como forma de erradicação do consumo e tráfico de drogas e por outro o seu êxito na conformação de narcoestados, o aumento da riqueza dos cartéis, a legitimação de governos alinhados aos Estado Unidos e a aceitação por parte de grandes setores da sociedade civil do extermínio sistematizado e dirigido de grupos claramente distinguíveis, como são os explicitados na presente dissertação.

De esta forma, uma guerra começada para combater as alteridades nos Estados Unidos representados pelos asiáticos, negros e latinos se justificou através da criminalização do ópio, da cocaína e da maconha. Se estabeleceu a relação entre estas alteridades indesejáveis, seus modos de vida e a sua diferença com o Outro-hegemônico representado pela população branca de ascendência europeia mediante o mal inerente ao consumo de certas substâncias ${ }^{416}$. A falha essencial que derrota a mentira do combate às drogas como a luta contra o vício e a depravação é que o consumo de drogas não se limita a setores sociais ou raciais já que, como foi mencionado, o que torna indesejável a alguém que consome maconha em um local especifico não é a droga per se, senão que é o fato de possuir certos estigmas raciais, sociais e territoriais o que o torna exterminável. Se a luta contra as drogas e a criminalização do consumidor fosse mesmo emanada do combate justo e legitimado pelos bons costumes. A guerra contra às drogas não tem nada a ver com a droga no mesmo sentido em que o narcotráfico não é falar de drogas, senão de política e Estado.

Por outra parte, uma vez estabelecida a falácia originaria que derrota o princípio de "guerra contra as drogas", é necessário considerar outros fatores como a toxicomania e a dimensão econômica que a mercadoria representa como elementos que confirmam o fracasso do combate armado às drogas. Se bem a guerra contra as drogas é na realidade a guerra contra as alteridades indesejáveis, grande parte do problema é que esta estratégia foi aplicada posteriormente como estratégia oficial ao consumo e aos problemas dele derivados, ou seja, alguém acreditou na mentira. Por sua vez, a negativa de abrir a porta para outras alternativas que não se fundamentem na militarização do conflito se explica através dessa falácia originaria, já que

\footnotetext{
${ }^{416}$ Para maior informação sobre este tema, Mike WALLACE e Carmen BOULLOSA publicaram a obra titulada A Narco History: How the United States and Mexico jointly created the "Mexican Drug War" (2015) que aprofunda na questão do combate às alteridades indesejáveis utilizando o bode expiatório das drogas e a posterior expansão do conflito para o México.
} 
reconhecer o fracasso do combate armado seria ao mesmo tempo reconhecer os motivos extraoficiais que fazem que a guerra ainda seja mantida em diversos países.

Adalberto Santana (2012) analisa o consumo de drogas e a toxicomania como eixos articuladores de uma estrutura cíclica perversa do sistema político-econômico mundial e que evidencia a falácia da guerra contra as drogas como política de erradicação do consumo teimosamente aplicada, embora já tenha sido dito que a sua essência a derrota de origem. Em primeiro lugar o autor desconstrói a dimensão da toxicomania na sociedade contemporânea que vai mais além de um formato de alienação tradicional, tal como a ideologia ou a televisão, já que, aponta, embora esses exemplos sejam alienantes per se, não mantêm ao indivíduo drogado quimicamente e, portanto, continua em maior ou menor medida socialmente ativo. Em paralelo menciona que de fato a acumulação de drogas em uma sociedade não é malicioso essencialmente, senão que a perversidade aparece ao unir dialeticamente a toxicomania com alienação criando um estado de ataraxia que vira essencialmente uma forma de vida e uma necessidade tanto do indivíduo como da política social dominante. O indivíduo em situação de ataraxia não é mais ativo socialmente. Portanto, o autor coloca, a toxicomania é uma ferramenta da política social dominante como forma de contenção social e " [...] en materia de represión, pero por primera vez en la historia, la química sustituye a las cadenas, las cuerdas y las cárceles". (SANTANA: 2012, p. 234).

E é claro, as drogas são produtos que se vendem por si mesmos como coloca o autor, é mercadoria que não precisa de publicidade e consegue atingir patamares de desejo que qualquer outro produto queria ter, situação que é válida também para as chamadas -drogas legais- como o tabaco, café ou álcool. É apenas necessário ver um tempo considerável de televisão para notar a ausência total de propaganda de cigarros (que antigamente vendiam mais um status de masculinidade ou social do que o tabaco mesmo, como eram as propagandas do caubói da Marlboro), ou os anúncios de cerveja que são mais produto de uma concorrência entre marcas apelando a outros elementos mais do que à cerveja mesmo (por exemplo, Heineken se oferece como a cerveja para assistir futebol europeu e Budweiser como a cerveja da vida noturna).

De esta forma vemos que a demanda das drogas e o seu consumo, além de ser antigo e comum, é praticamente impossível de erradicar dada a fascinação que geram através de uma "[...] evasión psíquica de la realidad por medios químicos" (SANTANA: 2012, p. 234) que, segundo o autor, acontece em determinados setores sociais. Mas é aqui onde cabe uma discordância com o autor já que a direção que Santana (2012) toma é para as classes sociais baixas e as formas de 
alienação e ataraxia para com um mundo estruturado de forma hostil em torno deles ${ }^{417}$. No entanto, se bem os motivos que levam ao consumo de drogas entre um morador de favela e um freguês de boate podem ser um tanto distintos, a finalidade continua sendo a mesma: evadir a realidade (percebida como hostil, sem graça, etc.) de forma imediata. A questão da ataraxia pode ser mal-entendida como um estado de zumbificação, mas esse estado de imperturbabilidade não é sinônimo de letargia senão de alteração sensorial e modificação da percepção da realidade que pode ir desde a euforia descontrolada que o jovem da boate sente até a tranquilidade que o cheirador de cola na rua percebe ao sossegar a fome. Aliás, resulta curioso que este último seja o percebido como indesejável enquanto o primeiro seja percebido como o maneiro.

E é precisamente essa última colocação que nos leva ao fracasso da guerra contra as drogas como mecanismo de combate ao consumo das mesmas. Já foi estabelecido que o consumo de drogas não é novidade na sociedade humana, porém, na sociedade contemporânea adquire uma nova dimensão ao virar ferramenta da política do Estado em matéria de contenção social. Em este sentido, o contexto político-econômico tem um papel central dada a configuração das sociedades de economia capitalista e da própria lógica do livre mercado em paralelo com as condições de vida, a diminuição da mobilização social e o consumismo descontrolado que o sistema econômico dominante traz consigo. Estes fatores, segundo Santana (2012), propiciam as condições para o consumo de drogas, seja como forma de tolerar as condições adversas ou da continuação de uma cultura hedonista predominante em outros setores sociais.

A circulação da mercadoria se aproveita então das condições geradas pelo sistema econômico hegemônico que favorecem a sua demanda e pela sua própria estrutura que favorece a sua circulação global já que, lembremos, o narcotráfico é essencialmente uma empresa neoliberal transnacional que movimenta capital dentro do fluxo econômico mundial e, por tanto, é peça funcional do sistema. Como todo produto comercializado, a droga é direcionada para distintos perfis de consumidores que determinarão uma inter-relação de elementos como a qualidade da droga, o tipo, o nome do produto, os efeitos, a quantidade e o preço (SANTANA: 2012). O anterior é o motivo pelo qual o jovem mencionado não cheira cola na boate e o morador de favela não consome êxtase na rua. Do anterior decorre uma conclusão lapidaria já que é possível observarmos que as condições que o próprio sistema capitalista na sua fase neoliberal produz são aquelas das quais o narcotráfico lucra para distribuir distintos tipos de droga de valor

\footnotetext{
${ }^{417}$ Sigmund Freud aprofunda no tema na obra "O mal-estar na cultura".
} 
variável para todos os setores sociais com o fim de "[...] evadir un malestar condicionado social, económica o políticamente" (SANTANA: 2012, p. 236). Isto é, o consumo de drogas pré-data tanto ao modelo econômico atual como o tráfico das mesmas e, portanto, o narcotráfico é decididamente uma peça essencial da economia neoliberal tanto no campo do fluxo de capital transnacional como uma ferramenta política de controle social da população através de duas formas: 1) a alienação química e 2) o uso político do seu combate.

Mediante a criação de estigmas de pobreza e delinquência (ou demais vícios atribuíveis às parcelas pobres da população) em torno da epidemia do consumo de drogas, o próprio Estado neoliberal se legitima através de discursos moralistas ou que ressaltam uma ética social conservadora para combater ao consumidor e ao pequeno traficante sem perturbar nas suas funções ao grande aparelho do tráfico internacional que faz parte da própria economia mundial. Além do mais e como aponta Santana (2012), o discurso moralista de proibição funciona mais como marketing que motiva a experimentar com o proibido (como foi mencionado na presente dissertação com as pouco efetivas campanhas antidrogas da televisão).

O analise anterior evidencia um círculo perverso de auto alimentação da economia mundial na sua fase neoliberal em torno ao consumo de drogas que a pré-data. $\mathrm{O}$ consumo de drogas se praticou, se pratica e se praticará com distintos fins, porém: 1) o atual sistema políticoeconômico não apenas favorece o acesso às drogas com ajuda dos canais internacionais de circulação da mercadoria, senão que gera as condições de qualidade de vida necessárias para que certas parcelas da população apelem à toxicomania como forma de evasão de uma realidade que pode ser desde hostil até chata; 2) por sua vez, uma população afetiva para a toxicomania permanece em um estado de ataraxia que diminui a sua participação e interesse na vida social e política e os escraviza ao narcotráfico ao ser este o único médio para conseguir o produto desejado; 3) em paralelo, o narcotráfico monopoliza o tráfico da mercadoria com a anuência da proibição do Estado que gera um monopólio transnacional que extraoficialmente faz o capital circular e integrar-se no fluxo nacional e mundial; 4) e finalmente, essa proibição é produzida a partir de um discurso moralista e pseudo-ético do Estado para não apenas proibir a distribuição legal da droga, senão para combater aos consumidores de certos setores sociais, securitizar a vida pública e legitimar a intervenção generalizada das forças de segurança desde que o assunto esteja minimamente relacionado com drogas e, de esta forma, assegurar a sobrevivência do Estado neoliberal mediante o extermínio legitimado das alteridades dissidentes.

Eis a falácia da guerra contra as drogas como política de combate ao consumo e tráfico das mesmas e o seu verdadeiro rosto como parte essencial do sistema neoliberal. 
De novas políticas sobre as drogas e os obstáculos no caminho.

Toda nova política ou alternativa, todo pensamento em torno das drogas e de qualquer mudança paradigmática em qualquer aspecto da vida política e cidadã tem que se fundar em uma premissa e na jurisprudência histórica decorrente dela: A guerra contra as drogas fracassou.

O principal obstáculo para toda reforma e tentativa de acabar com a guerra contra as drogas é o seu status como "regime oficial" legitimado pela ONU e orquestrado pela Comissão de Narcóticos - CND e a Junta Internacional de Fiscalização de Estupefacientes - JIFE. Isto dificulta o questionamento da estratégia e a negociação política para reformar sequer a concepção de como se deve enfrentar a questão das drogas e do narcotráfico (BARRA: 2015). Trata-se de um legado fossilizado e enquistado nas estruturas de pensamento mundial desde a década de 1960 e que continua nos governando com os paradigmas, os medos e a ignorância dessa época. Eliminar esse "regime oficial" não apenas é um passo necessário no combate ao narcotráfico, senão uma necessidade impostergável.

É também o primeiro passo estratégico para a desarticulação, ou pelo menos, o enfraquecimento da estrutura do narcotráfico. Adam Barra (2015) enumera o que ele chama de "consequências não intencionais" do regime oficial das drogas (a questão do "não intencional" é, no entanto, discutível): a) criação do mercado ilegal e criminal de grande lucro; b) relegação das políticas de saúde a um nível inferior; c) deslocamento geográfico dos centros de produção e distribuição de droga (i.e., da Colômbia para o México); d) uso de sustâncias "alternativas" para a elaboração de droga por causa da proibição de outras; e) criminalização e estigmatização do consumidor. Portanto, o custo-benefício da manutenção da guerra contra as drogas é deplorável apenas observando as consequências "não intencionais" geradas em matéria de segurança e desenvolvimento deteriorados, saúde pública ignorada, direitos humanos violentados, discriminação rampante, delinquência em aumento e economia fragmentada em um limbo entre o legal e o ilegal (BARRA: 2015).

O combate armado contra as drogas é o vício mais perigoso que ainda nos sobrevive e acabar com ele significaria começar a desestabilizar o círculo perverso de funcionamento do narcotráfico e dar o primeiro passo para confrontar a crise dos Estados contemporâneos. Um primeiro passo proposto é eliminar todo resquício de menção oficial de "luta", "combate" ou "guerra" do discurso institucional, estatal e civil e esvaziar esses termos da essência estoica, moralista e legitimadora que se pretende outorgá-lhes desde a demagogia de Estados enfraquecidos em busca de legitimação dos seus líderes, como o caso de Felipe Calderón. 
O uso indiscriminado de termos bélicos como instrumento de campanha política foi causa direta da militarização do narcotráfico e da derrota calderonista que trouxe a explosão da violência em todo o país. Norberto Emmerich (2015) exorta urgentemente a dar um primeiro passo na mudança do discurso institucional para mudar a perspectiva satanizada que se tem das drogas para conseguir a sua desvinculação do narcotráfico e não aludir a este último de forma ameaçadora e confrontadora. Trata-se de um discurso que deve se focar nas drogas não como mercadoria do narcotráfico nem como a origem de todos os vícios, senão como uma realidade que existiu e existirá na sociedade e cuja vinculação com o narcotráfico e a violência não é provocada pela sua existência nem pelo seu consumo, senão que foi o narcotráfico quem sequestrou violentamente o consumo e a distribuição das mesmas.

O narcotráfico, por outra parte, é territorial e depende do uso de territórios para traficar, plantar e vender a mercadoria e, como aponta Emmerich (2015), isto acontece em territórios na escala municipal se aproveitando dos vazios na estrutura estatal que a mesma guerra contra as drogas provocou. Portanto, povoados inteiros abandonados pela nula administração política são ocupados por traficantes que encontram literais espaços vazios para agir como foi explicado no caso de San Fernando, cidade na qual a ocupação do território por parte dos cidadãos está limitada até a pôr do sol. De uma ou outra forma, esta dinâmica se naturaliza e os cidadãos a entenderão como uma normalidade até institucional quando as forças de segurança e a administração da cidade encontram-se ao serviço do narcotráfico. Em paralelo, a política militarizada e a estratégia de unificar às policias municipais e estatais em um mando único sob o controle do governador do Estado, ignora totalmente a composição celular do território e elimina ao município como espaço de ação da "estratégia" da federação na guerra. Portanto, enquanto o narcotráfico funciona mediante a conquista paulatina de pequenos territórios que juntos formam uma rede inter-relacionada, a federação desestima o poder conjunto dos municípios e pretende estabelecer uma lógica de uso de espaço federal em territórios municipais.

Uma política de uso de espaço deve ser congruente com o território em questão e, além do mais, deve entender as suas particularidades geográficas e populacionais para reestabelecer a ocupação e uso do mesmo por parte dos cidadãos. Para o anterior, uma visão desde a escala federal é inadequada pela própria lógica de funcionamento de uma federação que é composta essencialmente pelos municípios. Emmerich afirma que é labor imperativa outorgar qualidade e garantias de vida e uso do espaço para os cidadãos e estimular a convivência das pessoas com garantia de segurança sem importar o horário ou momento do dia. Isto se traduz em transporte 
público de qualidade, serviços públicos como parques, praças e eventos públicos em conjunto com a regularização, pavimentação e instalação de serviços básicos como luz e agua para as zonas mais marginalizadas (EMMERICH: 2015). De esta forma, o espaço começa a ser usado pela população e pelo Estado federal através da delegação da responsabilidade para um governo municipal forte no qual o consumo e a circulação de droga viram uma escolha individual e não uma imposição já que, em um espaço dominado pela cidadania e, por consequência pelo Estado, o narcotráfico não estabelece relações de poder nem de dominação (EMMERICH: 2015).

Ao mesmo tempo, o reconhecimento da importância do município contraposto à desconsideração do governo federal deve acontecer em matéria de prevenção, informação e tratamento do consumo de drogas desde uma perspectiva de saúde pública e não de segurança. Trata-se da descentralização da estratégia e a delegação de responsabilidades para os municípios previamente fortalecidos pela federação. De esta forma aumenta a possibilidade de obter resultados positivos a partir da criação de políticas de uso do espaço, de educação e da prevenção e tratamento do consumo de drogas a partir da realidade e das necessidades de cada município (VERGARA: 2015) e assim evitar o rolo compressor homogeneizador da federação. Porém, não deve ser confundido com o abandono federal do município que derivaria no surgimento de caciquismos locais e a volta do narcopoder pela via do monopólio da violência, o qual resultaria em uma intervenção direta da federação como aconteceu no caso das autodefesas, o conflito com o Exército em Michoacán e com os 43 estudantes de Ayotzinapa em Iguala (VERGARA: 2015).

A valorização da participação cidadã focalizada nas necessidades particulares de cada território em conjunto com instituições fortes e realmente representativas da cidadania e que, de fato, tenham capacidade de ação, são fatores fundamentais para ter um município forte e que ao mesmo tempo não esteja desligado do Estado federal. Ou seja, a criação de uma rede de participação institucional, estatal e cidadã que funcione, ironicamente, seguindo a lógica de um cartel da droga, ou como o explica Eduardo Vergara: “[...] externalizando las actividades que no logran hacer de forma eficiente, adaptando las estrategias de acuerdo con los universos particulares y atomizando el trabajo para que cuente con dinamismo y adaptabilidad" (2015, p. 126) priorizando a capacitação continua e educação dos cidadãos.

Evidentemente a política impulsionada desde os Estados Unidos é aquela de reprimir a oferta e criminalizar o uso de drogas. Isto é uma política direcionada totalmente contra a cidadania sem sequer pensar em atingir às próprias estruturas do Estado que favorecem a infiltração e o agir do narcotráfico. Os motivos para a existência e manutenção de essa dinâmica já foram 
explicitados, porém, desde o ponto de vista estratégico para eliminar ao narcotráfico, esse modo de ação é ineficaz. A demanda sempre vai existir, mais ainda se considerarmos que as condições para a existência da demanda são provocadas pelo próprio sistema político-econômico e, se há demanda, haverá oferta. Isto é uma lógica inescapável e pretender reprimir violentamente a oferta e reduzir a demanda mediante campanhas na TV e o uso punitivo e letal da força contra o consumidor vai apenas gerar um espiral de violência e conflito perpétuo. Portanto, tem que se aceitar a existência da demanda e pensar a partir de essa realidade. A questão de acabar com a demanda é impossível, mas não é impossível reduzir a demanda de drogas para o mercado ilegal que monopoliza a distribuição por graça da proibição estatal. Além do mais, a proibição faz que, pela dificuldade logística de produção e comercialização ilegal, o preço da mercadoria seja elevado. Isto não impede ao consumidor de comprar, mas sim faz que o fluxo de capital para o narcotráfico seja gigantesco o suficiente como para virar uma empresa transnacional de interesse para o Estado e o aparelho econômico mundial e, de esta forma, criar o círculo perverso já explicitado (SANTANA: 2012).

É aqui onde nos encontramos com um dilema maiúsculo: a legalização. Na teoria, a legalização da droga destruiria economicamente ao mercado ilegal, o produto seria de melhor qualidade e a violência ligada ao tráfico desapareceria. Poderia se pensar que ao legalizar as drogas, o consumo ou o interesse pelo consumo, diminuiria ao eliminar o tabu do "proibido". Porém, temos de considerar alguns fatores: 1) o Estado já lucra com a existência do mercado ilegal e o “combate" oficial não apenas serve de legitimação senão também como ferramenta de controle social, portanto: qual seria o interesse do Estado para legalizar e administrar diretamente a comercialização?; 2) grande parte do consumo acontece em países onde o livre mercado é deus na Terra e o setor privado ia querer parte do botim; 3) seria um pesadelo logístico para os Estados de população considerável (i.e., Estados Unidos, México, Brasil) e as implicações para o gasto público não podem ser ignoradas; 4) a existência do NarcoEstado: o rompimento entre Estado e narcotráfico não ia ser menos do que uma traição e teria um custo político gigantesco para quem tiver a ousadia, isto sem falar da violência resultante; 5) a legalização teria que ser impulsionada desde a periferia mundial; as nações que sofrem a guerra contra as drogas teriam que ser as primeiras a considerar esta via, a qual, implicaria uma confrontação direta com as políticas estadunidenses; e 6) seria romper com um paradigma que permanece há mais de um século em países nos quais as instituições conservadoras têm peso específico na política interna e no pensamento de um povo escassamente educado e informado. 
Em matéria de elaboração de políticas públicas e exclusivamente sob a hipótese de termos um Estado do qual o narcotráfico foi expurgado e que existe um consenso de bloque regional latinoamericano para se contrapor às possíveis pressões estadunidenses, podemos começar a pensar o caminho da legalização. As implicações para o futuro em questão das particularidades políticas e culturais do atual contexto mexicano serão discutidas no próximo apartado.

A via da legalização deve ser considerada, nas palavras de Barra (2015) mais como um processo do que uma política pública aplicada frivolamente. Isto é, não apenas deve se considerar um balanço entre o papel do Estado e do livre mercado, senão que cada política de legalização deve se focar para as particularidades da sustância em questão e não somente jogar para o ar decretos de legalização. $\mathrm{O}$ autor apresenta cinco modelos para pensar um esboço do processo de legalização ${ }^{418}$ : a) distribuição com receita medica para uso medicinal e espaços de consumo controlado (perspectiva medicinal); b) venda em farmácias (para uso medicinal); c) pontos de venda autorizados (para uso recreativo); d) estabelecimentos com licença para a venda e consumo; e) venda por provedores não autorizados em alguns casos únicos.

Estes cinco modelos estabelecem controle sobre a sustância de maior a menor grau, porém, o problema essencial é a utilização de um só para todas as drogas, como se pretende fazer com a legalização "medicinal” da maconha ${ }^{419}$. A aplicação do modelo A não é compatível com o uso recreativo da maconha, seria o equivalente de precisar de ir no hospital para pegar uma receita médica e depois ir na farmácia para comprar uma cerveja. Isto funciona como uma forma de demonstrar que a legalização é inútil e ineficiente e mais ainda, cansativa para o consumidor que apelaria à via da compra ilegal por via do narcotráfico, muito mais rápido e eficiente.

Continuando, o modelo A é aplicável para a terapia de redução de danos para drogas mais fortes, assim como o modelo D seria suicida para a venda e consumo de, digamos, heroína. Portanto, os modelos existem, mas ainda resta a problemática da sua aplicação propositalmente generalizada e pobremente concebida que continua funcionando como ferramenta para demonstrar a ineficácia da legalização por parte dos defensores da luta armada já que abrem a

\footnotetext{
${ }^{418}$ Grifos nossos

${ }^{419}$ A iniciativa presidencial de Peña Nieto em abril de 2016 contempla o aumento do porte legal para 28 gramas (consumo individual) assim como o uso da planta para fins científicos e medicinais. Porém, a questão da distribuição e da obtenção dessas 28 gramas ainda depende do dealer. Esta "legalização" superficial pode ser interpretado como uma dificuldade ou preguica para pensar com seriedade uma verdadeira reforma no "regime oficial" das drogas, porém, é parte da estratégia de oferecer uma legalização mal feita e ineficiente para reivindicar o combate às drogas como a única via que produz resultados - Propone Peña elevar dosis de mariguana y permitir su uso medicinal - Redacción Proceso, publicado em 21 de abril de 2016, disponível em: http://www.proceso.com.mx/437964/propone-pena-ampliar-posesion-mariguana-uso-medicinal - acessado em junho de 2016.
} 
porta para a legalização, mas a banalizam e oferecem resultados fracos com a intenção de deslegitimar esta via.

No entanto, esses modelos existem e se aplicam na vida cotidiana com as chamadas -drogas legais- e são perfeitamente viáveis. O modelo A serve para medicamentos controlados como antibióticos; o B para álcool e tabaco; o C é o aplicado aos bares e lugares públicos como eventos musicais ou estádios de futebol e o D para sustâncias como o café, o chá mate e medicamentos que não precisam de receita médica (BARRA: 2015). Portanto, os modelos de legalização devem ser pensados como um processo de categorização de drogas e a forma em que serão distribuídas dependendo do uso (medicinal ou recreativo) e dos efeitos da mesma. A generalização e o pensamento superficial são ferramentas políticas para deslegitimar esta via por parte dos que lucram com o combate armado, isto é, os próprios grandes capos da droga agora grandes senhores do capital transnacional, os governos ilegítimos, os agentes do NarcoEstado e as agendas de contenção e extermínio da população.

Além do mais, há uma série de obstáculos e vícios insidiosos que dificultam a ruptura paradigmática e a desmitificação das drogas, vícios tais como a corrupção sistémica, passado colonial e pensamento neocolonial, desigualdade econômica e cultural generalizada, caciquismos e um sistema neoliberal depredador, a presença insidiosa da religião institucionalizada na vida política e cidadã, democracia esvaziada de significado, instituições desligadas dos interesses da população, Estado de direito enfraquecido, e outros vícios como a homofobia, o racismo e retórica de ódio no geral.

Contudo, nos últimos anos é possível observar o enfraquecimento dos medos e dos preconceitos do passado através da legalização da posse de certa quantia de droga para consumo pessoal, a própria existência de programas alternativos como a noção de "redução de danos", o respeito ao uso tradicional e ritual de certas sustâncias como a coca na Bolívia ou o peyote no México, assim como o crescente debate sobre o uso medicinal da maconha (Barra, 2015). Este último debate ainda encontra-se matizado por medo e preconceito em torno ao uso recreativo da maconha já que, embora as fibras da planta e as sustâncias químicas tenham mesmo outro uso além do recreativo, existe todavia o receio de reconhecer o uso recreativo da maconha como um dos seus usos que mais interesse gera e que foi aquele que movimentou e movimenta a maconha no mercado mundial. 
As questões anteriormente apresentadas em matéria de novas políticas sobre as drogas e os obstáculos em questão, se particularizam ao falar do contexto mexicano atual (2016). A continuação o estado do regime hoje e o futuro em questão.

\section{Sobre o futuro da nação}

O futuro em questão não depende apenas da mudança paradigmática em torno do consumo e circulação de drogas consideradas ilegais e do negócio transnacional que as monopoliza. A situação atual do país e do regime que o controla é gravíssima pela vulnerabilidade da população diante de um governo historicamente autoritário, porém enfraquecido e em constante agir para recuperar a sua antiga força mediante a mobilização das forças de segurança e a paulatina militarização do país.

A guerra contra as drogas de Calderón deixou a porta aberta para o retorno autoritário do rolo compressor priísta que se aproveitou do conflito e das estruturas de securitização e militarização da vida pública deixadas pela administração anterior. De esta maneira obteve a via perfeita para impor as suas condições e reformas estruturais mediante a manobra e negociação política impregnada de atos de corrupção com os partidos de suposta oposição, por um lado, e por outro, mediante o uso da força previamente legitimada no marco da guerra contra as drogas contra as alteridades dissidentes do projeto oficial.

É por isso que começar a pensar um novo rumo para a nação deve ser feito a partir do cenário atual aceitando a gravidade do mesmo, a dificuldade extrema que este labor represente e os perigos que implica para a nossa própria segurança e vida. Falar de presos políticos, de desaparições forçadas e execuções clandestinas de opositores ao regime do PRI, contrário à concepção comum da classe média padrão ao tentar diminuir a nossa geração e enaltecer a sua, como comumente acontece, não é uma coisa do passado autoritário da nação da qual apenas essa geração anterior sofreu nem é fala de "maconheiro vagabundo", senão que é uma prática comum do regime atual direcionada contra a nossa geração de uma maneira mais perversa, intensa, sistematizada e cruel do que aconteceu com aquelas gerações dos nossos pais na década de 60 e 70. 
Portanto, para pensar o estado do regime atual e o futuro em questão é preciso considerar os seguintes fatores como os vícios mais perigosos que prevalecem hoje; a) a corrupção desbordada e a ostentação criminal dos grandes empresários e da oligarquia no geral em conjunto com a desconexão social e humana que essa acumulação gera criando, de facto, duas formas de experimentar a realidade e duas classes de cidadão e o agir diferenciado do Estado para cada uma, o qual reforçará a existência e categorização de alteridades desejáveis e indesejáveis; b) a fantasia pequeno-burguesa da classe média de acreditar que se encontra mais próxima das oligarquias do que das classes baixas e a sua reprodução do binarismo do desejável e do indesejável fazendo a função de buffer zone, de escudo humano e de legitimador cumplice em favor da hegemonia e em detrimento deles mesmos; c) produto da legitimidade outorgada e das liberdades sacrificadas em prol da segurança pela classe média, o Estado legaliza o Estado de exceção pela via institucional da suposta representação cidadã e avança na militarização da Federação; d) os ataques às alteridades dissidentes se multiplicam mediante "ações legitimas" do Estado que são defendidas por grande parte da população mediante o uso de posturas racistas e classistas fundadas em estigmas do "indesejável"; o qual: e) normaliza o discurso de ódio que ameaça os direitos de minorias consideradas indesejáveis como produto da tradição conservadora interiorizada e reproduzida pelas classes medias e baixas e que é impunemente reforçado por instituições paraestatais como a Igreja Católica e pela grande mídia com total impunidade.

\section{O regime hoje}

Para entender o estado atual do país e explicar a série de fenômenos provocados pela deflagração da guerra contra as drogas, seria necessário voltar às considerações iniciais em torno ao pensamento de Pierre BOURDIEU da produção do desejável e do indesejável partindo do binarismo primordial do primeiro contato com os europeus. Esta estrutura pré-existente e as definições posteriores feitas pelo indivíduo influenciadas -mas não determinadas- por ela, ou seja, o habitus mexicano -levando o conceito de Bourdieu (2002) à escala tradicional do nacional- possui uma estrutura subjacente do que é bom e ruim, desejável ou indesejável, charmoso ou o horrendo, etc. Essa classificação primaria dos opostos tem inegavelmente uma origem racial que ainda permanece presente embora não seja da mesma forma pura da época da conquista. 
Se bem é certo, a existência de um habitus não pode ser considerada uma regra determinante pela própria relatividade da natureza dos conceitos e pelo ponto de vista do observador. Porém o centro de essa relatividade encontra-se ancorada no binarismo primordial no qual várias civilizações foram submetidas e depois reduzidas a uma só (categoria -índio-) por outra que depois sacralizou essa submissão com a criação da repetição ritualística da tradição e do dogma nacionalista. Por tanto, toda relatividade estará sempre sujeita à percepção original do desejável e do indesejável, mesmo quando em algumas circunstâncias e contextos particulares o indesejável seja tido como desejável e vice-versa.

Essa liquidez e facilidade de transmutação que o conceito adquire mediante a apropriação e reinterpretação de "estigmas sociais" que certas parcelas da população fazem é o que dificulta entender, e por momentos parece desmentir, a linha central do habitus mexicano que define incontestavelmente o que é aceito e o que é rejeitado a partir de um eixo primordialmente racial que foi se fragmentando com o decorrer da história. O pensamento nacionalista do PRI se aproveitou de essa confusão para criar todo um monumento de adoração falaz em torno do mestiço e do índio pré-hispânico e conciliar o aparente paradoxo de que a classe historicamente dominante se mantivesse no poder. Além do mais, esta estratégia foi facilitada pela face integracionista do partido. A mesma confusão permitiu, por um lado aos estadunidenses, e por outro ao Estado mexicano, começar a guerra contra 1) as drogas, que são parte da história humana e em particular daqueles que podem pagar por elas e têm a capacidade e liquidez econômica de viver um estilo de vida hedonista no qual a toxicomania e a alteração sensorial são luxos que podem adquirir; e 2) contra o negócio quintessencialmente neoliberal: o narcotráfico - isto na sua base contra os pequenos traficantes, lembrando que os grandes capos são relativamente intocáveis - .

Essa confusão faz que, embora a guerra contra as drogas esteja fundada em uma falácia originaria que derrote seu propósito oficial, continue se desenvolvendo com a anuência da população, mesmo daquela que se encontra em perigo de virar alvo e que se assume como desejável. A classe média é maioritariamente mestiça e o nacionalismo priísta foi fabricado e dirigido para apelar a essa classe, para fazê-la sentir o foco de atenção do Estado enquanto outros, os que sempre dominaram, continuavam dominando e dirigindo os destinos da nação com a anuência dessa classe média que se assume mais próxima da elite do que da classe baixa indesejável, a qual, é definida de essa forma por diversos motivos e estigmas sociais, raciais, políticos, sexuais, etc. 
Isto não é mais do que a interiorização da dominação daqueles que definiram e continuam classificando às alteridades entre desejáveis e indesejáveis e, portanto, o que não faça parte desse mundo é indesejável. Enquanto isso, fazer a classe média se conceber como elite possibilita legitimar absolutamente tudo o que seja feito em prol da defesa de lugares comuns como a família "tradicional”, a segurança, a pátria e os bons costumes.

Bem afirma Bourdieu ao escrever que mediante a interiorização da dominação emanada de um habitus primordial estabelecido por uma hegemonia, é possível fazer que a ordem estabelecida e as relações de dominação que produzem atropelamentos de direitos contra muitos e a manutenção de privilégios para poucos seja perpetuada com tanta facilidade, fazendo que injustiças e incidentes históricos sejam deixados de lado e que as condições miseráveis de vida, próprias ou alheias, sejam aceitas e consideradas naturais (BOURDIEU: 2000, p. 4).

É assim que para grandes setores da classe média seja fácil esquecer do Massacre de Tlatelolco contra estudantes de classe baixa e média, ou do Massacre de Acteal contra índios, os 43 de Ayotzinapa que eram estudantes indígenas e militantes políticos. Todos reúnem estigmas indesejáveis: estudantes, pobres, índios, de esquerda e militantes que merecem morrer, é apenas lógico e aceitável. Em conjunto com Tlatlaya e San Fernando, estes são os casos emblemáticos pela difusão mediática e pela magnitude que tiveram. $\mathrm{O}$ fato de serem apenas alguns quantos casos os noticiados exibe a facilidade com a que se ignora e se naturaliza a violência cotidiana e constante que a guerra trouxe consigo. Isto é uma retórica de negação vinda desde o titular do Executivo $^{420}$ - seja Calderón ou Peña Nieto - que minimiza, criminaliza e justifica às mortes das alteridades desde que sejam indesejáveis ou periféricas. Assim a classe média se sente segura ao ver um padrão de extermínio que se ajusta a estigmas indesejáveis e, portanto, os reafirma como tal, os reproduz, os legitima e os atribuirá às próximas vítimas para justificar essas mortes e reafirmar-se como a protegida do Estado. Isto normaliza crimes contra a humanidade e alimenta a cultura da impunidade que bebe diretamente da fonte da corrupção e da criminalização.

Se explica assim a volta do PRI ao poder em 2012 apesar da história autoritária do partido e o iminente retorno do PAN em 2018 apesar de ter sido Calderón quem deflagrou o conflito que

\footnotetext{
${ }^{420}$ Se identifica uma "retórica" da negação tanto na administração de Calderón e de Peña Nieto pela minimização dos homicídios ou massacres e a teimosia de chamá-los de "casos isolados", assim como os ataques aos relatórios de funcionários da ONU, do GIEI e de ONGs de direitos humanos - Atrocidades aceptadas - Denise DRESSER em Proceso, publicado em 18 de junho de 2016, disponível em: http://www.proceso.com.mx/444420/atrocidadesaceptadas - acessado em junho de 2016.
} 
até hoje está destruindo à nação e o tecido social, criando condições de vida miseráveis e, finalmente, explica também a enorme dificuldade de um partido de esquerda chegar ao poder.

Do anterior decorre a legitimação por parte da sociedade mexicana da intervenção intempestiva das forças de segurança na esfera pública e da crescente militarização e paramilitarização que se soma à onda mundial de ressurgimento do pensamento e práxis de corte fascista. Em prol da segurança pela ameaça representada por um inimigo sumamente abstrato - seja o comunismo no Brasil, o islã radical e os imigrantes nos Estados Unidos, os refugiados na União Europeia ou as drogas e o narcotráfico no México - a população civil entrega liberdades e demanda um Estado forte em matéria de ostentação das armas contra o inimigo abstrato seja interno ou externo. Portanto, o Brasil, país no qual setores da sociedade exigem o regresso da ditadura militar, nos Estados Unidos se fala de muros fronteiriços gigantes e guerra contra o islã, os europeus reinterpretam o pesadelo dos campos de concentração desta vez para refugiados e os mexicanos permitem a presença constante do Exército e da Polícia Federal na esfera pública para exercer labores de policiamento e de contenção civil, até agora de maneira extraoficial e extralegal.

A nação mexicana vive um intenso processo de militarização e paramilitarização com a anuência da população civil que está disposta a entregar liberdades em troca da aparente segurança armamentista. Até a metade da presidência de Enrique Peña Nieto, o modelo aplicado era o da "guerra civil não declarada" explicada na pressente dissertação através da teoria de Giorgio Agamben (2005) sobre o Estado de exceção de facto e a própria falácia e paradoxo da aplicação do mesmo por ser uma suspensão legal do Estado de direito. Isto é suspender a lei mediante a lei, ou dividir entre zero.

Se bem, Agamben (2005) considera este vácuo como um paradigma dos governos contemporâneos pela facilidade primária de agir fora da lei com a benção da lei mesma. Porém, o que acontece quando o Estado tenta legislar e trazer este paradigma à cotidianidade fazendo que o Estado de exceção vire a normalidade legal e não seja mais uma condição de suspensão de garantias individuais e da ordem jurídica em situações de extrema necessidade, senão que a suspensão dos direitos civis seja uma questão corriqueira e cotidiana?

Enrique Peña Nieto é lembrado pelo ato de repressão perpetrado em 2006 em San Salvador Atenco quando era governador do Estado de México. Trata-se de um operativo que durou mais de 10 horas e utilizou 3 mil elementos da Polícia Federal, Estatal e Municipal para reestabelecer a ordem pública após uma série de protestos contra a construção do novo Aeroporto 
Internacional da Cidade do México em terrenos propriedade dos camponeses locais. Os policiais invadiram 20 casas e o saldo do operativo foram mais de 100 civis detidos, 50 feridos e dois mortos, em conjunto se reportou o abuso sexual de 23 mulheres ${ }^{421}$. O então governador defendeu o uso legítimo da força do Estado para restabelecer a ordem pública.

Após 10 anos e agora como Presidente da República, o mandatário impulsa a aprovação da Lei Reguladora do artigo $29^{\circ}$ constitucional $^{422}$ que estabelece os preceitos legais para a suspensão de garantias individuais no território nacional em casos de - invasão, perturbação grave da paz pública ou de qualquer outro que que ponha à sociedade em grave perigo ou conflito -, atribuição que cabe apenas ao Presidente da República com autorização do Congresso da União. $\mathrm{O}$ artigo continua dizendo que a suspensão de garantias deve ser temporária, não pode ser dirigida contra um indivíduo só, prioriza o respeito à direitos universais fundamentais que não podem ser suspensos ${ }^{423}$ e condiciona a autorização de suspensão de garantias ao julgamento da constitucionalidade ou anti-constitucionalidade por parte da SCJN.

A Lei Reguladora pretendida estabelecia como novidade, antes da sua revisão no Senado da República, a possibilidade de - suspensão temporal de direitos - em detrimento das garantias protegidas pelo artigo $29^{\circ}$ como invioláveis mesmo em um Estado de exceção constitucionalmente declarado, especificamente os direitos de liberdade de expressão, patrimoniais, manifestação, associação, circulação, crédito e direitos de autor. Em paralelo, acrescenta cenários $^{424}$ que possibilitariam a suspensão de garantias $^{425}$. O ativista e poeta Javier Sicilia remete em uma publicação titulada "Legalizar el Estado de excepción" 426 à questão da

\footnotetext{
${ }^{421}$ De Atenco a Atenquera, la represión y el engaño del peñismo - Jenaro VILLAMIL em Proceso, publicado em 21 de junho de 2016, disponível em: http://www.proceso.com.mx/444766/atenco-a-antequera-la-represionengano-del-penismo - acessado em junho de 2016.

${ }^{422}$ Artículo $29^{\circ}$ : "En los casos de invasión, perturbación grave de la paz pública, o de cualquier otro que ponga a la sociedad en grave peligro o conflicto, solamente el presidente de los Estados Unidos Mexicanos, con la aprobación del Congreso de la Unión (...) podrá restringir o suspender en todo el país o en lugar determinado el ejercicio de los derechos y las garantías que fuesen obstáculo para hacer frente, rápida y fácilmente a la situación; pero deberá hacerlo por un tiempo limitado."

423 Os direitos que não podem ser suspensos segundo o Artigo $29^{\circ}$ são: O direito à não discriminação, reconhecimento da personalidade jurídica, à vida, à integridade pessoal, à proteção da família, ao nome, à nacionalidade. Protege também os direitos da criança, a liberdade de crença religiosa, o princípio de legalidade e retroatividade, a proibição da pena de morte, a proibição da escravidão, a proibição da desaparição forçada e tortura.

424 Os cenários mencionados são: a) Naturais: terremotos, tempestades, furacões, explosões vulcânicas e epidemias; b) Revoltas internas de grande magnitude; c) Incursão de grupos armados internos; d) Grandes afetações à paz ou à estabilidade interna do próprio Estado; e) Crise econômica; f) Casos fortuitos: incêndios, acidentes nucleares ou ataques biológicos.

${ }^{425}$ Estado de excepción: derechos en riesgo - Editorial La Jornada, publicado em 30 de março de 2016, disponível em: http://www.jornada.unam.mx/2016/03/30/edito - acessado em junho de 2016.

${ }^{426}$ Legalizar el Estado de excepción - Javier SICILIA em Proceso, publicado em 13 de abril de 2016, disponível em: http://www.proceso.com.mx/436850/legalizar-el-estado-de-excepcion - acessado em junho de 2016.
} 
contradição essencial da dialética entre legalidade e Estado de exceção lembrando que este tipo de artigos constitucionais " [...] dan forma legal a lo que, al destruir cualquier legalidad, no puede tener forma legal, sino que ha permitido también la instauración de Estados totalitarios" e reafirma que, contudo, o Estado de exceção se instaurou de facto e sem decreto desde 2006 com o começo da guerra de Calderón e que foi apenas reforçado com Peña Nieto e, além do mais, "[...]no se ha dirigido, como lo muestra el ejemplo alemán, únicamente contra adversarios políticos y categorías enteras de ciudadanos contrarias o no asimilables a los intereses del sistema político", senão "contra la población entera".

Porém, o principal problema levantado em torno da lei reguladora do Artigo $29^{\circ}$ é a ambiguidade da mesma que lhe outorga poder excessivo ao Presidente da República para suspender constitucionalmente garantias individuais fundamentais como a associação, manifestação e circulação, por motivos altamente interpretáveis como uma "crise econômica". A intenção de criar uma lei reguladora deve ser precisamente criar regras e diretrizes de ação detalhadas para definir as possíveis ambiguidades que possam existir no artigo constitucional e assim evitar interpretações autoritárias ou incompetentes de um Artigo Constitucional que tem implicações diretas com garantias universais do cidadão. A Comisión Mexicana de Defensa y Promoción de los Derechos Humanos - CMDPDH estabelece uma serie de observações ${ }^{427}$ à lei reguladora do Artigo $29^{\circ}$, dentre elas, demanda a definição precisa dos supostos no artigo $2^{\circ}$ da Lei Reguladora sobre "perturbação grave da paz pública", "grave perigo" e "conflito" para outorgar certeza e delimitação, evitando definições vagas que permitam arbitrariedades.

A lei promovida por Peña Nieto pretendia fazer exatamente o oposto e, em um Estado como o mexicano que se encontra em condições particulares de violência generalizada e ataques contra a população civil por parte de agentes do narcotráfico e do Estado, o perigo é altíssimo. A ambiguidade e a interpretatividade da lei que regula a suspensão de garantias, em um contexto de decomposição social e legal que tem acontecido nos últimos 10 anos, representa o esvaziamento total do Estado de direito enfraquecido após anos de conflito e de tradição autoritária do PRI. Além do mais, segundo Sicilia ${ }^{428}$, é disfarçar ao Estado de exceção de facto como Estado de direito e de liberdades democráticas mediante uma Lei reguladora que faz todo menos regular. De esta forma, se lhe outorga um caráter e marco jurídico ao Estado de exceção

\footnotetext{
427 Observaciones al Dictamen aprobado por las Comisiones de Derechos Humanos, Justicia y Estudios Legislativos del Senado de la Republica de la iniciativa con proyecto de decreto por el que se expide la Ley Reglamentaria del Artículo 29 Constitucional en materia de suspensión de derechos humanos y sus garantías disponível em: http://cmdpdh.org/project/observaciones-art-29-constitucional/ - acessado em junho de 2016.

${ }^{428}$ Legalizar el Estado de excepción - Javier SICILIA. Op. Cit.
} 
e a bolha de exceção da lei se transforma em norma que acaba com o paradoxo da sua existência e se universaliza como paradigma de ação do Estado e não mais como um recurso de emergência contra o narcotráfico ou alteridades dissidentes. Isto faz que a população na sua totalidade fique em situação de vulnerabilidade - até mesmo a classe média que até hoje se acredita intocável e protegida - diante da crescente militarização da esfera pública, do abandono institucional e da nula representação política da população, isto é " [...] una nueva forma de totalitarismo, o por lo menos, su antecedente" ${ }^{429}$.

A conjunção da tentativa de estabelecer um marco jurídico débil e interpretável para fazer da suspensão de garantias um decreto corriqueiro, a pré-existência de facto de um Estado de exceção, a crescente militarização de todos os aspectos da vida pública em prol da segurança com a anuência da população civil e o agachamento das forças armadas, historicamente apolitizadas, diante do Presidente da República e o seu partido, apresentam um cenário alarmante que o escritor mexicano Fernando del Paso, ao receber o prémio Cervantes na cidade de Madri, chamou de "principio de un Estado totalitario que no podemos permitir 430". É inegável a crescente presença das forças armadas na vida pública e política da nação em alinhamento total com as políticas de segurança do regime priísta que levou aos emblemáticos casos de Tlatlaya e Ayotzinapa, entre outros. A letalidade virou parte essencial do agir das forças castrenses incentivado desde a parte alta do governo federal: a ordem é abater.

A letalidade extrema das forças armadas mexicanas não passou desapercebido para o jornal New York Times ${ }^{431}$ que afirma que, na guerra moderna, o normal é ferir ao inimigo. No México, aponta, a eficiência letal do exército é inédita e isto aponta à prevalência de execuções sumarias extrajudiciárias como a de Tlatlaya. A relação de feridos com mortos em conflitos modernos é de 4:1, afirma o jornal, enquanto no México é inverso: 1:8, isto é, um ferido por cada oito mortos em comparação com a média de um morto por quatro feridos. No caso da marinha mexicana é mais alarmante ao ter uma relação de 1:30 - trinta mortos a cada um ferido -.

O Exército e a Marinha, por sua vez, permanecem intocados como foi visto no caso de Tlatlaya e Ayotzinapa. O governo mexicano não apenas não consegue investigá-los, senão que não quer nem pretende. O México tem a caraterística, dentro da América Latina, de nunca ter sofrido um

\footnotetext{
${ }^{429}$ Ídem

${ }^{430}$ La Ley Atenco, "principio de un estado totalitario que no podemos permitir": Del Paso - Redacción Aristegui Noticias, publicado em 23 de abril de 2016, disponível em: http://aristeguinoticias.com/2304/mexico/la-leyatenco-principio-de-un-estado-totalitario-que-no-podemos-permitir-del-paso/ - acessado em junho de 2016.

${ }^{431}$ Mexican military runs up body count in drug war-Azam AHMED e Eric SCHMITT em The New York Times, publicado em 26 de maio de 2016; disponível em: http://www.nytimes.com/2016/05/27/world/americas/mexicanmilitarys-high-kill-rate-raises-human-rights-fears.html? r=0 - acessado em junho de 2016.
} 
golpe militar na época das ditaduras latino-americanas, situação que é perfeitamente lógica ao ter um partido autoritário que negocia e integra tudo, e as forças armadas não foram a exceção. Após a turbulência pós-revolucionária e a consolidação do regime na década de 60 e 70, as forças armadas permaneceriam apolíticas e protegidas em troca da autonomia total para o governo do PRI, um saindo na defesa do outro quando for preciso ${ }^{432}$, daí que até hoje não haja havido condenações para os participantes do Massacre de Tlatelolco em 1968 e o Massacre de Corpus Christi em 1971, ou a absolvição total dos militares participantes em Tlatlaya e a veemente negativa para investigar ao $27^{\circ}$ Batalhão de Iguala no caso Ayotzinapa.

Durante a redação das presentes considerações finais, o Estado mexicano invadiu o povoado de Nochixtlán no estado de Oaxaca no marco do conflito com a Coordinadora Nacional de Trabajadores de la Educación - CNTE e o Governo Federal pela implementação de uma reforma em matéria de educação. Foi um confronto que durou mais de 15 horas com a intenção de desbloquear a estrada que une a Cidade do México com a cidade de Oaxaca ${ }^{433}$. Participaram a Polícia Federal e a Gendarmaria Nacional - ambas as corporações já perfiladas decididamente como o braço armado e grupo de choque do Estado - que confrontaram aos habitantes do povoado e aos membros da CNTE. Os elementos da PF e da Gendarmaria, contrário ao que $a$ Comisión Nacional de Seguridad - CNS havia informado, encontravam-se armados e foram flagrados atirando contra os manifestantes ${ }^{434}$. O confronto deixou 23 detidos, 108 feridos ${ }^{435}$ (entre policiais e civis) e 8 assassinados por arma de fogo ${ }^{436}$.

Resulta evidente que o Estado agiu de maneira agressiva e desproporcionada contra um grupo dissidente pertencente às categorias sociais e raciais consideradas indesejáveis em um contexto de proliferação do crime organizado e do narcotráfico em simbiose com o Estado em processo de militarização. Estes são fatores que mantêm à nação afundada na pior crise da sua história

\footnotetext{
432 Ídem.

${ }^{433}$ De Atenco a Antequera, la represión y el engaño del peñismo - Jenaro Villamil em Proceso, publicado em 21 de junho de 2016, disponível em: http://www.proceso.com.mx/444766/atenco-a-antequera-la-represion-enganodel-penismo - acessado em junho de 2016.

${ }^{434}$ Armas usadas por policías en Nochixtlán, en poder de la PGR: CNS - Redacción Aristegui Noticias, publicado em 23 de junho de 2016, disponível em: http://aristeguinoticias.com/2306/mexico/armas-usadas-por-policias-ennochixtlan-en-poder-de-la-pgr-cns/ - acessado em junho de 2016.

435 Nochixtlán: 6 muertos y 108 heridos, tras choques entre PF y CNTE - Juan Omar FIERRO em Aristegui Noticias, publicado em 20 de junho de 2016, disponível em: http://aristeguinoticias.com/2006/mexico/oaxaca-6muertos-y-108-heridos-tras-choques-entre-pf-y-cnte/ - acessado em junho de 2016.

${ }^{436}$ Oficial: fueron ocho los muertos en Nochixtlán; ninguno era maestro - Redacción Aristegui Noticias, publicado em 20 de junho de 2016, disponível em: http://aristeguinoticias.com/2006/mexico/oficial-fueron-ocho-losmuertos-en-nochixtlan-ninguno-era-

maestro/?cx=004150719906283247468\%3Ajex9qrlcwyw\&cof=FORID\%3A11\&q=nochixtlan\&x=6\&y=8\# acessado em junho de 2016.
} 
segundo a fundação Open Society no seu informe titulado "Atrocidades Innegables:

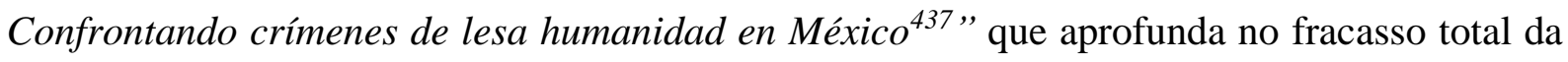
guerra contra as drogas, a sua perversão e posterior reinterpretação por parte do governo de Enrique Peña Nieto fazendo-a virar uma ferramenta de contenção e extermínio social de um Estado autoritário. O informe conclui que a crise de assassinatos, tortura e desaparições continua de forma mais severa após nove anos de guerra contra as drogas, tempo durante o qual tanto os cartéis como o Estado cometeram crimes e ataques contra a população civil de forma sistemática e generalizada e, por tanto "[...] existen bases para sostener que actores estatales y no estatales por igual han cometido crímenes contra la humanidad en México" ${ }^{438}$.

A crise atual e o futuro nos apresentam desafios monumentais que não são de rápida resolução ao estarem emanados de uma questão civilizatória primordial que nunca foi discutida e, pelo contrário, foi aprofundada durante séculos: a questão do Outro e a definição do indesejável. A questão do México contemporâneo não é mais do que a crise e o fracasso total do projeto civilizatório baseado na ideia da supremacia fundacional do europeu contra o índio conquistado. Há dois vícios principais que Javier Sicilia ${ }^{439}$ identifica: a) a dominação histórica de oligarquias antidemocráticas - das quais o PRI e a partidocracia no geral fazem parte - que dirigem ao país como se fosse a sua propriedade. Esta noção é sustentada pelos remanentes do binarismo primordial da conquista através de uma percepção perversamente racializada, ideologizada, politizada e economizada do desejável e do indesejável; e b) a crise civilizatória que alimenta e se alimenta do anterior e que produz o fracasso e a falência do Estado mexicano, ajoelhado perante as ideologias nacionalistas excludentes e homogeneizadoras, em um primeiro momento, e ao grande capital posteriormente.

Pelo anterior, se identificam quatro áreas críticas de análise sobre a problemática nacional: a) Educação, b) o PRI e as formas de organização priístas, c) militarização e d) corrupção.

Seguindo o anterior, um dos campos de ação prioritários é a SEP e a sua urgente e impostergável reforma profunda e absoluta. Esta instituição é, como o aparelho institucional estatal, um braço a mais ao serviço do antigo regime que foi projetado e implementado como parte essencial da maquinaria estatal do PRI para espalhar a ideologia nacionalista do partido, a história oficial da

\footnotetext{
437 Disponível no portal de Open Society Foundation em formato PDF: https://www.opensocietyfoundations.org/reports/undeniable-atrocities-confronting-crimes-against-humanitymexico/es - acessado em junho de 2016.

${ }^{438}$ Ídem, p. 166.

${ }^{439}$ Un nuevo proyecto de nación - Javier SICILIA em PROCESO, publicado em 18 de outubro de 2015, disponível em: http://www.proceso.com.mx/418428 - acessado em junho de 2016.
} 
nação e a perpetuação das estruturas que fazem de um cidadão alguém desejável ou indesejável. A SEP tem que ser dotada de autonomia em relação ao Estado e ao pensamento priísta sem cair no equivoco da privatização da educação pública, a qual deve continuar sendo laica, gratuita e obrigatória.

É importante considerar também a presencia constante, embora mutável, da face integradora e negociadora do partido da revolução e das denominadas - formas de organização priísta -, ou as organizações que funcionem seguindo a lógica caciquista do PRI - tais como a partidocracia no geral - e as organizações que sejam apêndices do mesmo enquistados em outros níveis de organização cidadã - tais como os sindicatos liderados por caciques do PRI ou empresas ao seu serviço como Televisa ${ }^{440}$, Sindicato Nacional de Trabajadores de la Educación - SNTE, Confederación de Trabajadores de México - CTM, Sindicato de Trabajadores Petroleros de la República Mexicana - STPRM, Sindicato de Trabajadores Ferrocarrileros de la República Mexicana - STFRM, Confederación Revolucionaria de Obreros y Campesinos - CROC e Sindicato Industrial de Trabajadores y Artistas de Televisión y Radio - SITATyR ${ }^{441}$, por citar alguns.

Se considera necessária a criação de alternativas de pensamento coletivo, cidadão e político que escapem ou rompam com o PRI, seu nacionalismo e a lógica de organização piramidal, integradora, negociadora e caciquista ${ }^{442}$. O caminho a seguir não é fácil nem simples se

\footnotetext{
${ }^{440}$ Grupo Televisa da família Azcárraga (hoje comandado por Emilio Azcárraga Jean) tem se caraterizado por ser o vozeiro oficial do PRI ao agir em favor de candidatos durante a época eleitoral (como feito com Peña Nieto) ou como jornal oficial (com a emblemática frase "Hoje foi um dia com muito sol" do apresentador Jacobo Zabludovzky após o Massacre de Tlatelolco em 1968 ou do ex-presidente do consorcio, Emilio Azcárraga Milmo, quem se declarou como "um soldado do PRI").

${ }^{441}$ Os líderes dos sindicatos são, ao mesmo tempo, afiliados ao PRI e ocupam posições políticas outorgadas pela via plurinominal, isto é: indicados diretamente sem necessidade de serem votados: 1) SNTE: Elba Esther Gordillo; atualmente em prisão por lavagem de dinheiro, já foi deputada e senadora federal pelo PRI; 2) STPRM: Carlos Romero Deschamps; atualmente senador federal pelo PRI; 3) STFRM: Víctor Félix Flores; deputado federal pelo PRI; 4) CTM: Joaquín Gamboa Pascoe (finado) e Carlos Aceves del Olmo, ambos ocuparam posições no senado e câmera de deputados no nível federal pelo PRI; 5) SITATyR: Patricio Flores Sandoval; deputado federal pelo PRI; 6) CROC: Isaías González Cuevas; senador federal pelo PRI.

${ }^{442}$ Em 2015, um grupo de catedráticos e investigadores do Consejo Nacional de Universitarios por una Nueva Estrategia de Desarrollo publicou um manifesto titulado "iReconstruyamos nuestra nacion!" (Reconstruamos a nossa nação!). Nele estabelecem oito cursos de ação em distintas áreas: 1) Economia; 2) Direitos econômicos, sociais e culturais; 3) Desenvolvimento sustentável regional e urbano; 4) Desenvolvimento econômico inclusivo, equitativo e sustentável; 5) Inserção digna e eficiente do país nos processos de globalização e regionalização; 6) Segurança pública e transparência na rendição de contas; 7) Estado de direito e construir a democracia; 8) Desenvolvimento e estado de bem-estar. - Consejo Nacional de Universitarios por una Nueva Estrategia de Desarrollo - http://www.consejonacionaldeuniversitarios.org.mx/ (Inacessível no momento da redação - Julho 2016) - ${ }^{442}$ Documento resgatado de La Jornada devido à inacessibilidade do portal do Consejo Nacional de Universitarios - Publicado em 28 de maio de 2015, disponível em: http://www.jornada.unam.mx/ultimas/2015/05/28/manifiesto-reconstruyamos-nuestra-nacion-

1750.html - acessado em julho de 2016.
} 
pretendemos agir de uma forma que seja percebida como democrática e, isto sem mencionar a dificuldade decorre da infiltração do PRI e da partidocracia em praticamente todas as instâncias institucionais, legislativas e de organização cidadã.

O terceiro ponto se refere ao combate à militarização da esfera pública e da noção de segurança. Para isto já foi mencionado que o primeiro passo é a mudança do discurso beligerante que Felipe Calderón usou como ferramenta de propaganda e autopublicidade. Falar de guerra e corriqueiramente ameaçar aos cartéis da droga com combate é luta fez que se armaram e se prepararam para, de fato, uma guerra. Isto não implica, claro, não combatê-los, senão simplesmente eliminar a via armada e fazê-lo através a da sua desarticulação econômica e territorial, isto é: a eliminação do mercado altamente lucrativo para o narcotráfico mediante a legalização individual de cada sustância em questão com a criação de políticas específicas para cada droga e mercado de consumo, em conjunto com a recuperação paulatina dos territórios de trânsito e distribuição mediante o estabelecimento de serviços básicos e de infraestrutura que facilite a recuperação dos territórios perdidos tanto físicos como da administração política estritamente por parte da população civil.

Por outro lado, deve-se considerar o caminho da desmilitarização tanto das táticas como do treinamento das corporações policiais não-militares como a Policia Federal e a Gendarmaria Nacional e a adopção de táticas e diretrizes de ação que visem a preservação da vida humana até o último recurso, o qual seria o uso da força letal. Retomando a posição do Relator Especial da ONU sobre execuções extrajudiciárias, sumarias ou arbitrarias, Christof Heyns, sobre a perpetuação da violência ao militarizar a segurança pública, resulta imperativo fomentar as capacidades das autoridades civis em matéria de investigação, processo penal e policiamento em labores de prevenção, investigação e condenação - nunca de uso da força letal - através da diminuição de efetivos militares nas ruas e o aumento de efetivos civis em conjunto com a criação de um marco jurídico forte para regular o uso da força visando proteger a vida humana até as últimas consequências ${ }^{443}$. Por outro lado, Heyns exorta energicamente a buscar a independência da PGR em relação ao Poder Executivo já que esta relação intima parcializa o agir da dependência e age como facilitador de possíveis crimes de Estado e desaparições forcadas $^{444}$.

\footnotetext{
${ }^{443}$ Relatório de Christof Heyns sobre a sua visita ao México em 2013 - Op. Cit. (pp. 8-9-10).

${ }^{444}$ Ídem; p. 21.
} 
O sugerido por Heyns seria voltar à normalidade do funcionamento de um Estado que se assume democrático e civil, portanto, a medida extraordinária e necessária seria a eliminação da premissa de que o narcotráfico, nos países latino-americanos, requer de medidas "excepcionais" para ser combatido. Esta premissa é apenas a justificativa geral para a instauração do Estado de exceção de facto, dispensa aos Estados Unidos da responsabilidade da violência e do tráfico de drogas e justifica a sua intervenção sob pretexto de segurança nacional (EMMERICH: 2015, p. 145). Para combater o anterior, o próprio Emmerich (2015, p. 145-146) estabelece umas diretrizes de mudanças paradigmáticas a partir de uma série de dicotomias:

a) O narcotráfico é um problema arraigadamente latino-americano $\rightarrow$ O narcotráfico é um problema derivado da demanda de drogas dos grandes centros de consumo mundial.

b) O narcotráfico é uma ameaça à segurança internacional e nacional $\rightarrow$ O narcotráfico é um problema de crime organizado próprio de sociedades desiguais, com falta de oportunidades de mobilidade social e com presença constante de forças militares e policiais do Estado.

c) A resolução do conflito é unicamente através da luta, do combate e da guerra $\rightarrow$ O uso do discurso beligerante é ineficaz e propicia a escalada da violência. A "luta" tem que vir de universos de análise e elaboração de políticas distintos à luta armada e à segurança nacional ou internacional.

d) Lutar mediante a implementação de acordos bilaterais entre os Estados Unidos e América Latina como o Plan Colombia ou a Iniciativa Mérida $\rightarrow$ Cooperar mediante a implementação de acordos aproveitando a existência de laços econômicos, políticos e culturais para impulsionar a integração latino-americana.

e) Estados Unidos como o eixo articulador e principal parceiro em toda política de luta contra o narcotráfico $\rightarrow \mathrm{O}$ problema é interno dada a magnitude da corrupção dentro das forças de segurança latino-americanas, as quais devem ser reformadas urgentemente. $\mathrm{O}$ apoio dos Estados Unidos não adianta se este problema persistir.

f) As polícias nacionais são corruptas, estão debilitadas e superadas pelo poder das armas e de cooptação do narcotráfico. É necessária a intervenção das forças Armadas $\rightarrow$ Distinção imperativa entre segurança interior e defesa nacional. As Forças Armadas não estão capacitadas para o policiamento interno, senão para a guerra.

E finalmente, a corrupção deve ser entendida como um mal sistémico do Estado mexicano e que este último depende dos atos de corrupção para funcionar em todos os níveis. Isto implica evidentemente que lutar contra este mal significará a intervenção do Estado através das suas 
instituições e agentes para impedir este combate. Como foi visto no caso da Ley 3 de 3, no qual o Estado mobilizou ao aparelho legislativo no Congresso Nacional para mutilar a iniciativa cidadã e criar uma lei “para o inglês ver". Portanto, é preciso falar da necessidade da criação de conselhos cidadãos autônomos com a jurisdição e atribuições legais necessárias para combater à corrupção em todos os níveis. Em paralelo e para isto funcionar, a independência e autonomia do Ministério Público e das agências de investigação são urgentes para conseguir um balanço de poder entre o Judiciário e o Poder Executivo. Isto significa destruir um dos códigos essenciais do PRI: a supremacia do Presidente da República.

Os Estados, disse Javier Sicilia ${ }^{445}$, enquanto construções humanas, são como nós: finitos. O Estado mexicano, se definido como um conjunto de instituições que estabelecem normas e regulam à sociedade, representando-a e velando pelos interesses da população, segundo o autor, está entrando não apenas em uma fase crítica, senão terminal e, assegura, o Estado tem a sua legitimidade desvalorizada e a legalidade sequestrada. A crise do Estado e da nação mexicana não encontrará solução se for procurada na disputa desgastada da "alternância" democrática própria de uma suposta vida política saudável, a questão é a inexistência sequer do conceito de democracia em grande parte da América Latina.

\footnotetext{
"Una crisis que a lo largo de las décadas ha ido erosionando la legitimidad hasta hacerla desaparecer de la vida institucional, no puede resolverse exclusivamente en el plano del derecho. Hipertrofiado hasta la médula, sus consecuencias - las vemos acrecentarse cada día - son la impunidad, la corrupción, el desprecio de la vida del ciudadano, la parálisis de la justicia, el caos, la violencia rampante y el sufrimiento indecible que produce en cada ser humano y que en México ya alcanza la categoría de crímenes de lesa humanidad". Javier Sicilia ${ }^{446}$.
}

A nação mexicana tem de ser repensada urgente e totalmente já que a permanência histórica dum projeto civilizatório apegado ao ocidente e à branquitude da minoria há levado ao México à pior crise da história. Os pontos anteriormente expostos são esboços de propostas feitas desde distintos frentes para articular os primeiros passos necessários para começar um novo caminho, daquilo que nós queremos ser e não ser como país e, como afirma Sicilia em outra publicação ${ }^{447}$, tem que ser feito na profundeza da nação e não nas estruturas erodidas e podres do Estado priísta

\footnotetext{
445 La agonía del Estado - Javier SICILIA em Proceso, publicado em 28 de maio de 2016, disponível em: http://www.proceso.com.mx/442022/la-agonia-del - acessado em julho de 2016.

446 Ídem.

${ }^{447}$ Un nuevo proyecto de nación - Javier SICILIA. Op.Cit.
} 
e da partidocracia e, portanto, seguindo as ideias do autor e tomando a liberdade de enriquecêlas, o labor tem que ser feito: 1) olhando para o passado da nação, para os seus povos originários e o que foi feito com eles, procurar a redenção própria assumindo a culpa da negação das civilizações originárias, devolvendo o roubado e reconhecendo o lugar que sempre lhes há correspondido para, de esta maneira, poder sequer começar a pensar em termos de futuro; 2) olhar para a periferia social dos nossos dias que a centralidade do Outro-desejável criou por consequência, já que talvez assim podamos sentir e entender, nem que seja um pouco, a dor que lhes há sido infligida durante os últimos anos; e 3) eliminar totalmente o discurso político desgastado; a substituição do pensamento priísta e da partidocracia tem que ser acompanhada da criação da nossa própria agenda política de nação, isto é: a urgente necessidade de criar uma nova Constituição Política e substituir a Carta de 1917.

\section{A escuridão do futuro em questão}

Não é apenas o México que se adentra na escuridão, senão que no mundo é possível apreciar um cada vez mais acelerado processo de decomposição, de sublevação e de radicalização em distintas frentes. Resulta cada vez mais difícil negar a convulsão global da qual a nossa geração é testemunha e partícipe. A rebelião das massas sob o sistema hegemônico neoliberal não é apenas inegável, senão que é absolutamente perceptível e não querer enxerga-lo significaria a repetição dos vícios históricos de outras épocas, como ocorre no Brasil com o clamor de setores da sociedade pela volta da ditadura militar o surgimento de fascismos messiânicos abraçados pela população em outras latitudes. O capitalismo neoliberal, aquele que tinha prometido abundância que viria da cima e permearia nas parcelas baixas, hoje concentra mais da metade da riqueza do planeta em apenas $1 \%$ da população ${ }^{448}$. As ideologias sofrem o embate de

\footnotetext{
${ }^{448}$ Riqueza global estará solo en $1 \%$ de la población en 2016 - Redacción FORBES, publicado em 19 de janeiro de 2015, disponível em: http://www.forbes.com.mx/riqueza-global-estara-en-solo-1-de-la-poblacion-en-2016/ acessado em julho de 2016.
} 
políticos e partidos produtores de retórica esvaziada de significado para perpetuar no poder à partidocracia e à classe política oportunista das nossas nações ${ }^{449}$.

O crescente caos no oriente médio; o surgimento do Estado Islâmico e a radicalização de certos setores do mundo islâmico; destruição da Síria e o êxodo de refugiados para a Europa; os ataques terroristas de Paris e Bélgica; o terror de Boko Haram na Nigéria; o golpe de Estado no Brasil e a radicalização da extrema direita liderada por pessoas ignominias; o crescente assenso de Donald Trump nos Estados Unidos com um discurso abertamente xenofóbico e de apologia ao ódio e à violência em conjunto com o fortalecimento dos grupos de supremacia branca no espaço público em distintas nações, tanto americanas como europeias; o extermínio das alteridades dissidentes no México, a militarização da segurança e da vida pública e a imposição pela via do sangue de reformas estruturais tecnocráticas; o ataque à comunidade LGBT em Orlando, o aumento da intensidade do discurso homofóbico, a defesa fundamentalista da chamada "família tradicional” e a incitação ao ódio por parte de alguns líderes da Igreja Católica contra a comunidade gay. Todo o anterior não pode ser considerado como casos isolados um do outro, senão que todos são parte do que Pablo Gentili denominaria como o - ressurgimento do fascismo social ${ }^{450}$ - ao se referir ao exercício evidente de machismo, misoginia, racismo e nacionalismo radical no processo de impeachment de Dilma Rousseff. Fascismo, uma ideologia que levou à aniquilação de 70 milhões de pessoas ${ }^{451}$.

A maneira de reflexão final, resgato a ponderação de William Davies ${ }^{452}$ quem afirma que é preciso pensar na corrupção da nossa felicidade, a qual foi transformada em um produto a mais e em algo que podemos escolher, ou bem, comprar através de produtos anunciados ad nauseam como portadores de algo que é essencialmente nosso, mas que nos foi sequestrado, industrializado e revendido. Somos doutrinados desde a nossa infância como o único meio para chegar a uma felicidade individual cujas caraterísticas devem ser compartilhadas por todos onde não se admitem diferenças ou alternativas.

Isto não é mais do que o "núcleo do pensamento neoliberal" em palavras de Davies. A crença de que todas as perguntas sobre a organização político-econômica já foram respondidas e que

\footnotetext{
${ }^{449}$ La rebelión de las masas bajo el capitalismo - Sabina BERMAN, em Proceso, publicado em 30 de abril de 2016, disponível em: http://www.proceso.com.mx/438912/la-rebelion-las-masas-bajo-caitalismo - acessado em julho de 2016.

${ }^{450}$ Hablemos del golpe en Brasil, hijo - Pablo Gentili. Op. Cit.

${ }^{451}$ World War II statistics - disponível em: http://www.secondworldwarhistory.com/world-war-2-statistics.asp acessado em outubro de 2016.

${ }^{452}$ La corrupción de la felicidad - William DAVIES em Horizontal, publicado em 8 de setembro de 2015, disponível em: http://horizontal.mx/la-corrupcion-de-la-felicidad/ - acessado em julho de 2016.
} 
resta apenas uma única via e um único listado de regras, reduzindo o debate democrático a ser apenas uma dadiva que o neoliberalismo nos outorga e não uma ferramenta de mudança paradigmática. As implicações individuais de este pensamento são graves como afirma o autor já que ao capitalismo liberal ser imutável para se adequar às necessidades humanas, somos nós os que temos que mudar para adequar-nos ao capitalismo. Portanto mudamos a nossa ideia de felicidade e os meios para alcançá-la e, caso o consigamos, não será mais do que uma felicidade imposta. O nosso futuro e a nossa felicidade, como indivíduos tanto como sociedade, devem ser uma produção autentica feita possível apenas pelas regras do jogo que nós escolhamos e que nós estabeleçamos para a vida individual e coletiva.

Porém, sem querer dar lugar ao pessimismo mais avassalador, o futuro em questão é incerto e, nas palavras de Roger Bartra (2014), o único que é perceptível é a sombra ou sombras que esse futuro projeta sobre o nosso presente. São sombras de decadência que “[...] enfrentan a la humanidad a retos intelectuales para los cuales el organismo, lleno de angustia, no está preparado" (BARTRA: 2014, p. 13), isto em ação conjunta com as sombras que o próprio passado projeta sobre nós. No entanto, não podemos fazer mais do que nos adentrarmos nas sombras que o futuro projeta se temos a pretensão de esboçar tentativas de mudança.

Como já dizia o poeta galês Dylan Thomas ${ }^{453}$ : "Não entres docilmente nessa boa noite (...) enfurece diante da morte da luz". A nossa geração não entrará tranquila nessa escuridão.

453 "Do not go gentle into that good night" - Dylan Thomas - 1952. 


\section{ANEXOS}

ANEXO 1 : LISTA DE CASTAS DA NOVA ESPANHA

\begin{tabular}{|c|c|c|c|c|c|}
\hline $\mathrm{DE}$ & $\mathrm{COM}$ & GRUPO & $\mathrm{DE}$ & $\mathrm{COM}$ & GRUPO \\
\hline Espanhol & Índia & Mestico & Calpamulato & Cambuja & Tente en el aire \\
\hline Espanhol & Mestica & Castico & Tente en el aire & Mulata & No te entiendo \\
\hline Espanhol & Negra & Mulato & Barnocino & Mulata & Coyote \\
\hline Espanhol & Mulata & Morisco & No te entiendo & India & Torna atrás \\
\hline Espanhol & Morisca & $\begin{array}{l}\text { Albino ou } \\
\text { Chino }\end{array}$ & Albarazado & Mestica & Barnocino \\
\hline Espanhol & China & Salta pa' tras & Indio & Mestica & Coyote \\
\hline Indio & Salta pa' tras & Lobo & Coyote & India & Chamizo \\
\hline Lobo & China & Jíbaro & Chamizo & Mestica & Ahí te estás \\
\hline Lobo & India & Zambaigo & Negro & India & Jaracho \\
\hline Zambaigo & India & Cambujo & Indio & Negra & Zambo \\
\hline Zambaigo & Loba & Calpamulato & Negro & Zamba & Zambo preto \\
\hline Cambujo & Mulata & Albarazado & Blanco & Mulata & $\begin{array}{l}\text { Tercerón } \\
\text { Cuarterón } \\
\text { Cuatralvo }\end{array}$ \\
\hline
\end{tabular}

Fonte: $\underline{\text { http://www.mflor.mx/materias/mexico/castas.html }}$

\section{ANEXO 2 : SENTIMENTOS DA NAÇÃO}

1.- Que a América é livre e independente da Espanha e de toda outra Nação, Governo ou Monarquia, e que assim se sancione, dando ao mundo os motivos.

2.- Que a religião católica seja a única, sem tolerância de outra.

3.- Que todos os seus ministros se sustentem de todos e apenas dos dízimos e primícias, e o povo não tenha que pagar mais gratificações que as da sua devoção e oferenda.

4.- Que o dogma seja sustentado pela hierarquia da Igreja, que são o Papa, os Bispos, os Curas, porque deve-se arrancar toda planta que Deus não plantou; omnis plantatis quam non plantabit Pater meus Celestis Cradicabitur. Mat. Cap. XV:

5.- Que a soberania dimana imediatamente do Povo, o que requer apenas depositá-la no Supremo Congresso Nacional Americano, composto de representantes das províncias de números. 
6.- Que os Poderes Legislativo, Executivo e Judiciário estejam divididos nos corpos compatíveis para exercê-los.

7.- Que funcionarão quatro anos os vogais, alternando-se, saindo os mais antigos para que ocupem o lugar os novos eleitos.

8.- A dotação dos vogais, será uma côngrua suficiente e não supérflua, e não passará por enquanto de oito mil pesos.

9.- Que os empregos apenas os americanos os obtenham.

10.- Que não se admitam estrangeiros, se não são artesãos capazes de instruir livres de toda suspeita.

11.- Que os Estados mudam costumes e, por conseguinte, a Pátria não será totalmente livre e nossa enquanto não se reforme o Governo, abatendo o tirânico, substituindo o liberal, e igualmente jogando fora do nosso solo ao inimigo espanhol, que tanto há se declarado contra a nossa Pátria.

12.- Que como a boa lei superior a todo homem, a que dite o nosso Congresso devem ser tais, que obriguem a constância e patriotismo, moderem a opulência e a indigência, e de tal sorte se aumente o jornal do pobre, que melhore seus costumes, afastando a ignorância, a rapinha e o furto.

13.- Que as leis gerais compreendam a todos, sem exceção de corpos privilegiados; e que estes o sejam somente em quanto ao uso do seu ministério.

14.- Que para ditar uma lei se faça junta de sábios no número possível, para que proceda com mais acerto e exonere de alguns cargos que pudessem resulta-lhes.

15.- Que a escravidão se proscreva para sempre, e o mesmo a distinção de castas, ficando todos iguais, e somente distinguirá a um americano do outro o vício e a virtude.

16.- Que nossos portos se franqueiem às nações estrangeiras amigas, mas que estas não se internem ao Reino por mais amigas que sejam, e somente haverá portos sinalizados para o efeito, proibindo o desembarque em todos os demais, sinalizando o dez por cento.

17.- Que cada um se lhe guardem as suas propriedades e se respeite na sua casa como em um asilo sagrado, sinalizando penas aos infratores.

18.- Que na nova legislação não se admita a tortura. 
19.- Que na mesma se estabeleça por Lei Constitucional a celebração do 12 de dezembro em todos os povos, dedicado à Padroeira da nossa Liberdade, Maria Santíssima de Guadalupe, encarregando a todos os povos, a devoção mensal.

20.- Que as tropas estrangeiras ou de outro Reino não pisem o nosso solo, e se for em ajuda, não estarão no mesmo lugar da Suprema Junta.

21.- Que não façam expedições fora dos limites do Reino, especialmente ultramarinas; mas (se autorizam as) que não são de esta classe, para propagar a fé aos nossos irmãos de Terra dentro. 22.- Que acabe a infinidade de tributos, peitos e imposições que nos agoniam, e se sinalize a cada indivíduo um cinco por cento de sementes e demais efeitos ou outra carga igual, ligeira, que não oprima tanto, como a Alcabala, o Estanco, o Tributo e outros; pois com esta ligeira contribuição, e a boa administração dos bens confiscados ao inimigo, poderá levar o peso da guerra e honorários de empregados.

23.- Que igualmente se solenize o dia 16 de setembro todos os anos, como o dia do aniversário em que se levantou a voz da Independência e a nossa santa Liberdade começou, pois nesse dia foi quando se descolaram os lábios da Nação para reclamar seus direitos com a espada na mão para ser escutada; lembrando sempre o mérito do grande herói, o senhor Dn. Miguel Hidalgo e o seu companheiro Dn. Ignacio Allende. 
ANEXO 3 : ESCALAS DO NARCOTRÁFICO

NARCO

\section{LOCAL}

REGIONAL

NACIONAL

MUNDIAL

\begin{tabular}{|c|c|c|c|c|}
\hline $\begin{array}{l}\text { Mecanismos } \\
\text { estruturais de } \\
\text { poder }\end{array}$ & Violência e coerção & $\begin{array}{l}\text { Infiltração e } \\
\text { cooptação dos } \\
\text { governos locais }\end{array}$ & $\begin{array}{l}\text { Corrupção e } \\
\text { infiltração das } \\
\text { instituições }\end{array}$ & $\begin{array}{l}\text { Relação: produção- } \\
\text { tráfico-consumo }\end{array}$ \\
\hline Formas de direito & $\begin{array}{l}\text { Uso do monopólio } \\
\text { da violência }\end{array}$ & $\begin{array}{l}\text { Lealdades e trocas } \\
\text { de favores políticos }\end{array}$ & $\begin{array}{l}\text { Negociação da lei, } \\
\text { dominação e } \\
\text { bloqueio de } \\
\text { instituições }\end{array}$ & $\begin{array}{l}\text { Negociação dentro } \\
\text { da economia } \\
\text { mundial }\end{array}$ \\
\hline $\begin{array}{c}\text { Formas de } \\
\text { racionalidade }\end{array}$ & $\begin{array}{l}\text { Monopólio da } \\
\text { produção }\end{array}$ & $\begin{array}{l}\text { Articulação dos } \\
\text { comandos de } \\
\text { produção locais }\end{array}$ & $\begin{array}{l}\text { Criar uma simbiose } \\
\text { com o Estado }\end{array}$ & $\begin{array}{l}\text { Circulação da } \\
\text { mercadoria e do } \\
\text { capital }\end{array}$ \\
\hline $\begin{array}{l}\text { Instituições } \\
\text { privilegiadas }\end{array}$ & $\begin{array}{l}\text { Dominação } \\
\text { violenta }\end{array}$ & $\begin{array}{l}\text { Parentesco } \\
\text { hierárquico / } \\
\text { lealdades }\end{array}$ & NarcoEstado & $\begin{array}{l}\text { Organizações } \\
\text { Internacionais }\end{array}$ \\
\hline $\begin{array}{c}\text { Unidades de } \\
\text { prática social } \\
\text { (agentes/atores) }\end{array}$ & $\begin{array}{l}\text { Comandos locais, } \\
\text { traficantes e } \\
\text { camponeses }\end{array}$ & $\begin{array}{l}\text { Cartel - Governos } \\
\text { locais }\end{array}$ & $\begin{array}{l}\text { Capos/cartéis, } \\
\text { funcionários } \\
\text { públicos/Estado }\end{array}$ & $\begin{array}{l}\text { Redes } \\
\text { transnacionais - } \\
\text { grandes capos - } \\
\text { empresários }\end{array}$ \\
\hline
\end{tabular}


ANEXO 4 : GEOGRAFIA FÍSICA DO TERRITÓRIO MEXICANO

Fonte: http://sinaloamx.com/mapas-de-sinaloa-mexico-relieve-del-pais/

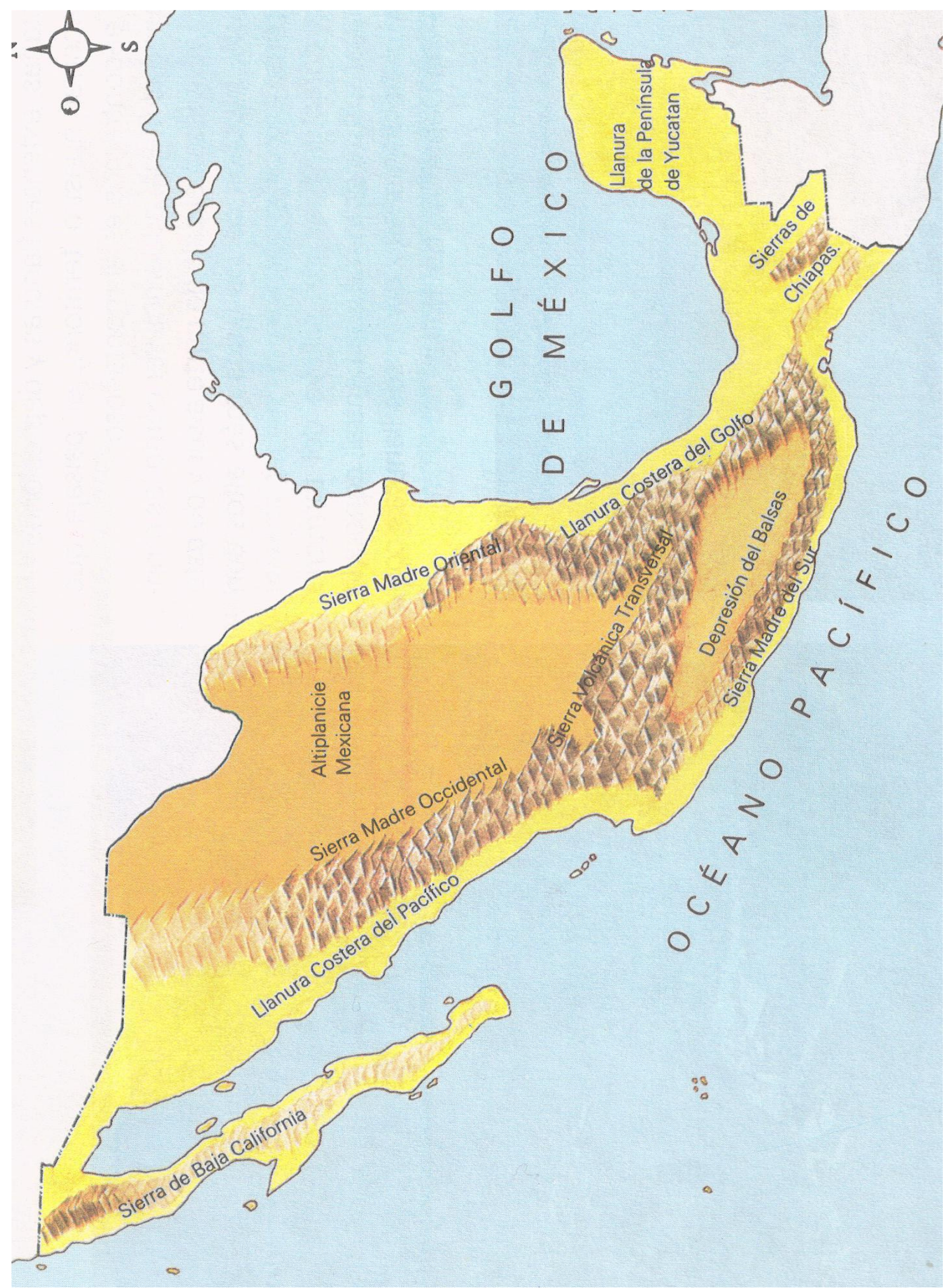




\section{ANEXO 5 : GEOGRAFIA POLÍTICA DO MÉXICO}

Fonte: http://www.mapacarreteras.com/uploads/mapas/61-mapa-politico-mexico.jpg

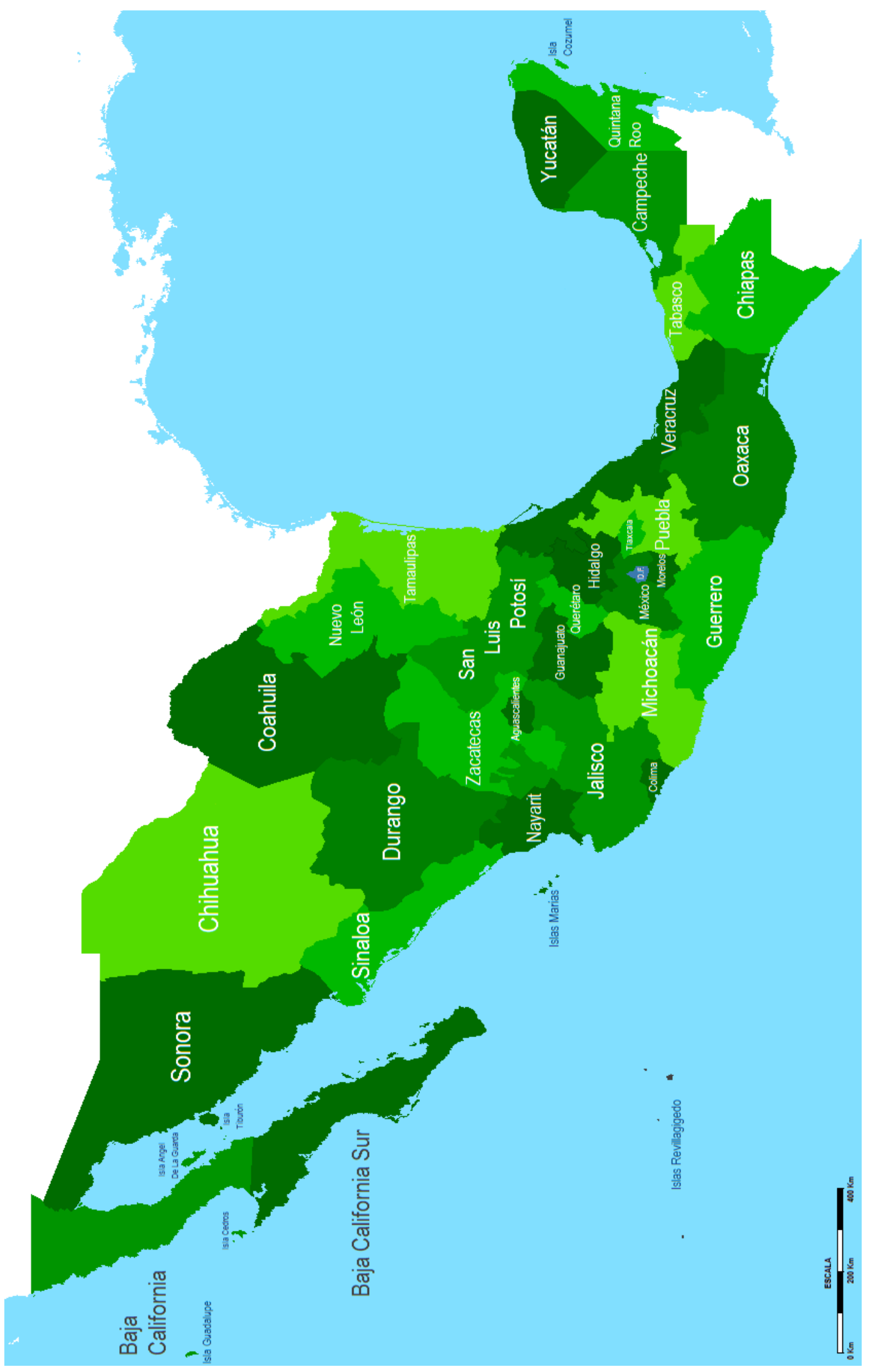




\section{BIBLIOGRAFIA}

AGAMBEN, G. 2005. State of exception. Chicago/Londres.: The University of Chicago Press.

BARRA. A. 2015. Políticas de drogas en América Latina: obstáculos y próximos pasos. Revista Nueva Sociedad, (255).

BARTRA, R. 2013. Territorios del terror y la otredad. México.: Fondo de Cultura Económica. 2014. La sombra del futuro. México.: Fondo de Cultura Económica.

BATAILLON, G. 2015. Narcotráfico y corrupción: las formas de violencia en México en el siglo XXI. Revista Nueva Sociedad, (255).

BERECIARTU, G.J. 1988. Contra el estado-nación. En torno al hecho y la cuestión nacional. Madrid: Siglo XXI Editores.

BOERSNER, D. 1996. Relaciones Internacionales de América Latina, Caracas.: Nueva Sociedad.

BONFIL BATALLA, G. 1990. México profundo: Una civilización negada. México, D.F.: Grijalbo.

BOURDIEU, P. 2000. La dominación masculina. Barcelona.: Editorial Anagrama. 2002. La distinción. México, D.F.: Taurus.

CASTRO, I.E., COSTA GOMES, P.C., LOBATO CORRÊA, R. 1995. Geografia: conceitos e temas. Rio de Janeiro.: Bertrand Brasil.

CLAUSEWITZ, C. 1996. Da guerra. Brasil: WMF Martins Fontes.

COSTA, W.M. 1992. Geografia política e geopolítica: Discursos sobre o territorio e o poder. São Paulo: Hucitec.

CRIADO, E.M. 2009. Habitus. Diccionario crítico de ciencias sociales. Terminología Científico-Social. Madrid-México.: Editorial Plaza y Valdés.

DALIO, M., ECCLES-WILlIAMS, P., NAKANDACARE, L. e RAMNAUTH, T. 2012. Narcoterrorismo en América Latina. Cuestión del mejor ser. Grupo de Estudios Internacionales Contemporáneos. Córdoba - AR.

DE LAS CASAS, B. 2005. Brevísima relación de la destrucción de las Indias. México, D.F.: Distribuciones Fontamara.

EMMERICH, N. 2014. Los medios de comunicación y el uso político del lenguaje. Más Poder Local, (20).

2015. Geopolítica del narcotráfico en América Latina. Toluca.: Instituto de Administración Pública del Estado de México, A.C.

GAMA, A. 1998. Escalas, representações e ação social. Lisboa.: Cadernos de Geografia, (17). 
GEREMIA, V., SAURI GARCÍA, J (COORD.). 2012. La infancia cuenta en México 2012: Desafíos actuales para la garantía de los derechos de la infancia. Análisis del marco legal mexicano. México: Red por los Derechos de la Infancia en México.

GOHN, M.G. 2000. Teorias dos movimentos sociais. São Paulo.: Loyola.

IBÁÑEZ DE NOVION, M.L.J. 2009. Las últimas fronteras del sistema capitalista: Hegemonía, integración económica y seguridad en las Américas. La Amazonia en cuestión. Universidad Nacional Autónoma de México.

KNIGHT, A. 2010. La Revolución Mexicana. México, D.F.: Fondo de Cultura Económica.

KUNHAVALIK, J.P. História do pensamento político: metodologia e analise. Os militares e o conceito de nacionalismo: Disputas retóricas na década de 1950 e início dos anos 1960. Universidade Federal de Santa Catarina. Pp. 24-33.

LABROUSSE, A. 2006. Geopolítica das drogas. São Paulo.: Desatino.

LACOSTE, Y. 1993. A geografia - isso serve, em primeiro lugar, para fazer a guerra. Campinas.: Papirus.

LINTON, M. 2015. La guerra contra las drogas: de Richard Nixon a Barack Obama. Revista Nueva Sociedad: Democracia y Política en América Latina, (255).

LOPES SOUZA, M. 1995. O território: sobre espaço e poder, autonomia e desenvolvimento. Em: Iná Elias Castro et al. Geografia: conceitos e temas. Rio de Janeiro: Bertrand Brasil.

MANN, C. 2002. 1491. The Atlantic Monthly.

MARIÁTEGUI, J.C. 2007. 7 ensayos de interpretación de la realidad peruana. Caracas.: Fundación Biblioteca Ayacucho.

MARQUES PEREIRA DOS ANJOS, D. 2015. Votán Zapata contra a Besta-fera. Escritos do EZLN contra o capitalismo no México. Universidade Estadual Paulista.

MESSARI, N. 2004. Existe um novo cenário de segurança internacional?. América latina y el (des)orden global. Pp. 131-149. Buenos Aires.: CLACSO.

O’FARRIL, I.L. 2010. Nacionalismo mexicano, algunas aproximaciones. Athenea Digital, (19), pp. 213-225.

PAZ, O. 1999. El laberinto de la soledad. México.: Fondo de Cultura Económica.

RINCÓN, O. 2015. Amamos a Pablo, odiamos a los políticos. Las repercusiones de Escobar, el patrón del mal. Revista Nueva Sociedad, (255).

SALMERÓN SANGINES, P.A. 1999. La construcción del partido de la revolución (1928-1946). Universidad Nacional Autónoma de México.

SANTANA, A. 1999. A globalização do narcotráfico. Revista Brasileira de Política Internacional, 42(2). Pp. 99-116.

2012. El narcotráfico en América Latina. México, D.F.: Siglo XXI Editores.

SIEDER, R., SIERRA, M.T. 2015 Ayotzinapa y la crisis del Estado mexicano: un espacio de reflexión colectiva ante la emergencia nacional. Ichan Tecolotl: La casa del tecolote, (293).

SILVA, C.T. 2009. Relatos de um certo ocidente: O indigenismo como orientalismo à americana. Revista de Estudos e Pesquisas sobre as Américas, 3(1). 
2015. Situações coloniais, pluralismo étnico e desafios da autonomia indígena na América Latina. Manuscrito.

SKINNER, Q. 2002. Visions of politics: regarding method. United Kingdom.: Cambridge University Press, vol.1.

SOBERÓN, R. 2011. Las tendencias del narcotráfico en América latina. Rebelión, (464).

TODOROV, T. 2003. A conquista da América: a questão do outro. São Paulo.: Martins Fontes.

VALDÉS, C. 2012. La simulación de la democracia. Voz de la tribu, (5), 13-19.: Universidad Autónoma del Estado de Morelos.

VASCONCELOS, J. 1925. La raza cósmica. Madrid.: Agencia Mundial de Librerías.

VERGARA, E. 2015. Prevención y uso de drogas: la urgencia de pensar nuevos paradigmas. Revista Nueva Sociedad, (255).

VISENTINI, J.W. 2009. O que é geopolítica? E geografia política? Resgatado de: http://www.geocritica.com.br/geopolitica.htm

WOLF, E.R. 1987. Europa y la gente sin historia. México, D.F.: Fondo de Cultura Económica.

ZEA, L. 1976. El pensamiento latinoamericano. México, D.F.: Editorial Pormaca. 